UNIVERSIDADE DE SÃO PAULO

INSTITUTO DE GEOCIÊNCIAS

\title{
CARACTERIZAÇÃO GEOMECÂNICA DE UM REJEITO DE MINERAÇÃO DE BAUXITA
}

\section{CARLA PALOMINO TINOCO}

Orientador: Prof. Dr. Fernando Antônio Medeiros Marinho

Dissertação de mestrado

$N^{\circ} 785$

COMISSÃO JULGADORA

Dr. Fernando Antônio Medeiros Marinho

Dr. Edilson Pissato

Dr. Heraldo Luiz Giacheti

Dr. Lúcio Flávio de Souza Villar

SÃO PAULO

2017 


\section{CARACTERIZAÇÃO GEOMECÂNICA DE UM REJEITO DE MINERAÇÃO DE BAUXITA}

Dissertação apresentada ao Instituto de Geociências da Universidade de São Paulo para obtenção do título de mestre em Ciências.

Área de concentração: Recursos Minerais e Hidrogeologia.

Orientador: Prof. Dr. Fernando Antônio Medeiros Marinho.

\section{São Paulo}


Autorizo a reprodução e divulgação total ou parcial deste trabalho, por qualquer meio convencional ou eletrônico, para fins de estudo e pesquisa, desde que citada a fonte

Ficha catalográfica preparada pelo Serviço de Biblioteca e Documentação do Instituto de Geociências da Universidade de São Paulo

Palomino Tinoco, Carla

Caracterização geomecânica de um rejeito de mineração de bauxita. - São Paulo, 2017.

$147 \mathrm{p}$.

Dissertação (Mestrado): IGc/USP

Orient.: Marinho, Fernando Antônio Medeiros

1. Bauxita 2. Rejeitos de mineração 3. Resistência ao cisalhamento 4. Caracterização geomecânica I. Título 
Para mis papitos y mis hermanas adoradas. 
Tudo passa -sofrimento, dor, sangue, fome, peste. A espada também passará, mas as estrelas ainda permanecerão quando as sombras de nossa presença e nossos feitos se tiverem desvanecido da Terra. Não há homem que não saiba disso. Por que então não voltamos nossos olhos para as estrelas? Por quê?

Mikhail Bulgakov, O exército branco

The shortest answer is doing the thing.

Ernest Hemingway 


\section{AGRADECIMENTOS}

Agradeço profundamente às três mulheres que sempre me incentivaram e apoiaram nas decisões que tomei. Às três mulheres que são meu orgulho e inspiração, minha mãe Maria Tinoco e minhas irmãs, Sora e Susan.

Ao meu gordinho, meu pai Victor Palomino, quem com seu bom humor, sábios conselhos e positivismo me faz ver o lado bom das situações.

Agradeço sinceramente ao meu orientador Prof. Dr. Fernando A. M. Marinho, professor que admiro muito pela simplicidade, simpatia e caráter, quem me deu uma segunda oportunidade de poder realizar o mestrado. Quero Ihe agradecer pela confiança, sugestões, correções e infinita paciência.

Ao Bruno Stefani pelo apoio, paciência e carinho. Obrigada pelos seus conselhos, sugestões de melhoria e organização relacionados com o mestrado e lado pessoal também.

Ao futuro engenheiro Robert Mendoza pela sua amizade, treinamento e "carnecitas" do ensaio triaxial.

Aos meus amigos do laboratório de mecânica de solos da Escola Politécnica, meus queridos: Val Silva, Joaquim Costa, Bernardo Jimenez, Edy Tejeda; especialmente ao Antônio Heitzmann, pelas conversas, orientações e ensinamentos.

Ao geólogo Paulo Camargo pela elaboração dos mapas geológicos.

Aos professores: Dr. Edison Pissato e Dr. José Nader pelas sugestões para melhoria da dissertação.

À professora: Dra. Heloísa Gonçalves Silva, por permitir a realização dos ensaios de caracterização geotécnica no laboratorio de mecânica de solos da Escola Politécnica.

Aos professores da Poli-Minas: Dr. Giorgio de Tomi e Dr. Arthur Chaves, pela ajuda na obtenção do material de estudo. A Dra. Carina Ulsen pelo fornecimento das análises de difratometria e fluorescência de raios x. A Dra. Eliana Mano pelas sugestões para a caracterização mineralógica das amostras.

À Empresa Votorantim Metais pelo grande apoio e fornecimento das amostras para o desenvolvimento desta pesquisa; principalmente aos engenheiros: Christian Fonseca, Caio van Deursen, Everton Reis que gentilmente me receberam na Usina Miraí. Aos engenheiros: Ricardo Vinhal, Nilson e Caetano por me deixarem conhecer a unidade de Itamarati.

A CAPES pelo auxílio financeiro para a realização desta pesquisa 


\section{RESUMO}

PALOMINO, C.T. 2017. Caracterização geomecânica de um rejeito de mineração de bauxita, 130p.

A demanda global por metais vem crescendo de forma de intensa. Este interesse comercial tem incrementado a quantidade de rejeitos produzidos na extração e/ou no beneficiamento dos minerais dos quais os metais são extraídos. Este aumento de demanda faz com que áreas menos ricas em minérios sejam viabilizadas economicamente, gerando assim mais rejeitos. A disposição destes rejeitos requer barragens de rejeitos de grandes dimensões as quais por sua vez exigem cuidados especiais sob o ponto de vista geotécnico e ambiental. Desta forma a utilização de rejeito como material de construção de aterros minimizaria os volumes das barragens de rejeito. Para que se possa fazer uso geotécnico dos rejeitos de qualquer processo de mineração é necessária a determinação de parâmetros geotécnicos que permitam análises de estabilidade, fluxo e compressibilidade, de modo a garantir a segurança e eficiência do seu uso. No presente estudo é investigado o comportamento geomecânico de três amostras de rejeito de mineração de bauxita, coletados em diferentes locais na usina de Miraí, MG. Para isto o rejeito foi caracterizado quanto a natureza geotécnica, avaliando-se o seu comportamento dentro de algumas condições de compactação. Os estudos envolveram a determinação do comportamento do material em ensaios triaxiais anisotrópicos não drenados, sob condições estáticas. O objetivo do presente estudo é definir as características geomecânicas do rejeito de bauxita de Miraí de modo que se possa definir, de forma segura, a sua utilização como material de aterro. Os resultados indicam que as restrições ao uso dos materiais estão relacionadas ao teor de umidade usado para compactação e que o material quando moldado na condição de umidade ótima, sob o ponto de vista geotécnico, possui bom potencial para ser utilizado como material de aterros compactados.

Palavras-chave: Bauxita. Rejeitos de Mineração. Resistência ao cisalhamento. Caracterização geomecânica. 


\section{ABSTRACT}

PALOMINO, C.T. 2017. Geomechanical characterization of a bauxite mining tailings, 130p.

The global demand for metals has grown intensely. This commercial interest has increased the amount of tailings produced in the extraction and/or processing of minerals from which metals are extracted. This increase in demand causes less mineral rich areas are economically feasible, thus generating more tailings. The disposal of tailings requires large tailings dams, which in turn require special care from geotechnical and environmental aspects. Thus, the use of waste as landfill construction material would minimize the volumes of tailings dams. To make the waste useable from a geotechnical point of view it is necessary to determine geotechnical parameters that allow analysis of stability, flow and compressibility, to ensure the safety and efficiency of its use. In this study the geomechanical behavior of three samples of bauxite mining tailing, collected at different locations from Miraí plant, Minas Gerais, is defined. This bauxite tailing was characterized in terms of geotechnical nature, evaluating its behavior in some specific compaction conditions. The studies involved the determination of material behavior at CAU triaxial test, under static conditions. The objective of the present study is to define the geomechanical characteristics of Miraí bauxite tailings so that their use as a landfill material can be safely defined. The results indicate that the restrictions on the use of materials are related to the moisture content used for compaction and that the material when molded in the optimum geotechnical wet condition has good potential to be used as compacted landfill material. 


\section{SUMÁRIO}

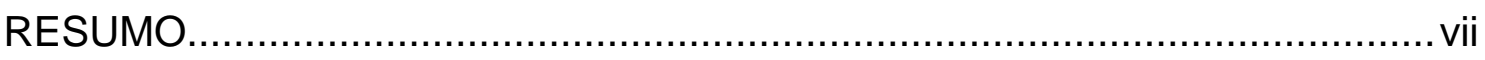

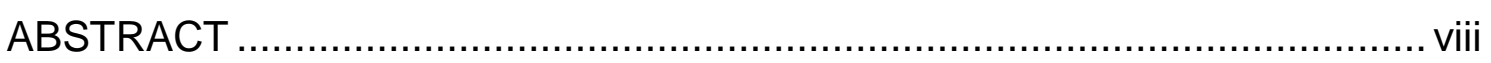

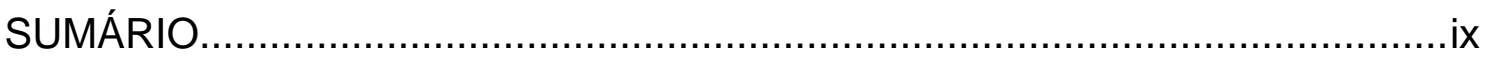

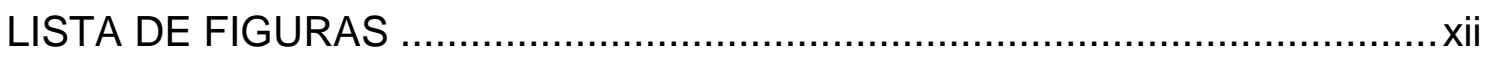

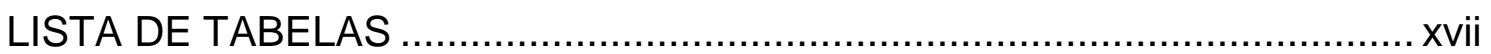

LISTA DE ABREVIATURAS E SIGLAS .................................................. xviii

1 INTRODUÇÃO

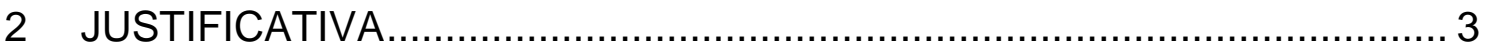

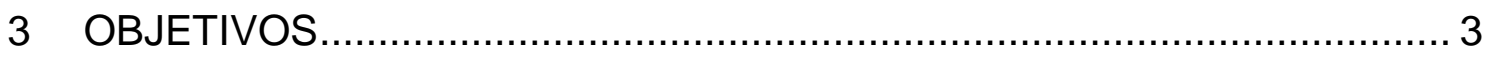

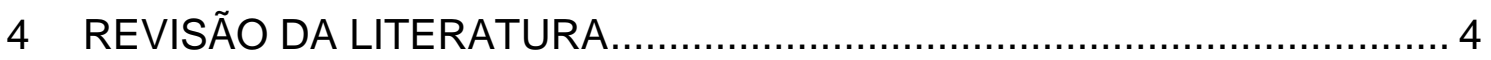

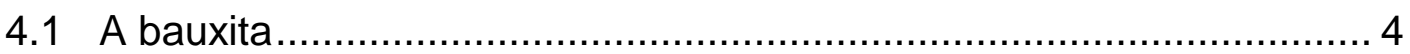

4.2 Depósitos de bauxita no mundo ................................................... 5

4.2.1 Depósitos de bauxita laterítica ................................................ 6

4.2.2 Depósitos de bauxita Sedimentares........................................ 7

4.2.3 Depósitos de bauxita sobre as rochas carbonáticas ................. 7

4.3 Depósitos de bauxita no Brasil ........................................................... 11

4.4 Gênese da bauxita de Miraí ….................................................... 15

4.5 Produção de Alumina e Alumínio...................................................... 19

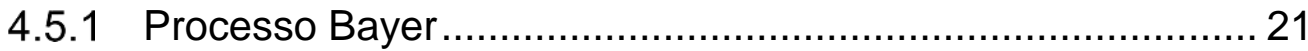

4.5.2 Processo Hall-Herault ......................................................... 24

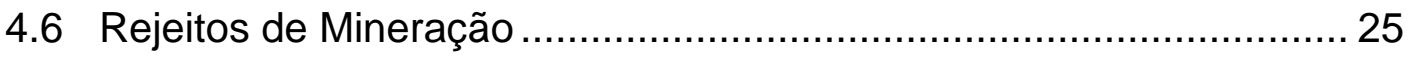

4.7 Rejeitos e resíduos de bauxita........................................................ 27

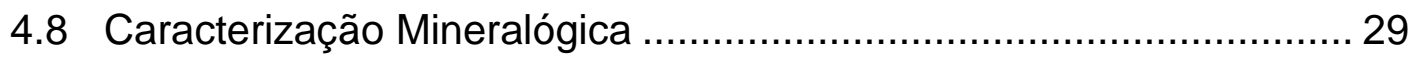

4.9 Propriedades geotécnicas dos rejeitos e resíduos da indústria mineral 30

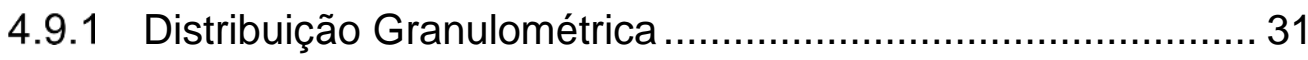

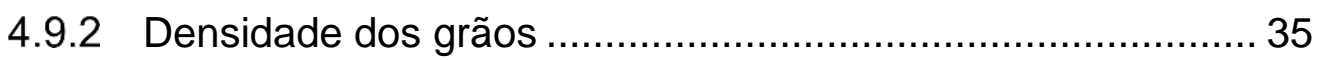


4.9.3 Limites de Atterberg …………......................................... 36

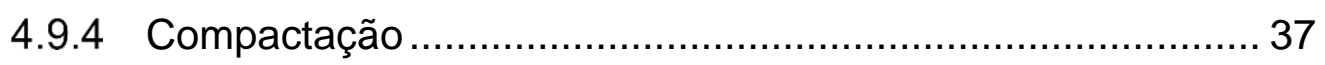

4.9.5 Condutividade Hidráulica .................................................... 39

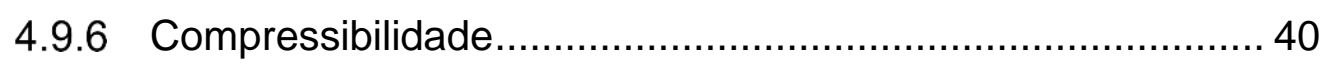

4.9.7 Resistencia ao cisalhamento............................................. 40

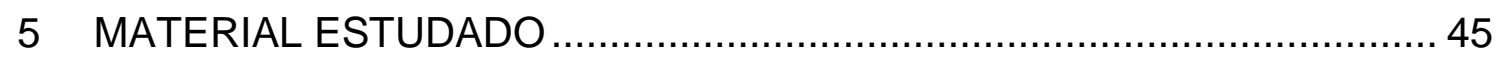

5.1 Rejeitos de bauxita lavada - Votorantim Metais - Unidade Miraí...... 45

5.2 Operações na planta de beneficiamento ......................................... 47

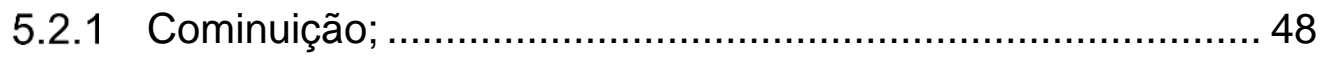

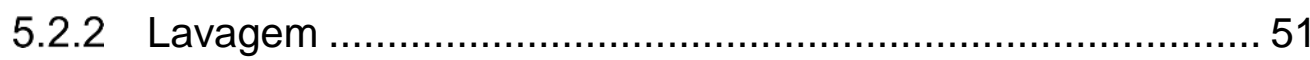

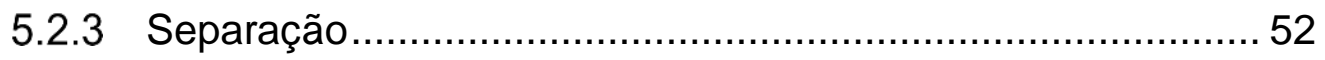

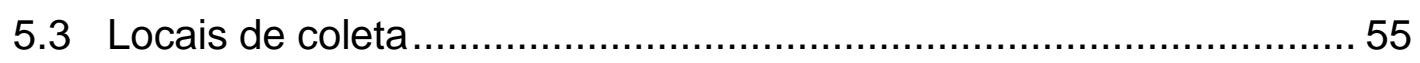

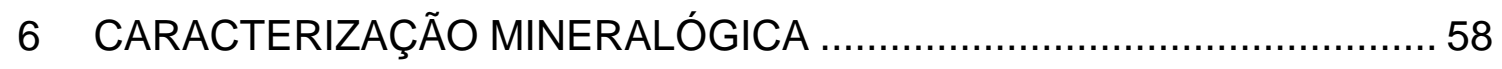

6.1 Análise de fluorescência de raios $x$............................................... 58

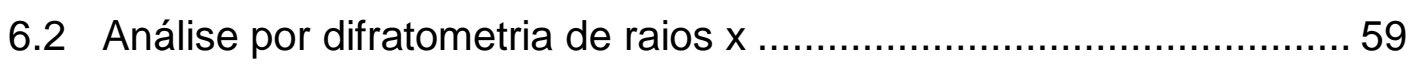

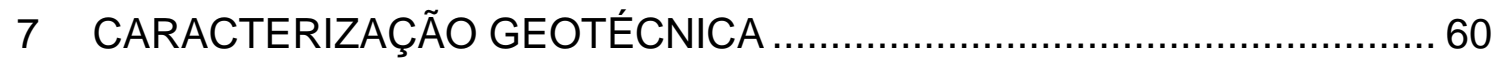

7.1 Ensaios de granulometria e limites de consistência ........................... 61

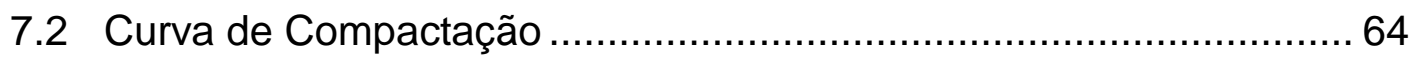

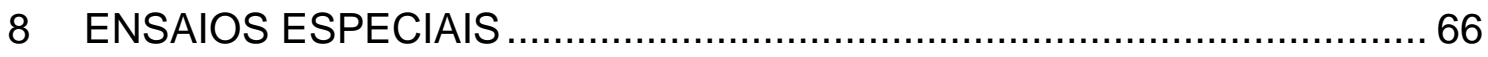

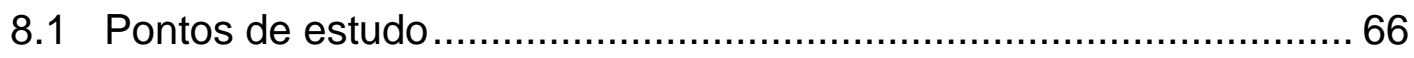

8.2 Ensaio oedômetrico e permeabilidade ............................................. 67

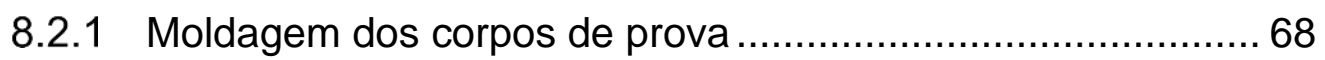

8.2.2 Resultados dos ensaios edométricos..................................... 68

8.3 Ensaio Triaxial Anisotrópico não Drenado (CAU) ............................. 71

8.3.1 O equipamento utilizado nos ensaios triaxiais ....................... 71

9 MÉTODO PARA EXECUÇÃO DO ENSAIO TRIAXIAL............................. 73

9.1 Moldagem dos corpos de prova..................................................... 73

9.2 Montagem na câmara triaxial........................................................... 74 


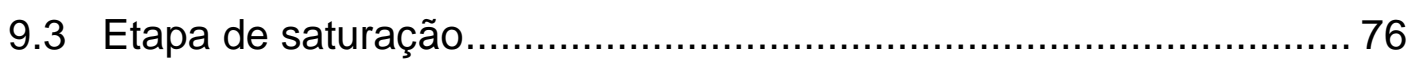

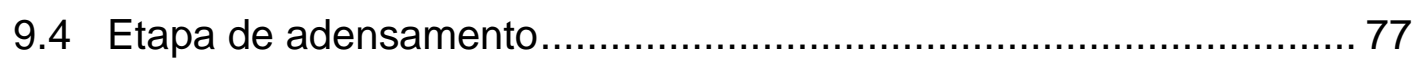

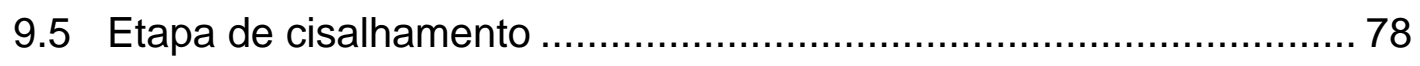

10 RESULTADOS E DISCUSSÕES DOS ENSAIOS TRIAXIAIS ................... 79

10.1 Características iniciais dos corpos de prova..................................... 79

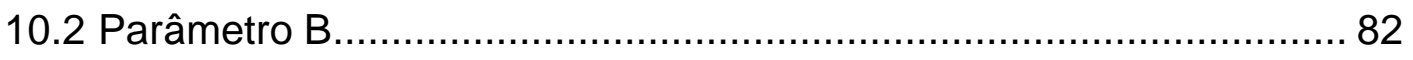

10.3 Curvas tensão desviadora-deformação axial.................................... 83

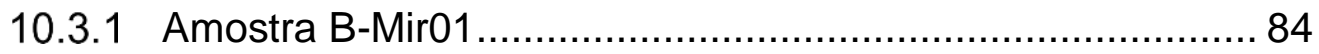

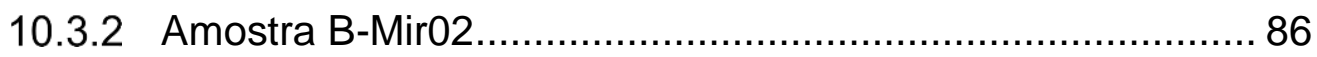

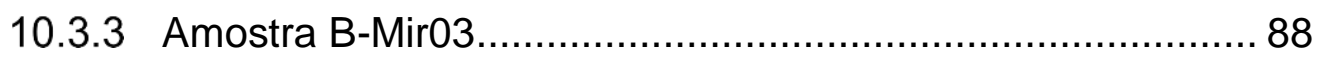

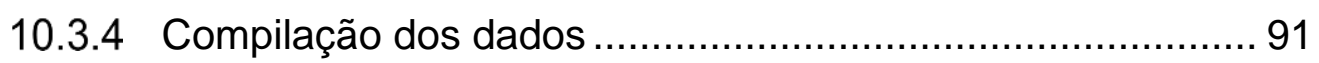

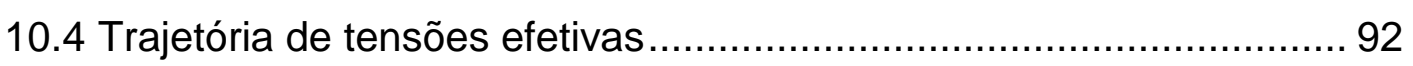

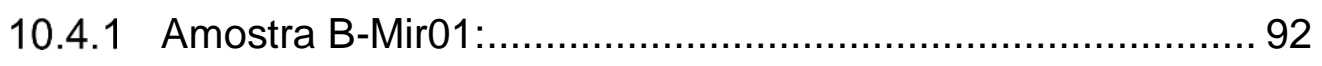

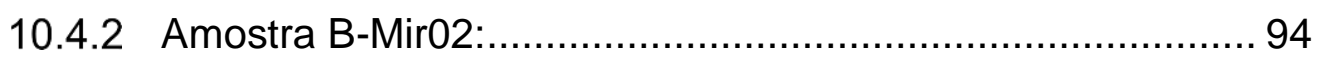

10.4.3 Amostra B-Mir03 - Ponto D3:............................................. 97

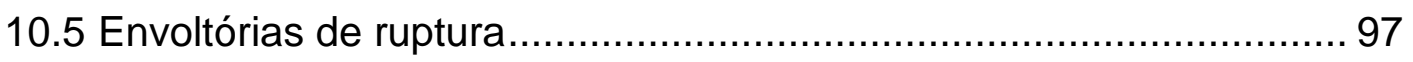

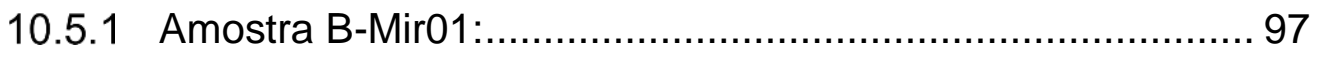

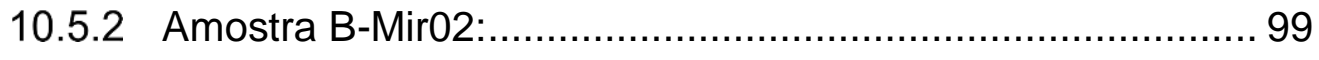

10.5.3 Amostra B-Mir03 - Ponto D3:.......................................... 100

10.6 Módulos de deformabilidade....................................................... 102

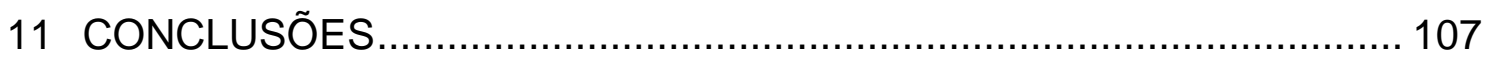

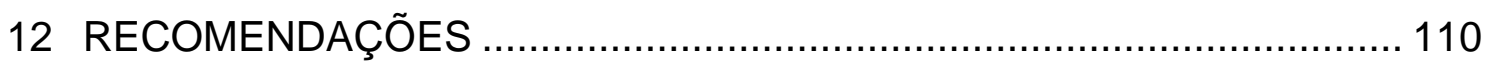

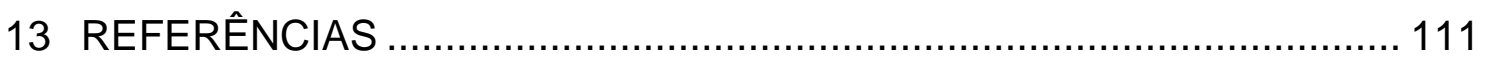

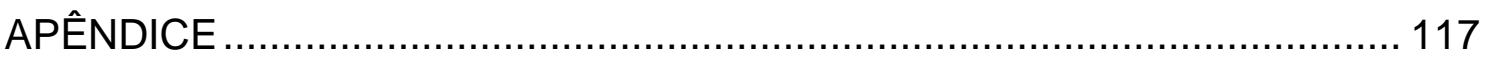

Apêndice 01 - Fotografias dos corpos de prova cisalhados na câmara triaxial em todos os pontos de estudo sob diferentes tensões confinantes.........117 Apêndice 02 - Texto em formato de artigo a ser submetido no Congresso Internacional Tailings \& Mine Waste...................................................... 120 


\section{LISTA DE FIGURAS}

Figura 4-1- Distribuição de depósitos de bauxita no mundo. (Fonte: Schult e Foley, 2014).

Figura 4-2- Reservas de bauxita no mundo em bilhões de toneladas para o ano base 2016. (Fonte: U.S. Geological Survey, 2017). 10

Figura 4-3- Maiores produtores de minério de bauxita no mundo em milhões de toneladas para o ano base 2016. (Fonte: U.S. Geological Survey, 2017)........ 11

Figura 4-4 - Localização das principais regiões bauxitíferas do Brasil (Modificado de: Kotschoubey, 1988).

Figura 4-5 - Produção de bauxita lavrada e bauxita beneficiada no Brasil - Ano base 2015 (Fonte: DNPM - Anuário mineral brasileiro, 2016). 14

Figura 4-6 - Localização das minas de bauxita e refinarias de alumina no Brasil (Fonte: Associação Brasileira de Alumínio - ABAL, 2017) 14

Figura 4-7 - Principais empresas produtoras de bauxita beneficiada no ano 2015 (Fonte: DNPM - Anuário mineral brasileiro, 2016) 15

Figura 4-8 - Localização do Município de Miraí no estado de Minas Gerais .... 16 Figura 4-9 - Mapa Geológico da área em estudo (Fonte: Modificado de Noce et al, 2002) 17

Figura 4-10 - Toposequências da área de Miraí (Fonte: Modificado de Lopes, 1987) 18

Figura 4-11 - Fáceis de alteração de um perfil da área de Miraí (Fonte: Lopes e Carvalho, 1990)

Figura 4-12 - Processo Bayer para obtenção da alumina. (Fonte: Modificado de Norsk Hydro, 2012) 23

Figura 4-13 - Esquema do processo Hall-Herault para obtenção do alumínio primário. (Fonte: Norsk Hydro, 2012).

Figura 4-14 - Resíduos de mineração gerados pelo processo de obtenção do alumínio (Bournay et al, 2006) 27

Figura 4-15 - Evolução histórica do processo de disposição da lama vermelha. (Fonte: Adaptado de Power et al 2009)... 28

Figura 4-16 - Distribuição granulométrica de rejeitos de lavagem provenientes da Australia. (a) Sem dispersante. (b) Com dispersante. (Fell et al 2015) ...... 32 Figura 4-17 - Curvas granulométricas de alguns rejeitos de mineração Fourie (1999). 
Figura 4-18 - Curvas granulométricas de bauxita e lama vermelha de Jamaica para diversas temperaturas de digestão e concentração de soda cáustica (Adaptado de Li, 1998).

Figura 4-19 - Curvas granulométricas de lama vermelha, cinzas e solo da cidade de Damanjodi, India (Rout et al., 2013).

Figura 4-20 - Classificação na carta de Casagrande de rejeito de bauxita lavada e rejeitos de bauxita após processo Bayer (red muds) 36

Figura 4-21 - Resultados de umidade ótima x peso seco máximo a partir dos ensaios Proctor normal e Proctor modificado realizados em amostras de lama vermelha da Índia (Reddy e Rao, 2016). 38

Figura 4-22 - Resultados de umidade ótima x peso seco máximo a partir dos ensaios Proctor normal e lama vermelha proveniente da Guinea (Gore et al, 2016). 39

Figura 4-23 - (a) Faixas granulométricas de solos suscetíveis a liquefação e não suscetíveis (b) Faixas granulométricas para rejeitos de mineração com baixa resistência a liquefação. (Fonte: Modificado de Terzaghi et al, 1996. 42

Figura 4-24 - Determinação do Índice de vazios critico (PINTO, 2006).

Figura 5-1 - Usina de beneficiamento de minério de bauxita - Unidade Miraí. (Autor,2016) 45

Figura 5-2- Fluxograma para obtenção do alumínio 48

Figura 5-3 - Alimentação da moega com pá carregadeira - Unidade Miraí (Acervo pessoal, fev./2016). 49

Figura 5-4 - Correia transportadora levando o minério bruto passando pelo extrator de sucatas - Unidade Miraí (Acervo pessoal, fev./2016). 50 Figura 5-5 - Britador do tipo sizer esmagando o minério bruto de bauxita Unidade Miraí (Acervo pessoal, fev./2016). 50

Figura 5-6 - Lavagem no tambor desagregador denominado Scrubber - Unidade Miraí (Acervo pessoal, fev./2016). 51

Figura 5-7 - Sistema de peneiramento - Unidade Miraí (Acervo pessoal, fev./2016) 53

Figura 5-8 - Pilha da bauxita beneficiada e barragem de contenção do rejeito da bauxita lavada - Unidade Miraí (Fonte: Autor, fev./2016). 53

Figura 5-9 - Tubulações e caixa de passagem para conduzir os rejeitos de bauxita lavada para seu lançamento na barragem - Unidade Miraí (Acervo pessoal, fev./2016). 54 
Figura 5-10 - Planta de beneficiamento, localização dos equipamentos de lavagem e classificação - Unidade Miraí (Acervo pessoal, fev./2016).............. 54 Figura 5-11 - Localização dos pontos de coleta das amostras na Mineração Miraí (Fonte: 2015 Digital Globe) 56

Figura 5-12- Pontos de coleta na praia de rejeitos (Acervo pessoal, fev. /2016). 56

Figura 6-1 - Difratogramas de raios x. (a) B-Mir-Ore. (b) B-Mir01. (c) B-Mir02. (d) B-Mir03. 59

Figura 7-1 - Preparação do rejeito-Mir03 para iniciar os ensaios de caracterização. . 60

Figura 7-2 - Curva granulométrica do rejeito de mineração de bauxita, com defloculante. 62

Figura 7-3 - Curva granulométrica do rejeito de mineração de mauxita com e sem defloculante. 62

Figura 7-4 - Carta de Plasticidade de Casagrande 63 Figura 7-5 - Curva de Compactação obtida para três amostras de rejeito de bauxita. 65

Figura 8-1 - Pontos de estudo na curva de compactação do rejeito de bauxita em estudo. 66

Figura 8-2 - Resultados ensaio oedométrico para o rejeito B-Mir01. 68

Figura 8-3 - Resultados ensaio oedométrico para o rejeito B-Mir02 ................ 69

Figura 8-4 - Resultados ensaio oedométrico para o rejeito B-Mir03................ 70 Figura 8-5 - Esquema da prensa Bishop \& Wesley (1975) utilizada na execução dos ensaios não drenados. 72

Figura 8-6 - Esquema de funcionamento do equipamento triaxial utilizado para realização dos ensaios. 72 Figura 9-1 - Ferramentas para a moldagem do corpo de prova. (a) Molde cilíndrico tripartido. (b) Prensa, molde e gabarito para moldagem estática do

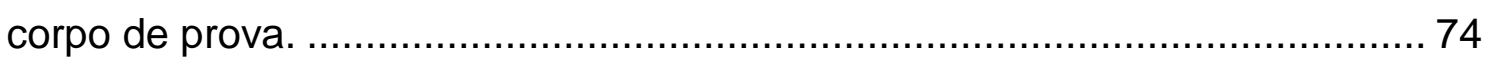

Figura 9-2 -Corpo de prova montado na base da câmara triaxial.................... 75 Figura 9-3 - Sequência de montagem do corpo de prova (C.P.). (a) C.P após moldagem. (b) C.P. com membrana. c) C.P. no interior da câmera triaxial d) C.P. após ruptura por deformação constante. 76

Figura 10-1 -Condição inicial dos corpos de prova moldados antes de iniciar o ensaio triaxial das amostras B-MIR01, e B-MIR02 e B-MIR03. 82 
Figura 10-2 -Resultados do parâmetro B para as amostras B-Mir01, B-Mir02 e B-Mir03 83

Figura 10-3 Resultados dos ensaios triaxiais para a amostra B-Mir01. Curvas tensão -deformação axial: (a) Ponto D1; (b) Ponto O1; (c) Ponto W1. Excesso de poropressão -deformação axial: (d) Ponto D1; (e) Ponto O1; (f) Ponto W1. Curva tensão normalizada - deformação axial: (g) Ponto D1; (h) Ponto O1; (i) Ponto W1 86

Figura 10-4 Resultados dos ensaios triaxiais para a amostra B-Mir02. Curvas tensão -deformação axial: (a) Ponto D2; (b) Ponto O2; (c) Ponto W2. Excesso de poropressão -deformação axial: (d) Ponto D2; (e) Ponto O2; (f) Ponto W2. Curva tensão normalizada - deformação axial: (g) Ponto D2; (h) Ponto O2; (i) Ponto W2. 88

Figura 10-5 Resultados dos ensaios triaxiais para a amostra B-Mir03 no ponto D3. (a) Curva tensão-deformação axial. (b) Excesso de poropressão-deformação axial. (c) Curva tensão normalizada-deformação axial.................................... 90

Figura 10-6 Trajetória de tensões efetivas para o ponto D1. ........................... 93

Figura 10-7 Trajetória de tensões efetivas para o ponto 01............................ 93

Figura 10-8 Trajetória de tensões efetivas para o ponto W1 ............................. 94

Figura 10-9 Trajetória de tensões efetivas para o ponto D2. ………............... 95

Figura 10-10 Trajetória de tensões efetivas para o ponto O2 .......................... 96

Figura 10-11 Trajetória de tensões efetivas para o ponto W2 ………............... 96

Figura 10-12 Trajetória de tensões efetivas para o ponto D3........................... 97

Figura 10-13 Círculos de Mohr obtidos para o ponto D1 e parâmetros de resistência efetiva a partir de ensaio triaxial CAU. .......................................... 98

Figura 10-14 Círculos de Mohr obtidos para o ponto $\mathrm{O} 1$ e parâmetros de resistência efetiva a partir de ensaio triaxial CAU. ........................................... 98

Figura 10-15 Círculos de Mohr obtidos para o ponto W1 e parâmetros de resistência efetiva a partir de ensaio triaxial CAU. ............................................ 99

Figura 10-16 Círculos de Mohr obtidos para o ponto D2 e parâmetros de resistência efetiva a partir de ensaio triaxial CAU. ......................................... 99

Figura 10-17 Círculos de Mohr obtidos para o ponto O2 e parâmetros de resistência efetiva a partir de ensaio triaxial CAU ....................................... 100 Figura 10-18 Círculos de Mohr obtidos para o ponto W2 e parâmetros de resistência efetiva a partir de ensaio triaxial CAU. ....................................... 100 
Figura 10-19 Círculos de Mohr obtidos para o ponto D3 e parâmetros de resistência efetiva a partir de ensaio triaxial CAU. 101

Figura 10-20 Resultados dos parâmetros de resistência. Coesão e ângulo de atrito 102

Figura 10-21 Módulos de deformabilidade secante (E) - B-Mir01. 104

Figura 10-22 Módulos de deformabilidade secante (E) - B-Mir02 104

Figura 10-23 Módulos de deformabilidade secante (E) - B-Mir03 ponto D3.. 105 Figura 10-24 Módulos de deformabilidade secante normalizados para todas as amostras ensaiadas. (a) B-Mir01, (b) B-Mir02 e (c) B-Mir03-Ponto D3 .......... 106 Figura 0-1- Corpos de prova ensaiados no ponto D1 .................................. 117 Figura 0-2 Corpos de prova ensaiados no ponto O1 .................................... 117

Figura 0-3 Corpos de prova ensaiados no ponto W1 .................................. 118

Figura 0-4 Corpos de prova ensaiados no ponto D2 .................................... 118

Figura 0-5 Corpos de prova ensaiados no ponto O2 ……............................. 118

Figura 0-6 Corpos de prova ensaiados no ponto W2 .................................. 119

Figura 0-7 Corpos de prova ensaiados no ponto D3 ................................... 119 


\section{LISTA DE TABELAS}

Tabela 4-1 Depósitos de bauxita nas principais províncias mineralizadas. (Adaptado de Schult e Foley, 2014) 9

Tabela 4-2 Distribuição dos depósitos de bauxita no Brasil. (Adaptado de Melfi, 1997; Kotschoubey et al, 2006; Santos, 2011) .......................................... 13

Tabela 4-3 Principais minerais, processamento e características dos seus rejeitos. (Fonte: Adaptado de Vick, 1983) ................................................. 26

Tabela 4-4 Quantidade de rejeitos gerados a partir da produção de bauxita lavada - Exemplos de mineradoras no Brasil. (Fonte: van Deursen, 2016)..... 29 Tabela 4-5 Análise mineralógica por fluorescência de raio $X$ de reservas de bauxita de Miraí. (Carvalho, 1989)........................................................... 30

Tabela 4-6 Valores de densidade dos grãos para lama vermelha. .................. 35

Tabela 4-7 Resultados de Limites de Atterberg para lama vermelha............... 36

Tabela 4-8 Valores de condutividade hidráulica para rejeitos de bauxita........ 39

Tabela 4-9 Resultados de parâmetros de compressibilidade de lama vermelha. 40

Tabela 4-10 Resultados de parâmetros de resistência de lama vermelha....... 40 Tabela 5-1 - Locais de coleta e denominação das três amostras estudadas. . 55 Tabela 6-1 - Resultados de fluorescência de raios x para as amostras em estudo.

Tabela 7-1 - Normas brasileiras para realização de ensaios de caracterização 61

Tabela 7-2 - Características do rejeito obtidas no laboratório 64

Tabela 7-3 - Características de compactação das três amostras de rejeito. ... 65

Tabela 8-1 - Características iniciais dos pontos de estudo. 67

Tabela 8-2 - Índice de recompressão (Cr), compressão (Cc) e de expansão (Ce) das amostras B-Mir01, B-Mir02 e B-Mir03.

Tabela 10-1-Características iniciais dos corpos de prova para ensaio triaxial tipo CAU 81

Tabela 10-2 - Resultados dos parâmetros de resistência. Coesão e ângulo de atrito 101

Tabela 10-3 - Resultados dos módulos de deformabilidade secante (Es) para as amostras B-Mir01, B-Mir02 e B-Mir03. 103 


\section{LISTA DE ABREVIATURAS E SIGLAS}

ABNT Associação Brasileira de Normas Técnicas

ASTM American Society for Testing Materials

DNPM Departamento Nacional de Produção Mineral

FEAM Fundação Estadual de Meio Ambiente 


\section{INTRODUÇÃO}

No processo de beneficiamento dos minérios são geradas quantidades consideráveis de resíduos sem aparente valor econômico e que exigem o seu adequado armazenamento. Estes resíduos devem ser dispostos em ambientes projetados para recebê-los, de forma segura e de modo a minimizar os impactos sobre o meio ambiente. Uma prática comum na mineração é a construção de barragens e diques para o armazenamento destes resíduos, sendo a barragem de rejeito o elemento mais usado para a disposição destes resíduos (quando dispostos por via úmida). As diversas técnicas de construção de barragens de rejeito (e.g. método de linha de montante, método de linha de centro, método de linha de jusante) devem se adequar as condições topográficas, hidrológicas, e geológico-geotécnicas do local da sua implantação (e.g. Vick, 1993). Além disto as características do rejeito e os aspectos relacionados com sua produção (contaminantes, velocidade de deposição, dentre outros) também devem ser levadas em conta.

No processo construtivo destas metodologias muitas vezes é necessário o uso de material compactado para a criação da barragem ou do dique de partida. $O$ comportamento mecânico e hidráulico dos materiais utilizados no aterro é fundamental para a segurança da construção. Em geral os materiais a serem utilizados nas barragens são aqueles disponíveis durante o processo de mineração (e.g. Bates, 2003) ou que estejam a uma distância economicamente viável. Quando se utiliza como material de construção da barragem o próprio resíduo ou parte dele é fundamental se conhecer as suas características mecânicas e hidráulicas.

Cada minério e cada processo de beneficiamento gera rejeitos com características mecânicas diferentes. A utilização destes rejeitos como material de construção nos aterros da barragem ou qualquer outro tipo de aterro, possui alguns problemas associados a variabilidade do material ao longo da sua geração. O comportamento geotécnico dos rejeitos está relacionado ás características do material, a natureza do depósito, e a forma como foi depositado. 
Embora existam vários aspectos a serem considerados, em geral associados a impactos ambientais, o uso de rejeitos de mineração como material de aterro exige um cuidado maior devido a sua natureza artificial.

O presente estudo trata do comportamento geomecânico de um resíduo de mineração de bauxita obtido na planta de beneficiamento em Miraí, Minas Gerais. Os materiais obtidos são provenientes do beneficiamento do minério bauxita. Salienta-se que os rejeitos estudados foram obtidos antes do processo Bayer, e, portanto, sem o componente químico associados a eles. Ao todo foram obtidas três amostras em diferentes locais na usina.

Este trabalho está dividido em onze capítulos. Nos capítulos, 2 e 3 as justificativas e objetivos, seguidos da revisão de literatura no capítulo 4. No quinto capitulo descreve-se em detalhes o material utilizado. No capítulo 6 apresentam-se as características mineralógicas do material estudado. Os resultados e discussões das características geotécnicas do material, que incluem os ensaios de caracterização, compactação e oedométrico estão apresentados no capítulo 7. O capítulo 8 apresenta o método para a execução dos ensaios triaxiais realizados. Os resultados e discussões desses ensaios encontram-se no capítulo 9. No capítulo 10 apresentam-se as conclusões dos estudos realizados e no capítulo 11 as sugestões de continuidade desta pesquisa.

Estão incluídos como apêndices ao trabalho: $O$ apêndice 1 que apresenta as fotografias dos corpos de prova rompidos no ensaio triaxial e no aapêndice 2 um artigo preliminar com parte das análises contidas nesta dissertação. 


\section{JUSTIFICATIVA}

Segundo levantamento realizado pela Fundação Estadual de Meio Ambiente (FEAM) de Minas Gerais para o ano base 2015, a quantidade de rejeitos de mineração em geral é da ordem de 242 milhões de toneladas (FEAM, 2016), dos quais aproximadamente $224.7 \mathrm{Mt}(\sim 95 \%)$ são dispostos por via úmida em barragens que exigem volumes de armazenamento cada vez maiores. Estes volumes criam situações de risco às populações localizadas a jusante e são um potencial problema ao meio ambiente. $\mathrm{O}$ uso de rejeitos como material de construção minimiza os volumes de rejeitos lançados nas barragens. Desta forma, o estudo aqui apresentado justifica-se por fornecer informações sobre o comportamento destes materiais, possibilitando o seu uso como material de construção, não somente nas áreas de mineração, mas também em obras rodoviárias e aterros em geral.

\section{OBJETIVOS}

O objetivo principal da dissertação é estudar o comportamento geomecânico do rejeito proveniente da lavra e beneficiamento do minério bauxita produzido na cidade de Miraí (MG). Para alcançar este objetivo as seguintes etapas foram cumpridas:

- Determinação da natureza do rejeito por meio da caracterização mineralógica.

- Caracterização e classificação do rejeito do ponto de vista geotécnico.

- Obtenção das características de compactação do material.

- Estudo das características de compressibilidade do material em ensaios edométricos, sob condições de compactação pré-estabelecidas.

- Avaliação do comportamento do material em termos de resistência ao cisalhamento, definindo envoltórias de ruptura, sob condições de compactação pré-estabelecidas.

- Avaliação do potencial gerador de poro-pressão durante o processo de cisalhamento.

- Determinação das características de deformabilidade do material nos ensaios triaxiais. 


\section{REVISÃo DA LITERATURA}

\subsection{A bauxita}

O alumínio é o terceiro elemento químico mais abundante, após o oxigênio e silício, constituindo cerca de $7 \%$ da massa da crosta terrestre e o elemento metálico mais abundante (e.g. Lumley, 2011). O alumínio não se encontra na natureza, o que é obtido são minerais de alumina trihidratada e monohidratada predominantes na composição química de rochas residuais, esta matéria prima denominada: Bauxita. Hoje em dia a bauxita continua sendo considerada a principal matéria prima para a produção do alumínio primário.

O óxido de alumínio, denominado alumina $\left(\mathrm{Al}_{2} \mathrm{O}_{3}\right)$, é extraído da bauxita por meio do processo hidrometalúrgico Bayer. A alumina por sua vez passa por um processo de redução eletrolítica "Hall-Hérault" de onde se obtém o alumínio primário. Hoje em dia, os processos Bayer e Hall-Héroult continuam sendo os métodos mais econômicos para a produção de quantidades comerciais de alumínio e são o principal suporte da indústria primária de alumínio.

Atribui-se o descobrimento da bauxita ao mineralogista e geólogo Pierre Berthier que em 1821 encontrou sedimentos ricos em alumínio nas proximidades de "Les Beaux de Provence" (Bouches du Rhône) na França, denominando-os "alumina hidratada de Beaux". Em 1847, Armand Dufrénoy denomina o minério como "Beauxite". O minério foi renomeado por Henri Sainte-Claire Deville em 1861, que o designou como "Bauxite", e, assim surgia a denominação: "bauxita". De acordo com Valeton (1972), o termo bauxita é usado para produtos do intemperismo ricos em alumina, porém pobres em álcalis, alcalinos terrosos e sílica.

De acordo com Klein e Hurlbut Jr. (2003), a bauxita é uma rocha de cor avermelhada, apresentado uma mistura de óxidos de alumínio hidratados de composição não definida. Para Bardossy e Aleva (1990) e Parekh e Goldberger (1976), a bauxita é um tipo de rocha que consiste na combinação de um ou mais minerais de hidróxido de alumínio, sendo estes, principalmente:

- A gibbsita $\left(\mathrm{Al}(\mathrm{OH})_{3}\right)$, também chamada de hidrargilita, que é uma forma tri-hidratada de alumina $\left(\mathrm{Al}_{2} \mathrm{O}_{3} .3 \mathrm{H}_{2} \mathrm{O}\right)$; 
- A boemita ( $(\mathrm{y}-\mathrm{AlO}(\mathrm{OH}))$ e diásporo ( $(\mathrm{\alpha}-\mathrm{AlO}(\mathrm{OH}))$; que são duas formas de alumina mono-hidratada $\left(\mathrm{Al}_{2} \mathrm{O}_{3} \cdot \mathrm{H}_{2} \mathrm{O}\right)$. Como observado a composição química geral do diásporo é a mesma que a da boemita, porém o diásporo é mais duro e denso.

A bauxita geralmente também possui na sua composição:

- Minerais de ferro como: Goethita $(\mathrm{FeO}(\mathrm{OH}))$ e hematita $\left(\mathrm{Fe}_{2} \mathrm{O}_{3}\right)$;

- Minerais de sílicato de alumínio hidratado como os argilominerais: Caulinita $\left(\mathrm{Al}_{2} \mathrm{Si}_{2} \mathrm{O}_{5}(\mathrm{OH})_{4}\right)$ e a haloisita;

- O titânio também está presente com pequenas quantidades de anatásio ( $\mathrm{TiO}_{2}$ ) ou rutilo;

- A sílica presente também, na forma de quartzo;

\subsection{Depósitos de bauxita no mundo}

De acordo com Carvalho (1989), os primeiros depósitos conhecidos de bauxita foram localizados no sul da França e na Europa Central associados às rochas carbonáticas, as quais foram consideradas como rochas mães das bauxitas. Outros depósitos foram descobertos nas regiões tropicais, materiais ricos em alumínio sobre as rochas ígneas e metamórficas e também na forma depósitos sedimentares.

Existem diversas propostas para tipos de classificação da bauxita na literatura. Diversos autores apresentam históricos sobre a classificação da Bauxita a partir dos anos 20 (e.g. Bardossy, 1982; Kotschoubey, 1988; Carvalho, 1989).

Harrossowitz (1926), apud Kotschoubey (1988), observou a existência de dois grupos: As bauxitas sobre rochas carbonáticas e as bauxitas sobre as rochas silicáticas. Os termos "bauxita laterítica" e "bauxita de carst" foram introduzidos por Vadasz (1951). Investigadores como: Hose (1960), Valeton (1972), Patterson (1967) e Grubb (1973) abordaram outros critérios de classificação, tais como: Geomorfologia; natureza do substrato; a forma dos corpos mineralizadores e suas relações com as rochas associadas/encaixantes; altitude na qual se realizou a bauxitização.

Lelong et al (1976), apud Carvalho (1989), levaram em conta para a classificação critérios ligados às características morfológicas dos depósitos e aspecto 
puramente genéticos (e.g. dividindo os depósitos de bauxita em três grupos: Bauxitas lateríticas de cobertura; Bauxitas sedimentares e; Bauxita de Carst. Segundo publicação de Paz (2016), a bauxita pode ser classificada também quanto à sua composição química e mineralógica e quanto à finalidade tecnológica a qual pode ser metalúrgica e não metalúrgica.

A seguir, será utilizada a classificação de Bardossy (1982) para apresentar os depósitos existentes. Bardossy (1982) deu ênfase à litologia do substrato, apresentando dois grupos fundamentais: os depósitos sobre rochas aluminosílicaticas e as rochas carbonáticas. O primeiro grupo (alumino-sílicaticas) foi subdividido em: Depósitos lateríticos e depósitos sedimentares, tipicamente alóctones (tipo Tikhvin). Esta classificação é mais global e mais clara apesar de não considerar o ambiente tectônico de formação (e.g Kotschoubey, 1988).

\subsubsection{Depósitos de bauxita laterítica}

Estes depósitos representam aproximadamente $85 \%$ das reservas mundiais.

a) Origem: Depósitos autóctones, cuja formação depende de um intemperismo intenso em condições de clima tropical e subtropical úmido (Bardossy, 1994) de rochas alumino-silicáticas variadas e mantidos no local da intemperização.

b) Ocorrência: Sob a forma de blankets ou corpos lenticulares capeando zonas aplainadas, relevos tabulares e platôs, restos de antigas superfícies, dissecadas por processos erosivos mais recentes. Sua espessura média não maior é de $10 \mathrm{~m}$ de minério aproveitável, e apresenta variações laterais nos teores de alumínio (Al), ferro $(\mathrm{Fe})$ e silício (Si). As bauxitas são mais comuns de ocorrerem dentro de perfis lateríticos de grande espessura, formados por meteorização subaérea, intemperismo químico prolongado e lixiviação de rochas de aluminossílicatos (Bardossy e Aleva, 1990; Ferenczi, 2001; Retallack, 2010). Estas rochas podem ser granito, gnaisse, basalto, sienito e xisto.

c) Litologia: Variada, havendo tipos friáveis e tipos altamente litificados. Suas texturas são: oolita, pisoliticas, adanitica, esponjosa, concrecionada, celular, etc.

d) Composição química: Varia segundo a sua idade, depósitos mais novos são gibbsiticos; nos depósitos lateríticos mais antigos, a boemita 
é mais abundante. Toda a extensa faixa continental quente e úmida, delimitada pela linha do Equador, é objeto do intemperismo químico (e.g. Sgarbi, 2012). Assim, se justifica que a maior parte do território brasileiro esteja coberto por formações lateríticas. Desta forma, os depósitos de bauxita laterítica originam-se em função de transformações químicas supergênicas (processos que ocorrem próximos da superfície da terra, originárias por soluções descendentes) havendo uma concentração de compostos insolúveis de alumínio, muitos deles com valor econômico.

e) Cor: Segundo Bardossy e Aleva (1994) a cor da bauxita lateritica pode variar de quase branco a rosa, amarelo, laranja, avermelhado e marrom.

\subsubsection{Depósitos de bauxita Sedimentares}

a) Origem: São depósitos de natureza alóctone, sedimentares, sem associação aos estratos carbonáticos. O substrato das formações pode ser de natureza ígnea, metamórfica ou sedimentar.

b) Ocorrência: Segundo Bardossy (1982) este grupo é de menor importância econômica e representa entre 1 a $2 \%$ das bauxitas. Ocorrem em regiões tectonicamente estáveis, plataformais ou paraplataformais. Maiormente encontradas, na parte basal de coberturas sedimentares.

c) Litologia: A composição mineralógica destes depósitos aparenta ser independente da sua idade. Seus principais minerais constituintes são: Gibbsita, boemita e caulinita em proporções variáveis.

\subsubsection{Depósitos de bauxita sobre as rochas carbonáticas}

a) Origem: Rochas carbonáticas que apesar de terem pouco alumínio, terminam gerando depósitos de bauxita devido à facilidade com que os carbonatos são dissolvidos e lixiviados deixando o alumínio concentrado (Santos, 2011).

b) Ocorrência: Bauxitas cársticas ocorrem em depressões paleocársticas em forma de acumulações de material argiloso dentro de sequencias de carbonato, por exemplo calcário e dolomita (Bárdossy, 1982; 
Pajović, 2009). Depósitos de bauxitas cársticas comercialmente significativos ocorrem na Europa, Oriente Médio, China e Jamaica.

c) Litologia: A composição mineralógica deste tipo de bauxita varia em função da idade do minério. O mineral mais presente e abundante é a boemita, porém depósitos mais antigos são diaspóricos e bohemiticosdiaspóricos.

d) Cor: A cor destas bauxitas tende a ser pretas de cor cinza misturadas com matéria orgânica, podendo apresentar minerais como a pirita. (Retallack, 2010).

A Figura 4-1 ilustra a distribuição dos depósitos de bauxita no mundo agrupadas nas principais províncias mineralizadas. Bogatyrev e Zhukov (2009) definiram as 19 províncias indicadas na figura. Sendo estas: Pacífico oriental, América do norte, Caribe, sul-americana, africana, mediterrânea, leste europeu, Urais, cazaque, Ásia central, salair, siberiana do leste, hindustão, chinesa, indochina, indonésia-filipina, Austrália ocidental, leste da Austrália e havaiana.

Exemplos de bauxita laterítica podem ser encontrados em Weipa, Queensland, na Austrália (ponto 1 na figura); Pitinga, Paragominas, Porto Trombetas; Cataguases, Miraí, Poços de Caldas localizados no Brasil (pontos 4-9). Depósitos de bauxitas cársticas podem ser encontrados na Turquia no depósito Doğankuzu localizado Seydisehir (ponto 2), na China em Nanting, Kunmin e Queyang (pontos 16-18).

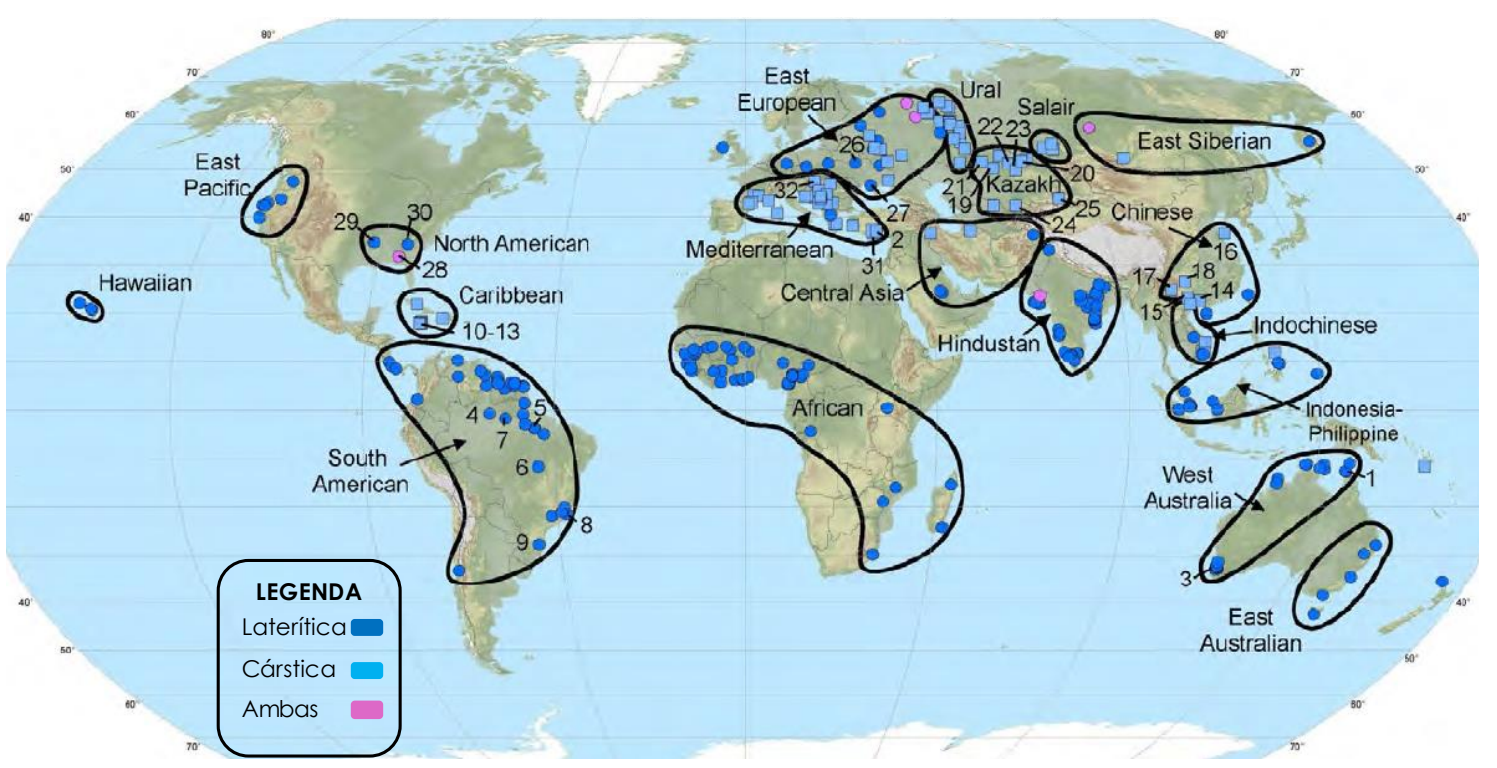

Figura 4-1- Distribuição de depósitos de bauxita no mundo. (Fonte: Schult e Foley, 2014). 
Os depósitos de bauxitas sedimentares podem ser encontrados na região de Tikvvin na Rússia (Kirpal, 1973), Arkansas, regiões dos Urais e Sibéria.

A Tabela 4-1 apresenta os depósitos selecionados de cada região mineralizada da Figura 4-1 indicados com seus respectivos números.

Tabela 4-1 Depósitos de bauxita nas principais províncias mineralizadas. (Adaptado de Schult e Foley, 2014)

\begin{tabular}{|c|c|c|c|}
\hline $\begin{array}{l}\text { Província } \\
\text { mineralizada }\end{array}$ & Pais & $\begin{array}{c}\text { Número e nome do } \\
\text { depósito }\end{array}$ & Tipo de depósito \\
\hline Austrália ocidental & Autrália & $\begin{array}{c}\text { 1-Weipa, } \\
\text { 3-Darling Range }\end{array}$ & Laterítico \\
\hline Sulamericana & Brasil & $\begin{array}{l}\text { 4-Pitinga, } \\
\text { 5-Tucuruí, } \\
\text { 6-Paragominas, } \\
\text { 7-Porto Trombetas, } \\
\text { 8-Cataguases, } \\
\text { 9-Poço de Caldas }\end{array}$ & Laterítico \\
\hline Caribe & Jamaica & $\begin{array}{l}\text { 10-Saint Ann, } \\
\text { 11-Saint Catherine, } \\
\text { 12-Saint Elizabeth, } \\
\text { 13-Manchester }\end{array}$ & Cárstico \\
\hline China/Indochina & China & $\begin{array}{c}\text { 14-Dajia, } \\
\text { 15-Xinxu, } \\
\text { 16-Nanting, } \\
\text { 17-Kunmin, } \\
\text { 18-Queyang) }\end{array}$ & Cárstico/Laterico \\
\hline Cazaque & Casaquistão & $\begin{array}{c}\text { 19-Arqalyk, } \\
\text { 20-Ekisbatoz-Pavlodar, } \\
\text { 21-Naurzum, } \\
\text { 22-Astana, } \\
\text { 23-Aqtas, } \\
\text { 24-Shimkent, } \\
\text { 25-lli }\end{array}$ & Cárstico \\
\hline Mediterrâneo & Turquia & $\begin{array}{l}\text { 2-Doğankuzu, } \\
\text { 31-Maşatdaği }\end{array}$ & Cárstico \\
\hline Mediterrâneo & Hungría & 32-Iszkaszentgyörgy & Cárstico \\
\hline Leste Europeu & Ucrânia & $\begin{array}{c}\text { 26-Pripyat, } \\
\text { 27-Vysokopl'ye }\end{array}$ & Cárstico \\
\hline América do norte & $\begin{array}{l}\text { Estados } \\
\text { Unidos }\end{array}$ & $\begin{array}{l}\text { 28-Eufaula, } \\
\text { 29-Pulaski-Saline, } \\
\text { 30-Hall-Veneer }\end{array}$ & Cárstico/Laterítico \\
\hline
\end{tabular}


Segundo o Serviço Geológico dos Estados Unidos (USGS - United States Geological Survey) na publicação do sumário mineral para a Bauxita e Alumina de 2017, ano base 2016 (USGS, 2017) as reservas mundiais de bauxita somaram 28 bilhões de toneladas e se tem uma estimativa de que os recursos de bauxita totais no mundo estejam entre 55 e 75 bilhões de toneladas.

A publicação acima mencionada também apresenta a quantificação das reservas de bauxita em porcentagem, as quais se distribuem da seguinte forma: $32 \%$ na África (p.ex. Guine), 23\% Oceania (p.ex. Austrália) 21\% América do Sul e Caribe (p.ex.: Brasil e Jamaica), 18\% na Ásia (p.ex. Vietnam, Índia, China, etc.) e 6\% no restante do mundo. A Figura 4-2 apresenta um mapa mundial destacando os países que detém as maiores reservas de bauxita, estas quantidades foram levantadas pela USGS para o ano 2016, sendo que o Brasil ocupa a terceira posição com reservas equivalentes a 2.6 bilhões de toneladas de bauxita.

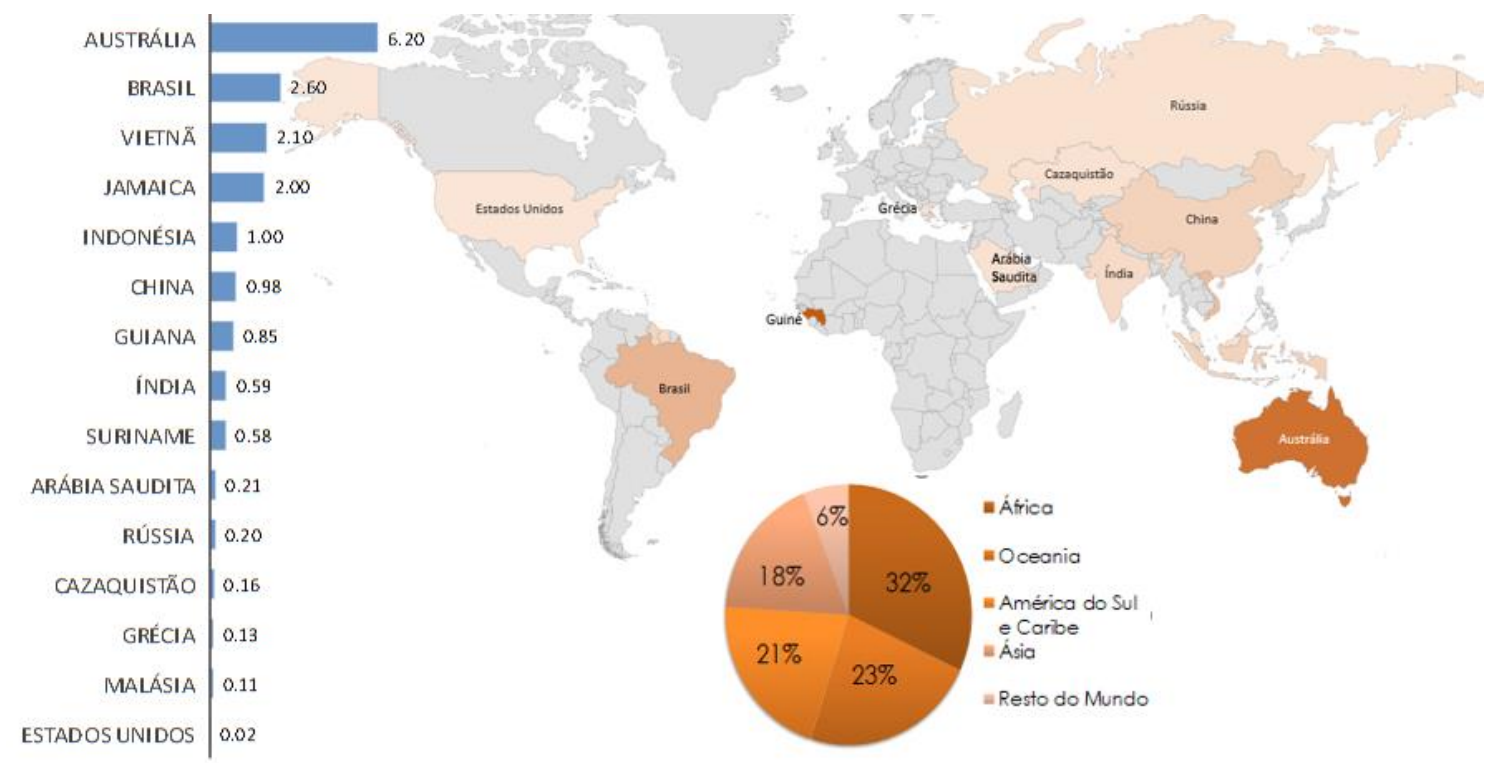

Figura 4-2- Reservas de bauxita no mundo em bilhões de toneladas para o ano base 2016. (Fonte: U.S. Geological Survey, 2017).

No sumário mineral 2011, do Departamento Nacional de Produção Mineral (DNPM) para o Alumínio (Martires,2011), levantou que, 96\% das reservas brasileiras são do tipo metalúrgico, utilizada na produção do alumínio primário, enquanto que os $4 \%$ restantes são de origem não metalúrgico ou refratário.

No sumário mineral da USGS (2017), pode ser encontrada também a quantidade de produção mundial de bauxita minerada, a qual atingiu os 262 milhões de toneladas. A Figura 4-3 mostra os maiores produtores de minério de bauxita no mundo: A Austrália é o maior produtor com 82 milhões de toneladas; o segundo 
lugar é ocupado pela China com 65 milhões de toneladas. Brasil fica em terceiro lugar com 34.5 milhões de toneladas.

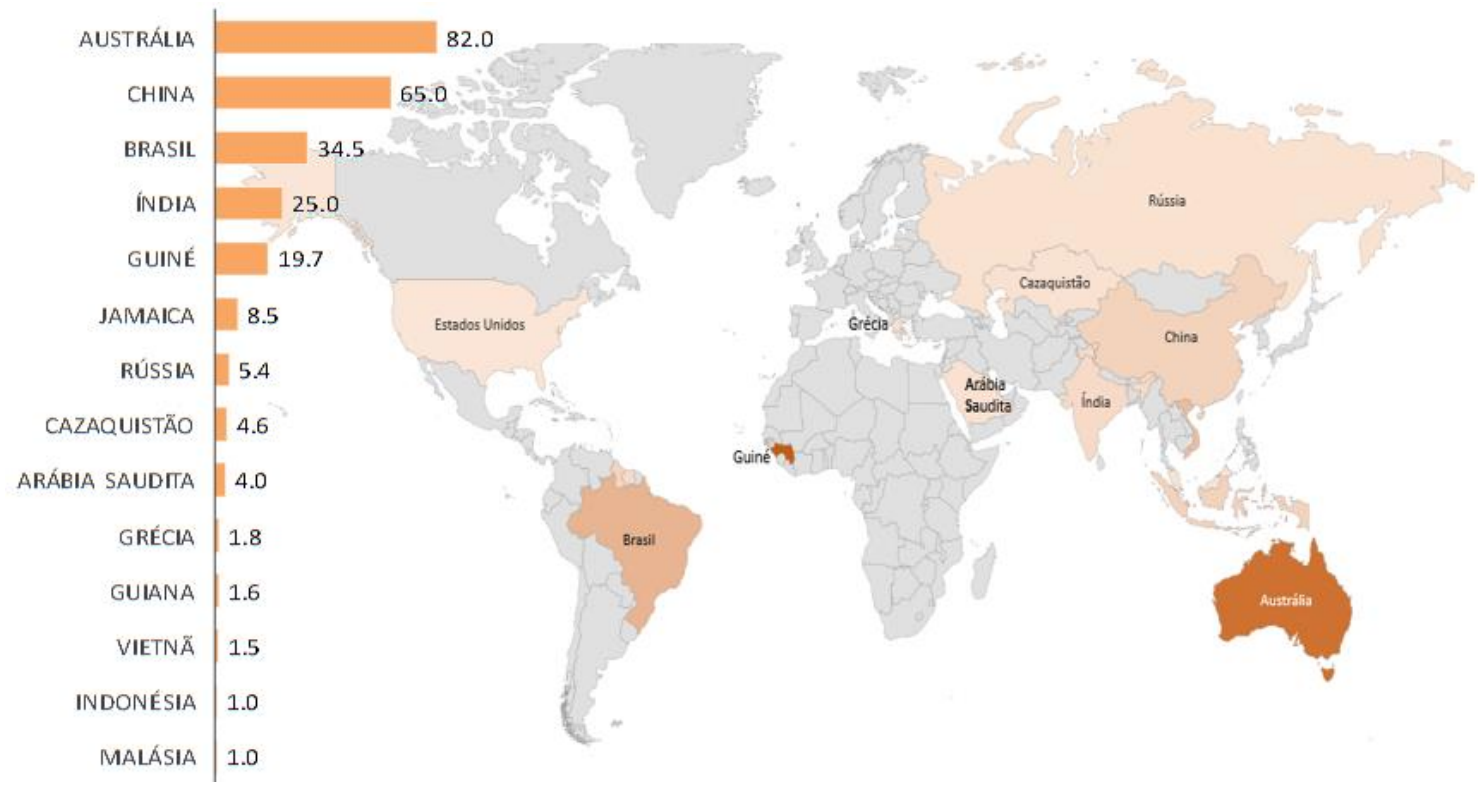

Figura 4-3- Maiores produtores de minério de bauxita no mundo em milhões de toneladas para o ano base 2016. (Fonte: U.S. Geological Survey, 2017)

\subsection{Depósitos de bauxita no Brasil}

Os depósitos de bauxita do Brasil são de origem laterítica e sua gênese foi determinada pelas condições climáticas e geomorfológicas. Os depósitos são constituídos basicamente por gibbsita e são formados a partir de intemperismo tropical intenso de diferentes tipos de rocha, que faz com que os aspectos litológicos sejam menos importantes. (e.g. Kotschoubey (1988); Melfi (1997)).

De acordo com Melfi (1997), a identificação dos diversos tipos de bauxita que levou a conhecer a distribuição dos depósitos de bauxita no Brasil, foi realizada através de estudos de pesquisadores, onde se destacam: Almeida, (1977); Dennen e Norton, (1977); Grubb, (1979); Sigolo, (1979); Aleva, (1981); Melfi e Carvalho, (1984); Varajão, (1988); e Valeton et al. (1991). Com estes estudos foi visto que segundo a rocha-mãe podem ocorrer três tipos principais de depósitos de bauxita no Brasil.

O depósito mais importante se refere às bauxitas formadas a partir de rochas sedimentares clásticas (com exceção de Carajás). Estes depósitos se concentram na região amazônica e correspondem a 97\% de total de depósitos no Brasil. O 3\% restante, ocorre em diferentes regiões do sul e sudeste brasileiro e foram formados a partir de outros tipos de rochas, como as rochas cristalinas 
pré-cambrianas como: Granitos, xistos, anfibolitos e gnaisses; rochas metassedimentares (filitos) e rochas alcalinas.

Levando em consideração as diversas litologias associadas aos depósitos de bauxita ou as regiões nas quais ocorrem, os depósitos podem ser agrupados em 03 tipos (e.g. Melfi, 2017) e estes são:

a) Bauxita da província da Amazônia Oriental - Formada principalmente sobre as rochas sedimentares clásticas. Também inclui a região de Carajás formada sobre rochas pré-cambrianas metavulcânicas básicas e itabiritos.

b) Bauxita da província Central da Mantiqueira - Formada sobre rochas précambrianas. Inclui a bauxita do Quadrilátero Ferrífero, formada sobre rochas sedimentares, metavulcânicas e sedimentares. Também estão inclusos o complexo Juiz de Fora e o complexo costeiro.

c) Bauxita da região sul e sudeste - Formada sobre depósitos de rochas alcalinas.

A Figura 4-4 mostra a localização das principais regiões bauxitiferas do Brasil.

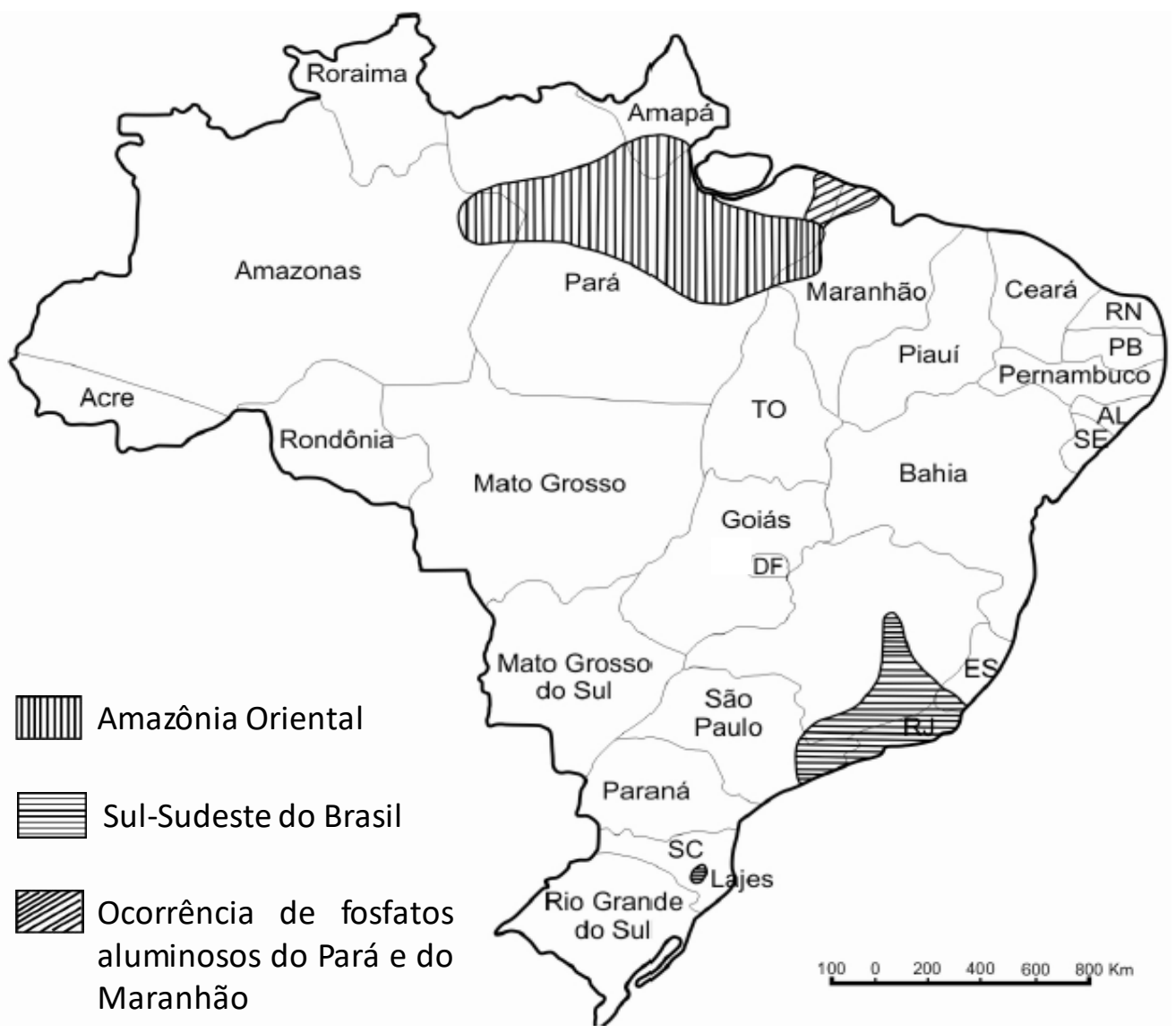

Figura 4-4 - Localização das principais regiões bauxitíferas do Brasil (Modificado de: Kotschoubey, 1988). 
A Tabela 4-2 apresenta um resumo com os principais depósitos de bauxita no Brasil.

Tabela 4-2 Distribuição dos depósitos de bauxita no Brasil. (Adaptado de Melfi, 1997; Kotschoubey et al, 2006; Santos, 2011)

\begin{tabular}{|c|c|c|c|}
\hline REGIÃO & ESTADO & DEPÓSITO & ROCHA-MÄE \\
\hline \multirow{5}{*}{$\begin{array}{c}\text { Norte } \\
\text { (Amazônica) }\end{array}$} & \multirow{3}{*}{ Pará } & $\begin{array}{c}\text { Almerin } \\
\text { Porto Trombetas } \\
\text { (Oriximiná, Faro, Juruti) }\end{array}$ & $\begin{array}{c}\text { Sedimentos } \\
\text { arcoseanos, arenoso- } \\
\text { argilosos (terciário) }\end{array}$ \\
\hline & & Carajás (Marabá) & Basalto \\
\hline & & Rondon de Pará & $\begin{array}{l}\text { Arenito arcoseano, } \\
\text { siltitos e argilitos }\end{array}$ \\
\hline & $\begin{array}{c}\text { Pará/ } \\
\text { Maranhão }\end{array}$ & $\begin{array}{c}\text { Paragominas (Ourem e } \\
\text { Irituia) }\end{array}$ & $\begin{array}{l}\text { Sedimentos areno- } \\
\text { argilosos (Terciário) }\end{array}$ \\
\hline & Amapá & Morro do Felipe & Sedimentos \\
\hline \multirow{11}{*}{$\begin{array}{c}\text { Quadrilátero } \\
\text { Ferrífero e } \\
\text { Província } \\
\text { Mantiqueira } \\
\text { Central }\end{array}$} & \multirow{7}{*}{ Minas Gerais } & Fraga & Filito \\
\hline & & Nova Lima & Riodacito \\
\hline & & Macaquinho & Sedimentos \\
\hline & & Cataguases & Gnaisse \\
\hline & & Itamarati de Minas & Gnaisse \\
\hline & & Descoberto & Anfibolito \\
\hline & & Miraí & $\begin{array}{c}\text { Gnaisse enderbítico e } \\
\text { charknokito }\end{array}$ \\
\hline & \multirow{3}{*}{ São Paulo } & Nazaré Paulista & Anfibolito \\
\hline & & Curucutu & Diabásio \\
\hline & & Mogi das Cruzes & Granito \\
\hline & $\begin{array}{l}\text { Rio de } \\
\text { Janeiro }\end{array}$ & $\begin{array}{l}\text { Resende, Rio Bonito, } \\
\text { Piraí, Itatiaia }\end{array}$ & Rochas Alcalinas \\
\hline \multirow{3}{*}{ Sul-Sudeste } & Minas Gerais & $\begin{array}{c}\text { Poços de caldas } \\
\text { (Andradas, Caldas) }\end{array}$ & \multirow{2}{*}{$\begin{array}{l}\text { Rochas Alcalinas (K- } \\
\text { Terciário) Sienitos }\end{array}$} \\
\hline & $\begin{array}{l}\text { Rio de } \\
\text { Janeiro }\end{array}$ & $\begin{array}{c}\text { Passa Quatro (Itamonte, } \\
\text { Lavrinha, Itanhandu) }\end{array}$ & \\
\hline & $\begin{array}{c}\text { Santa } \\
\text { Catarina }\end{array}$ & Lages & $\begin{array}{l}\text { Basalto, Diabásio, } \\
\text { Fonolito }\end{array}$ \\
\hline Centro-Oeste & Goiás & Barro Alto & Anortosito \\
\hline
\end{tabular}

O Departamento Nacional de produção Mineral (DNPM) publicou no seu anuário mineral Brasileiro 2016 (ano base 2015) as quantidades produzidas de bauxita lavrada e de bauxita beneficiada no país por estado. A Figura 4-5 mostra que mais de $90 \%$ da produção corresponde ao estado de Pará, nas localidades de: Oriximiná, Juruti, Rondon do Pará e Paragominas; seguido do estado de Minas Gerais (Poços de Caldas, Cataguases, Miraí, etc.). Nos estados de São Paulo e Santa Catarina a bauxita explorada é para uso não metalúrgico, a qual termina abastecendo o mercado de consumo do próprio estado, e o mercado de Minas Gerais. 


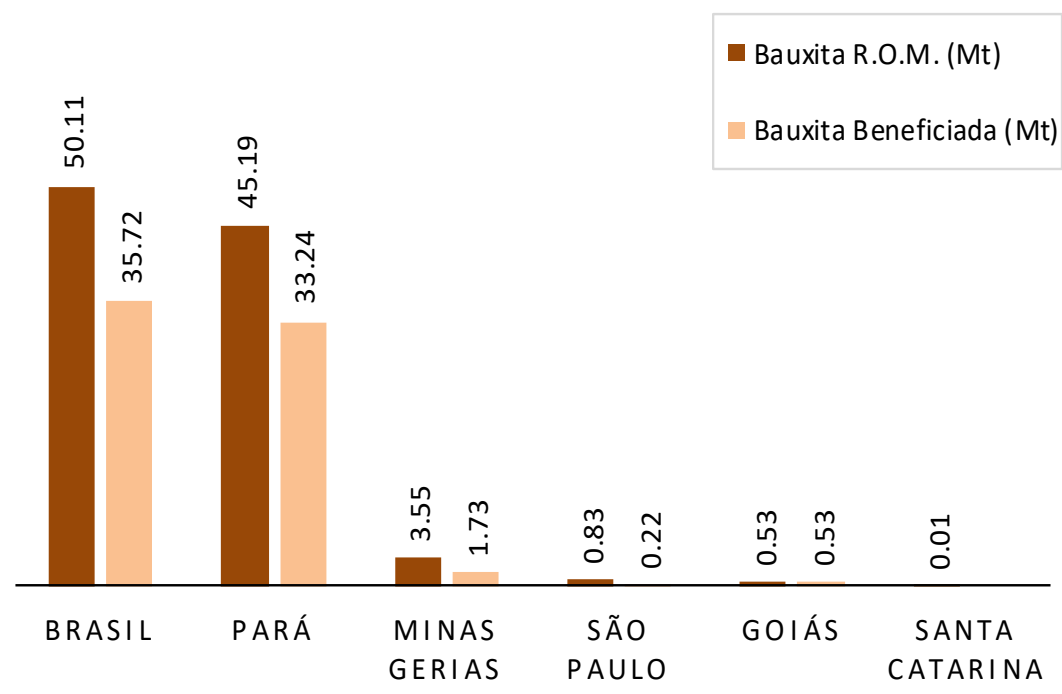

Figura 4-5 - Produção de bauxita lavrada e bauxita beneficiada no Brasil - Ano base 2015 (Fonte: DNPM - Anuário mineral brasileiro, 2016).

A Figura 4-6 apresenta a localização e identificação das minas em operação mencionadas anteriormente, assim como a localização das refinarias que operam atualmente no Brasil.

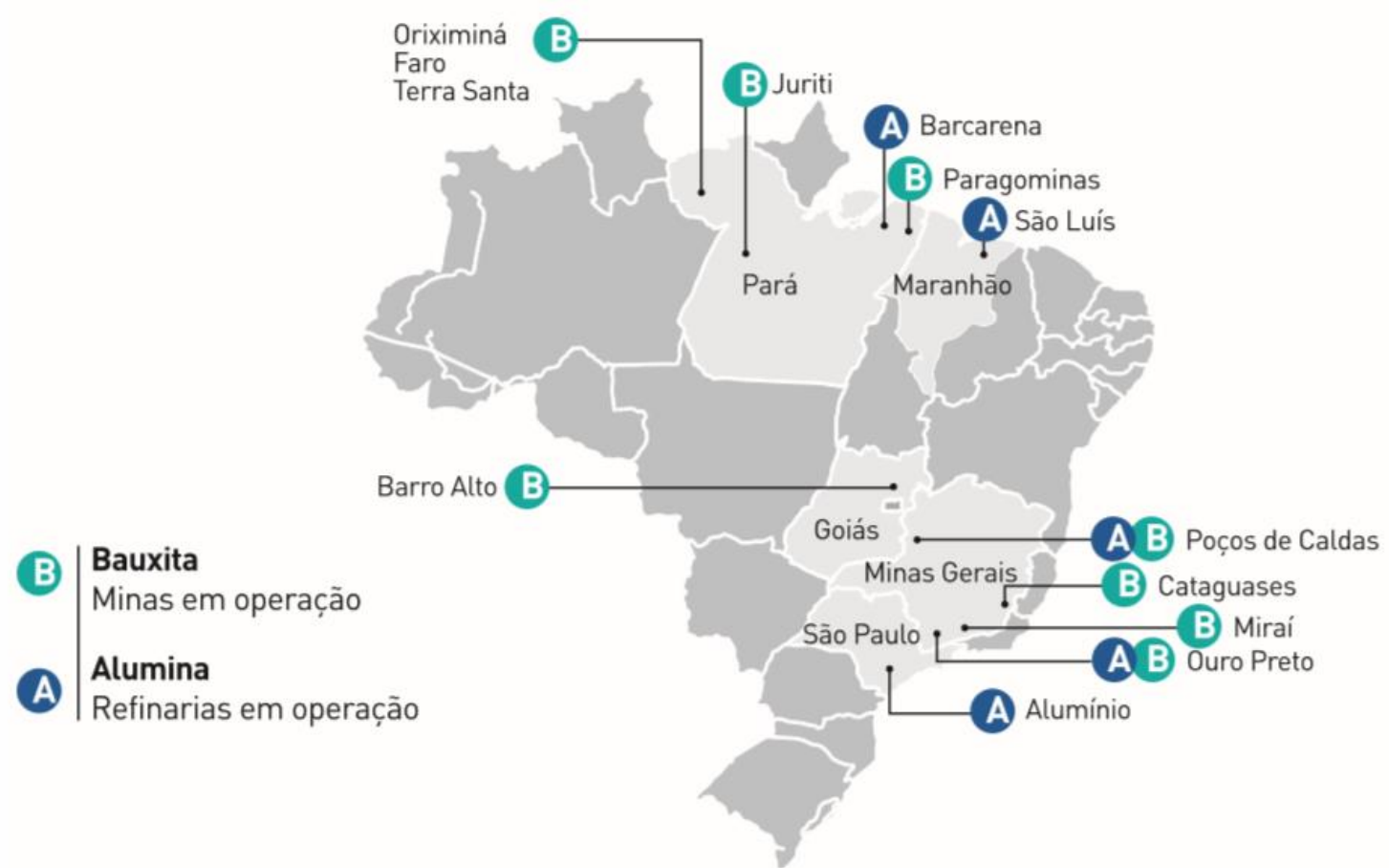

Figura 4-6 - Localização das minas de bauxita e refinarias de alumina no Brasil (Fonte: Associação Brasileira de Alumínio - ABAL, 2017)

A Figura 4-7 mostra a participação em porcentagem das principais empresas mineradoras na produção de bauxita beneficiada. No estado de Pará, por concentrar as maiores reservas do Brasil, estão instaladas as maiores mineradoras de bauxita, sendo estas Mineração Rio do Norte (com suas 
operações nas localidades de Oriximiná, Faro e Terra Santa), Mineração Paragominas (Norsk Hydro Brasil), Alcoa em Juruti. A Votorantim metais (Companhia Brasileira de Alumínio - CBA), prevê a implantação nos próximos anos do complexo industrial Alumina Rondon no estado do Pará.

Já no estado de Minas Gerais, a Votorantim Metais opera nos municípios de Miraí e Poços de Caldas e por enquanto encerrou as atividades de extração e beneficiamento no município de Itamarati de Minas. A mineradora Hindalco é de capital indiano e atua na região de Ouro Preto em Minas Gerais; já a mineradora Santo Expedito opera na região de Barro Alto em Goiás.

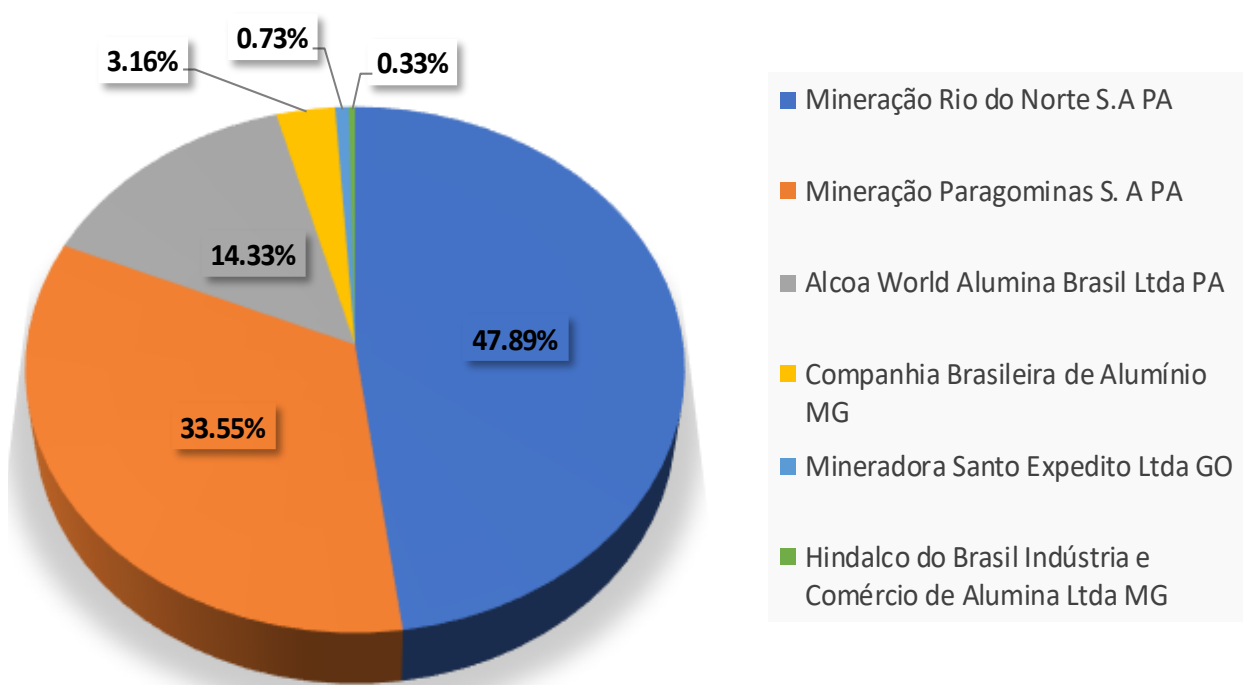

Figura 4-7 - Principais empresas produtoras de bauxita beneficiada no ano 2015 (Fonte: DNPM - Anuário mineral brasileiro, 2016).

\subsection{Gênese da bauxita de Miraí}

As jazidas do cinturão aluminoso de bauxita da Zona da Mata de Minas Gerais, se concentram numa faixa SW-NE localizada no sudeste de Minas Gerais. Sua extensão é aproximadamente de $160 \mathrm{~km}$ por $30 \mathrm{~km}$, ocorrendo entre as cotas 700-900 m, é considerada como uma das maiores jazidas de bauxita do Brasil. (e.g. Lopes e Branquinho, 1988; Silva,2015). Este cinturão se inicia no município de São Joao de Nepomuceno, atravessando os municípios de Miraí, Muriaé, chegando ao sul do Espirito Santo.

No começo da década de 70 , as jazidas de bauxita da região da Zona da Mata de Minas Gerais começaram a ser investigadas, inicialmente pela Industria Química de Cataguases e a Companhia de Alumínio Poços de Caldas. Estas 
jazidas apesar de apresentarem teores em alumina aproveitável baixos, também apresentavam teores de sílica reativa baixos, sílica na forma do argilomineral caulinita, o que significava um menor consumo de soda cáustica no estágio de refinamento no processo Bayer. Além disto, estas jazidas tinham uma localização geográfica privilegiada, o que fez que estes depósitos se tornassem atrativos para a mineração.

Em 1980, a Companhia Brasileira de Alumínio (CBA), atual Votorantim Metais, iniciou um amplo programa de pesquisa na região. Uma destas regiões pesquisadas com depósitos de bauxita, se localiza a $24 \mathrm{~km}$ ao nordeste do município de Miraí, cuja localização que pode ser vista na Figura 4-8.

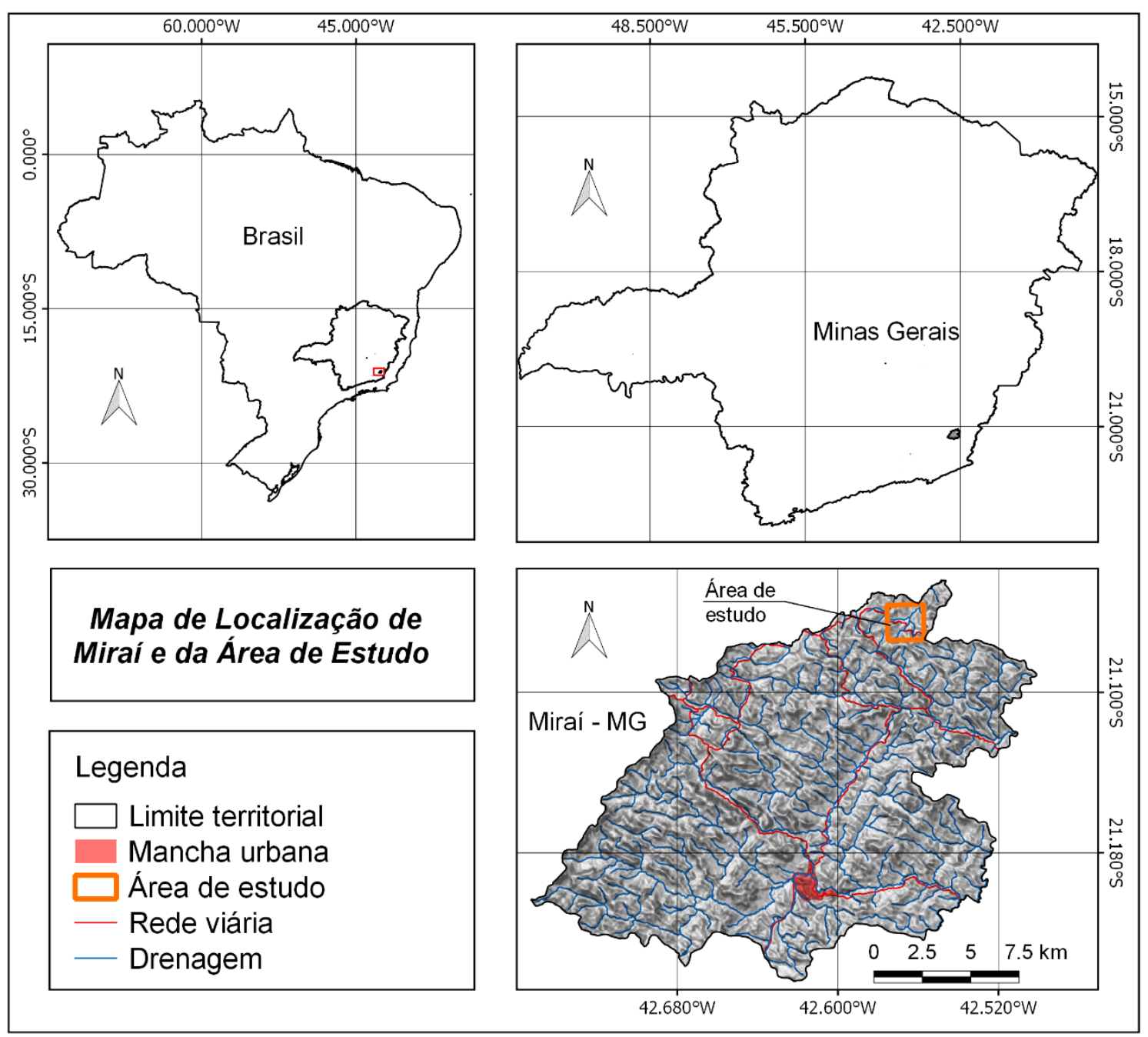

Figura 4-8 - Localização do Município de Miraí no estado de Minas Gerais

Estes depósitos foram formados a partir de alterações lateríticas (laterização) de granulitos da idade pré-cambriana do "Complexo Juiz de Fora" (e.g. Lopes,1987; Lopes \& Branquinho,1988; Lopes e Carvalho, 1990). 
A Figura 4-9 apresenta o mapa geológico da área da Mineração Miraí, elaborado com base no mapa geológico da Folha de Ubá 1:100.000 de Noce et al (2002), em cuja litologia há predominância de fáceis granulíticas representadas por gnaisses enderbiticos, charnockitos, granitoides, dioritos, gabros e noritos associados a gnaisse granuliticos e migmatitos (Melfi,1997; Romano e Castañeda,2006). Segundo Chaves (2009), partículas com granulometria maior que $0.35 \mathrm{~mm}$ possuem a mesma assembleia mineralógica e as frações mais finas da bauxita de origem gnáissico são em geral ricas em quartzo.

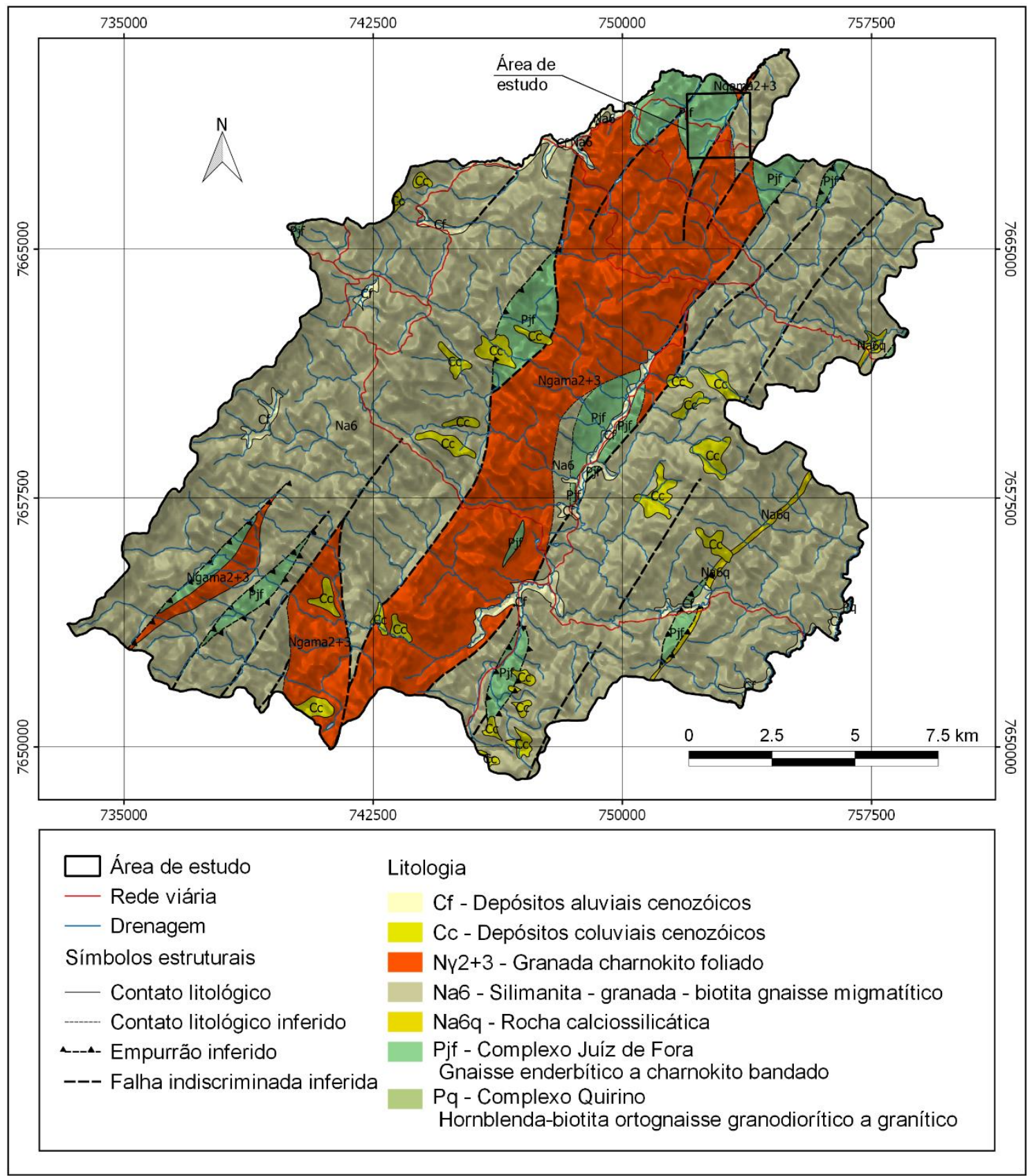

Figura 4-9 - Mapa Geológico da área em estudo (Fonte: Modificado de Noce et al, 2002) 
Segundo Lopes e Carvalho (1990), a bauxita ocorre nos topos e nas encostas superiores de morros meia-laranja, em altitudes próximas a $800 \mathrm{~m}$ como visto nas toposequências apresentadas na Figura 4-10 que definem duas zonas de alteração. A bauxita se apresenta na forma de fragmentos tabulares amarelados e rosa, com estrutura foliada da rocha conservada.

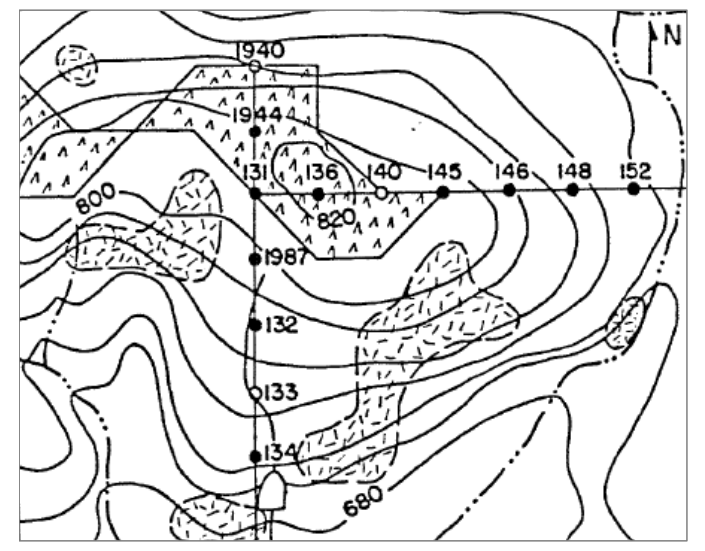

$\therefore A$ RESERVA DE BAUXITA MEDIDA

图 ROCHA

- PERFIS AMOSTRADOS
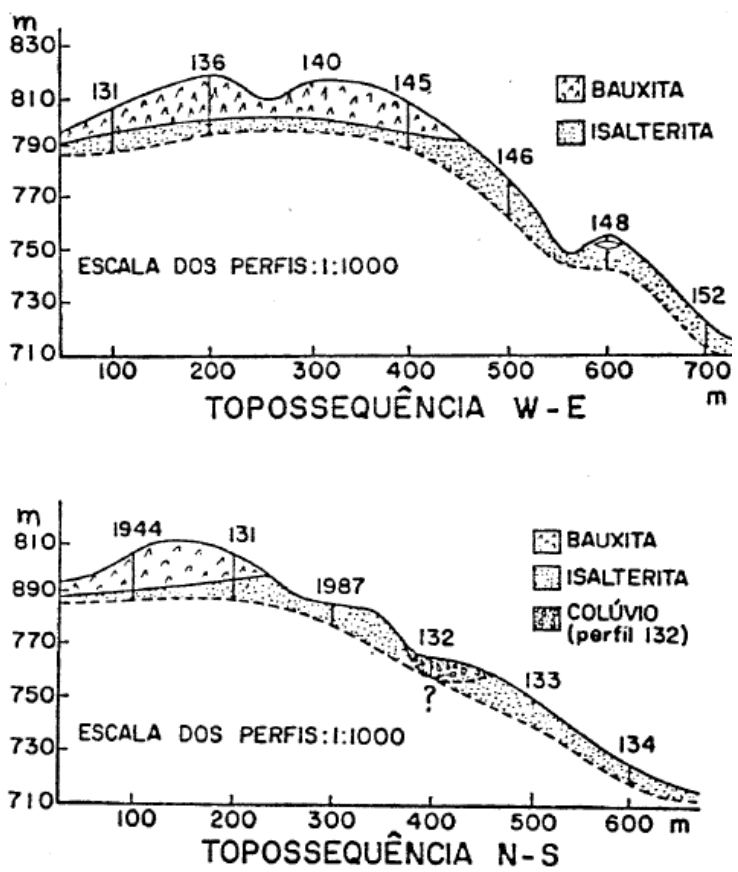

Figura 4-10 - Toposequências da área de Miraí (Fonte: Modificado de Lopes, 1987)

As duas zonas de alteração e suas fáceis podem ser vistas no perfil apresentado na Figura 4-11.

Como visto, estas duas zonas de alteração são:

- Bauxita com duas fáceis: bauxita isalteritica e bauxita aloteritica) e;

- Saprolito tendo como fáceis: isalterita gibbsitica e isalterita caolinitica 


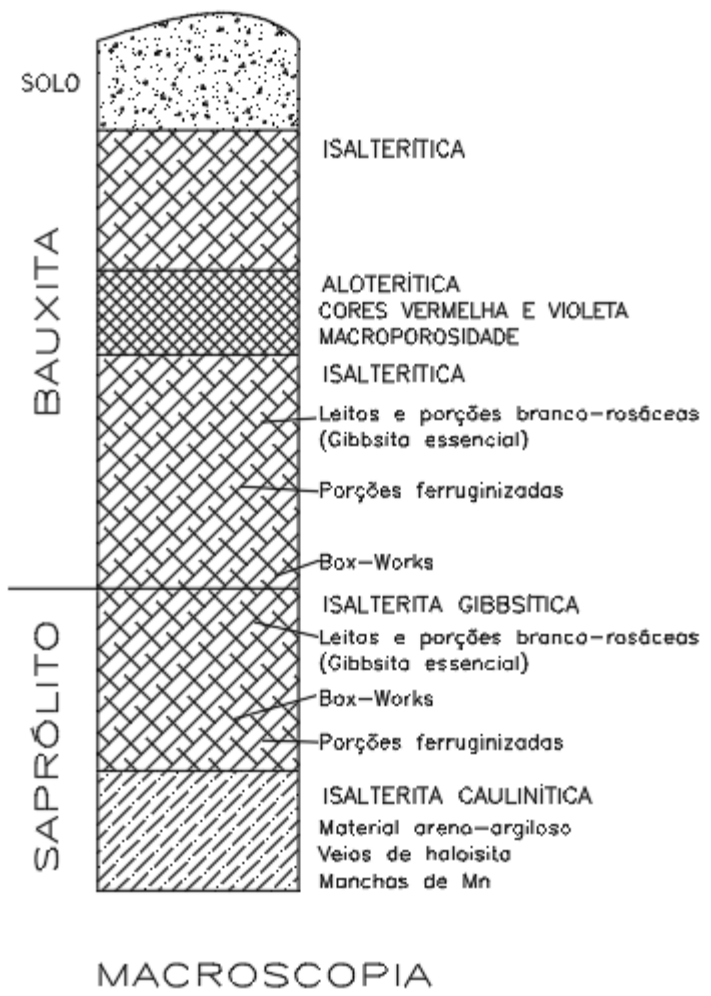

Foliação Conservada

Estrutura da Rocha não Conservada

Figura 4-11 - Fáceis de alteração de um perfil da área de Miraí (Fonte: Lopes e Carvalho, 1990)

\subsection{Produção de Alumina e Alumínio}

Segundo Valeton (1972), para que um depósito de bauxita seja considerado economicamente viável, deve conter ao menos de $45-50 \%$ de alumina $\left(\mathrm{Al}_{2} \mathrm{O}_{3}\right)$ e no mais de $20 \%$ de oxido de ferro na forma de hematita $\left(\mathrm{Fe}_{2} \mathrm{O}_{3}\right)$ ou goethita $(\mathrm{FeO})$ e $3 \%$ de sílica $\left(\mathrm{SiO}_{2}\right)$.

Como visto, a principal matéria prima para obtenção de alumínio é o minério bauxita. Geralmente, o processo de produção de alumínio primário no mundo envolve três grandes estágios:

- Mineração do minério bauxita (no capitulo 05 se explica com maiores detalhes este estágio).

- Refinamento do minério bauxita por meio do processo Bayer para obter alumina $\left(\mathrm{Al}_{2} \mathrm{O}_{3}\right)$ e;

- O processo de redução eletrolítica Hall-Herault da alumina para obtenção do alumínio primário.

Mais de $90 \%$ da produção de bauxita no ano 2016 foi convertido em alumina (USGS,2017), os 10\% restantes foram para a produção de produtos não 
metalúrgicos sejam: abrasivos, produtos químicos e refratários. No caso da alumina, $70 \%$ foi destinada para fabricação do alumínio primário, os $30 \%$ restantes para uso não metalúrgico (p. ex. cerâmicas).

A produção mundial de alumina no ano 2016 atingiu 118 Mt, sendo o maior país produtor de alumina no mundo a China com 58.5 Mt (praticamente mais de 50\% da produção mundial de alumina), seguido da Austrália com 20.7 Mt. Já o Brasil é o terceiro maior produtor com 10.8 Mt (USGS,2017).

A bauxita metalúrgica é aquela que vai para o processo Bayer. A produção de bauxita metalúrgica para o ano 2014 no Brasil representou quase $98 \%$ do total de minério bauxita beneficiado produzido naquele ano (DNPM,2015).

Chaves (2012) cita alguns conceitos necessários para melhor entendimento do processo operacional para o refino da bauxita

- A alumina $\left(\mathrm{Al}_{2} \mathrm{O}_{3}\right)$ extraída do processo Bayer tem a denominação alumina aproveitável (AA).

- A sílica pode estar presente no minério sob duas formas seja: O quartzo $\mathrm{SiO}_{2}$ cristalizado (sílica insolúvel - $\mathrm{SI}$ ) ou argilominerais (sílica reativa $\mathrm{SR}$ ) na forma de caulinita $\left(\mathrm{Al}_{2} \mathrm{O}_{3} .2 \mathrm{SiO}_{2} .2 \mathrm{H}_{2} \mathrm{O}\right)$. O nome reativo se deve a que a sílica reage com a soda caustica durante a etapa de digestão do processo Bayer. Consumindo soda e roubando alumina, a sílica reativa, forma um composto denominado sodalita, tornando o processo menos eficiente já que a remoção deste é problemático. A soda representa um investimento significativo e a formação de sodalita aumenta seu consumo, o que implica em maiores custos de produção. Com isto, a importância da remoção dos argilominerais durante o beneficiamento torna-se crucial no processo Bayer já que a Alumina aproveitável (AA) é a alumina total separada da alumina presente nos argilominerais. A sílica na forma de quartzo não afeta o processo Bayer.

- Impurezas como: Oxidos de ferro e titânio não reagem com a soda caústica, estas se precipitam para formar o resíduo denominado: Lama vermelha (red muds). Estas impurezas, assim como o quartzo diluem a AA diminuindo seu teor. 


\subsubsection{Processo Bayer}

O processo Bayer é um processo hidrometalúrgico para extrair alumina calcinada da bauxita beneficiada e foi desenvolvido pelo austríaco Karl Josef Bayer em 1888 (Anjier e Anderson,2014; Lumley 2011, Parekh e Goldberg 1976).

A partir do processo desenvolvido por Louis Le Chatelier em 1855 no qual este misturava carbonato de sódio $\left(\mathrm{Na}_{2} \mathrm{CO}_{3}\right)$ e bauxita aquecidas a $1200^{\circ} \mathrm{C}$ para obtenção de $\mathrm{Al}(\mathrm{OH})_{3}$, Bayer observou que ao aplicar soda caustica $(\mathrm{NaOH})$ no lugar de carbonato o processo se tornava mais eficiente e econômico. Bayer constatou que, por meio do aquecimento da bauxita com a solução de soda caustica, os componentes de alumínio se dissolviam e produziam o composto aluminato de sódio $\left(\mathrm{NaAl}_{2}\right)$, os componentes de ferro que não foram dissolvidos eram facilmente filtrados deixando o aluminato mais puro. Esta simples descoberta do Bayer, seria a base para o atual estágio de digestão das refinarias de alumina.

O princípio básico deste processo é dissolver o componente de alumínio da bauxita beneficiada na solução de soda caustica. Inicialmente esta solução é tratada para remover as impurezas como sílica e ferro. Finalmente é precipitada a alumina tri-hidratada, material que produz o $\mathrm{Al}_{2} \mathrm{O}_{3}$, conhecido como alumina.

A continuação se apresenta um breve resumo sobre os principais estágios do processo Bayer.

\subsubsection{Digestão}

É um processo de lixiviação aonde uma solução quente de soda cáustica $(\mathrm{NaOH})$ é usada para dissolver os minerais que levam alumínio no minério bauxita sob condições de temperatura, pressão e concentração de soda, as quais variam de acordo com as propriedades da bauxita (Filho et al, 2007), isto para formar uma solução supersaturada de aluminato de sódio $\left(\mathrm{NaAl}_{2}\right)$.

No caso da gibbsita (eq. 01) e boehmita e diásporo (eq. 02) a dissolução é descrita pelas equações:

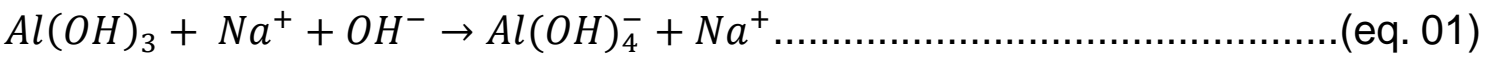

$$
\begin{aligned}
& \mathrm{AlO}(\mathrm{OH})+\mathrm{Na}^{+}+\mathrm{OH}^{-}+\mathrm{H}_{2} \mathrm{O} \rightarrow \mathrm{Al}(\mathrm{OH})_{4}^{-}+\mathrm{Na}^{+}
\end{aligned}
$$

Van Deursen (2016), explica que as temperaturas utilizadas para solubilização dos minerais existentes no minério bauxita dependem da proporção entre a 
gibbsita, boehmita e diásporo. O processo Bayer é denominado de baixa temperatura, quando se trata de solubilização de gibbsita, aonde a temperatura é aproximadamente $150^{\circ} \mathrm{C}$, no caso da alumina mono-hidratada (diásporo e boehmita) a temperatura gira em torno de $250^{\circ} \mathrm{C}$ nesta situação o processo Bayer é denominado de alta temperatura. A $240^{\circ} \mathrm{C}$, a pressão é de aproximadamente $3,5 \mathrm{MPa}$ (Wao, 2003). A partir destas condições os minerais contendo alumínio se dissolvem, formando um licor verde (Filho et al, 2007).

A pesar de temperaturas elevadas sejam teoricamente mais vantajosas existe um, porém, já que a $250^{\circ} \mathrm{C}$ o quartzo e a caulinita, consideradas impurezas, tendem a se solubilizar, o que significa que, se uma quantia suficiente de sílica se solubiliza, esta se precipita na forma de sodalita Bayer, fixando íons de sódio na fase solida que serão eliminados. O processo passa a consumir mais soda caustica $(\mathrm{NaOH})$, sendo necessária sua reposição no processo.

As bauxitas do Brasil, por serem lateríticas, apresentam maioritariamente o mineral gibbsita na sua composição, e como visto a temperatura do processo Bayer varia entre $140^{\circ} \mathrm{C}$ a $150^{\circ} \mathrm{C}$ aonde somente se solubiliza a caulinita (Ostap,1986). No Brasil é comum separar este argilomineral no processo de beneficiamento.

\subsubsection{Clarificação}

Consiste em separar os sólidos insolúveis (resíduos de minério bauxita) do licor (aluminato de sódio em solução) por sedimentação. Floculantes são adicionados para auxiliar o processo de sedimentação. $O$ resíduo de minério bauxita se deposita no fundo dos tanques de decantação, depois é transferido para os tanques de lavagem, onde sofre uma série de fases de lavagem para recuperar a soda cáustica (que será reutilizado no processo de digestão).

A separação adicional entre o licor e o resíduo de minerio bauxita é realizada utilizando uma série de filtros de segurança. $O$ objetivo dos filtros de segurança é garantir que o licor clarificado não esteja contaminado com impurezas presentes no resíduo.

Este resíduo insolúvel é denominado lama vermelha formado por óxidos de ferro, titânio, quartzo, aluminossilicatos de sódio, minerais de ganga, e soda caustica arrastada (Kurusu, 2009). A lama vermelha é o maior resíduo do processo Bayer 
e é um dos grandes problemas ambientais do refino do minerio bauxita (Parekh e Goldberger, 1976)

Dependendo dos requisitos da instalação de armazenamento de lama vermelha, são empregados estágios de espessamento, filtração e / ou neutralização antes de serem bombeados para a área de disposição.

\subsubsection{Calcinação}

Esta é a etapa final do processo Bayer, aonde inicialmente a alumina é lavada para retirar qualquer vestígio de licor. A alumina hidratada é calcinada a temperaturas até $1100^{\circ} \mathrm{C}$ para eliminar água de hidratação, produzindo cristais de alumina pura, na forma de pó branco (Filho et al 2007; Hind et al, 1999; Massola, 2008; Kurusu 2009) o qual será encaminhado para fundições de alumínio primário (smelters) ou para a indústria química.

Existem diferentes tecnologias de calcinação em uso, incluindo calcinadores de suspensão de gás, calcinadores de leito fluidizado e fornos rotativos.

A equação 05 descreve a reação de calcinação:

$2 \mathrm{Al}(\mathrm{OH})_{3} \stackrel{\Delta}{\rightarrow} \mathrm{Al}_{2} \mathrm{O}_{3}+3 \mathrm{H}_{2} \mathrm{O} \uparrow$

O fluxograma generalizado do processo Bayer está apresentado na Figura 4-12.

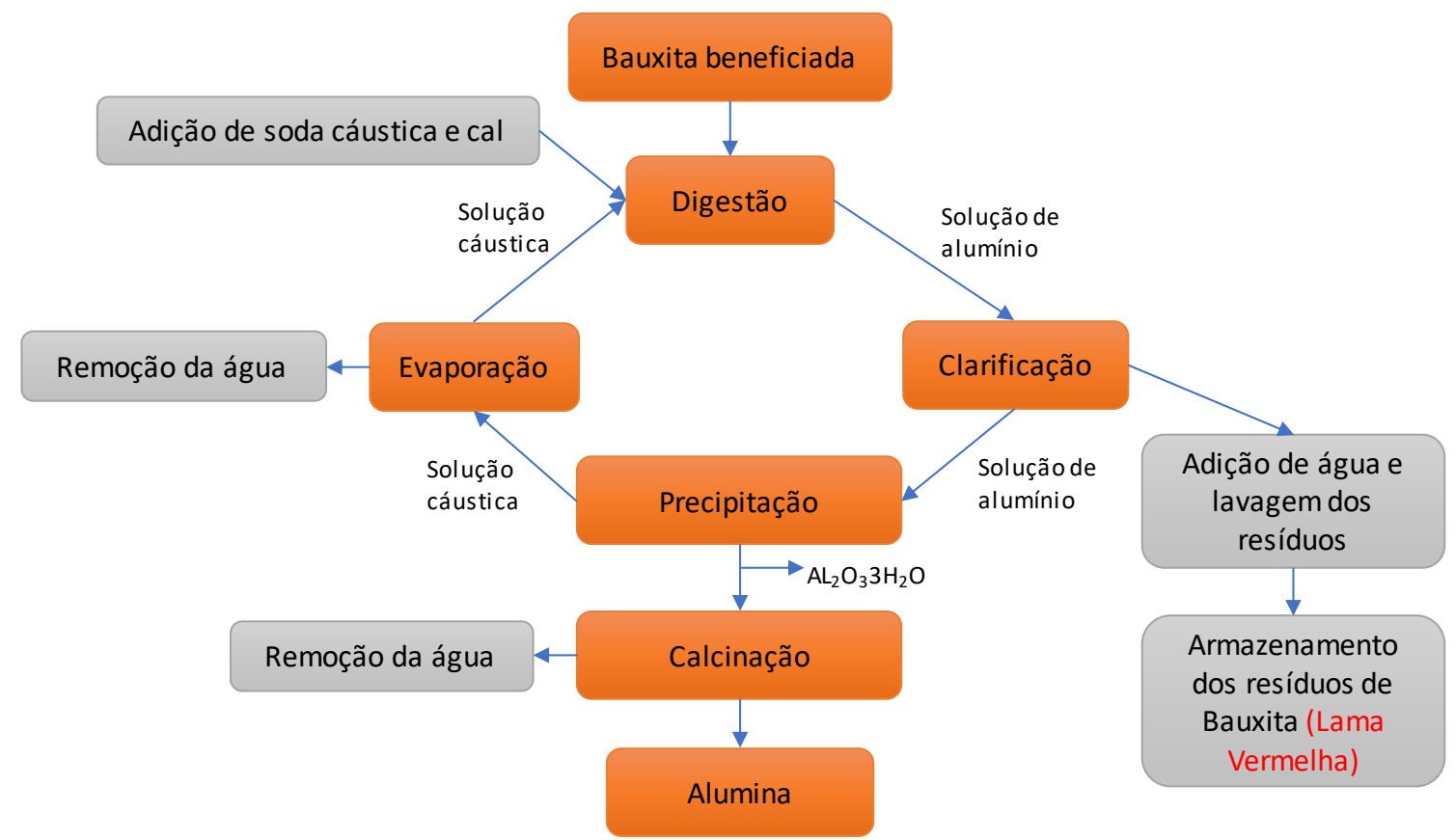

Figura 4-12 - Processo Bayer para obtenção da alumina. (Fonte: Modificado de Norsk Hydro, 2012) 


\subsubsection{Processo Hall-Herault}

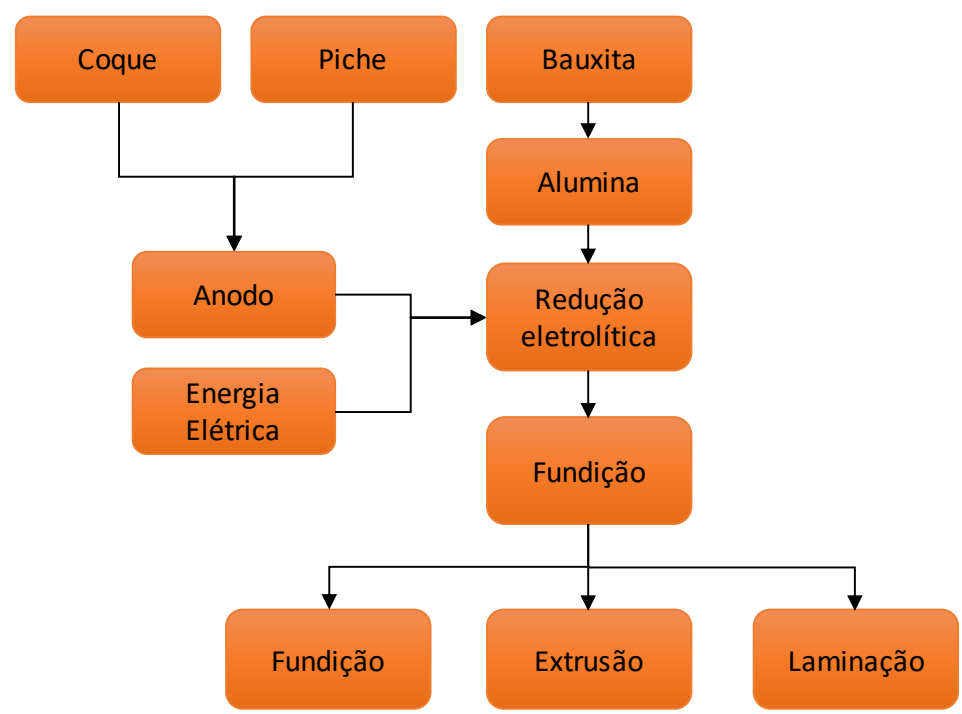

Figura 4-13 - Esquema do processo Hall-Herault para obtenção do alumínio primário. (Fonte: Norsk Hydro, 2012). 


\subsection{Rejeitos de Mineração}

Segundo Lottermoser (2007), as operações da indústria mineral incluem as seguintes atividades sequenciais: A lavra, o beneficiamento e a extração metalúrgica. A lavra é a primeira operação no processo de exploração comercial do bem mineral, basicamente é a extração do material proveniente do subsolo com o objetivo de retirar e recuperar somente o bem mineral. $\mathrm{O}$ beneficiamento visa separar e concentrar os minérios por meios físicos. Já na extração metalúrgica as ligações metálicas do minério beneficiado são destruídas de modo a extrair o metal desejado

Os rejeitos de mineração são em geral misturas com elevada presença de água, isto por causa do processo de lavagem que tem por objetivo separar a fração fina da fração grossa que contém na maioria das vezes o minério de interesse. O rejeito é comumente lançado por via hidráulica para estruturas de armazenamento sejam diques ou barragens. Vick (1983) os define como partículas provenientes da trituração de rochas, os quais são depositados na forma de lamas na sua maioria. Esta definição engloba os resíduos, sejam do beneficiamento ou processamento mineral, que sobraram após a extração dos minerais de valor econômico.

A Tabela 4-3 apresenta um resumo com os principais minerais extraídos no mundo, seu processamento e características granulométricas dos seus rejeitos. 
Tabela 4-3 Principais minerais, processamento e características dos seus rejeitos. (Fonte: Adaptado de Vick, 1983)

\begin{tabular}{|c|c|c|}
\hline Minério & Minerais & Processos Industriais \\
\hline & $\begin{array}{c}\text { Chumbo / } \\
\text { Zinco }\end{array}$ & $\begin{array}{l}\text { Estes metais são encontrados associados na } \\
\text { natureza e frequentemente são minerados juntos. A } \\
\text { concentração é obtida por flotação de galena e de } \\
\text { esfarelita. Os rejeitos são geralmente lamas de baixa } \\
\text { plasticidade e argilosas. }\end{array}$ \\
\hline & Ouro & $\begin{array}{l}\text { A recuperação hidrometalúrgica inclui a etapa de } \\
\text { lixiviação aonde é adicionado cianeto de sódio, que } \\
\text { lixivia e estabiliza o ouro em solução. Os elementos } \\
\text { que prevalecem no rejeito são o ferro, silício e em } \\
\text { menor quantidade o titânio e alumínio (Bedin,2010). }\end{array}$ \\
\hline Cuprita & Cobre & $\begin{array}{l}\text { O minério de cobre produzido é realizado em larga } \\
\text { escala a partir de cavas a céu aberto. A concentração } \\
\text { é obtida por flotação. O rejeito pode ter granulometria } \\
\text { grossa ou fina, a presença da fração grossa depende } \\
\text { de processos prévios de separação de areia por meio } \\
\text { de ciclones. Se não houver separação prévia o rejeito } \\
\text { tem comportamento não plástico. }\end{array}$ \\
\hline Garnierita & Níquel & $\begin{array}{l}\text { O processo de obtenção é por flotação e separação } \\
\text { magnética. Rejeitos de minério de níquel de origem } \\
\text { laterítica, podem conter alto grau de concentração de } \\
\text { argilas e micas. }\end{array}$ \\
\hline \multirow[t]{4}{*}{$\begin{array}{l}\text { Itabirito / } \\
\text { Hematita }\end{array}$} & Ferro & $\begin{array}{l}\text { O beneficiamento no Brasil se dá a partir de dois } \\
\text { minérios: itabirito, com teor baixo e hematitas com teor } \\
\text { elevado. Dependendo do minério de origem, dois tipos } \\
\text { de rejeito podem ser produzidos. A concentração a } \\
\text { partir do itabirito é por flotação que gera um rejeito de } \\
\text { granulometria silto-arenosa e do espessador de finos } \\
\text { se obtém uma lama silto-argilosa (Oliveira Filho } \\
\text { \&Abrão,2015) }\end{array}$ \\
\hline & Fosfato & $\begin{array}{l}\text { O minério esmagado é lavado e, com isto, retirada a } \\
\text { fração dos finos, que são descartados na forma de } \\
\text { lamas. O concentrado é obtido por flotação. A lama } \\
\text { tem granulometria predominantemente silto-argilosa. }\end{array}$ \\
\hline & Urânio & $\begin{array}{l}\text { Estes rejeitos têm propriedades radioativas. O minério } \\
\text { é processado por meio de técnica de lixiviação que } \\
\text { pode ser ácida ou básica dependendo da } \\
\text { porcentagem de carbonato do minério. Se não houver } \\
\text { separação da fração grossa os rejeitos são } \\
\text { considerados não plásticos. Se for lançada somente a } \\
\text { fração fina a plasticidade depende da porcentagem de } \\
\text { argila e a mineralogia da rocha mãe }\end{array}$ \\
\hline & Potássio & $\begin{array}{l}\text { O potássio é minerado a partir de depósitos } \\
\text { sedimentares, utilizado principalmente na composição } \\
\text { dos fertilizantes. Os rejeitos de potássio são } \\
\text { compostos por uma fração grossa com alto teor de sal } \\
\text { e uma fração fina com presença de argila. Este } \\
\text { efluente consiste numa salmoura salgada, que } \\
\text { quando disposta na barragem tem susceptibilidade de } \\
\text { ser solúvel. }\end{array}$ \\
\hline
\end{tabular}




\subsection{Rejeitos e resíduos de bauxita}

Como visto a bauxita é lavrada em minas a céu aberto principalmente em regiões tropicais e subtropicais. A literatura indica que em média são necessárias de 4 a 7 toneladas de minério bauxita beneficiado para produzir 02 toneladas de alumina que por sua vez produz 01 toneladas de alumínio. Cerca de 0.8-2.5 toneladas de resíduo de "red mud" são geradas por tonelada de produção de alumina. Globalmente, estima-se que mais de 120 milhões de toneladas de resíduos “red mud” estejam sendo gerados por ano (Redhy e Rao, 2016).

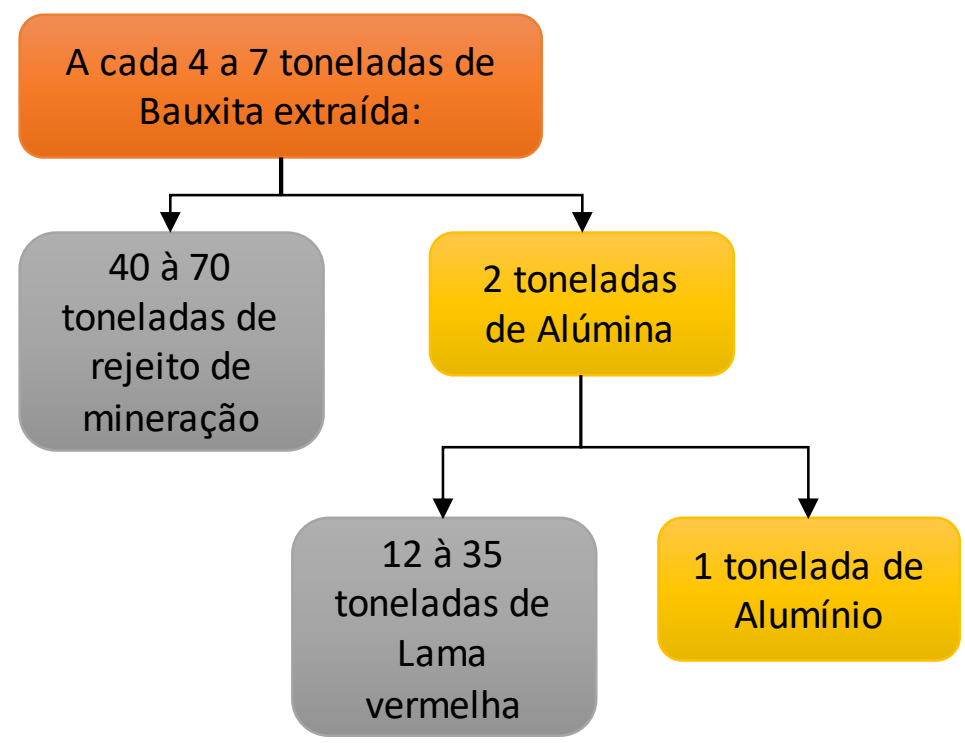

Figura 4-14 - Resíduos de mineração gerados pelo processo de obtenção do alumínio (Bournay et al, 2006)

A Figura 4-14 acima, ilustra a quantidade de resíduos de mineração gerados a partir da mineração de uma tonelada de bauxita que são: 10 toneladas de resíduo resultante da mineração de bauxita e 03 toneladas de "red mud" - lama vermelha procedente do refino da Bauxita pelo processo Bayer. Por tanto para uma tonelada de alumínio primário foram geradas 65 toneladas de resíduos.

A Figura 4-15 traz informações sobre as práticas de disposição de resíduos de 17 refinarias de alumina que no ano 2007 representavam 44\% da produção mundial de alumina. A figura mostra que a partir da década de setenta há uso crescente da técnica de empilhamento a seco. Em 1965, 37\% das refinarias despejavam seus resíduos no mar, já o restante os armazenava em diques ou barragens. Em 1970, com o aumento da produção surgiram pesquisas de novas alternativas de armazenamento, assim surgiram os métodos de empilhamento a seco. Em 1985 quase 50\% das refinarias já armazenavam seus resíduos por 
empilhamento a seco. Em 2007 observa-se a preferência de mais de 60\% de refinarias pelo empilhamento a seco e a desistência da prática de imersão marinha.

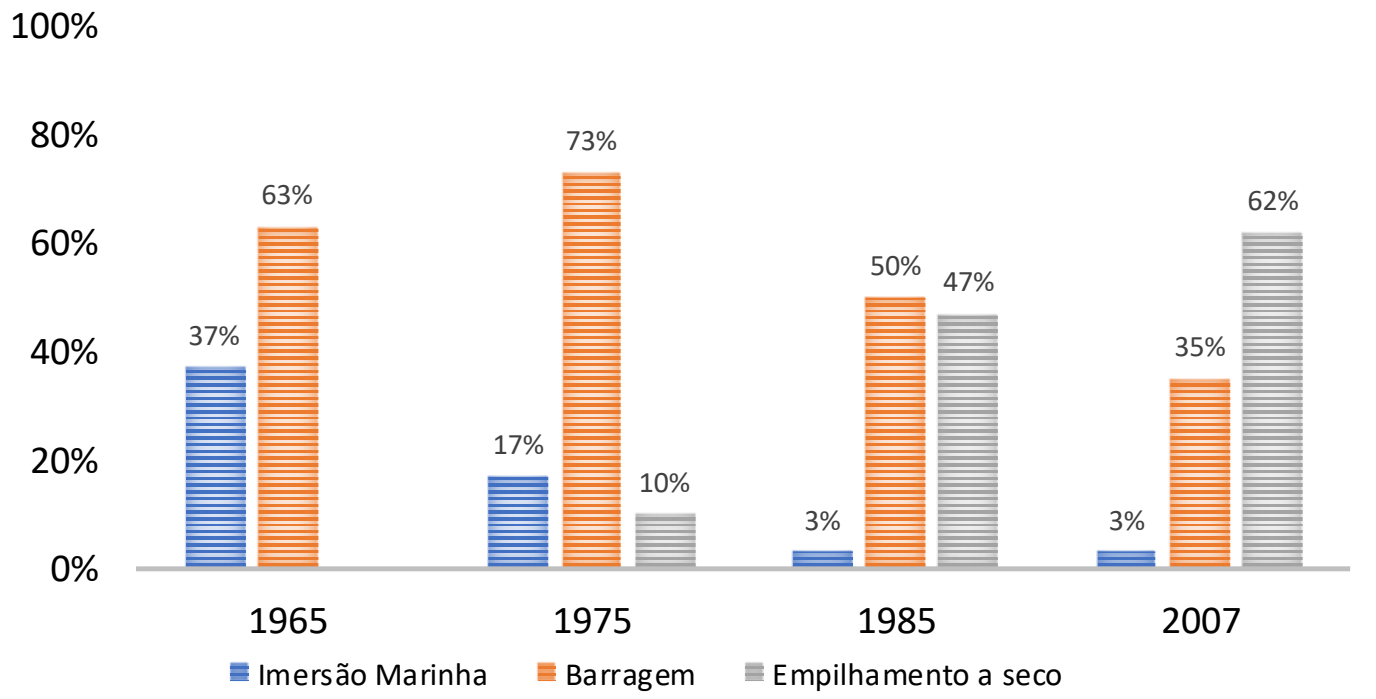

Figura 4-15 - Evolução histórica do processo de disposição da lama vermelha. (Fonte: Adaptado de Power et al 2009)

Segundo Power et al (2009), o uso da prática de empilhamento a seco se justifica principalmente devido a exigências econômicas e ambientais que levam a necessidade de:

- Redução de áreas para armazenamento de resíduos;

- Minimizar o potencial de liberação de soda cáustica no meio ambiente;

- Maximizar a recuperação da soda cáustica para seu uso na refinaria

Segundo van Deursen (2016) do total de bauxita pronta para refino produzida no mundo, estima-se que aproximadamente $25 \%$ desta produção seja de minério bauxita beneficiado (conhecido também no meio mineral como bauxita lavada) corresponde aos países de Brasil e Austrália ou seja aproximadamente 65 Mt de bauxita lavada.

Para uma média de recuperação mássica de $70 \%$ de $65 \mathrm{Mt}$ de bauxita beneficiada lavada, tem-se que o ROM (Run of mine) que é o material bruto lavrado corresponde a $93 \mathrm{Mt}$, por tanto havendo uma geração de $28 \mathrm{Mt}$ de material que corresponde ao rejeito em massa seca. Considerando-se, 60\% de sólidos (massa sólidos / massa total) como valor médio na disposição são 
representados pelos $28 \mathrm{Mt}$, se obtem aproximadamente $47 \mathrm{Mt}$ de rejeitos gerados no mundo na base úmida.

Se 54\% desses 47 Mt correspondem à produção brasileira, são gerados no Brasil, $25 \mathrm{Mt}$ de rejeitos, onde $15 \mathrm{Mt}$ de rejeito correspondem à base seca somados de $10 \mathrm{Mt}$ de água, quer dizer que para 01 tonelada de rejeito de bauxita lavada na base seca no brasil são necessárias 0.67 tonelada de água.

A seguir apresentasse na tabela algumas quantidades de produção de rejeitos levantadas de mineradoras no Brasil (van Deursen, 2016).

Tabela 4-4 Quantidade de rejeitos gerados a partir da produção de bauxita lavada Exemplos de mineradoras no Brasil. (Fonte: van Deursen, 2016)

\begin{tabular}{ccccc}
\hline Mineradora & $\begin{array}{c}\text { R.O.M } \\
\text { Lavrado } \\
(\mathbf{M t})\end{array}$ & $\begin{array}{c}\text { Bauxita } \\
\text { Beneficiada } \\
(\mathbf{M t})\end{array}$ & $\begin{array}{c}\text { Rejeito } \\
\text { Seco } \\
(\mathbf{M t})\end{array}$ & $\begin{array}{c}\text { Rejeito na } \\
\text { base úmida } \\
\text { (Mt) }\end{array}$ \\
\hline $\begin{array}{c}\text { MRN - Oriximá } \\
\text { / 2012 }\end{array}$ & 25.7 & 18.0 & 7.7 & 14.0 \\
$\begin{array}{c}\text { Norsk Hydro - } \\
\text { Paragominas / }\end{array}$ & 13.14 & 9.2 & 3.9 & 6.6 \\
$\begin{array}{c}\text { 2015 } \\
\text { CBA - Miraí / }\end{array}$ & 7.5 & 3.0 & & \\
2008 & & 4.5 & 10.0 \\
\hline
\end{tabular}

A partir das informações contidas na Tabela 4-4, observa-se que, para as minerações de Oriximá para 01 tonelada de R.O.M lavrado será gerada 0.5 tonelada de rejeito, para a Paragominas 0.54 tonelada. Já no caso da Mineração Miraí, para 01 tonelada de R.O.M lavrado são geradas aproximadamente 1.33 toneladas de rejeito.

\subsection{Caracterização Mineralógica}

Os teores médios encontrados por Carvalho (1989) para a reserva de Miraí, mostram que a presença de oxido de alumínio é na ordem de $42 \%$ e mineralogia constituída basicamente por gibsita e goethita, hematita e quantidades de quartzo e caulinita, conforme Tabela 4-5. 
Tabela 4-5 Análise mineralógica por fluorescência de raio $X$ de reservas de bauxita de Miraí. (Carvalho, 1989).

\begin{tabular}{ccccccccc}
\hline & $\mathrm{SiO}_{2}$ & $\mathrm{Al}_{2} \mathrm{O}_{3}$ & $\mathrm{Fe}_{2} \mathrm{O}_{3}$ & $\mathrm{TiO}_{2}$ & $\mathrm{CAOL}$ & $\mathrm{GIBB}$ & OX.Fe & ANAT \\
\hline $\begin{array}{c}\text { BAUXITA } \\
\text { ISALTERÍTICA }\end{array}$ & 10.2 & 44.7 & 15.8 & 3.3 & 22.9 & 57 & 16.7 & 3.4 \\
$\begin{array}{c}\text { BAUXITA } \\
\text { ALOTERÍTICA }\end{array}$ & 5 & 40.6 & 24 & 4.8 & 11.4 & 57.7 & 25.9 & 5.1 \\
$\begin{array}{c}\text { BAUXITA } \\
\text { ISALTERÍTICA }\end{array}$ & 5.6 & 39.8 & 23.4 & 4.2 & 13 & 57.7 & 25.7 & 4.5 \\
\hline \begin{tabular}{c} 
ISALTERITA \\
\hline
\end{tabular} & 15.2 & 33.7 & 23.8 & 4.9 & 35.3 & 33.5 & 26 & 5.3 \\
\hline
\end{tabular}

4.9 Propriedades geotécnicas dos rejeitos e resíduos da indústria mineral

Uma série de fatores estão envolvidos no comportamento e natureza dos rejeitos, podendo ser nomeados: o minério lavrado que the deu origem, os processos de tecnologia mineral (beneficiamento e de refinaria) envolvidos para extrair o material com valor econômico. A evolução dos processos da tecnologia mineral vem a ser um fator determinante, que pode gerar variações significativas nas características do rejeito com o passar do tempo.

Também se deve levar em conta a forma de disposição para o armazenamento de rejeito, um exemplo é o uso de ciclones, que separa o rejeito fino (overflow), do rejeito grosso (underflow), faz com que as características sejam diferentes.

Em termos de engenharia geotécnica, as propriedades a serem estudas do rejeito compactado são:

- Distribuição granulométrica

- A densidade de compactação e seu teor de umidade.

- A condutividade hidráulica associada ao estado de compactação.

- As características de compressibilidade do material compactado.

- A resistência ao cisalhamento não drenado.

- O potencial de liquefação do material inferido de diferentes formas.

- O estado não saturado 


\subsubsection{Distribuição Granulométrica}

Existe uma vasta gama de curvas granulométricas para rejeitos provenientes de diversas operações de extração de minério. As granulometrias dos rejeitos podem variar entre os diâmetros das areias e das argilas. Para Sarsby (2013), a granulometria dos rejeitos depende do grau de trituração das partículas devido à britagem assim como também o teor de argila contido no minério de origem.

Para Fell et al (2015) a distribuição granulométrica de rejeitos oxidados (por exemplo, ouro, cobre) e rejeitos de lavagem (por exemplo, sais de cobre, minério de ferro, bauxita) depende da metodologia do ensaio utilizado e os dispersantes que são adicionados. A Figura 4-16 mostra cinco curvas granulométricas de rejeitos de origem australiana sendo: Duas de ferro (Newman e Hamersley), duas de carvão (Wambo e Riverside), e um para rejeito de bauxita - lama vermelha (Weipa). A Figura 4-12a mostra que sem a ação dos dispersantes os rejeitos mostram a granulometria de uma areia siltosa, já a figura 4-12b apresenta a ação do dispersante sobre os rejeitos e se observa que as curvas granulométricas correspondentes apresentam frações que correspondem as argilas. 

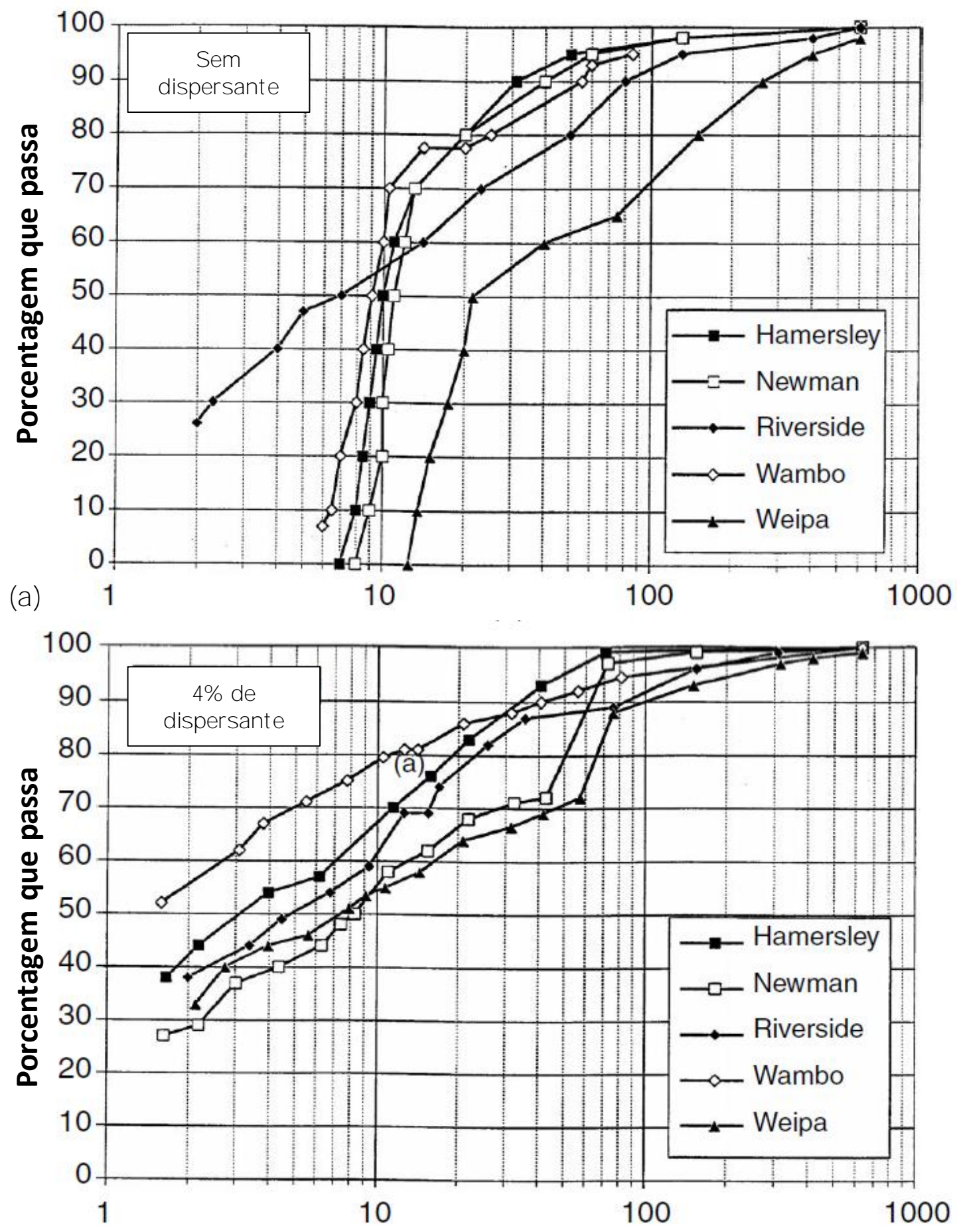

(b)

Diâmetro das partículas $(\mu \mathrm{m})$

Figura 4-16 - Distribuição granulométrica de rejeitos de lavagem provenientes da Australia. (a) Sem dispersante. (b) Com dispersante. (Fell et al 2015)

A Figura 4-17 apresenta curvas granulométricas de alguns resíduos de mineração apresentados por Fourie (1999). A curva da Bauxita se refere à granulometria do resíduo do processo Bayer. 


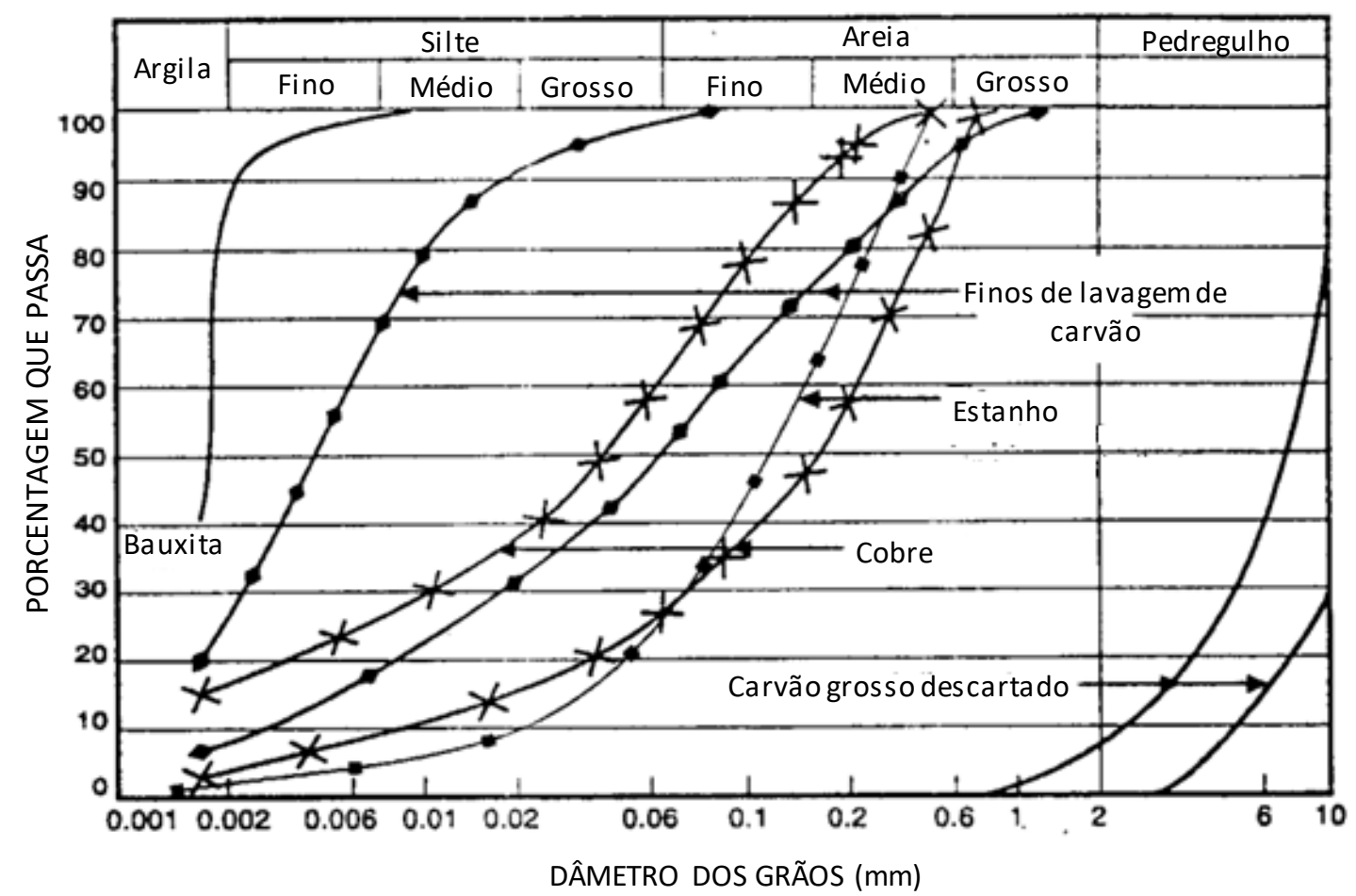

Figura 4-17 - Curvas granulométricas de alguns rejeitos de mineração Fourie (1999).

Embora seja necessária uma completa caracterização dos rejeitos, a simples observação da curva granulométrica permite fazer algumas observações relacionadas ao comportamento esperado para o material. No caso da lama vermelha por exemplo, que possui um teor de material fino muito alto, espera-se que o material apresente baixa condutividade hidráulica e plasticidade. Conforme observado por Vick (1983) estes materiais possuem uma resistência muito baixa quando lançado hidraulicamente. A associação destas propriedades sugere um material com baixa capacidade de drenagem o que afeta a linha freática e consequentemente pode causar problemas de estabilidade.

As características granulométricas do rejeito de bauxita sem ter sido submetido ao processo Bayer, não são facilmente encontradas na literatura. Tem-se referência apenas à lama vermelha.

Li (1998), investigou os efeitos de diversas temperaturas e concentração de soda cáustica no processo de digestão da bauxita sobre o comportamento de sedimentação e as características físicas, químicas e mineralógicas da lama vermelha procedente da Jamaica. Os resultados obtidos por Li (1998) para distribuições granulométricas podem ser vistos na Figura 4-18, aonde se observa que as amostras digeridas com a mesma temperatura se mostram semelhantes 
na distribuição granulométrica no caso das amostras JHM1 E JHM3 apresentando também uma maior porcentagem de finos.

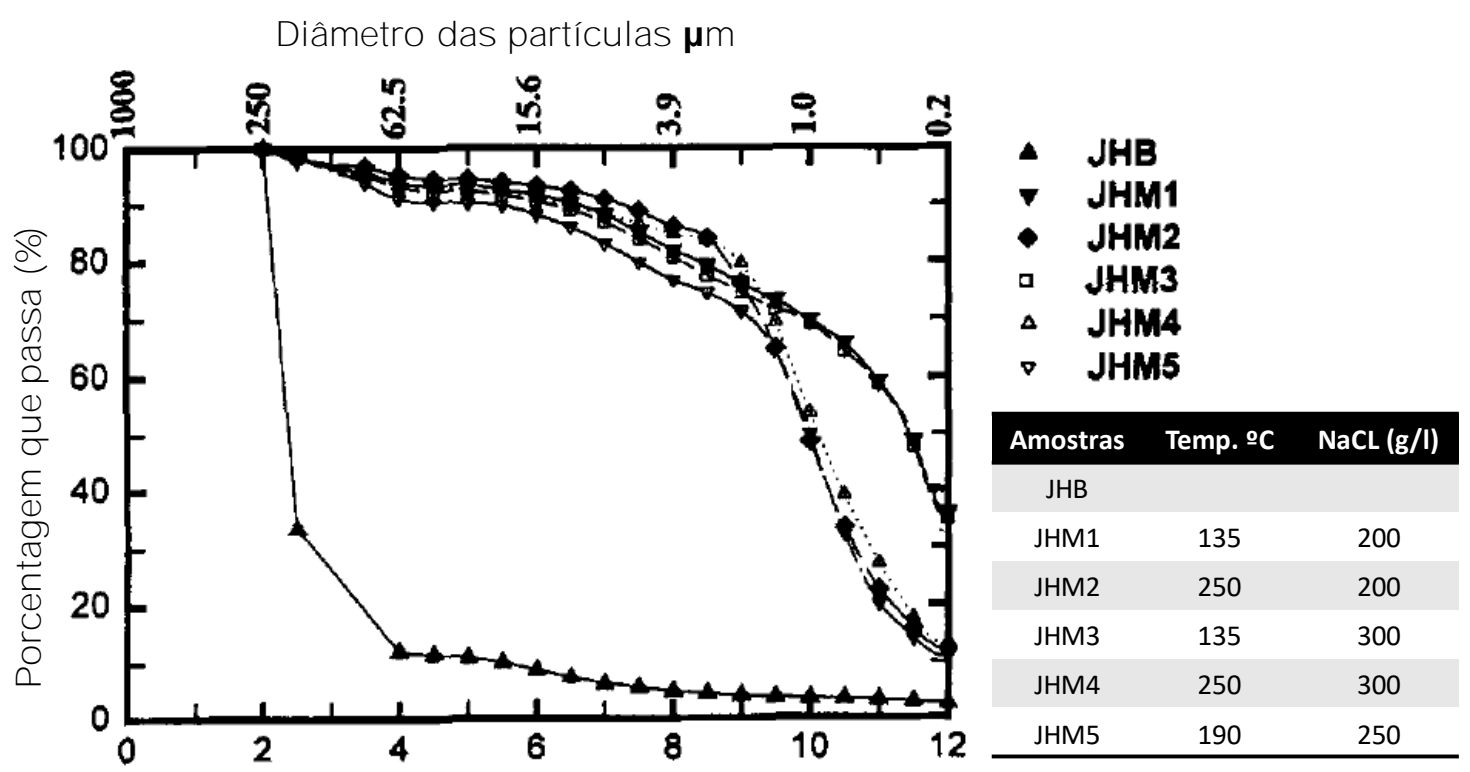

Figura 4-18 - Curvas granulométricas de bauxita e lama vermelha de Jamaica para diversas temperaturas de digestão e concentração de soda cáustica (Adaptado de Li, 1998).

Na Figura 4-19 estão apresentadas curvas granulométricas, apresentados por Rout et al. (2013), de um rejeito de bauxita após o processo Bayer (lama vermelha), comparado com cinzas e o solo do local de extração da bauxita (cidade de Damanjodi, India).

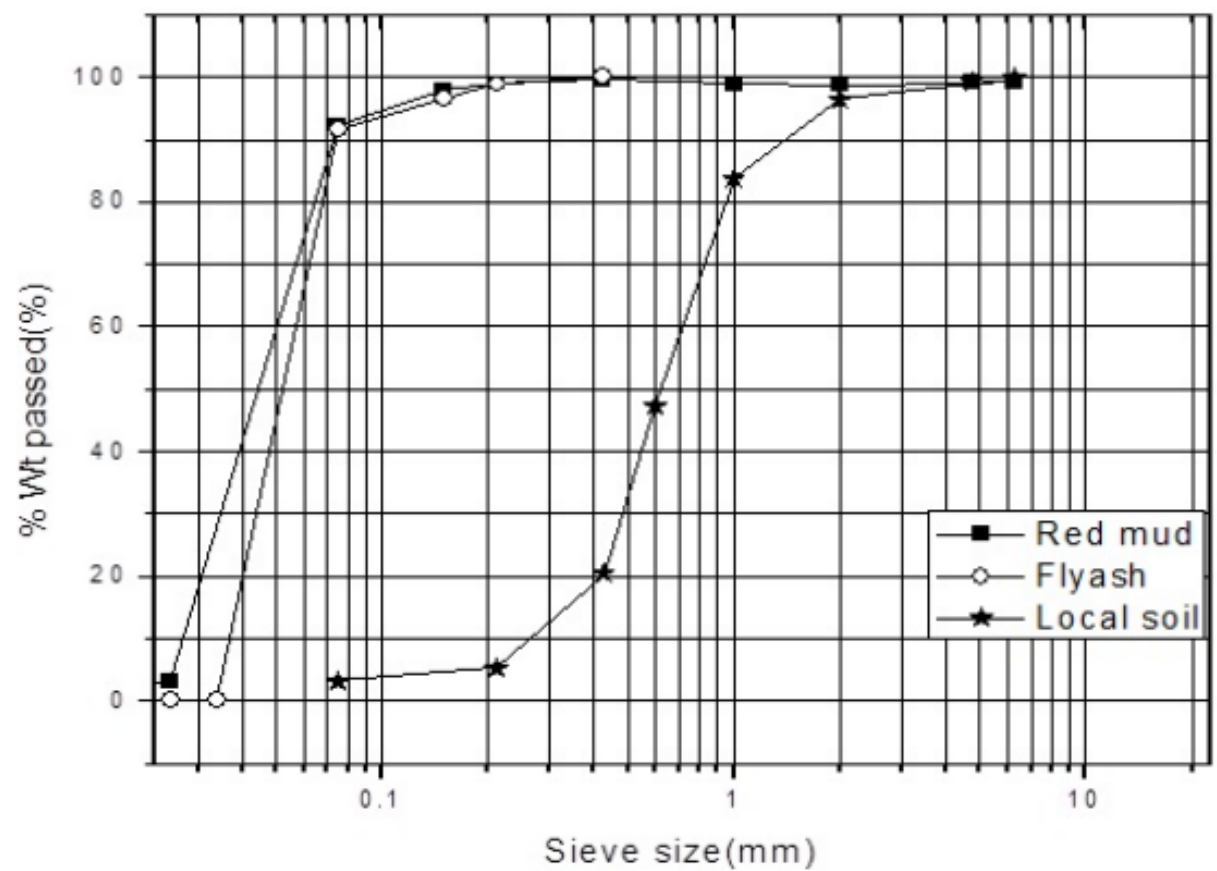

Figura 4-19 - Curvas granulométricas de lama vermelha, cinzas e solo da cidade de Damanjodi, India (Rout et al., 2013). 


\subsubsection{Densidade dos grãos}

A densidade específica varia amplamente e depende da quantidade de ferro presente (Vick,1983).

A Tabela 4-6 apresenta valores de densidade dos grãos de lama vermelha obtidas por diversos autores.

Tabela 4-6 Valores de densidade dos grãos para lama vermelha.

\begin{tabular}{|c|c|c|c|}
\hline Localização & $\begin{array}{c}\rho_{s} \\
\left(g / \mathrm{cm}^{3}\right)\end{array}$ & Observações & Autor \\
\hline Jamaica & 3.65 & $\begin{array}{c}\text { Amostras coletadas na } \\
\text { lagoa do dique. Amostra } \\
\text { seca na estufa }\end{array}$ & Gore, 2015 \\
\hline Singaredi- Guiné & 3.41 & $\begin{array}{l}\text { Resíduo empilhado a } \\
\text { seco "dry-stacking" - } \\
\text { Amostra seca na estufa }\end{array}$ & Gore, 2015 \\
\hline Renukoot - India & 3.04 & & Deelval et al, 2014 \\
\hline Odisha-India & 3.34 & & Rout et al, 2013 \\
\hline Pará Brasil & 2.67 & & Pedrosa, 2012 \\
\hline Brasil & $2.75-3.5$ & & Bedin, 2006 \\
\hline Brasil & 2.9 & & $\begin{array}{l}\text { De Mello e Silveira, } \\
2003\end{array}$ \\
\hline Brasil & 2.96 & & Villar, 2002 \\
\hline Jamaica & $2.9-3.0$ & & Stinson, 1981 \\
\hline Africa & $2.9-3.0$ & & Stinson, 1981 \\
\hline Estados Unidos & 2.8-3.3 & & $\begin{array}{c}\text { Somogyi \& Gray, } \\
1977\end{array}$ \\
\hline Jamaica & 3.10 & & $\begin{array}{c}\text { Parekh \& Goldberger, } \\
1976 \text { Picnometro }\end{array}$ \\
\hline Suriname & 2.67 & & $\begin{array}{l}\text { Parekh \& Goldberger, } \\
1976\end{array}$ \\
\hline $\begin{array}{c}\text { Arkansas - Estados } \\
\text { Unidos }\end{array}$ & 2.65 & & $\begin{array}{c}\text { Parekh \& Goldberger, } \\
1976\end{array}$ \\
\hline Boké - Sudáfrica & 2.89 & & $\begin{array}{l}\text { Parekh \& Goldberger, } \\
1976\end{array}$ \\
\hline
\end{tabular}




\subsubsection{Limites de Atterberg}

O material utilizado nesta pesquisa é aquele descartado antes da aplicação do processo Bayer, não se encontrou na literatura informações específicas. Villar et al. (2009) apresenta resultados de ensaios de caracterização em rejeitos lavados (B), de Porto Trombetas (PT) e daqueles submetidos ao processo Bayer (LV), procedentes de Poços de Caldas (PC e Ouro Preto (OP). Os autores obtiveram resultados que indicam uma redução na plasticidade do material após o processo Bayer, conforme ilustra a Figura 4-20. No entanto, deve-se observar que embora a lama vermelha (após processo Bayer) seja mais fina granulometricamente do que o rejeito lavado o processo químico a que a lama é submetida reduz a plasticidade do material.

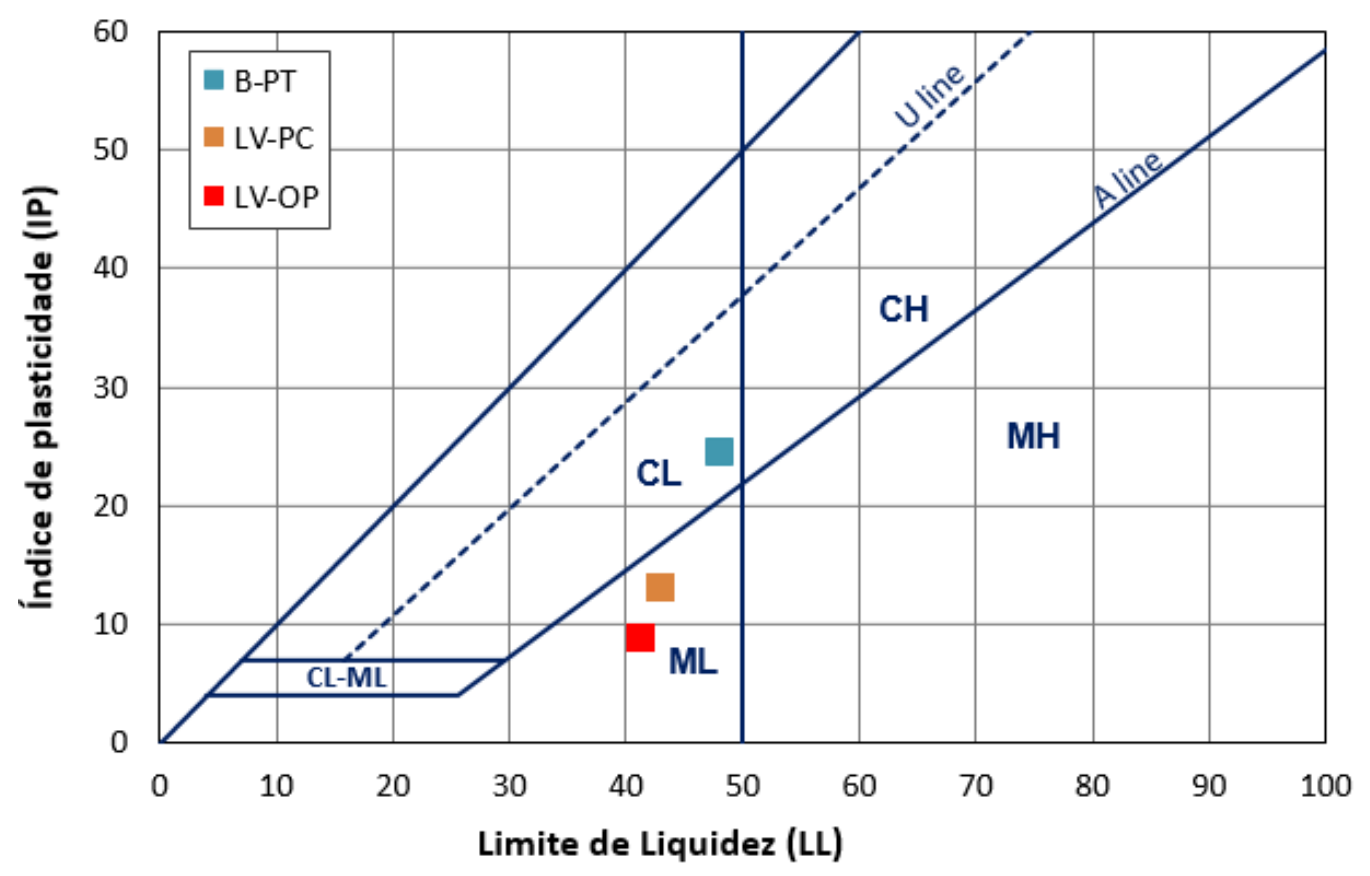

Figura 4-20 - Classificação na carta de Casagrande de rejeito de bauxita lavada e rejeitos de bauxita após processo Bayer (red muds)

Tabela 4-7 Resultados de Limites de Atterberg para lama vermelha.

\begin{tabular}{ccccc}
\hline Localização & LL (\%) & IP (\%) & Classificação & Referência \\
\hline Odisha-India & 41 & 5 & ML & Reddy e Rao, 2016 \\
\hline Jamaica & 44 & 11 & - & Gore, 2015 \\
\hline Singaredi- Guiné & 44 & 11.0 & - & Gore, 2015 \\
Renukoot - India & 45.5 & 13.2 & ML & Deelval et al, 2014 \\
Odisha-India & 24.75 & 7.25 & ML -CL & Rout et al, 2013 \\
Pará Brasil & 57.4 & 25.5 & - & Pedrosa, 2012 \\
\hline
\end{tabular}




\subsubsection{Compactação}

Reddy e Rao (2016), avaliaram as características de compactação em amostras de lama vermelha: Tratada com soluções de $\mathrm{NaCl}$ (cloreto de sódio) e $\mathrm{HCl}$ (ácido clorídrico) e não tratada (amostras provenientes da Mineração NALCO, em Odisha, Índia). O estudo surge com a preocupação devido à escassez de recursos naturais utilizados como matérias de construção seja de aterros ou rodovias, perante o aumento de resíduos provenientes da mineração e de como aplicar estes como material alternativo no desenvolvimento sustentável da infraestrutura.

A Figura 4-21 apresenta os resultados de umidade ótima com sua respectiva densidades seca máxima, observa-se que os resultados para as amostras não tratadas para o ensaio Proctor normal mostram que a densidade seca tem valores que variam entre $12 \mathrm{kN} / \mathrm{m}^{3}$ a $16 \mathrm{kN} / \mathrm{m}^{3}$ e umidade ótima variando desde $33 \%$ até $45 \%$ de umidade, uma explicação para isto é a soda cáustica $(\mathrm{NaOH})$ presente nas amostras de lama vermelha, a qual pode aumentar o efeito de deslizamento entre partículas que influi no efeito de lubrificação influenciando nas características de compactação. No caso do ensaio Proctor modificado observasse que os resultados para as três amostras ficaram muito próximos.

Uma das preocupações que se tem com a lama vermelha é a neutralização da soda cáustica presente nela, assim foram realizados ensaios de compactação Proctor normal e modificado em amostras de lama vermelha misturadas com soluções de $\mathrm{NaCl}$ e $\mathrm{HCl}$, com o objetivo de observar o comportamento das características de compactação lama vermelha 


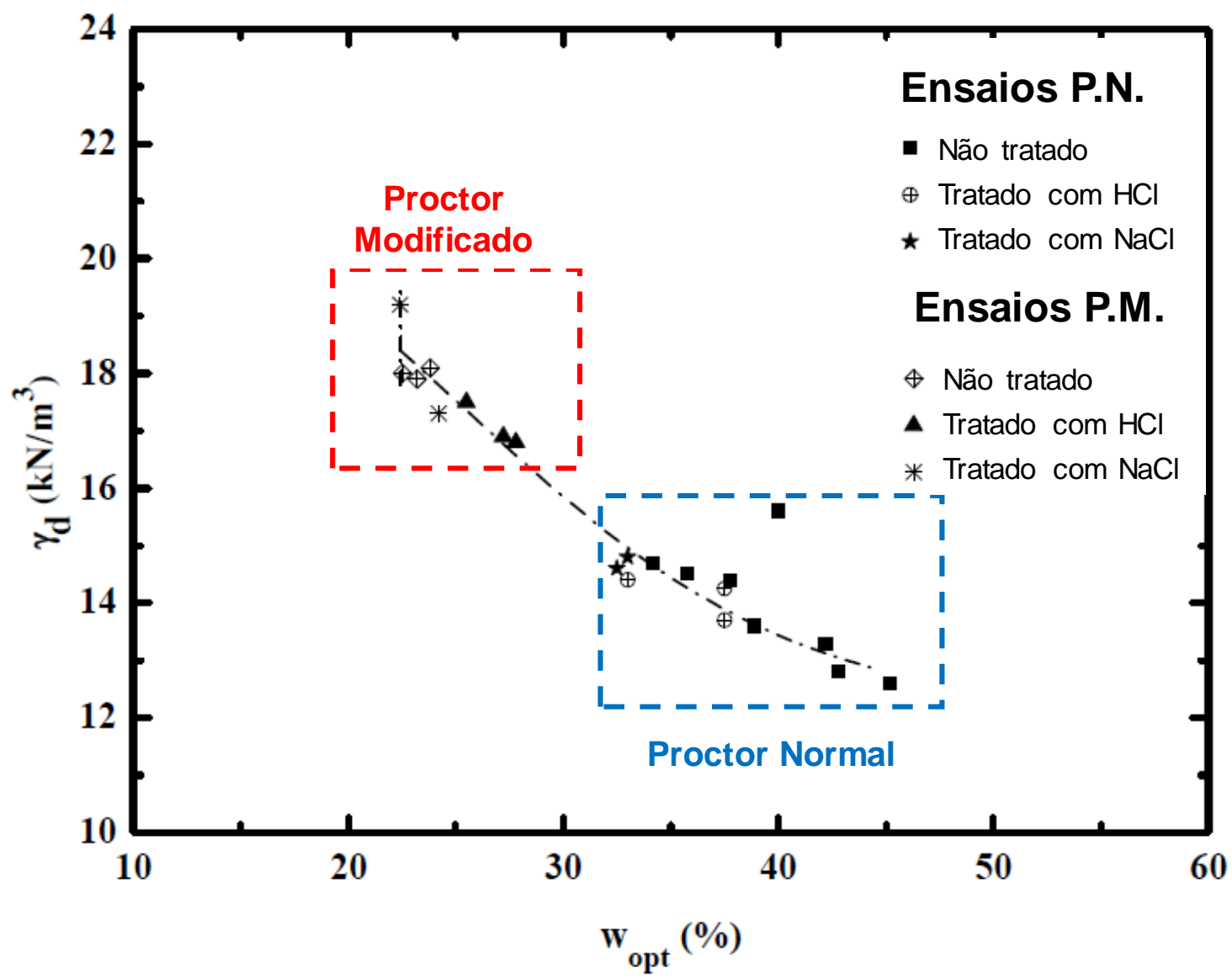

Figura 4-21 - Resultados de umidade ótima $x$ peso seco máximo a partir dos ensaios Proctor normal e Proctor modificado realizados em amostras de lama vermelha da Índia (Reddy e Rao, 2016)

As amostras de lama vermelha tratadas com cloreto de sódio $(\mathrm{NaCl})$ apresentam peso seco maior, porém umidade ótima inferior comparado com as amostras não tratadas, isto pode estar ligado à substituição da água por sais, levando a uma diminuição da umidade e aumentando o efeito de lubrificação entre partículas deixando a estrutura da amostra mais compacta. Já as amostras de lama vermelha tratadas com ácido clorídrico $(\mathrm{HCl})$ que ao entrar em contato com a soda cáustica libera água que resulta no aumento da umidade ótima das amostras. Pode-se concluir que as características de compactação se mostraram mais satisfatórias no caso das amostras tratadas com cloreto de sódio $(\mathrm{NaCl})$ em ambos os ensaios Proctor normal e modificado.

Gore et al (2016), com o objetivo de utilizar resíduos de lama vermelha na construção de diques, estudaram dois tipos de lama vermelha provenientes de refinarias distintas localizadas nos Estados Unidos, as quais denominaram R1 e R2. Porém os minérios de bauxita que geraram estes resíduos na refinaria são provenientes da Jamaica, no caso do R1 e de Guiné, no caso do R2. O minério 
da Jamaica provém de reservas de bauxita cárstica. Já o minério de Guiné tem sua origem em reservas de bauxita laterítica.

A amostra R1 foi coletada no centro da lagoa do dique de contenção de lama vermelha com $120 \%$ de teor de umidade. Para o resíduo 02 foram coletadas três amostras vindas de locais diferentes, a forma de armazenamento nesta refinaria é pelo método do empilhamento a seco "Dry-Stacking" e este resíduo contém entre $60-70 \%$ de teor de umidade

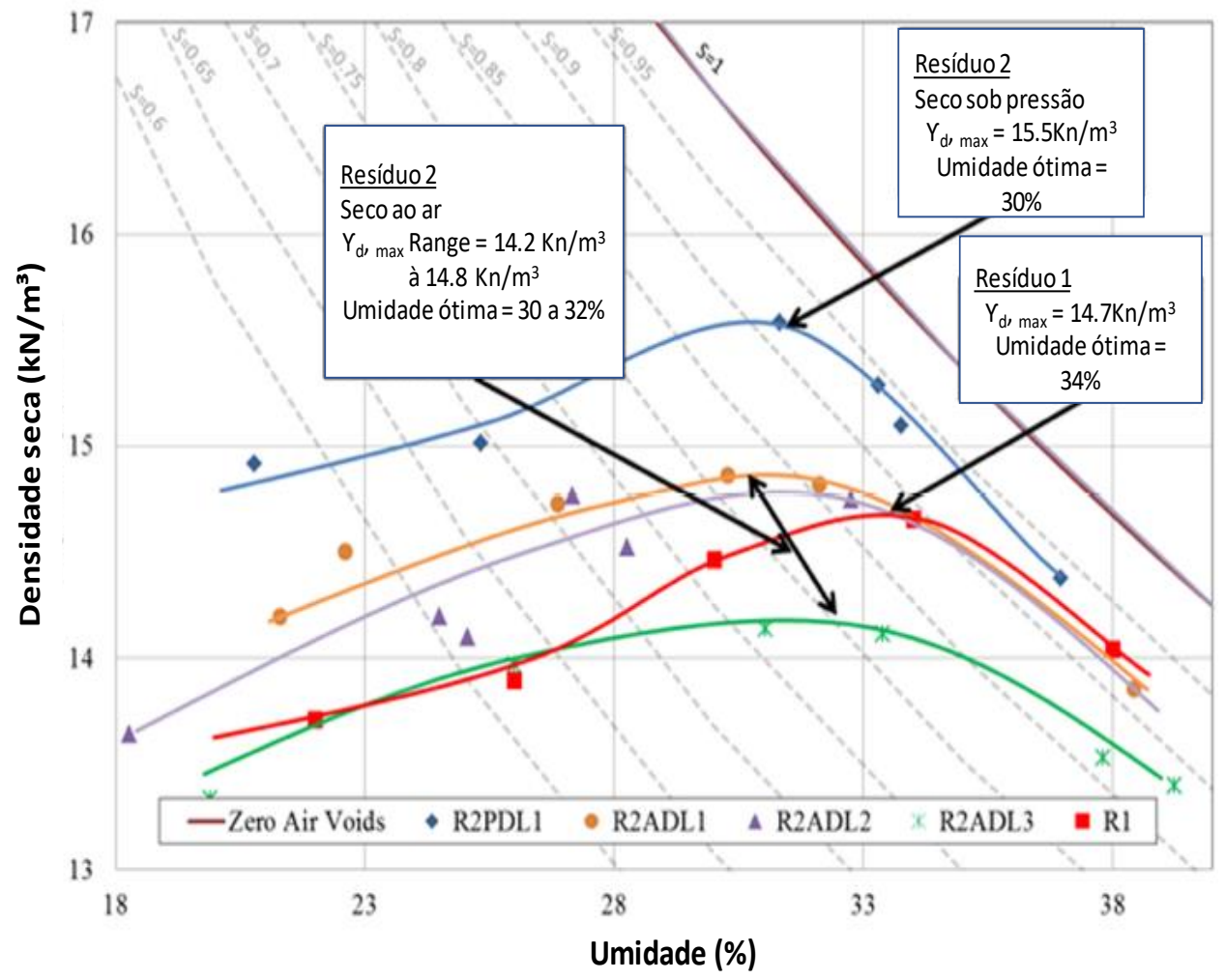

Figura 4-22 - Resultados de umidade ótima $x$ peso seco máximo a partir dos ensaios Proctor normal e lama vermelha proveniente da Guinea (Gore et al, 2016)

\subsubsection{Condutividade Hidráulica}

Tabela 4-8 Valores de condutividade hidráulica para rejeitos de bauxita.

\begin{tabular}{cccc}
\hline Localização & $\mathrm{k}$ & Referência & Método \\
\hline Guinea & $(1.2-6.3) \times 10^{-7}$ & $\begin{array}{c}\text { Gore, } \\
2015\end{array}$ & Parede rígida - Câmara Triaxial \\
Guinea & $(1.4-1.5) \times 10^{-6}$ & $\begin{array}{l}\text { Gore, } \\
2015\end{array}$ & Paréde Fléxivel Falling head test \\
Odisha-India & $(1.16-5.8) \times 10^{-7}$ & $\begin{array}{l}\text { Rout et } \\
\text { al,2013 }\end{array}$ & Não explica o método
\end{tabular}




\subsubsection{Compressibilidade}

Tabela 4-9 Resultados de parâmetros de compressibilidade de lama vermelha.

\begin{tabular}{|c|c|c|c|c|}
\hline Pais & Métodos & $\mathrm{C}_{\mathrm{c}}$ & $\mathrm{C}_{\mathrm{v}}$ & Referência \\
\hline Jamaica & $\begin{array}{l}\text { Oedométrico } \\
\text { Convencional }\end{array}$ & 0.56 & - & Gore,2015 \\
\hline Guiné & $\begin{array}{l}\text { Oedométrico } \\
\text { Convencional }\end{array}$ & 0.36 & - & Gore,2015 \\
\hline $\begin{array}{l}\text { Maranhão } \\
\text { - Brasil }\end{array}$ & Oedômetro & - & $(1-2) \times 10^{-3}$ & Bedin, 2006 \\
\hline $\begin{array}{l}\text { Maranhão } \\
\text { - Brasil }\end{array}$ & Oedômetro & - & $7 \times 10^{-3}-2.1 \times 10^{-2}$ & Bedin,2006 \\
\hline $\begin{array}{l}\text { Maranhão } \\
\text { - Brasil }\end{array}$ & $\begin{array}{l}\text { Adensamento } \\
\text { Convencional }\end{array}$ & - & $7 \times 10^{-3}-8 \times 10^{-3}$ & Bedin, 2006 \\
\hline $\begin{array}{l}\text { Estados } \\
\text { Unidos }\end{array}$ & $\begin{array}{l}\text { Oedométrico } \\
\text { Convencional }\end{array}$ & - & $1.6 \times 10^{-3}-9.5 \times 10^{-3}$ & Elias, 1995 \\
\hline Brasil & $\begin{array}{c}\text { Tensão } \\
\text { Controlada }\end{array}$ & - & $1.6 \times 10^{-3}-9.5 \times 10^{-7}$ & Stinson,1981 \\
\hline Australia & $\begin{array}{c}\text { Tensão } \\
\text { Controlada }\end{array}$ & - & $1.6 \times 10^{-3}-9.5 \times 10^{-6}$ & Stinson, 1981 \\
\hline África & $\begin{array}{c}\text { Tensão } \\
\text { Controlada }\end{array}$ & - & $1.6 \times 10^{-3}-9.5 \times 10^{-5}$ & Stinson, 1981 \\
\hline Jamaica & $\begin{array}{c}\text { Tensão } \\
\text { Controlada }\end{array}$ & - & $1.6 \times 10^{-3}-9.5 \times 10^{-4}$ & Stinson, 1981 \\
\hline $\begin{array}{l}\text { Estados } \\
\text { Unidos }\end{array}$ & $\begin{array}{l}\text { Oedométrico } \\
\text { Convencional }\end{array}$ & - & $10^{-3}-10^{-2}$ & $\begin{array}{c}\text { Somogyi \& Gray } \\
, 1977\end{array}$ \\
\hline
\end{tabular}

\subsubsection{Resistencia ao cisalhamento}

Tabela 4-10 Resultados de parâmetros de resistência de lama vermelha.

\begin{tabular}{ccccc}
\hline Pais & $\varphi^{\prime}$ & $c^{\prime}$ & Referência & Observações \\
\hline Jamaica & 39.4 & 9.65 & Gore, 2015 & Ensaio CU \\
\hline $\begin{array}{c}\text { Guinea } \\
\text { Renukoot }\end{array}$ & 33.5 & 11.72 & Gore, 2015 & Ensaio CU \\
- India & 26.8 & 12.3 & Deelval et al, 2014 & Confinantes 50,100,150 \\
$\begin{array}{c}\text { Odisha- } \\
\text { India }\end{array}$ & 34.38 & 28.8 & Rout et al, 2013 & \\
$\begin{array}{c}\text { Estados } \\
\text { Unidos }\end{array}$ & 22 & 100 & Somogyi \& Gray, 1977 & Ensaio ClU
\end{tabular}




\begin{tabular}{lcccc} 
Estados & 42 & 0 & Somogyi \& Gray , & Ensaio CID \\
Unidos & 42 & 1977 & \\
\hline
\end{tabular}

\subsubsection{Potencial de Liquefação}

As pesquisas relacionadas ao fenômeno de liquefação têm crescido nas últimas décadas devido principalmente a diversos registros de rupturas associadas a este fenômeno. As rupturas nem sempre se relacionam diretamente com rejeitos, mas nos dá uma ideia da abrangência do problema. As rupturas por liquefação incluem os seguintes casos:

- Barragens de rejeitos.

- Encostas.

- Solo (inclinação prédios, silos, casas).

- Naufrágio de navios de transporte de minério.

A liquefação é o fenômeno de perda súbita de resistência ao cisalhamento, devido ao acréscimo de pressão da água, sob condições não drenadas. $O$ fenômeno de liquefação está ligado ao comportamento de solos não coesivos ou granulares os quais ao serem solicitados por esforços de cisalhamento tendem a se contrair. A contração é impedida pela velocidade de carregamento associada a dificuldade que a água tem de dissipar a pressão da água dos poros induzida.

A liquefação é dividida em liquefação dinâmica e estática. A liquefação dinâmica está relacionada com carregamentos dinâmicos fruto de esforços sísmicos ou vibrações causadas por explosões. A liquefação estática, depende de carregamentos sucessivos rápidos como a variação do nível de água de forma cíclica ou rápida, elevação do nível de água, ou carregamentos adicionais, entre outros. O fenômeno é induzido pela redução da tensão efetiva. Ou seja, qualquer evento que gere um aumento da pressão da água de forma rápida pode induzir a liquefação estatíca. (e.g. Jabur et al, 2006; Davies et al, 2002).

Os fatores que influenciam o fenômeno de liquefação estão associados a natureza do material (distribuição granulométrica, composição mineralógica,), ao seu estado (compacidade relativa, condutividade hidráulica) e a fenômenos externos (chuvas, velocidade de carregamento). 
Materiais de granulometria uniforme e fina, principalmente areia fina (granulometria típica de um material de rejeitos) são mais susceptíveis à liquefação (Poulos et al. 1985). Terzaghi et al. (1996) reproduz resultados de Tsuchida (1970) e Ishihara (1985) que estabelece uma faixa granulométrica dos solos com potencial de liquefação (Figura 4-23). O estudo baseou-se em ensaios de laboratório onde os solos eram submetidos a processo que poderiam induzir liquefação. Embora Tsuchida (1970) tenha-se estabelecido, os resultados de Ishihara(1985) indicam que no caso de rejeitos de mineração é possível se ter materiais finos granulometricamente (silte e argilas) sujeitos a liquefação devido a estes não serem materiais plásticos.

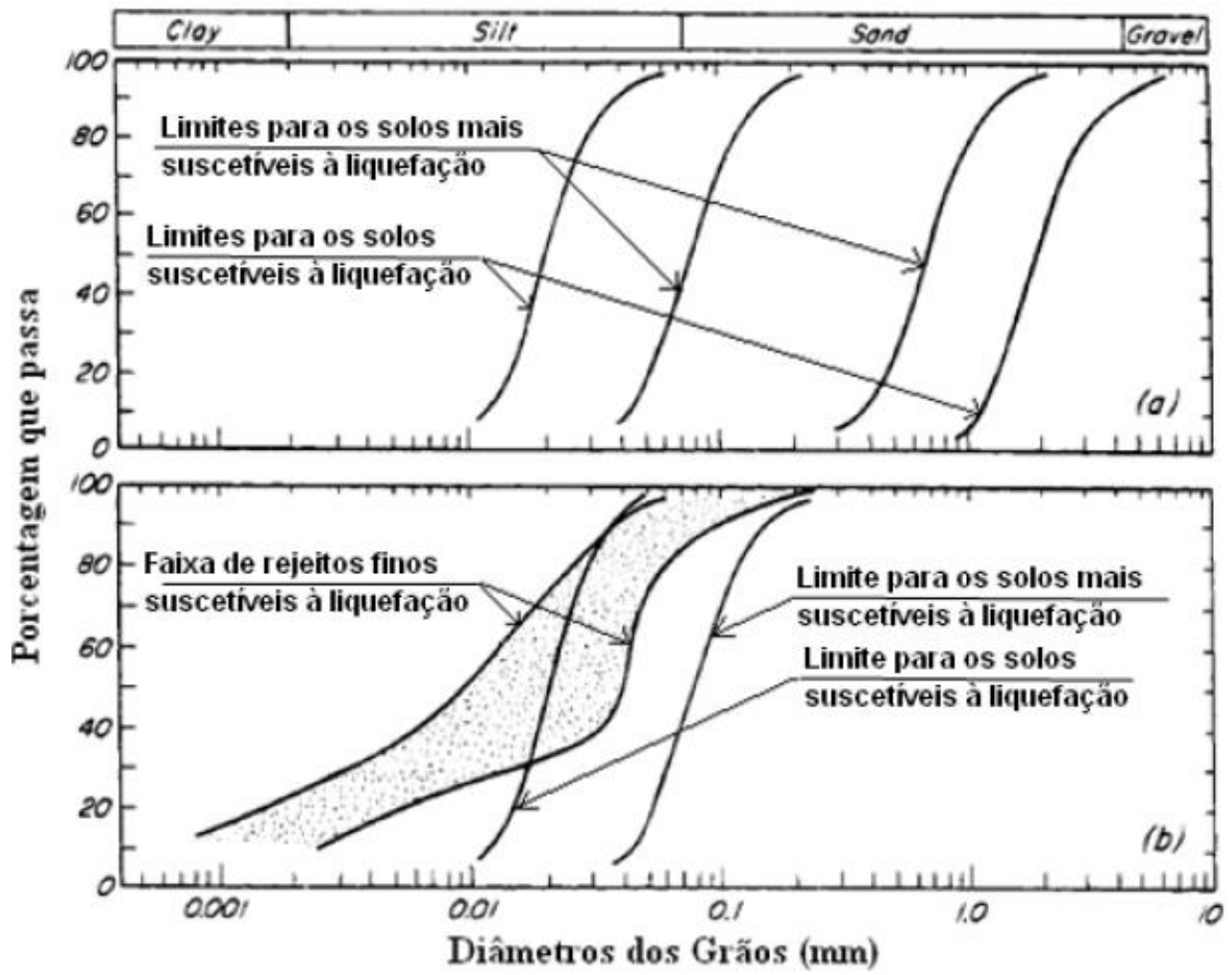

Figura 4-23 - (a) Faixas granulométricas de solos suscetíveis a liquefação e não suscetíveis (b) Faixas granulométricas para rejeitos de mineração com baixa resistência a liquefação. (Fonte: Modificado de Terzaghi et al, 1996.

\subsubsection{Determinação do índice de vazios crítico}

A tendência de um material particulado variar de volume durante um processo de ruptura irá induzir a geração de pressão de água positiva ou negativa se a drenagem não for possível. Como no caso de solos plásticos, menos permeáveis, os materiais não plásticos, mais permeáveis, podem apresentar uma condição não drenada em função da velocidade de carregamento e de seu índice de vazios. A previsão do comportamento de materiais não coesivos não é 
simples pois depende da combinação entre o estado de tensão e o índice de vazios do material.

$\mathrm{Na}$ literatura encontram-se muitos estudos sobre os processos de liquefação de solos (e.g. Seed \& Idriss, 1971; Iwasaki, 1986; Yamamuro \& Lade, 1997, dentre outros. No caso de materiais granulares a relatividade do índice de vazios é representada pela densidade relativa (Dr). Materiais granulares que apresentam baixos índices de vazios iniciais, ou seja, elevadas densidades relativas, apresentam chances reduzidas de rupturas por liquefação. Para melhor caracterizar a suscetibilidade do material à liquefação é importante definir o índice de vazios crítico.

Na Figura 4-24 observa-se que a partir de ensaios triaxiais realizados em areias na condição densa ( e $_{4}$ e e e $)$ e fofa (e e e e 1 ), pode-se determinar o índice de vazios crítico situação em que o solo sofre deformação sem variação de volume. A condição da areia fofa é a mais susceptível a liquefação. Quando uma areia está com um índice de vazios superior ao índice de vazios crítico, ao ser carregada ela vai se comprimir tendendo a expulsar a água, em carregamentos sucessivos por falta de tempo suficiente, a água irá ficar com pressões positivas muito altas fazendo com que a tensão efetiva se reduza drasticamente levando a uma queda súbita da resistência, este fenômeno faz com que a areia se liquefaça.

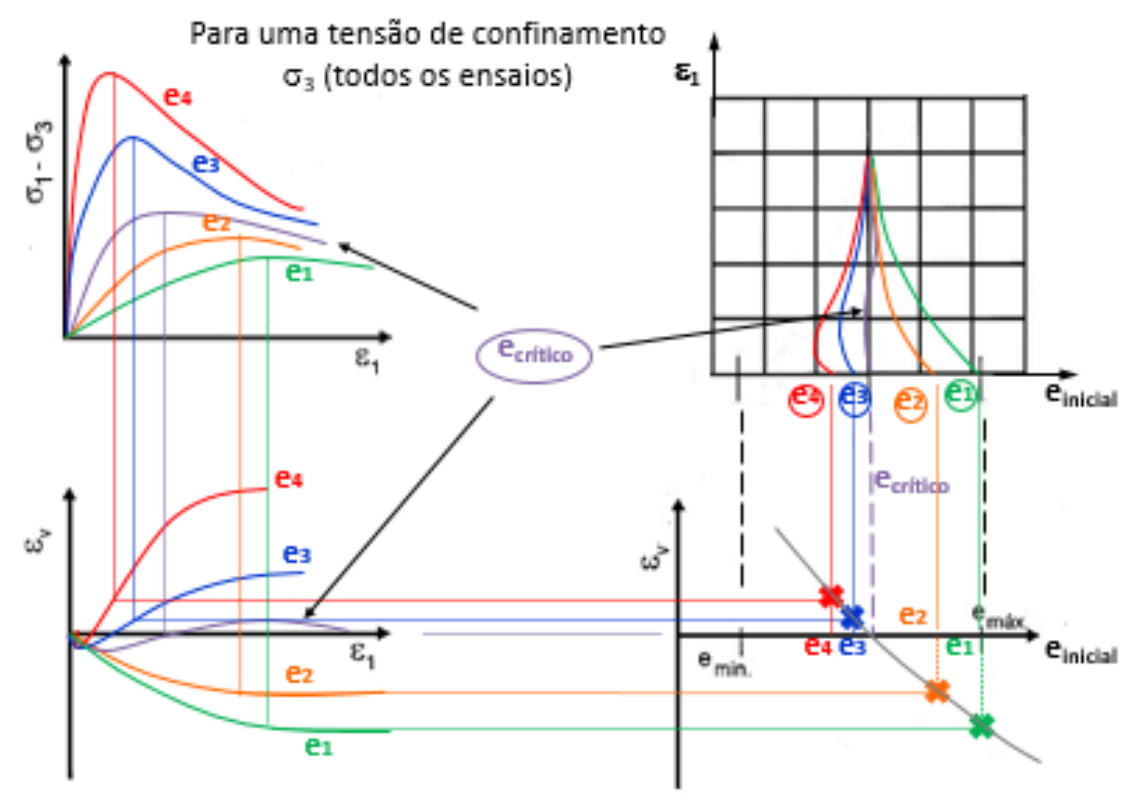

Figura 4-24 - Determinação do Índice de vazios critico (PINTO, 2006).

Davies et al. (2002) apresentam esquematicamente o resultado de um ensaio em um material fofo e saturado submetido a carregamentos triaxiais não 
drenados, monotônico e cíclico. Na Figura 4.13 estão apresentados resultados esquemáticos em termos de curva tensão deformação e também a trajetória de tensões. Nesta está indicado o conceito de superfície de colapso, introduzida por Sladen et. al. (1985) e que deverá ser analisada no presente estudo. Diferentes formas de carregamento, cargas monotônicas aplicadas de forma rápida (sem drenegam) ou carregamentos cíclicos podem levar o material a encontrar a superfície de colapso, conforme indicado na Figura 4.13. quando o estado de tensão é tal que encontra a superfície de colapso observa-se uma perda drástica de resistência. Conforme mencionado por Davies et al. (2002) o conceito de superfície de colapso é um conceito que permite vincular trajetórias estáticas e sísmicas que induzem a liquefação.
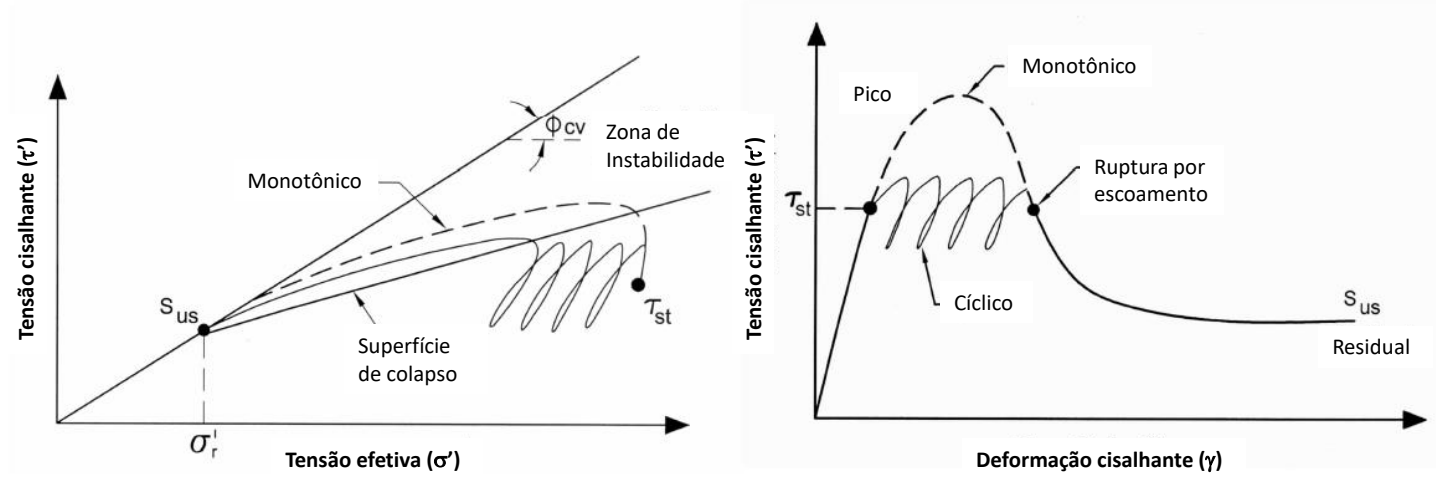

Figura 4.13 - Resposta esquemática de um material não coesivo, saturado e fofo sob carregamento monotónico e cíclico. 


\section{MATERIAL ESTUDADO}

Neste capítulo, se apresenta a proveniência do material de estudo, o local da sua coleta e as operações envolvidas na sua geração.

5.1 Rejeitos de bauxita lavada - Votorantim Metais - Unidade Miraí

O material em estudo é um rejeito proveniente do processo de beneficiamento de bauxita laterítica, lavrada no município de Miraí - Zona da Mata no estado de Minas Gerais, Brasil. A planta de beneficiamento vista na Figura 5-1 e área de mineração pertencem à mineradora Votorantim Metais, em operação desde 2008.

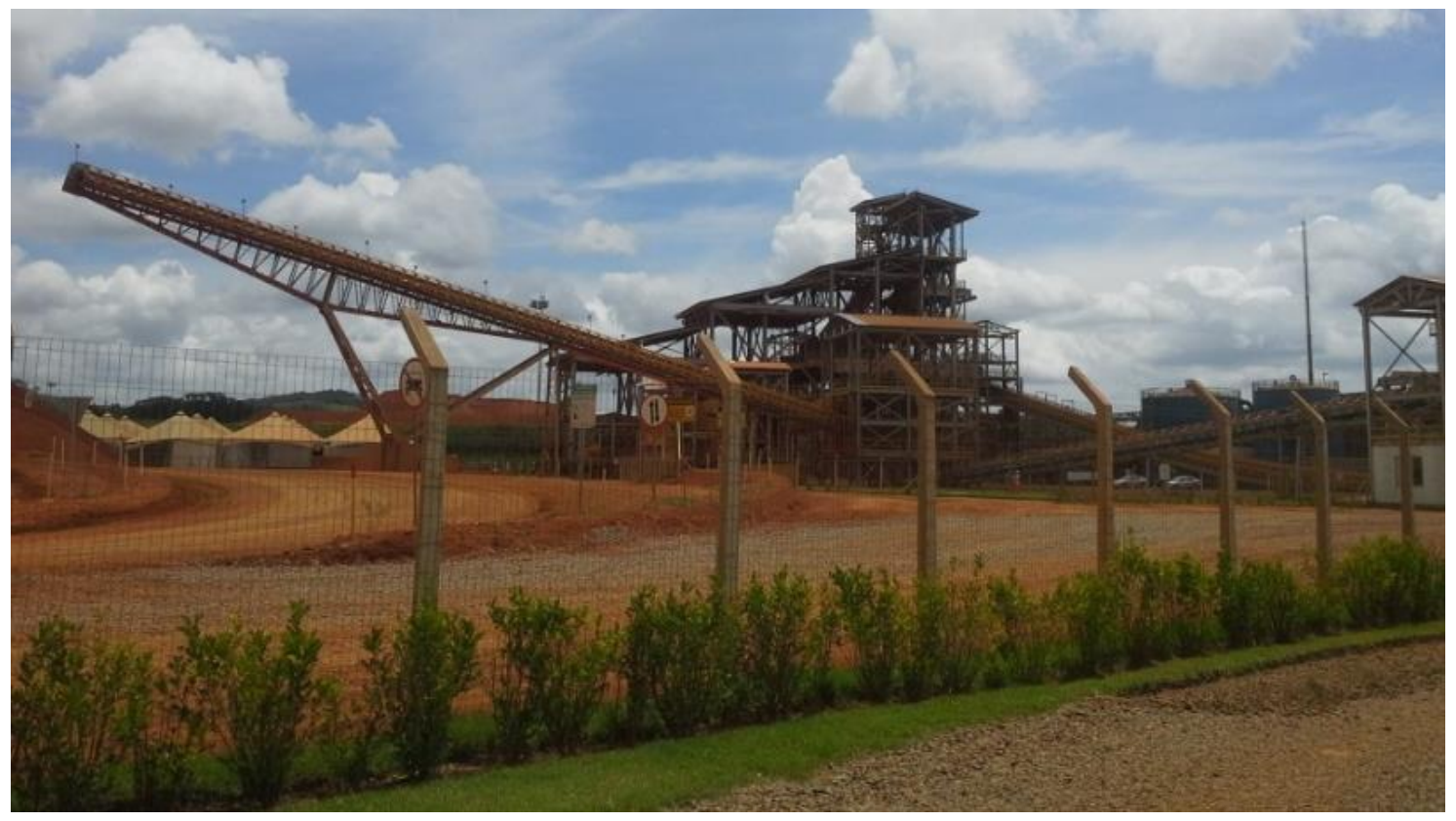

Figura 5-1 - Usina de beneficiamento de minério de bauxita - Unidade Miraí. (Autor,2016)

Para a obtenção do alumínio primário estão envolvidos três grandes estágios, sendo estes:

- A mineração de bauxita;

- O processo Bayer para a obtenção da alumina e;

- O processo eletrolítico Hall-Herault para obtenção do alumínio primário.

Neste capítulo se dá ênfase aos processos envolvidos na usina de beneficiamento aonde são obtidos dois produtos:

- O minério bauxita beneficiado também conhecido como bauxita lavada (Andrade et al, 2012) e; 
- O rejeito de bauxita lavada (objeto do nosso estudo), polpa que é lançada para seu armazenamento, por via hidráulica e por gravidade, para a barragem, aonde é deixado sedimentar naturalmente. A água superficial é bombeada e retorna ao processo de beneficiamento.

Os minérios de bauxita brasileira apresentam nas suas frações finas um alto grau de sílica reativa que está presente no argilomineral caulinita que é um sílicato de alumínio hidratado (Andrade et al,2012; Rachel et al, 2012; Van Deursen 2016)

Os custos operacionais numa refinaria de alumina (material obtido através do processo Bayern) podem ficar mais encarecidos se o minério de bauxita a ser refinado apresentar um elevado teor de sílica reativa; já que quando a sílica reativa se solubiliza na presença de hidróxido de sódio $(\mathrm{NaOH})$ conhecido como soda cáustica, ocorre a precipitação da sodalita Bayer levando a uma perda de sódio que deverá ser restituída com acréscimos de soda cáustica.

Rachel et al (2012), afirmam que: "A soda cáustica pode ser responsável por até $15 \%$ das despesas operacionais (OPEX - operational expenditures) em uma refinaria de alumina. As despesas operacionais (OPEX) são os custos recorrentes para o funcionamento de uma mina, incluem custos diretos e indiretos para minar, processar e vender o minério".

Para Van Deursen (2016): "O custo do processo de refino de alumina é influenciado pela quantidade necessária de reposição de $\mathrm{NaOH}$ por tonelada de alumina produzida"

Pelo exposto, com a finalidade de evitar maiores custos, grande parte das mineradoras brasileiras tem incluído plantas de beneficiamento, antes de encaminhar o minério para o processo Bayer, com o objetivo de separar as frações finas que contêm os altos teores de sílica reativa. Nas plantas de beneficiamento, o teor de caulinita é reduzido por meio de processos mecânicos que separam as frações finas (que contêm os argilominerais) das frações grossas.

Por tanto, a separação da sílica reativa associada à caulinita que faz parte do minério de bauxita vem a ser a principal justificativa de que, no Brasil, no processo de obtenção de alumina, sejam gerados dois tipos de resíduos sendo: 
- Um rejeito proveniente da mineração de bauxita ou rejeito de bauxita lavada;

- Um resíduo gerado na obtenção da alumina no processo Bayer, conhecida mundialmente como lama vermelha "red-mud".

\subsection{Operações na planta de beneficiamento}

O rejeito estudado vem de uma planta de beneficiamento do minério bauxita. Nesta planta são executados processos mecânicos sequenciais, sem nenhuma adição de substancias químicas. Estes processos são: Cominuição (britagem), lavagem (desagregação) e separação (peneiramento).

Os produtos obtidos na planta são: o rejeito, que é uma polpa composta de frações finas com granulometria abaixo de $0,6 \mathrm{~mm}$, a qual passará a ser armazenada na barragem, e o minério bauxita beneficiado com frações grossas acima de $0,6 \mathrm{~mm}$, que continua para a refinaria para a obtenção da alumina.

O fluxograma do processo de obtenção de alumínio está apresentado na Figura $5-2$. 


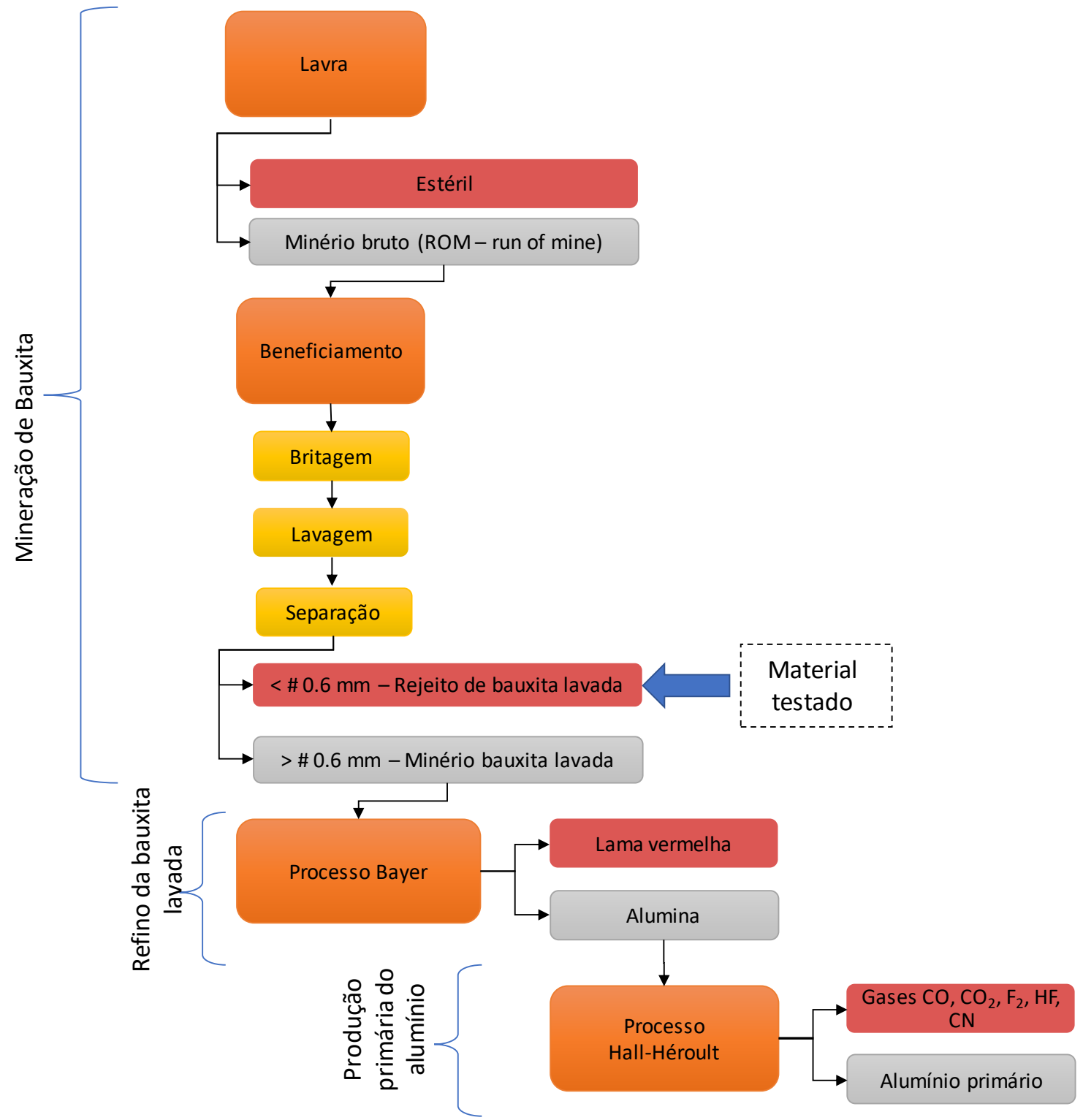

Figura 5-2- Fluxograma para obtenção do alumínio.

\subsubsection{Cominuição;}

Também conhecida como fragmentação, a cominuição é um conjunto de operações mecânicas cujo objetivo é de reduzir as dimensões do material lavrado, seja um conjunto de blocos de rocha por exemplo. O desmonte de rochas por explosivo pode ser considerado como um primeiro estágio de cominuição (Galery et al, 2012).

De acordo com Galery et al (2012) os principais objetivos da cominuição são:

- Conseguir a concentração de minério que tem interesse econômico

- Fragmentar o minério bruto de forma que atinja as dimensões granulométricas necessárias requeridas no mercado. 
Na planta de beneficiamento Miraí, o processo de cominuição se inicia com o carregamento da moega que é um dispositivo de armazenamento e passagem de ROM - Run of mine (termo usado para denominar o minério bruto vindo direto da mina) o qual passara por uma britagem primária e secundária.

A alimentação da moega é realizada por meio de pás carregadeiras, que carregam o material estocado em forma de pilhas num pátio denominado "pulmão" como pode ser observado na Figura 5-3.

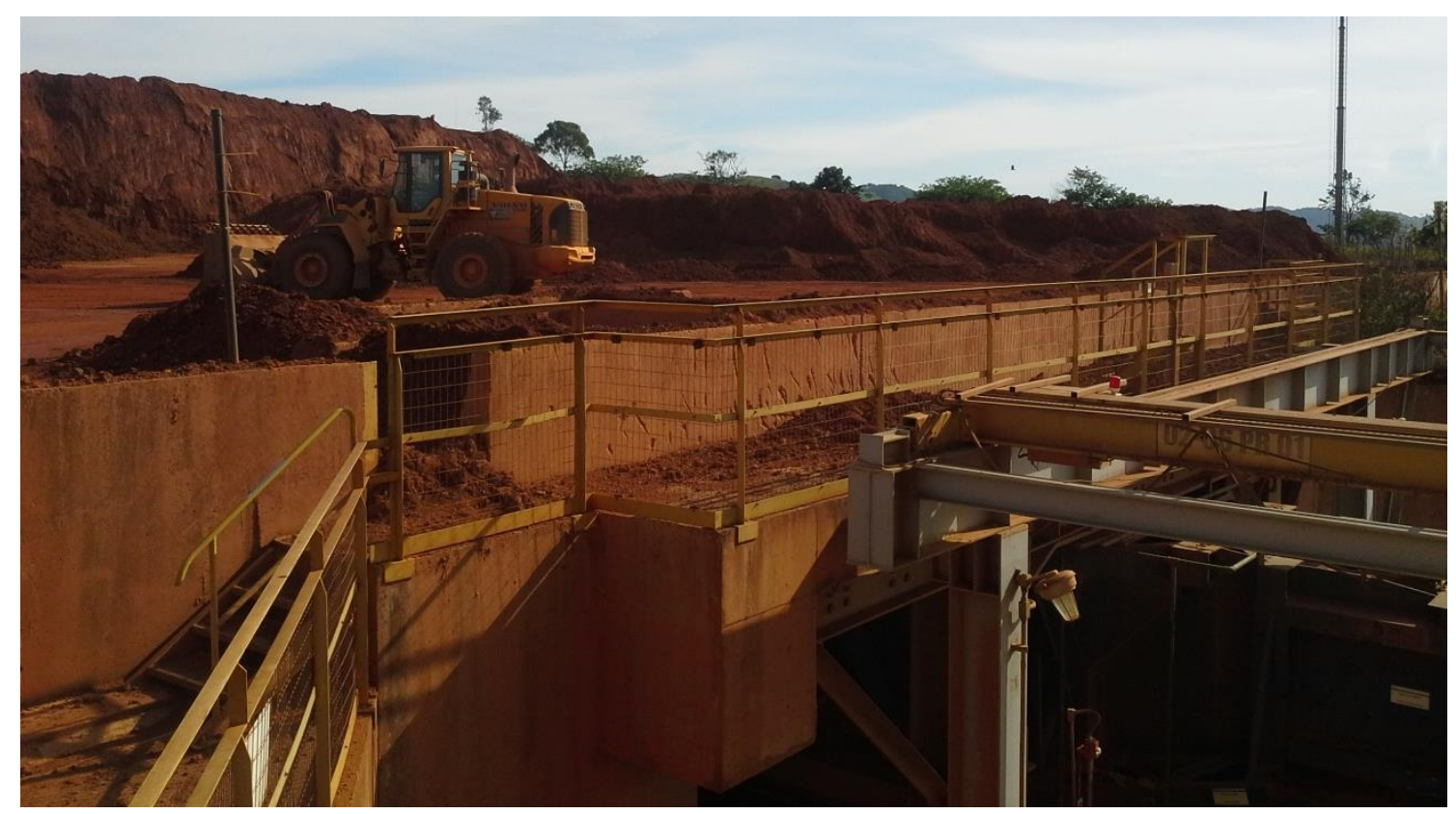

Figura 5-3 - Alimentação da moega com pá carregadeira - Unidade Miraí (Acervo pessoal, fev./2016).

A moega possui um alimentador que leva o minério para um britador primário do tipo Sizer. O britador tipo sizer é um sistema de esmagamento com rolos que possui dois eixos localizados numa câmara de britagem. O minério é esmagado por forças de cisalhamento e tração geradas por torques com baixa velocidade. Este sistema é recomendado para minerais úmidos e pegajosos, aonde os finos passam através dos rolos sem serem esmagados.

A britagem primária reduz o ROM a uma granulometria inferior a 6" (15.2mm). O minério continua para a britagem secundária através de correias, passando previamente por um extrator de sucatas que possui um detector de metais, assim metais leves ou sujeiras existentes no minério são extraídos, isto evita possíveis problemas nos equipamentos os quais poderiam paralisar a produção. A Figura 5-4 mostra o minério limpo seguindo para o britador sizer secundário, nesta fase o minério é reduzido a uma granulometria inferior a 2" $(5.1 \mathrm{~mm})$. 


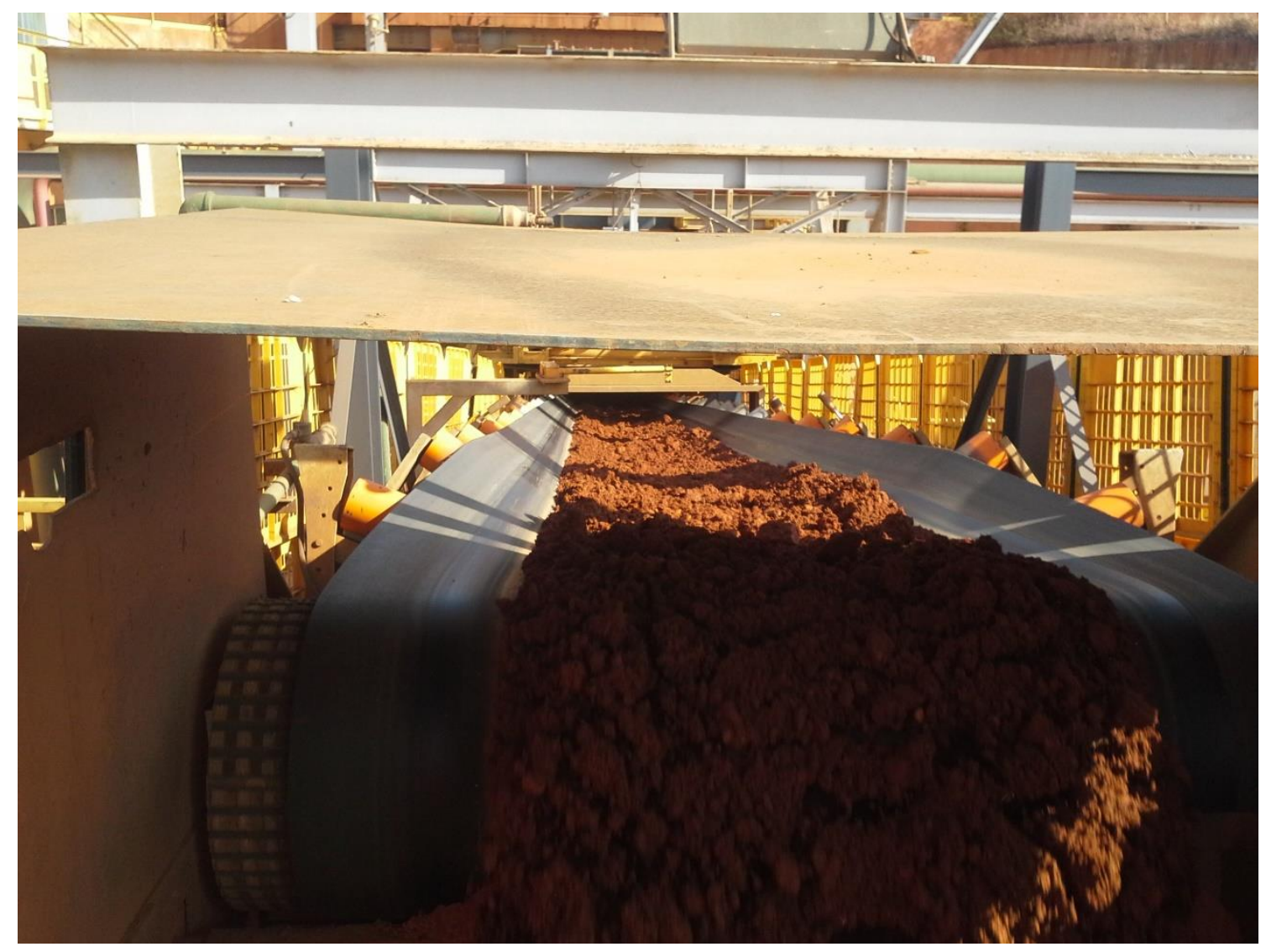

Figura 5-4 - Correia transportadora levando o minério bruto passando pelo extrator de sucatas - Unidade Miraí (Acervo pessoal, fev./2016).

A Figura 5-5 mostra o britador sizer em funcionamento esmagando o minério.

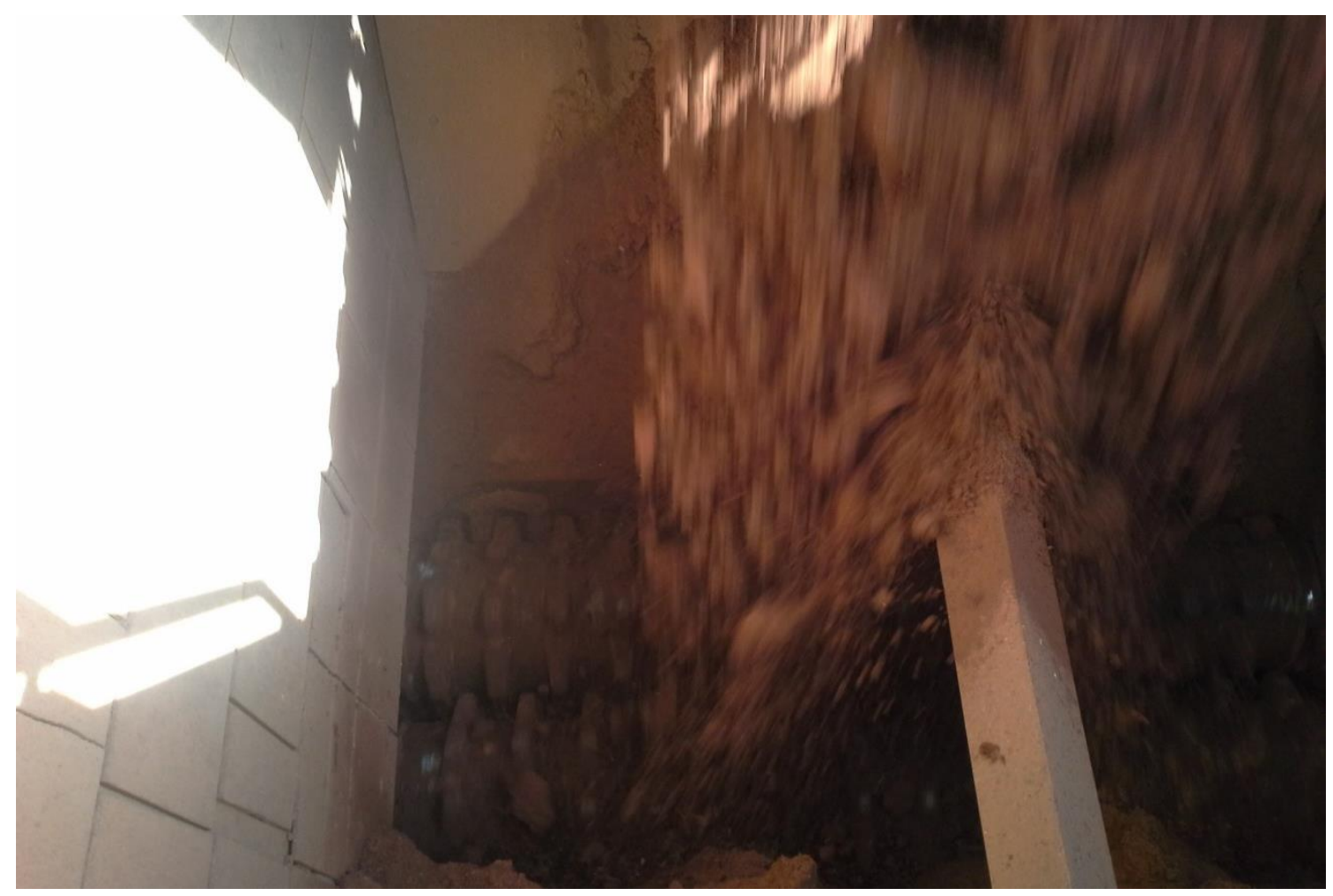

Figura 5-5 - Britador do tipo sizer esmagando o minério bruto de bauxita - Unidade Miraí (Acervo pessoal, fev./2016). 
Finalizado o processo de cominuição o minério britado continua para o processo de lavagem.

\subsubsection{Lavagem}

A primeira adição de água no processo acontece no interior de um equipamento denominado Scrubber, que é um tambor de desagregação e lavagem comumente utilizado em usinas de beneficiamento de bauxita no Brasil (Alves\&Reis, 2008). A quantidade de água que entra no circuito está relacionada com a taxa de alimentação da usina e a qualidade do minério bruto.

Continuando com o processo de beneficiamento o minério britado vindo através de correias transportadoras é armazenado num silo antes de ir para o Scrubber; este equipamento cilíndrico possui uma entrada e uma saída nas extremidades, com uma leve inclinação em relação à horizontal e que gira em torno do seu próprio eixo. A Figura 5-6 mostra o Scrubber da usina.

No Scrubber, o minério mais a adição de água, originam um material heterogêneo denominado: polpa. Com a lavagem e desagregação pretende-se separar as frações mais finas que contém as argilas, as quais encontram-se aglomeradas ou aderidas às frações mais grosas (no caso a gibbsita).

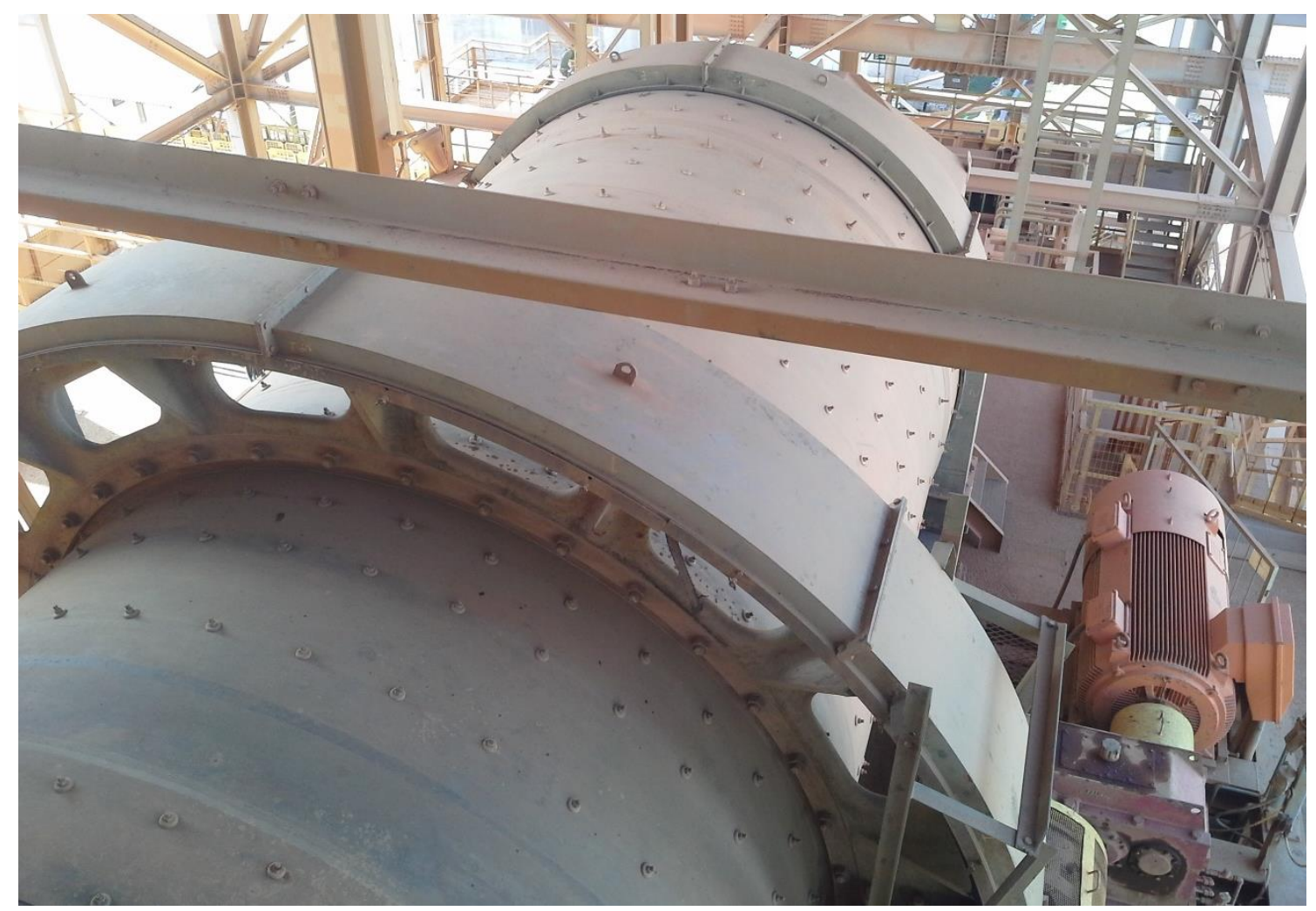

Figura 5-6 - Lavagem no tambor desagregador denominado Scrubber - Unidade Miraí (Acervo pessoal, fev./2016). 
Costa \& Delboni (2012) consideram as partículas finas uma fração indesejável, que diminuem o valor agregado do minério, muitas vezes aderidas às partículas grossas. Estas partículas finas presentes também na forma de aglomerados, deverão ser quebrados, dissolvidos e separados das frações grossas de valor econômico.

\subsubsection{Separação}

O processo de beneficiamento finaliza com a operação de separação. A polpa lavada e desagregada vinda do "Scrubber" passa para um sistema de peneiramento primário e secundário de alta frequência.

No peneiramento primário acontece a primeira separação, aonde o material retido com diâmetro acima de $3.6 \mathrm{~mm}$ que possui valor agregado e é transportado para a pilha de estocagem de minério beneficiado

A polpa com granulometria abaixo de $3.6 \mathrm{~mm}$ continua para o peneiramento secundário que possui telas com abertura de $0.6 \mathrm{~mm}$. O material retido segue via correias transportadoras para as pilhas de material beneficiado.

O material com valor econômico retido no peneiramento primário e secundário é juntado e misturado nas pilhas estocáveis.

Este minério segue para a refinaria de alumina.

A polpa passante no peneiramento secundário, ou seja, com granulometria inferior a $0.6 \mathrm{~mm}$ é destinada como rejeito para a barragem. 


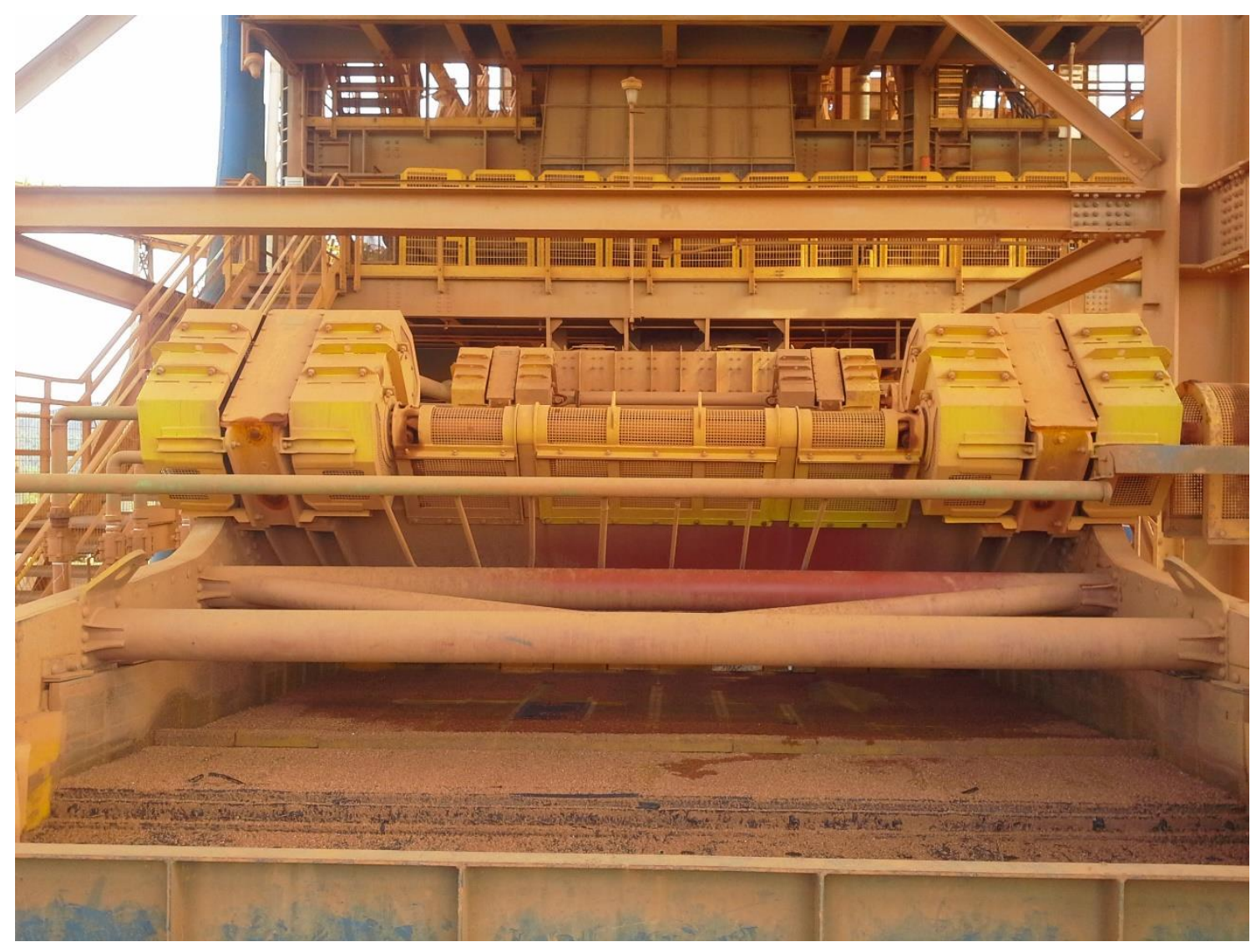

Figura 5-7 - Sistema de peneiramento - Unidade Miraí (Acervo pessoal, fev./2016).

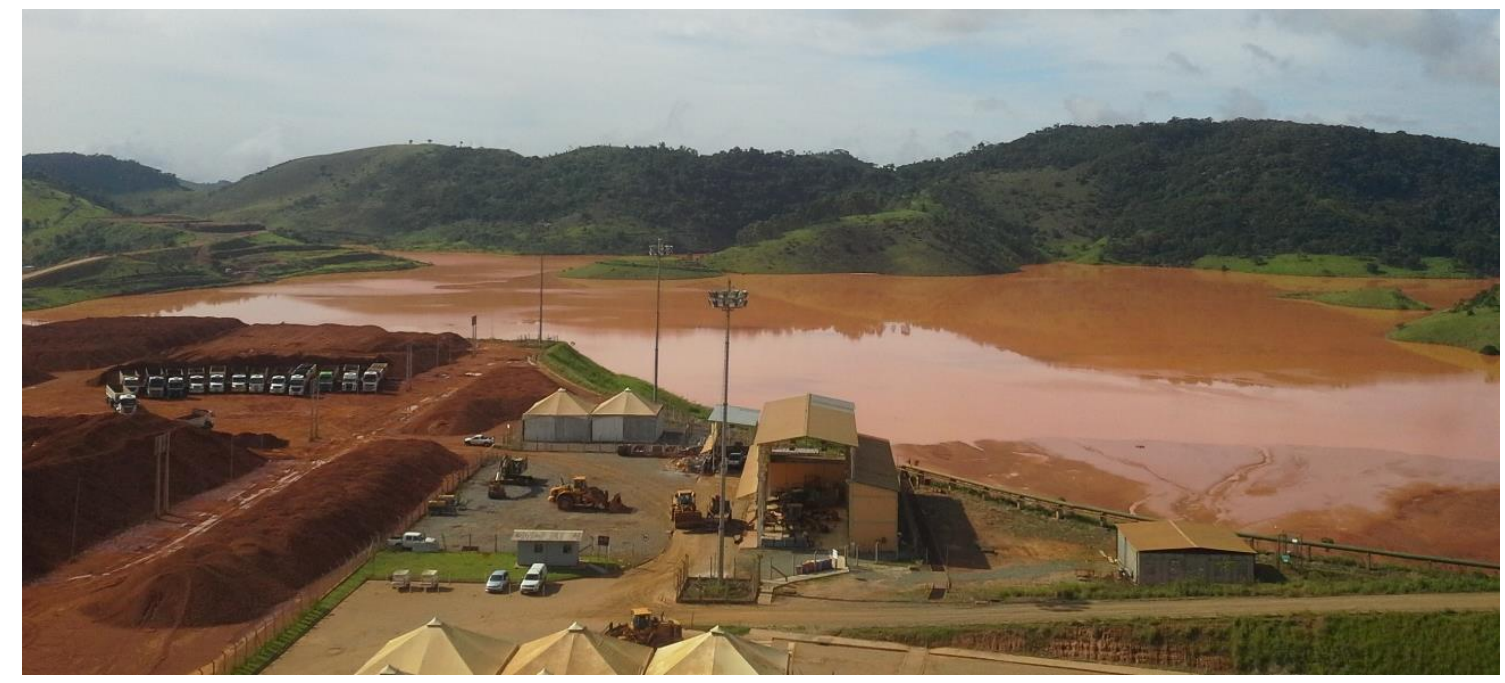

Figura 5-8 - Pilha da bauxita beneficiada e barragem de contenção do rejeito da bauxita lavada - Unidade Miraí (Fonte: Autor, fev./2016). 


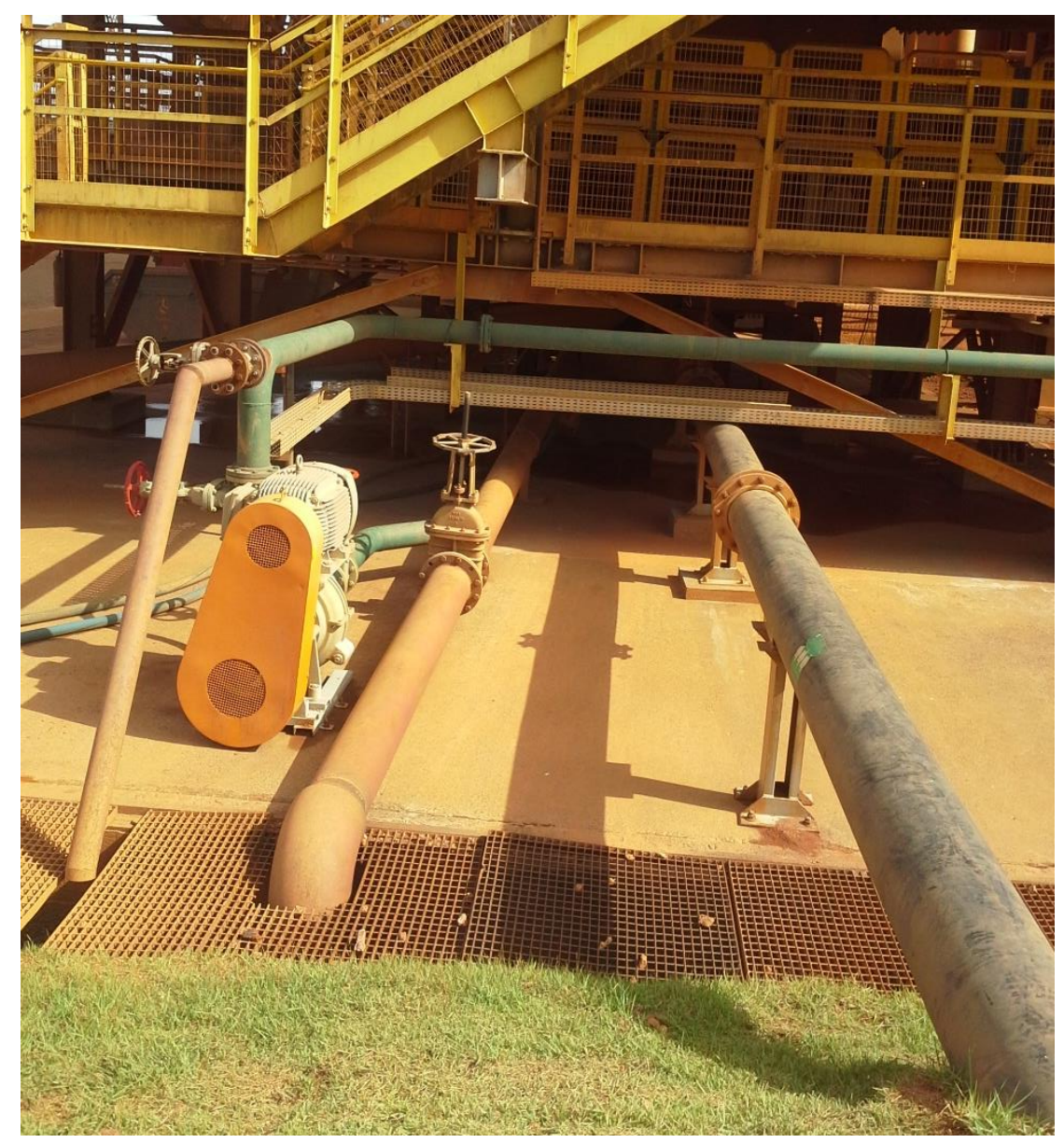

Figura 5-9 - Tubulações e caixa de passagem para conduzir os rejeitos de bauxita lavada para seu lançamento na barragem - Unidade Miraí (Acervo pessoal, fev./2016).

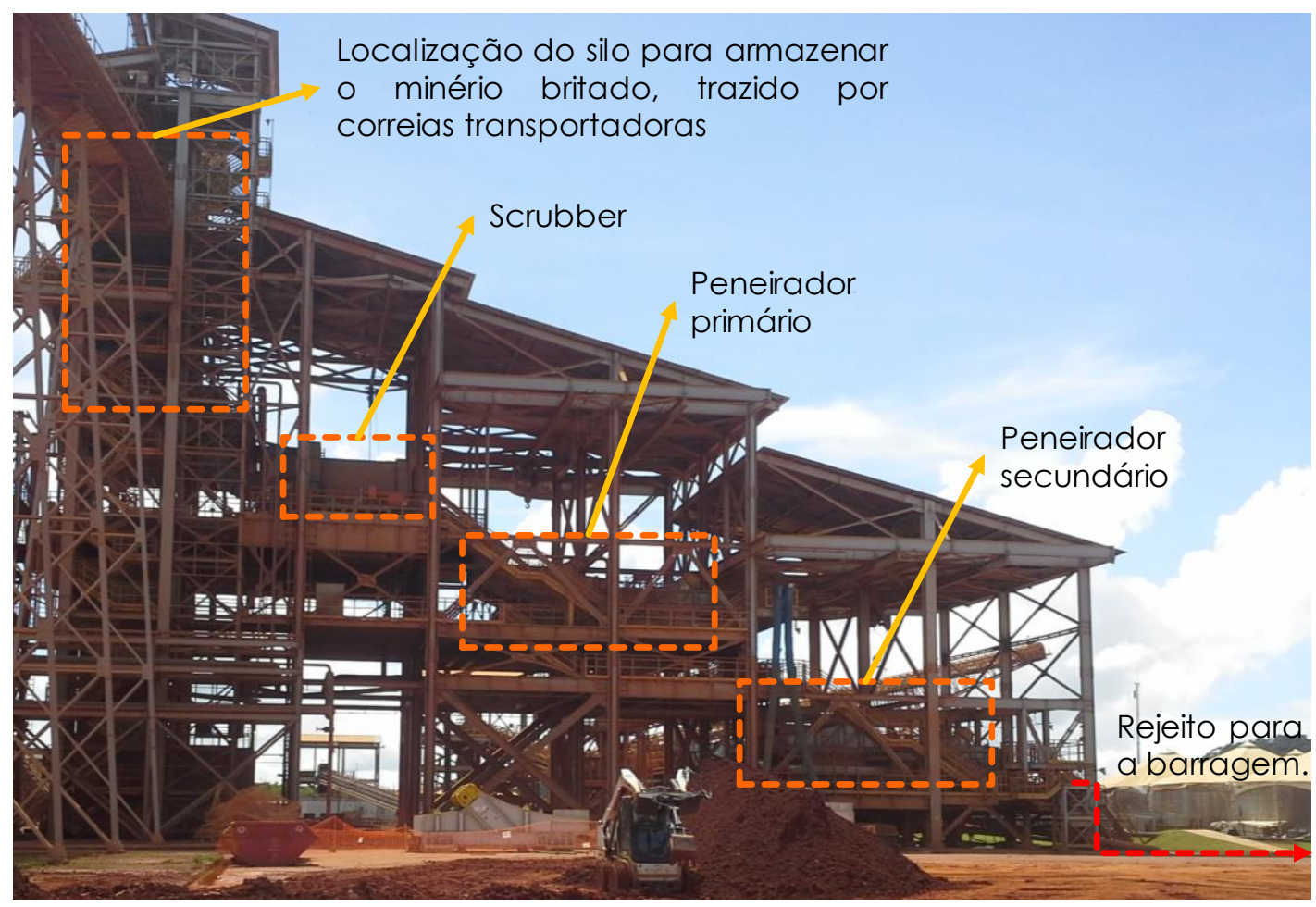

Figura 5-10 - Planta de beneficiamento, localização dos equipamentos de lavagem e classificação - Unidade Miraí (Acervo pessoal, fev./2016). 


\subsection{Locais de coleta}

Foram realizadas três coletas em diferentes locais no ano 2016, todos na região da Usina de Beneficiamento Miraí. Na Tabela 5-1 encontra-se a denominação das amostras com a nomenclatura utilizada em todas as análises, bem como a data de coleta.

Tabela 5-1 - Locais de coleta e denominação das três amostras estudadas.

\begin{tabular}{ccc}
\hline $\begin{array}{c}\text { Denominação da } \\
\text { amostra }\end{array}$ & Local de coleta & Data da coleta \\
\hline B-Mir01 & Praia de rejeitos & Fevereiro/2016 \\
B-Mir02 & Praia de rejeitos & Setembro/2016 \\
\hline B-Mir03 & $\begin{array}{c}\text { Planta de } \\
\text { beneficiamento }\end{array}$ & Setembro/2016 \\
\hline
\end{tabular}

O lançamento dos rejeitos da mineração de bauxita na Unidade Miraí é realizado hidraulicamente, por gravidade. A coleta dos materiais utilizados, foi realizada na praia de rejeitos, a localização pode ser visualizada na Figura 5-11 e Figura 5-12.

O material B-Mir01 foi coletado em fevereiro de 2016 na praia de rejeitos, no estado deformado, a uma distância aproximada de 15 metros do ponto de descarga, sendo coletados aproximadamente $15 \mathrm{~kg}$ de rejeitos, os quais foram transportados para o laboratório de Mecânica de solos da Escola Politécnica da Universidade de São Paulo.

As amostras B-Mir02 e B-Mir03 foram coletadas no mês de setembro de 2016 pelo próprio pessoal da Votorantim Metais armazenadas no interior tambor de ferro de aproximadamente 200 I e encaminhadas para o laboratório. As quantidades enviadas foram $25 \mathrm{~kg}$ para B-Mir02 e 30kg para B-Mir03.

Foi informado que a amostra B-Mir02 foi coletada na praia de rejeitos num local próximo ao ponto de descarga. Já a amostra B-Mir03, foi coletada na própria planta de beneficiamento, antes de ser lançada na barragem.

Já no laboratório, as amostras foram dispostas em recipientes adequados de modo a acelerar a secagem ao ar das mesmas para dar início aos ensaios de caracterização. 
A Figura 5-11 mostra uma vista da Mineração Miraí com a localização dos pontos de coleta. As amostras B-Mir01 e B-Mir02, coletados na praia de rejeitos, e a amostra B-Mir03 coletado na planta de beneficiamento antes do seu lançamento. A localização da Barragem e dos diques 01 e 02 pode ser observada também na figura. A Figura 5-12 mostra uma vista mais próxima da praia de rejeitos.

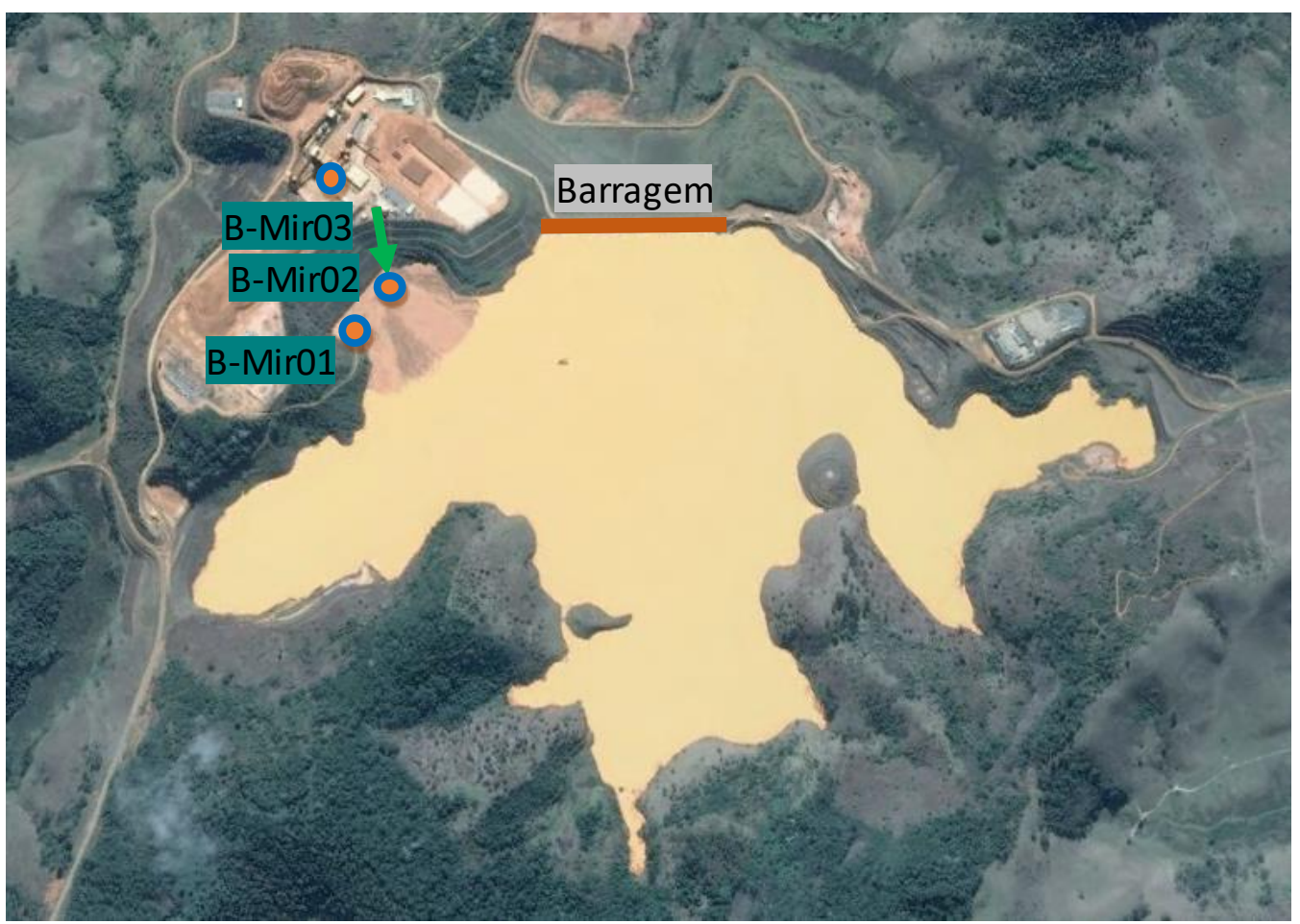

Figura 5-11 - Localização dos pontos de coleta das amostras na Mineração Miraí (Fonte: 2015 Digital Globe)

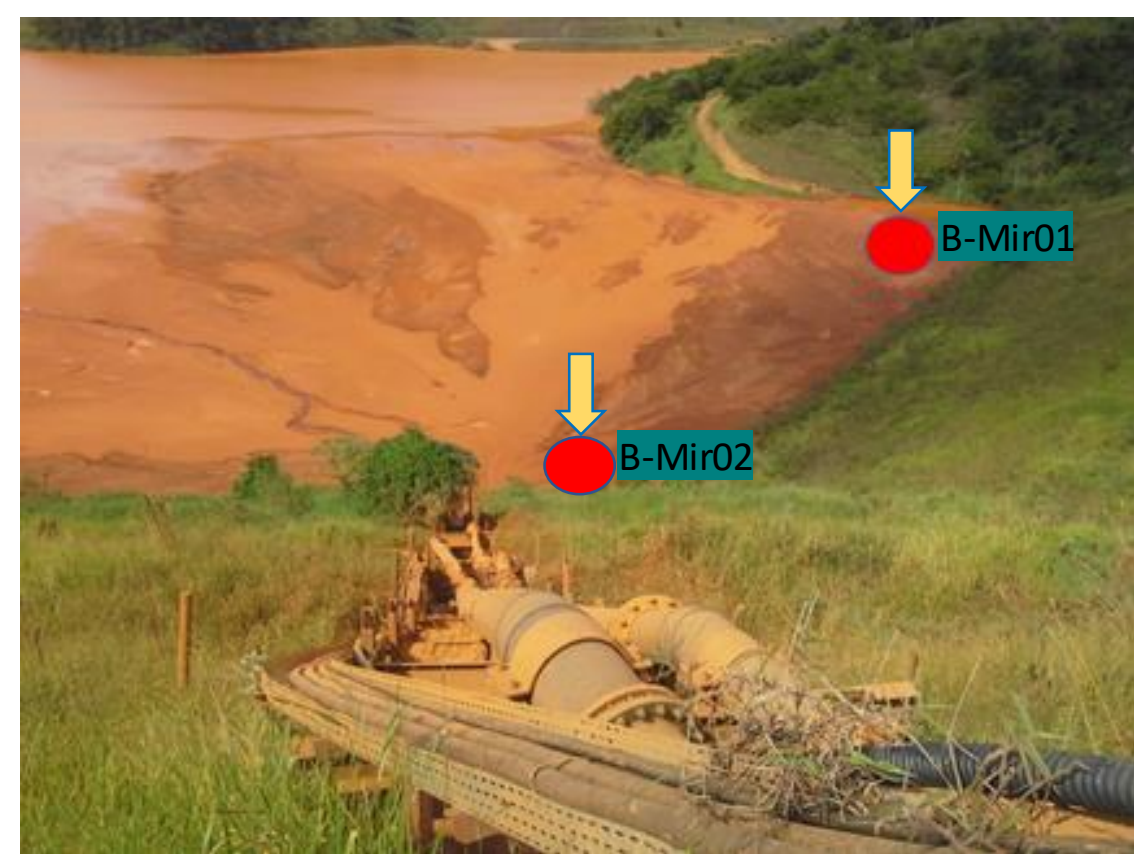

Figura 5-12- Pontos de coleta na praia de rejeitos (Acervo pessoal, fev. /2016). 
Também foi caracterizada uma amostra do próprio minério de Bauxita que foi denomina B-Mir-Ore, esta amostra já se encontrava no laboratório devido a estudos anteriores. A amostra do minério beneficiado encontrava-se armazenada no interior de um tambor de ferro. Nesta amostra de minério beneficiado somente foram realizados os ensaios de distribuição granulométrica e o ensaio para determinar a densidade especifica dos grãos, com a finalidade de realizar comparativos com as curvas granulométricas das amostras dos rejeitos. Sua caracterização mineralógica foi determinada também a partir da fluorescência e difratometria de raios $\mathrm{x}$. 


\section{CARACTERIZAÇÃo MINERALÓGICA}

6.1 Análise de fluorescência de raios $\mathrm{x}$.

Esta técnica analítica quantitativa é a mais empregada na análise dos componentes maiores de materiais geológicos. Tem alta precisão e boa reprodutibilidade. Seu uso é recomendado quando é conhecido o material a ser analisado.

Para determinar a composição química das amostras em estudo os teores apresentados foram determinados em amostra fundida com tetraborato de lítio anidro, na calibração BAX-2 (bauxitas), relativa a análise quantitativa por comparação com materiais de referência certificados, em espectrômetro de fluorescência de raios $X$, marca Bruker, modelo S8 Tiger. A perda ao fogo (PF) foi efetuada a $1.020^{\circ} \mathrm{C}$ por $2 \mathrm{~h}$.

Os resultados obtidos para as amostras de rejeito B-Mir01, B-Mir02 e B-Mir03, e para o minério bauxita lavada estão apresentados na Tabela 6-1.

Tabela 6-1 - Resultados de fluorescência de raios $x$ para as amostras em estudo.

\begin{tabular}{|c|c|c|c|c|}
\hline \multirow[b]{2}{*}{$\begin{array}{l}\text { Composto } \\
\text { químico }\end{array}$} & \multicolumn{4}{|c|}{ Amostra } \\
\hline & $\begin{array}{c}\text { B-Mir-Ore } \\
(\%)\end{array}$ & $\begin{array}{c}\text { B-Mir01 } \\
(\%)\end{array}$ & $\begin{array}{c}\text { B-Mir02 } \\
(\%)\end{array}$ & $\begin{array}{c}\text { B-Mir03 } \\
(\%)\end{array}$ \\
\hline $\mathrm{Al}_{2} \mathrm{O}_{3}$ & 48.5 & 29.1 & 28.5 & 29.7 \\
\hline $\mathrm{Fe}_{2} \mathrm{O}_{3}$ & 15.4 & 13.1 & 19.0 & 29.5 \\
\hline $\mathrm{SiO}_{2}$ & 6.91 & 37.2 & 31.0 & 15.4 \\
\hline $\mathrm{TiO}_{2}$ & 2.06 & 2.62 & 3.80 & 6.13 \\
\hline $\mathrm{P}_{2} \mathrm{O}_{5}$ & 0.26 & 0.26 & 0.29 & 0.38 \\
\hline $\mathrm{CaO}$ & $<0.10$ & $<0.10$ & $<0.10$ & $<0.10$ \\
\hline $\mathrm{V}_{2} \mathrm{O}_{5}$ & 0.04 & 0.05 & 0.08 & 0.12 \\
\hline $\mathrm{Cr}_{2} \mathrm{O}_{3}$ & 0.03 & 0.01 & 0.06 & 0.03 \\
\hline MnO & $<0.10$ & $<0.10$ & $<0.10$ & $<0.10$ \\
\hline $\mathrm{ZrO}_{2}$ & $<0.10$ & $<0.10$ & 0.16 & 0.11 \\
\hline $\mathrm{MgO}$ & $<0.10$ & $<0.10$ & $<0.10$ & $<0.10$ \\
\hline $\mathrm{K}_{2} \mathrm{O}$ & $<0.10$ & $<0.10$ & $<0.10$ & $<0.10$ \\
\hline $\mathrm{Na}_{2} \mathrm{O}$ & $<0.10$ & $<0.10$ & $<0.10$ & $<0.10$ \\
\hline $\begin{array}{l}\text { Perda ao } \\
\text { fogo (PF) }\end{array}$ & 27.0 & 17.8 & 16.9 & 18.3 \\
\hline
\end{tabular}


6.2 Análise por difratometria de raios $\mathrm{x}$

Foram realizados os ensaios por difração de raios $x$ no Laboratorio de caracterização tecnológica (LCT) da Poli-Minas.

As Figuras 6.1 até a 6.4 apresentam os resultados obtidos.
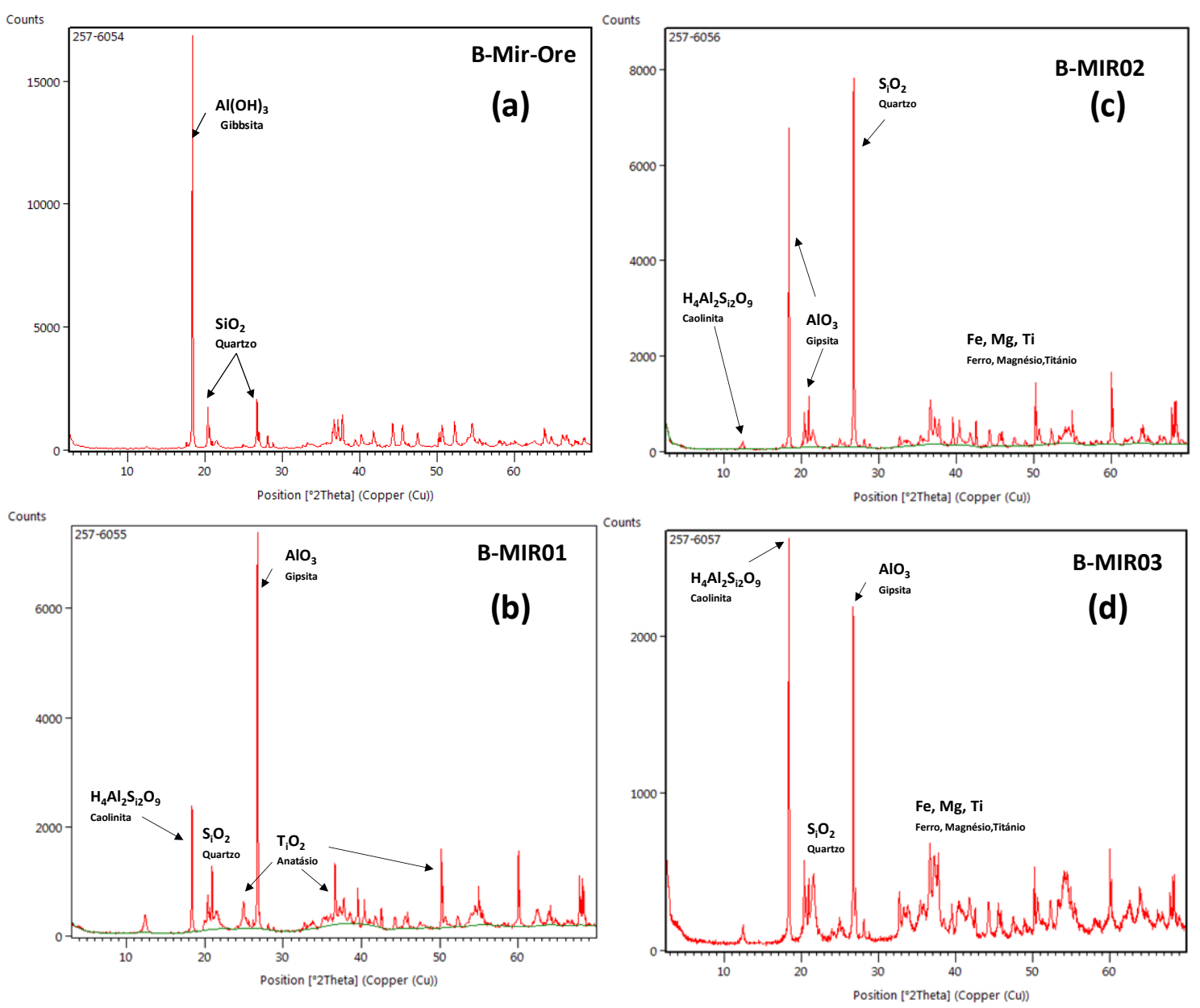

Figura 6-1 - Difratogramas de raios X. (a) B-Mir-Ore. (b) B-Mir01. (c) B-Mir02. (d) B-Mir03. 


\section{CARACTERIZAÇÃO GEOTÉCNICA}

Uma serie de ensaios de laboratório foram realizados com a finalidade de determinar a natureza e propriedades geotécnicas do rejeito de bauxita. Foram determinados:

- A densidade dos grãos;

- A distribuição granulométrica;

- Os limites de consistência e;

- As curvas de compactação.

Também foram realizados ensaios especiais de adensamento e triaxiais.

Para realizar os ensaios de caracterização das três amostras de rejeito, o material foi preparado seguindo as recomendações da NBR 6457:2016. Todas as amostras foram secas ao ar, destorroadas e homogeneizadas como visto na Figura 7-1 para a amostra B-Mir03.

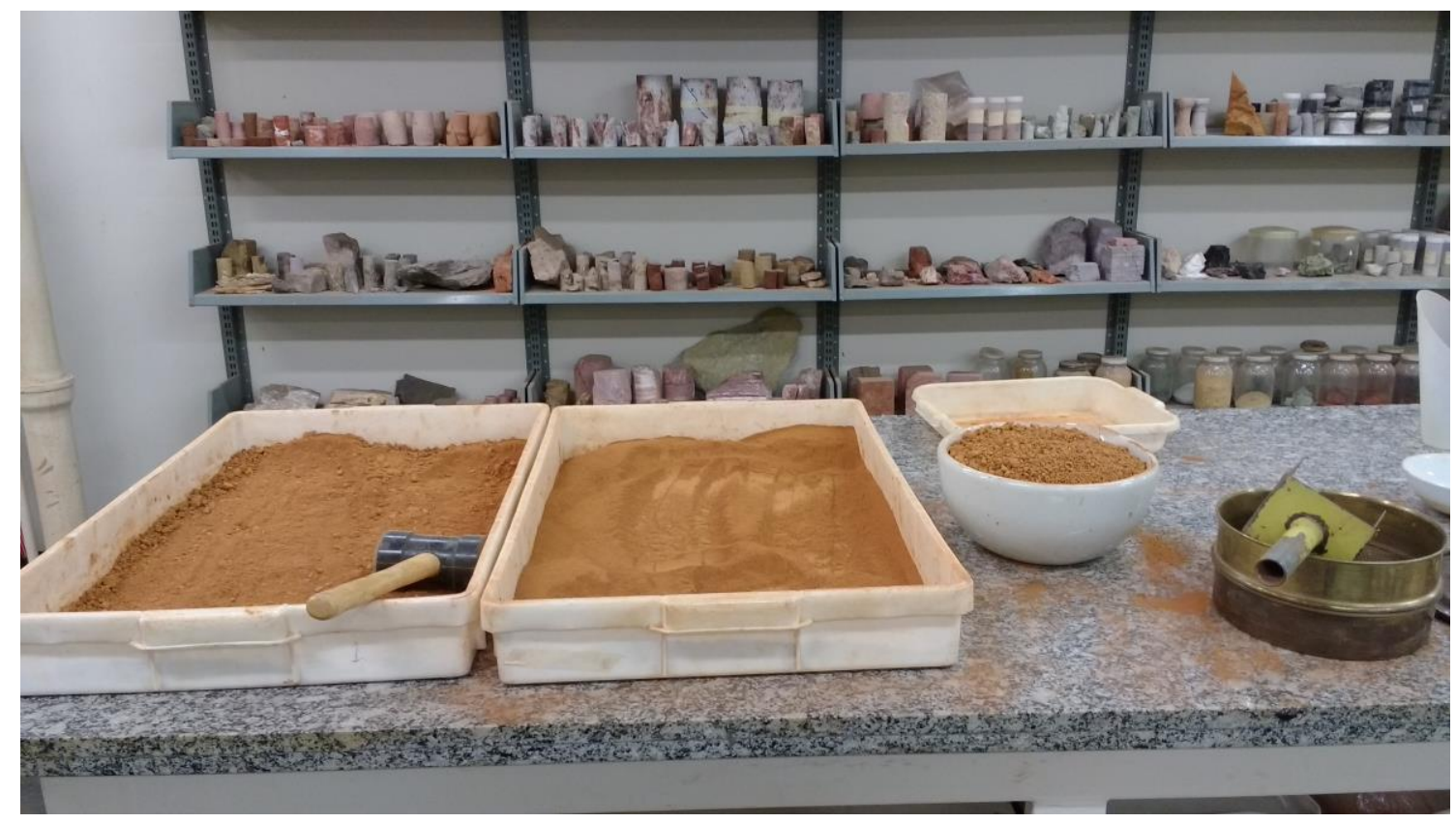

Figura 7-1 - Preparação do rejeito-Mir03 para iniciar os ensaios de caracterização.

A

Tabela 7-1 apresenta as normas vigentes brasileiras utilizadas para cada um dos ensaios de caracterização. 
Tabela 7-1 - Normas brasileiras para realização de ensaios de caracterização

\begin{tabular}{ccc}
\hline Ensaio & Procedimento & Observação \\
\cline { 1 - 2 } Densidade dos grãos & ABNT NBR 6458:2016 & \\
\cline { 1 - 2 } Análise granulométrica & ABNT NBR 7181:2016 & Amostras preparadas para \\
\cline { 1 - 2 } Limites de liquidez & ABNT NBR 6459:2016 & cada ensaio conforme ABNT \\
\cline { 1 - 2 } Limites de plasticidade & ABNT NBR 7180:2016 & NBR 6457:2016 \\
\cline { 1 - 2 } Ensaio de compactação & ABNT NBR 7182:2016 & \\
\hline
\end{tabular}

\subsection{Ensaios de granulometria e limites de consistência}

Para determinar a natureza do rejeito foram realizados: $O$ ensaio de análise granulométrica e limites de Atterberg e determinação do peso específico dos grãos

Dois ensaios de sedimentação para determinação da distribuição granulométrica foram executados:

- Um com acréscimo de defloculante, no caso $125 \mathrm{ml}$ de hexametafosfato de potássio;

- O segundo sem acréscimo de defloculante;

Este procedimento teve como objetivo comparar os efeitos químicos do defloculante na separação dos grãos do material ensaiado e permitir uma avaliação da dispersividade do material.

A Figura 7-2 apresenta as curvas granulométricas das amostras estudadas: BMir01, B-Mir02 e B-Mir03 (Rejeitos) e B-Mir-Ore (minério Bauxita). Nestes ensaios foi utilizado o defloculante. Nesta figura se observa que as amostras BMir01 e B-Mir03 apresentaram maior porcentagem de finos na sua composição sendo $62 \%$ e $74 \%$ respectivamente. A amostra B-Mir02 apresenta maior porcentagem de areia com $62 \%$ da sua composição e $38 \%$ de finos. Finalmente o minério bauxita beneficiada com $92.4 \%$ de fração grossa $(65 \%$ acima da peneira \#4). 


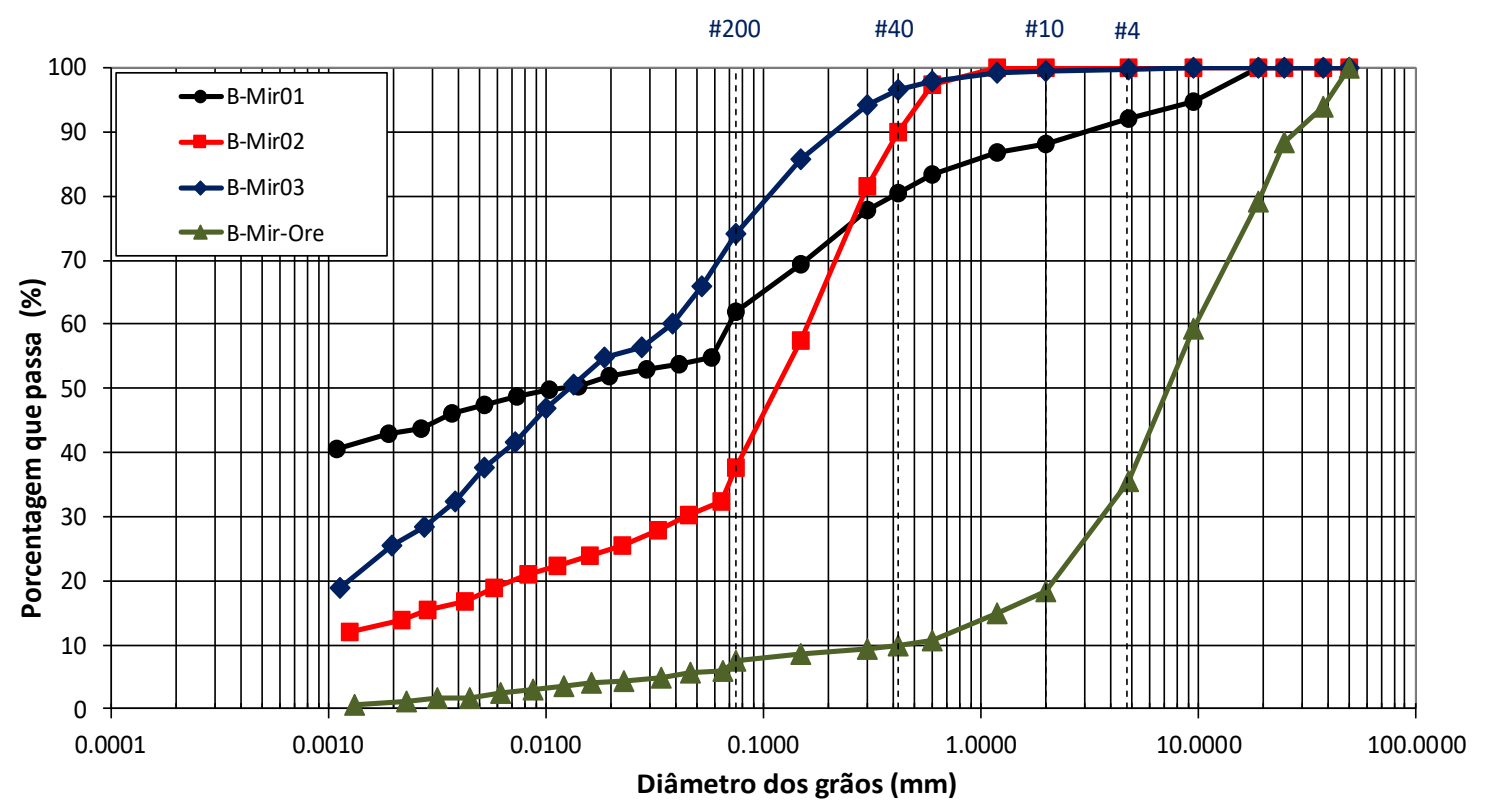

Figura 7-2 - Curva granulométrica do rejeito de mineração de bauxita, com defloculante.

Com o objetivo de avaliar uma eventual dispersão do material foram realizados ensaios de granulometria sem defloculante. A Figura 7-3 apresenta os resultados da granulometria utilizando-se os dois processos, com e sem defloculante. Observa-se que as amostras não se apresentam como dispersivas por este procedimento.

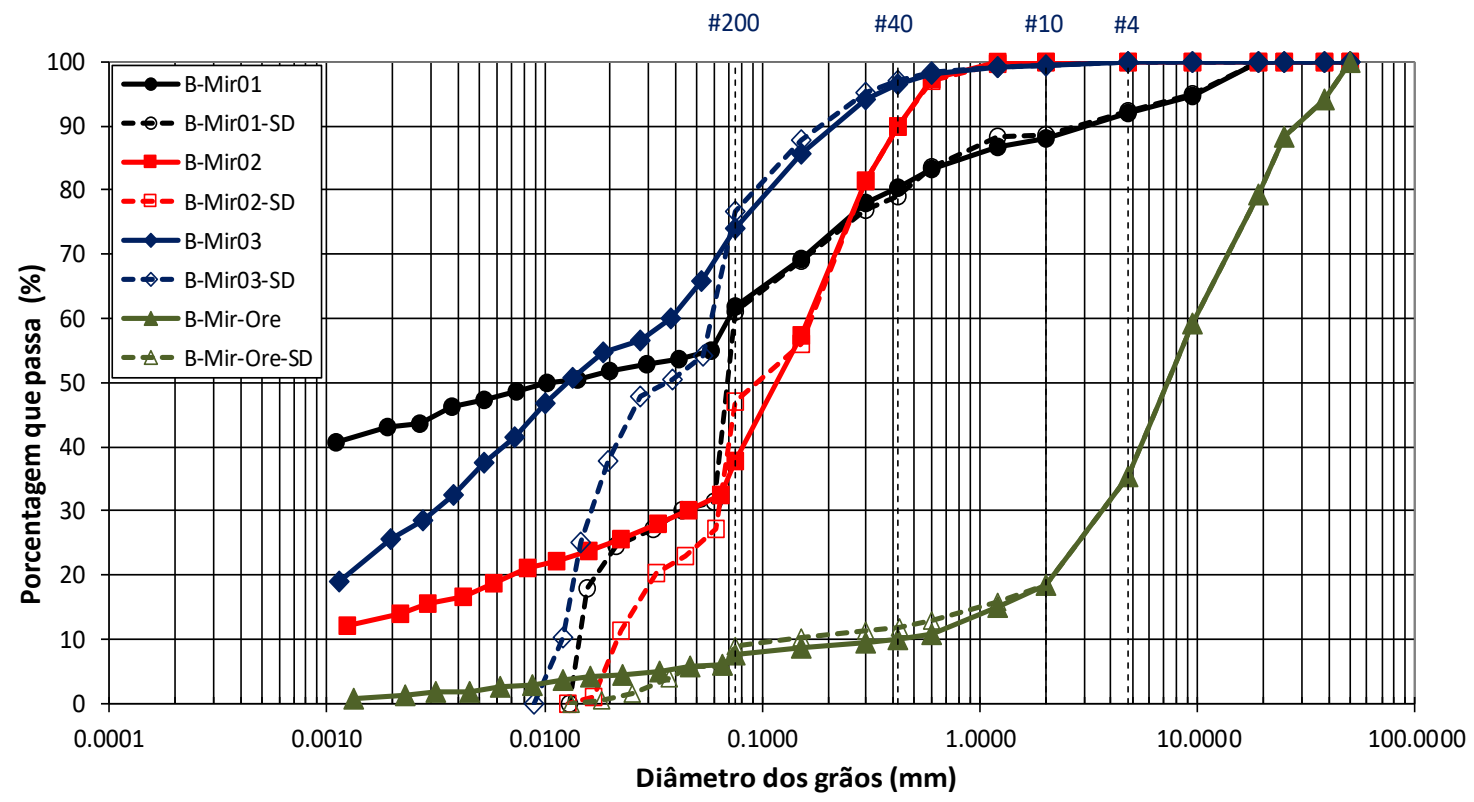

Figura 7-3 - Curva granulométrica do rejeito de mineração de mauxita com e sem defloculante.. 
A Figura 7-4 apresenta a carta de plasticidade com o resultado obtidos para as amostras B-Mir01 e B-Mir03. A amostra B-Mir01 apresenta o comportamento de uma argila de baixa plasticidade (CL), já a amostra B-Mir03 se apresenta como um silte de baixa plasticidade (ML). A amostra B-Mir02 não apresentou plasticidade apesar de apresentar porcentagem de finos de $38 \%$.

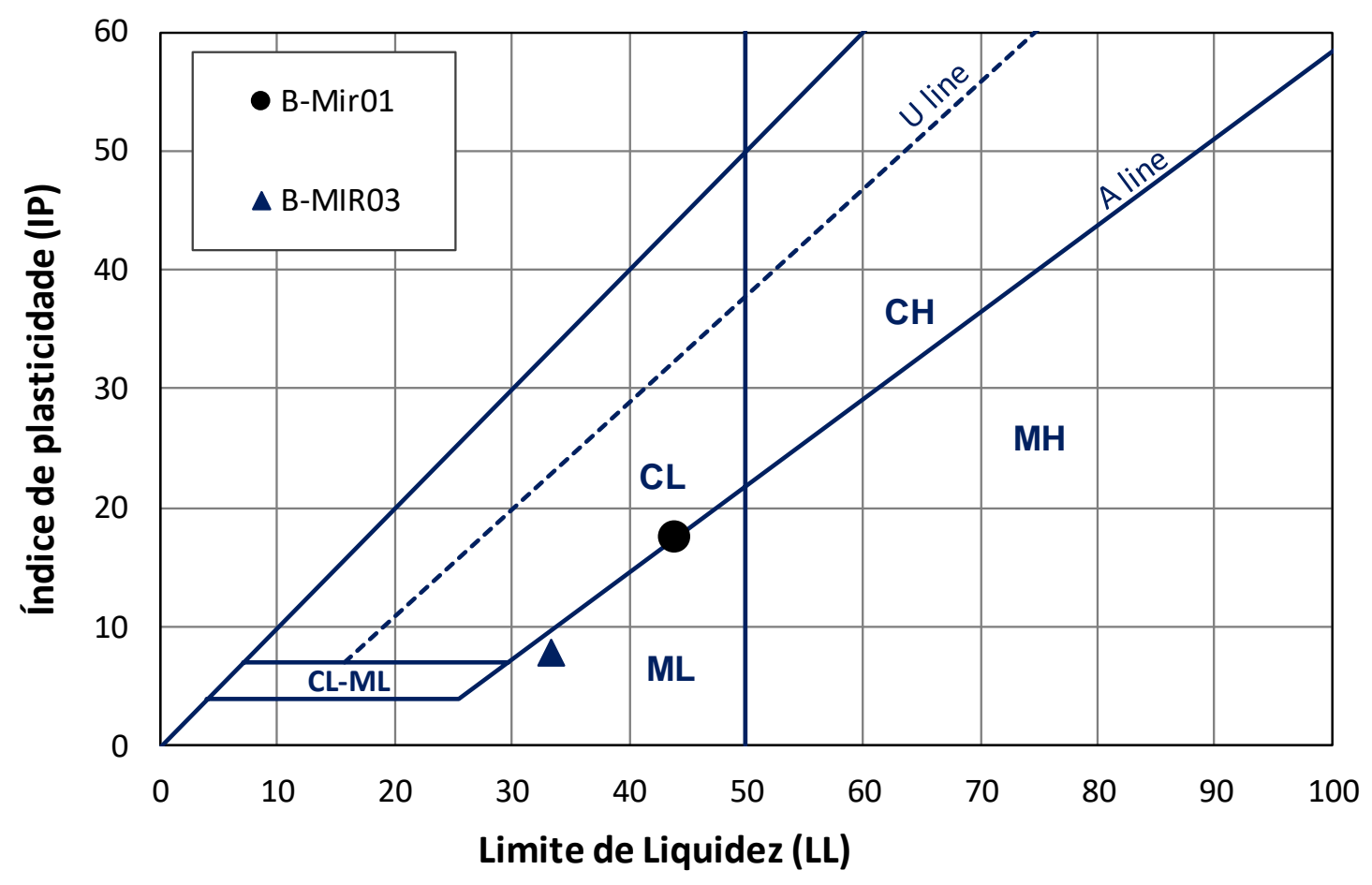

Figura 7-4 - Carta de Plasticidade de Casagrande

O resumo dos resultados dos ensaios de caracterização está apresentado na Tabela 7 2. Foram ensaiados as três amostras de rejeito e o próprio minério beneficiado, como referência. 
Tabela 7-2 - Características do rejeito obtidas no laboratório

\begin{tabular}{|c|c|c|c|c|}
\hline Características & B-Mir01 & B-Mir02 & B-Mir03 & B-Mir-Ore \\
\hline \% Pedregulho & 8.0 & 0.0 & 0.0 & 65.0 \\
\hline$\%$ Areia & 30.0 & 62.0 & 27.0 & 27.4 \\
\hline$\%$ Finos & 62.0 & 38.0 & 74.0 & 7.6 \\
\hline$\%<2 \mu \mathrm{mm}$ & 43.0 & 13.5 & 25.5 & 1.2 \\
\hline $\begin{array}{l}\text { Limite de liquidez } \\
\qquad(\%)\end{array}$ & 44.0 & NP & 33.0 & NP \\
\hline $\begin{array}{l}\text { Limite de } \\
\text { plasticidade (\%) }\end{array}$ & 26.0 & NP & 26.0 & NP \\
\hline $\begin{array}{c}\text { Índice de } \\
\text { plasticidade (\%) }\end{array}$ & 18.0 & NP & 8.0 & NP \\
\hline $\begin{array}{l}\text { Densidade dos } \\
\text { grãos }\left(\mathrm{g} / \mathrm{cm}^{3}\right)\end{array}$ & 2.71 & 2.79 & 2.98 & 2.64 \\
\hline $\mathrm{D}_{10}(\mathrm{~mm})$ & $<0.001$ & $<0.001$ & $<0.001$ & 0.4 \\
\hline $\mathrm{D}_{30}(\mathrm{~mm})$ & $<0.001$ & 0.046 & 0.003 & 3.6 \\
\hline $\mathrm{D}_{50}(\mathrm{~mm})$ & 0.01 & 0.12 & 0.013 & 7.2 \\
\hline $\mathrm{D}_{60}(\mathrm{~mm})$ & 0.07 & 0.16 & 0.038 & 9.6 \\
\hline $\mathrm{pH}$ & 4 & 5 & 5 & 5 \\
\hline $\begin{array}{c}\text { Classificação } \\
\text { SUCS }\end{array}$ & $\mathrm{CL}$ & SM & ML & GP-GM \\
\hline Nome SUCS & $\begin{array}{c}\text { Argila de } \\
\text { baixa } \\
\text { plasticidade } \\
\text { arenosa }\end{array}$ & $\begin{array}{l}\text { Areia } \\
\text { siltosa }\end{array}$ & $\begin{array}{l}\text { Silte com } \\
\text { areia }\end{array}$ & $\begin{array}{l}\text { Pedregulho mal } \\
\text { graduado com } \\
\text { silte e areia }\end{array}$ \\
\hline
\end{tabular}

\subsection{Curva de Compactação}

Para determinação das curvas de compactação das três amostras de rejeito seguiram-se as recomendações da ABNT NBR 7182/2016 para realizar o ensaio de compactação Proctor normal com reuso de material.

Para iniciar o ensaio foram separados $3 \mathrm{~kg}$ de material, de cada amostra de rejeito seco ao ar, rejeito que foi homogeneizado e passado na peneira no. 4 $(4.75 \mathrm{~mm})$.

No ensaio Proctor Normal, inicialmente, para determinar os pontos que vão formar a curva, o rejeito foi umedecido e depositado num molde de aproximadamente $1000 \mathrm{~cm}^{3}$. O rejeito foi compactado em três camadas iguais com auxílio de um soquete aonde foram aplicados 26 golpes por camada. 
A Figura 7-5 contém as três curvas de compactação obtidas para as amostras: B-Mir01, B-Mir02 e B-Mir03.

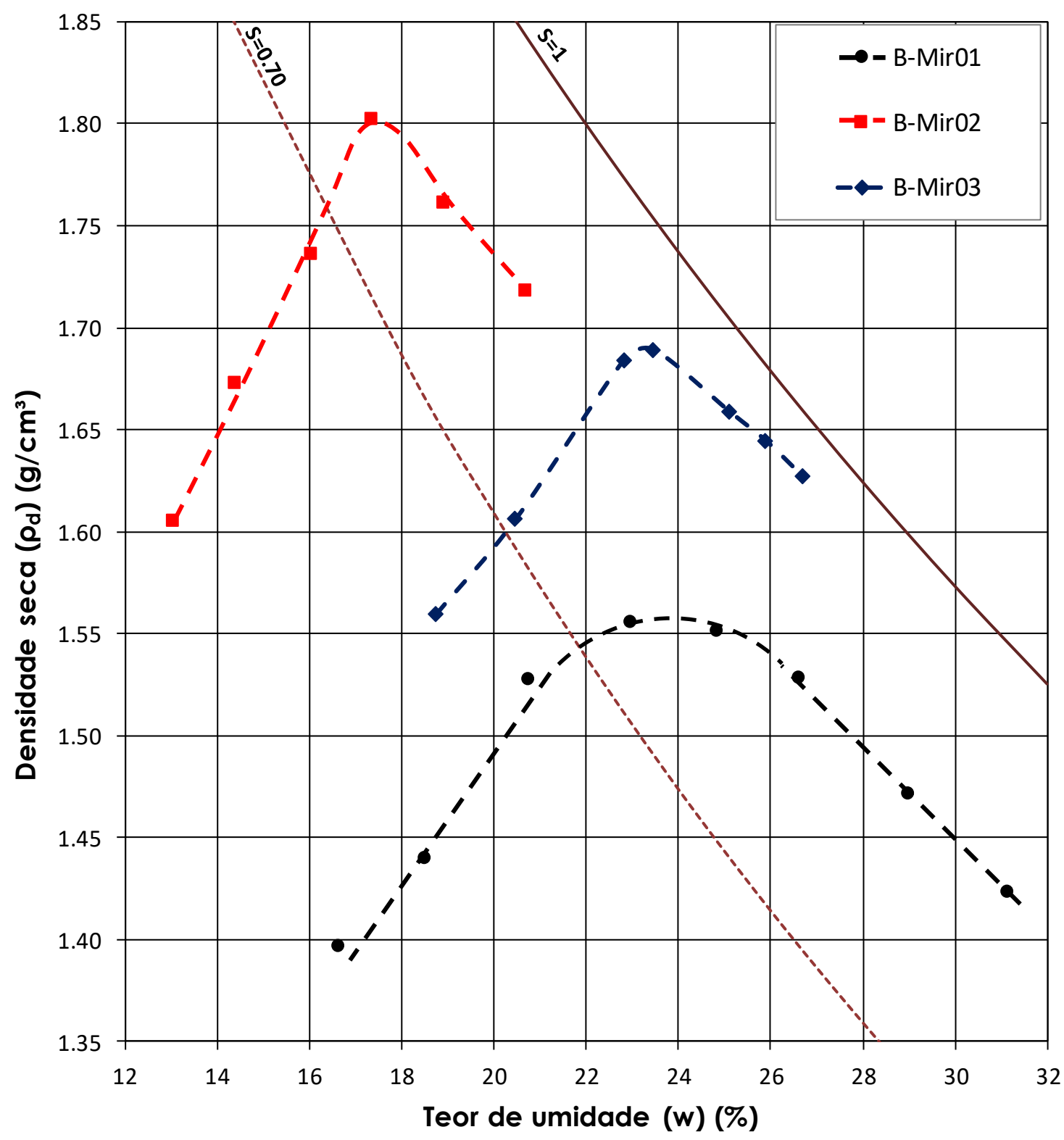

Figura 7-5 - Curva de Compactação obtida para três amostras de rejeito de bauxita

A Tabela 7-3, apresenta os valores de umidade ótima e densidade seca máxima correspondente para cada amostra de rejeito, obtidos a partir curvas de compactação.

Tabela 7-3 - Características de compactação das três amostras de rejeito.

\begin{tabular}{cccc}
\hline & B-Mir01 & B-Mir02 & B-Mir03 \\
\hline Densidade seca máxima $\left(\mathrm{g} / \mathrm{cm}^{3}\right)$ & 1.56 & 1.80 & 1.69 \\
Teor de umidade ótima $(\%)$ & 23.7 & 17.5 & 23.3 \\
\hline
\end{tabular}




\section{ENSAIOS ESPECIAIS}

\subsection{Pontos de estudo}

Determinadas as curvas de compactação para cada amostra de rejeito, foram escolhidos três pontos de estudo em cada uma das curvas de compactação como observado na Figura 8-1. Foi escolhido um ponto no ramo seco, um na umidade ótima e outro no ramo úmido. Os pontos com teor de umidade menor que a ótima, são identificados com a letra $\mathrm{D}$, aquele na ótima com a letra $\mathrm{O}$ e o ponto acima do teor de umidade ótimo com a letra W.

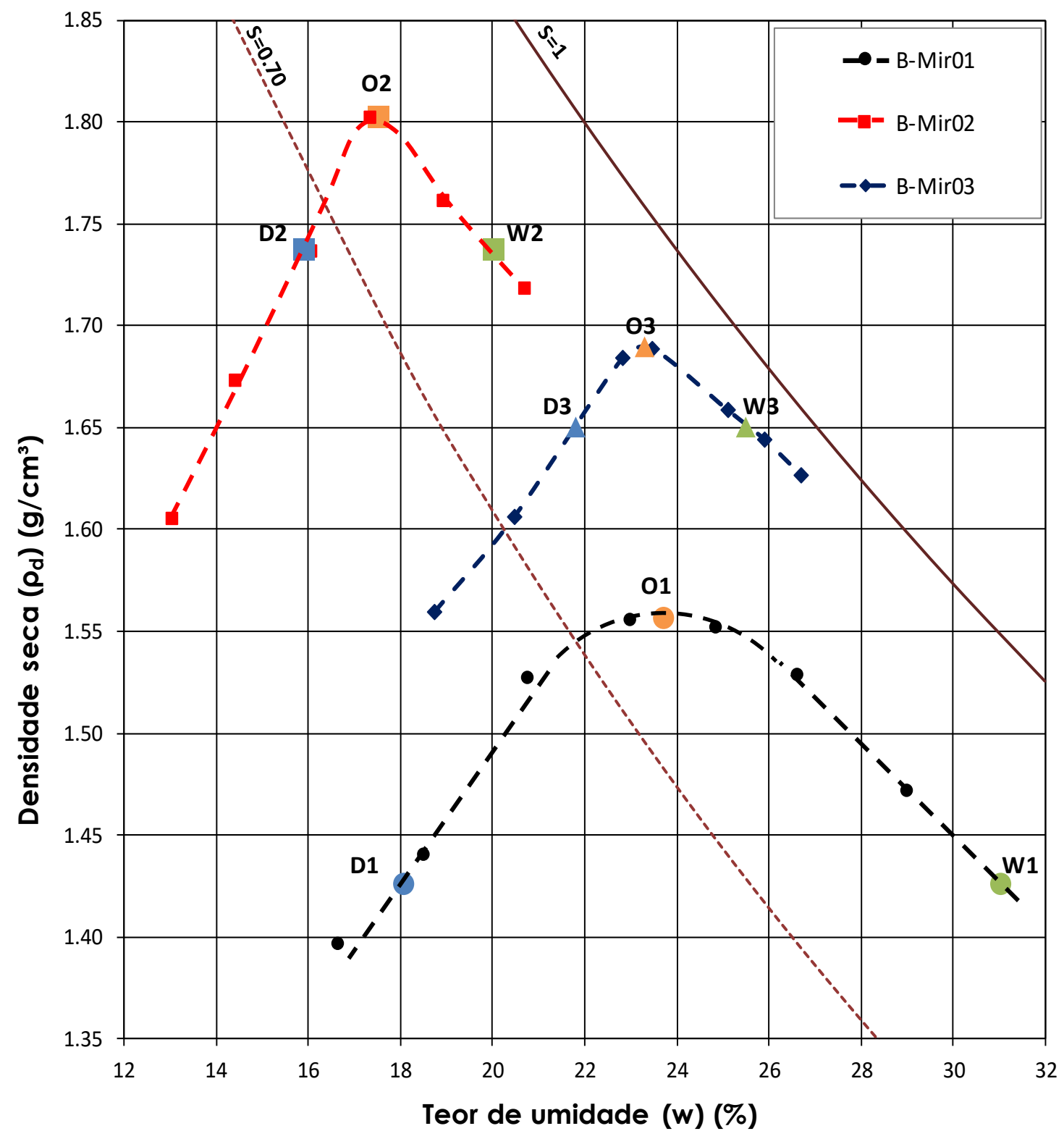

Figura 8-1 - Pontos de estudo na curva de compactação do rejeito de bauxita em estudo. 
A escolha destes pontos teve como objetivo de estudar a resistência ao cisalhamento e compressibilidade do rejeito com diferentes umidades. Para isto foram realizados ensaios de adensamento oedométrico e ensaios triaxiais de resistência não drenada.

A Tabela 8-1 mostra as características iniciais dos pontos de estudo escolhidos. Aonde:

- w (\%) - Teor de umidade

- $\quad \rho d\left(\mathrm{~g} / \mathrm{cm}^{3}\right)$ - Densidade seca

- e - Índice de vazios

- $S(\%)$ - Grau de saturação

Tabela 8-1 - Características iniciais dos pontos de estudo.

\begin{tabular}{ccccc}
\hline Pontos & $\mathbf{w}(\%)$ & $\boldsymbol{\rho}_{\mathbf{d}}\left(\mathbf{g} / \mathbf{c m}^{\mathbf{3}}\right)$ & $\mathbf{e}$ & $\mathbf{S}(\%)$ \\
\hline $\mathbf{D 1}$ & 18.05 & 1.426 & 0.90 & 54.33 \\
\hline 01 & 23.7 & 1.557 & 0.74 & 86.73 \\
\hline W1 & 31.0 & 1.426 & 0.90 & 93.30 \\
\hline D2 & 15.9 & 1.738 & 0.61 & 73.29 \\
\hline O2 & 17.5 & 1.803 & 0.55 & 89.19 \\
\hline W2 & 20.0 & 1.738 & 0.61 & 92.19 \\
\hline D3 & 21.8 & 1.650 & 0.81 & 80.59 \\
\hline O3 & 23.3 & 1.690 & 0.76 & 90.96 \\
\hline W3 & 25.5 & 1.650 & 0.81 & 94.27
\end{tabular}

Obs.: Os pontos no ramo seco e no ramo úmido possuem a mesma densidade seca.

\subsection{Ensaio oedômetrico e permeabilidade}

Com a finalidade de obter os parâmetros de compressibilidade na Figura 7-6 se apresentam três curvas de adensamento, onde se observa o comportamento do índice de vazios (e) em função da tensão vertical aplicada $\left(\sigma_{\mathrm{v}}\right)$, para isto foram aplicados 9 estágios de carregamento (10, 20, 40, 80, 160,320, 640, 1280 e $2560 \mathrm{kPa})$ e 08 estágios de descarregamento ( $-2560,-1280,-640,-320,-160$, $80,-40,-20 \mathrm{kPa})$.

Cada curva corresponde a uma condição de umidade, no ramo seco, na umidade ótima e no ramo úmido 


\subsubsection{Moldagem dos corpos de prova}

Os corpos de prova foram moldados por meio de compactação estática diretamente no anel de adensamento com auxílio de gabarito e prensa hidráulica. As dimensões do molde são: $7 \mathrm{~cm}$ de diâmetro e $2 \mathrm{~cm}$ de altura. O material foi homogeneizado e compactado com um teor de umidade de acordo com o indicado na Tabela 8-1. Após a compactação o material uma vez na célula de adensamento, foi submetido a uma carga inicial de $10 \mathrm{kPa}$ e simultaneamente inundado.

\subsubsection{Resultados dos ensaios edométricos}

Na Figura 8-2 estão apresentadas as curvas de adensamento da amostra BMir01, compactadas nos teores de umidade pré-estabelecidos. Salienta-se que o corpo de prova D1 apresentou expansão de $1.3 \%$ sob o carregamento de 10 $\mathrm{kPa}$. Os demais não apresentaram este comportamento.

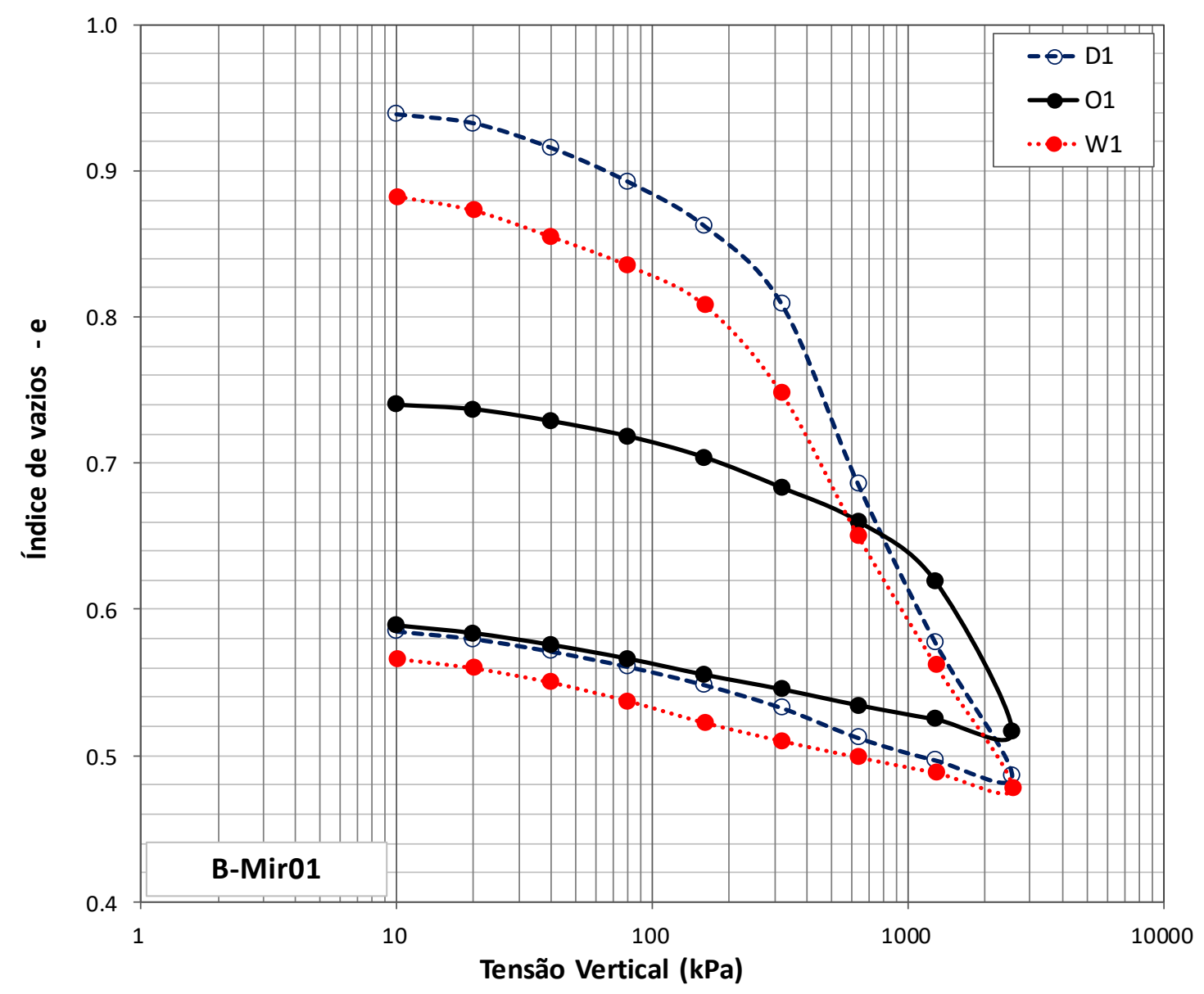

Figura 8-2 - Resultados ensaio oedométrico para o rejeito B-Mir01. 
$\mathrm{Na}$ Figura 8-3 tem-se os resultados do adensamento para as amostras B-Mir02. A forma da curva reflete as características granulométricas do material. A Figura 8-4 apresenta os resultados obtidos para a amostra B-Mir03.

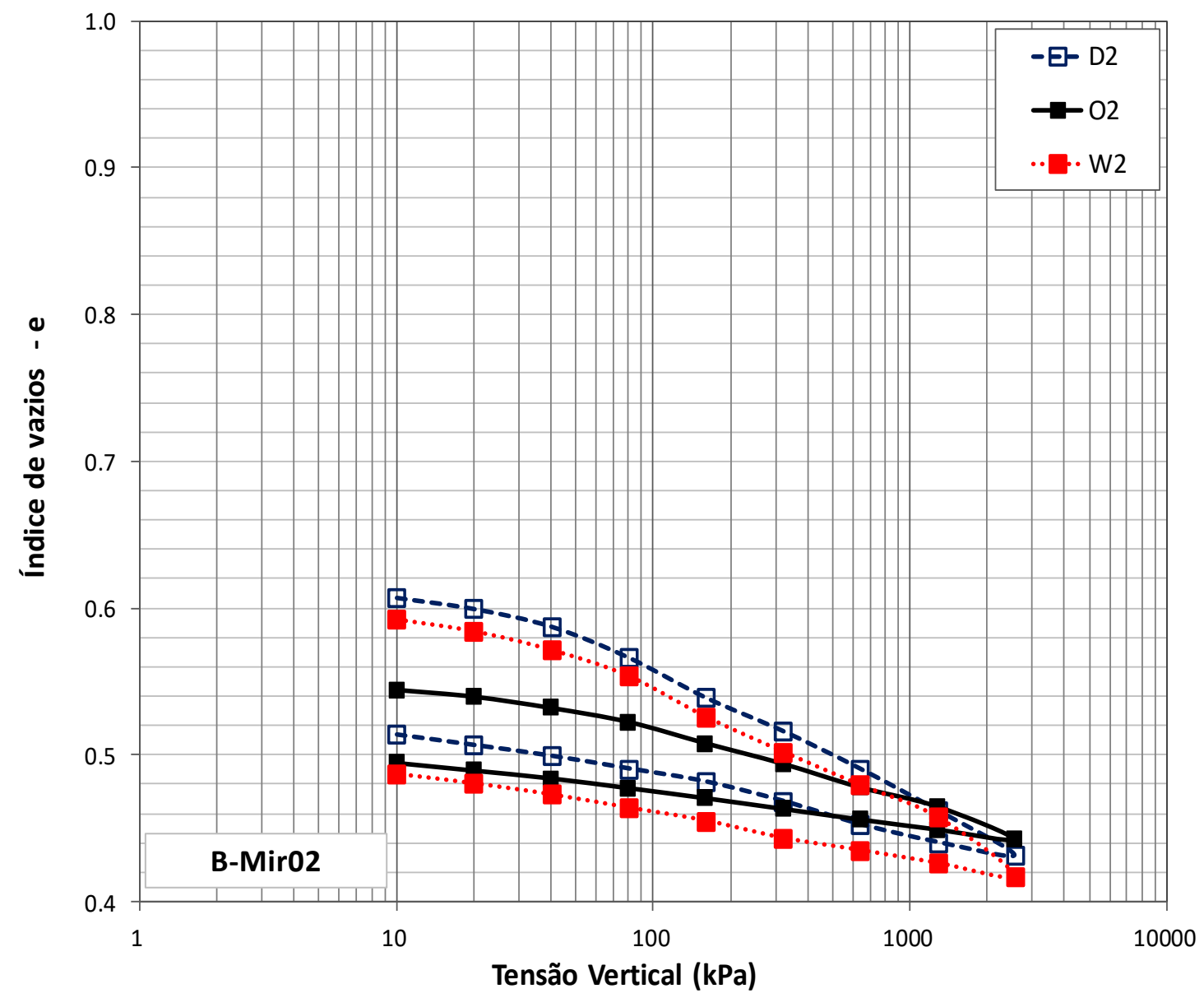

Figura 8-3 - Resultados ensaio oedométrico para o rejeito B-Mir02. 


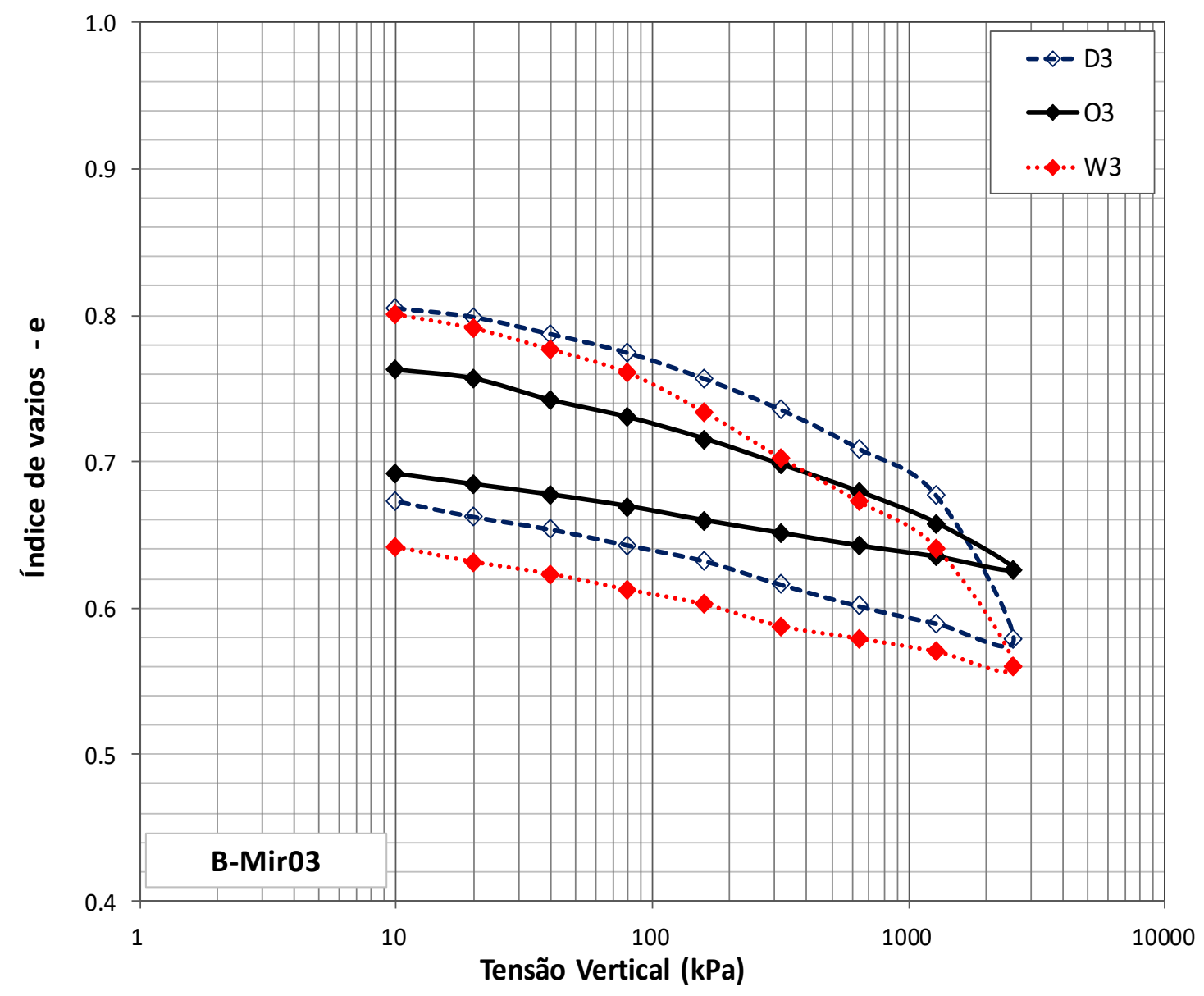

Figura 8-4 - Resultados ensaio oedométrico para o rejeito B-Mir03.

Na Tabela 8-2 estão apresentados os valores dos índices obtidos nos ensaios.

Tabela 8-2 - Índice de recompressão ( $\mathrm{Cr}$ ), compressão $(\mathrm{Cc})$ e de expansão $(\mathrm{Ce})$ das amostras B-Mir01, B-Mir02 e B-Mir03.

\begin{tabular}{cccc}
\hline Corpo de prova & $\mathrm{Cr}$ & $\mathrm{Cc}$ & $\mathrm{Ce}$ \\
\hline D1 & 0.07 & 0.36 & 0.06 \\
\hline O1 & 0.05 & 0.31 & 0.03 \\
\hline W1 & 0.07 & 0.30 & 0.04 \\
\hline D2 & & 0.09 & 0.05 \\
\hline O2 & & 0.05 & 0.02 \\
\hline W2 & 0.08 & 0.03 \\
\hline D3 & 0.07 & 0.27 & 0.04 \\
\hline O3 & & 0.06 & 0.03 \\
\hline W3 & 0.05 & 0.26 & 0.05 \\
\hline
\end{tabular}




\subsection{Ensaio Triaxial Anisotrópico não Drenado (CAU)}

A presente investigação utilizada para determinar a relação tensão-deformação foi realizada por meio de ensaios triaxiais, onde amostras de solo foram submetidas a adensamento anisotrópico com diferentes níveis de tensão, cisalhadas de forma não drenada sob deformação controlada. A relação entre a tensão horizontal e vertical usada durante 0 adensamento foi de 0.7. A velocidade de carregamento durante o cisalhamento foi de $0.03 \% / \mathrm{min}$.

\subsubsection{O equipamento utilizado nos ensaios triaxiais}

O equipamento utilizado foi uma prensa do tipo Bishop \& Wesley, que permite tanto controle de tensões como de deformações. O software de controle do ensaio foi desenvolvido pela Universidade de Durham. A Figura 8-6 apresenta o esquema da prensa triaxial utilizada na execução dos ensaios. Observa-se a indicação dos respectivos canais de leitura de cada grandeza. $\mathrm{O}$ canal $1(\mathrm{CH} 1)$ faz a leitura da célula de carga que aplica o carregamento vertical. O canal 2 (CH2) monitora o deslocamento do corpo de prova, externamente. O canal 3 $(\mathrm{CH} 3)$ monitora a pressão confinante aplicada. $\mathrm{O}$ canal $4(\mathrm{CH} 4)$ faz a leitura da contrapressão (back pressure), aplicada no topo do corpo de prova enquanto 0 canal $5(\mathrm{CH} 5)$ monitora a pressão interna do corpo de prova, podendo também ser usada para aplicar a contrapressão. A medição da variação de volume durante 0 adensamento foi feita por meio de medidor de variação de volume automático (não indicado na figura, canal $\mathrm{CH} 7$ ). Por meio da entrada correspondente ao canal $6(\mathrm{CH} 6)$ está conectada a bomba de pressão (CRSP Controlled rate strain pump). Esta bomba permite a realização dos ensaios sob deformação controlada. 


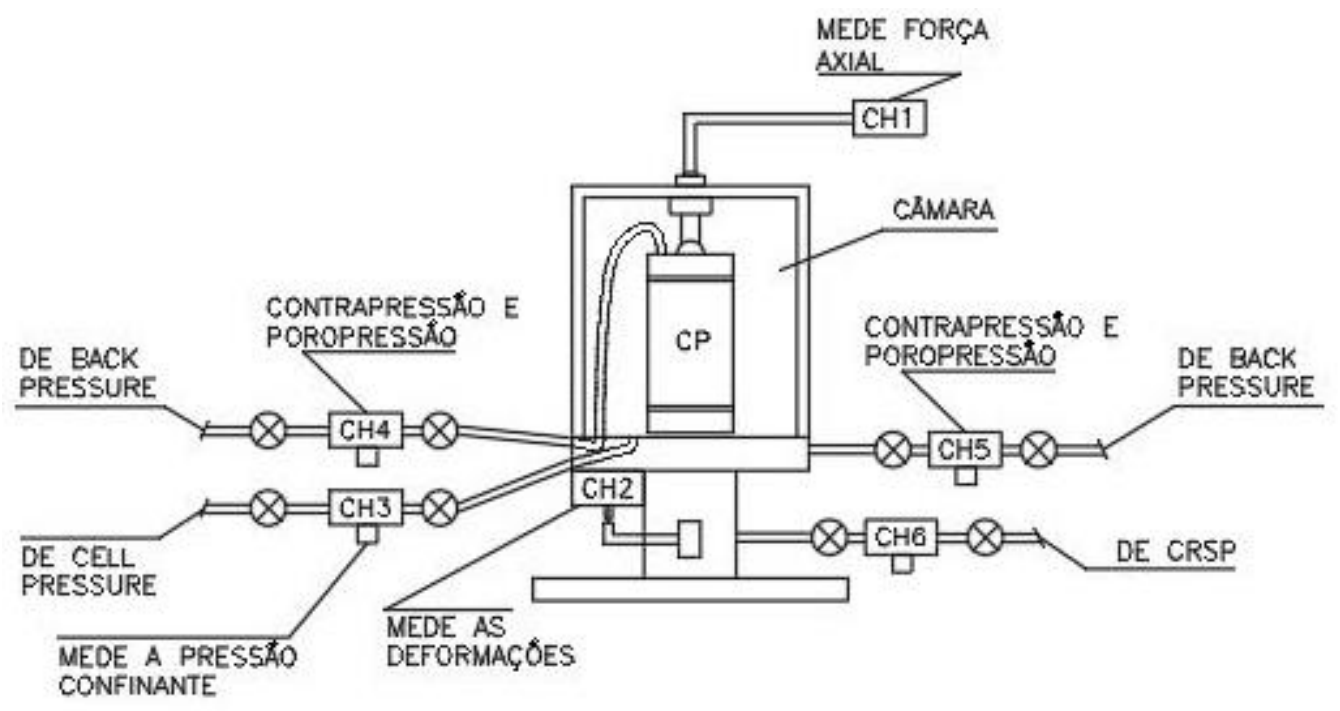

Figura 8-5 - Esquema da prensa Bishop \& Wesley (1975) utilizada na execução dos ensaios não drenados.

A Figura 8-6 apresenta o diagrama de controle de pressões. As pressões são aplicadas por meio de um compressor que manda as pressões para duas caixas de controle que ajustam a pressão conforme estabelecido pelo operador no software. As pressões são encaminhadas para cada entrada, indicada na figura como os canais correspondentes.

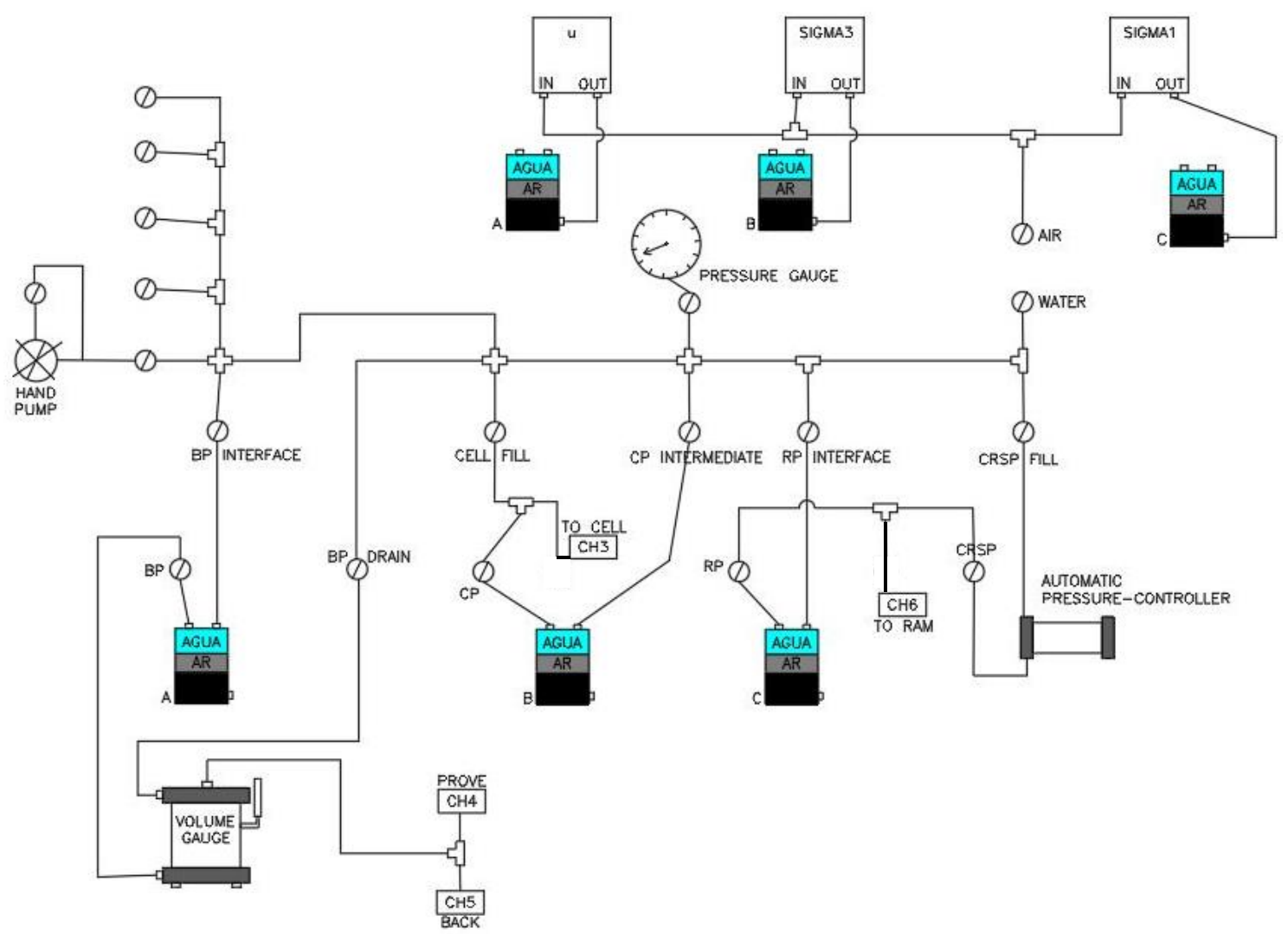

Figura 8-6 - Esquema de funcionamento do equipamento triaxial utilizado para realização dos ensaios. 


\section{MÉTODO PARA EXECUÇÃO DO ENSAIO TRIAXIAL}

\subsection{Moldagem dos corpos de prova}

O material utilizado na moldagem dos corpos de prova foi aquele passado na peneira \#4 (4.75mm), o mesmo utilizado nos ensaios de compactação. Para realização do ensaio triaxial o corpo de prova foi moldado com as seguintes dimensões: $38 \mathrm{~mm}$ de diâmetro e $80 \mathrm{~mm}$ altura.

No começo da investigação, tentou-se moldar os corpos de prova do ensaio triaxial, a partir do corpo de prova compactado no cilindro Proctor, porém o corpo de prova talhado apresentava-se muito frágil e quebrava com facilidade durante a moldagem. Por este motivo, preferiu-se adotar a moldagem estática para os corpos de prova do ensaio triaxial. Para isto utilizou-se um molde cilíndrico tripartido.

Cada corpo de prova foi compactado estaticamente com ajuda de uma prensa. A massa necessária para moldar um corpo de prova foi calculada a partir do volume do molde e densidade seca correspondente ao teor de umidade prédeterminado (Tabela 8-1). Lembrando que os pontos de estudo foram previamente definidos a partir da curva de compactação de cada amostra (BMir01, B-Mir02 e B-Mir03).

Calculada a massa total, esta foi dividida em cinco partes, já que para moldar o corpo de prova foram adotadas cinco camadas. Cada camada depositada no molde tripartido foi prensada, chegando à altura desejada com ajuda de um gabarito, retirado o gabarito escarificou-se a superfície da camada para o recebimento da próxima, este processo foi repetido em todas as camadas.

Finalizado a moldagem, o corpo de prova é retirado do interior do molde cilíndrico tripartido, o qual foi previamente untado com vaselina para facilitar a desmoldagem do corpo de prova. Houve dificuldade na desmoldagem dos corpos de prova do ponto "W2-20\% de umidade" os quais quebraram repetidas vezes. Desmoldado o corpo de prova, determinou-se a massa seu diâmetro e altura.

Na Figura 9-1 podem ser visualizadas as ferramentas utilizadas na moldagem dos corpos de prova. 

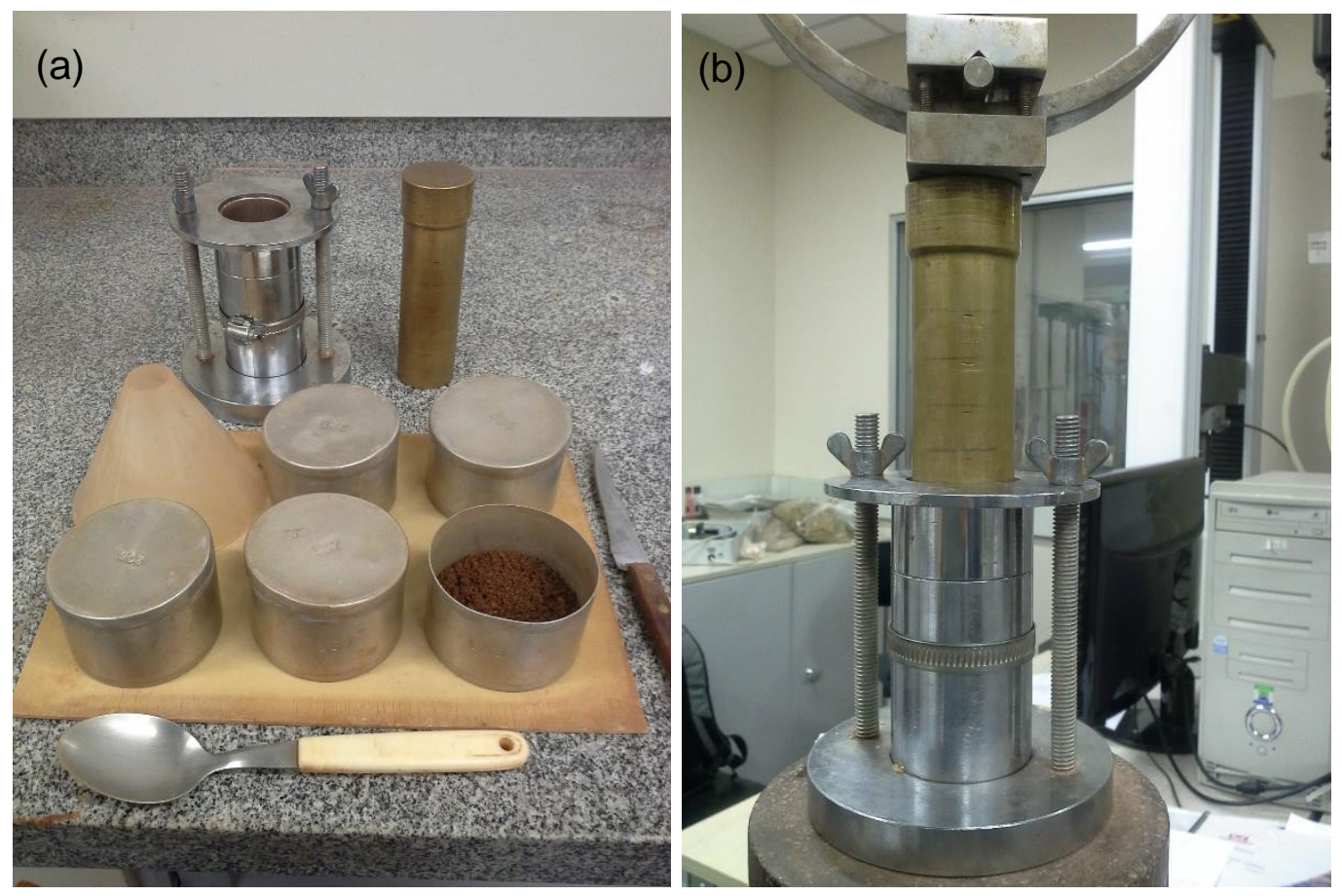

Figura 9-1 - Ferramentas para a moldagem do corpo de prova. (a) Molde cilíndrico tripartido. (b) Prensa, molde e gabarito para moldagem estática do corpo de prova.

\subsection{Montagem na câmara triaxial}

Uma vez moldado o corpo de prova, se procede a sua montagem no interior da câmara triaxial, aonde foi seguida a seguinte rotina:

- Inicialmente deve ser circulada água nas conexões do sistema denominado "Back pressure" (contrapressão) isto com a finalidade de retirar o ar do interior das conexões de drenagem de topo e base que estarão em contato com o corpo de prova.

- No pedestal da base da câmara triaxial colocar na sequência: Uma pedra porosa saturada, papel filtro, corpo de prova, papel filtro e pedra porosa saturada. As pedras porosas deverão ter sido previamente deaeradas numa bomba de vácuo. O papel filtro evita que material fino seja levado por percolação para o interior das conexões de drenagem.

- Duas membranas são colocadas para proteger o corpo de prova, na parte inferior da base do sistema é colocado um anel de borracha (o-ring) para vedação. O cabeçote é colocado no topo do C.P. sobre a pedra porosa saturada, a válvula desta conexão fica aberta permitindo a circulação de água, porém sendo evitado o excesso de água isto com a finalidade de evitar o ar no interior do conjunto montado. A manipulação deve ser de 
forma extremamente cuidadosa de modo a evitar perturbação no corpo de prova. Finalmente mais um o-ring é colocado no topo do conjunto para isolar o C.P.

- A câmara triaxial é colocada devagar tomando cuidado de modo a não bater no corpo de prova; também deve ser verificado que o pistão de medição de força axial esteja elevado para não bater no corpo de prova. Selada a câmara com auxílio dos tirantes, esta é enchida com água a partir da conexão do sistema denominado "Cell-Fill". A purga de ar localizada no topo da câmera triaxial deve ficar aberta até começar a emergir água. Fechada a válvula de água e a purga, a amostra está pronta para iniciar o estágio de saturação.

A Figura 9-2 apresenta o corpo de prova montado sobre o pedestal da câmara triaxial.

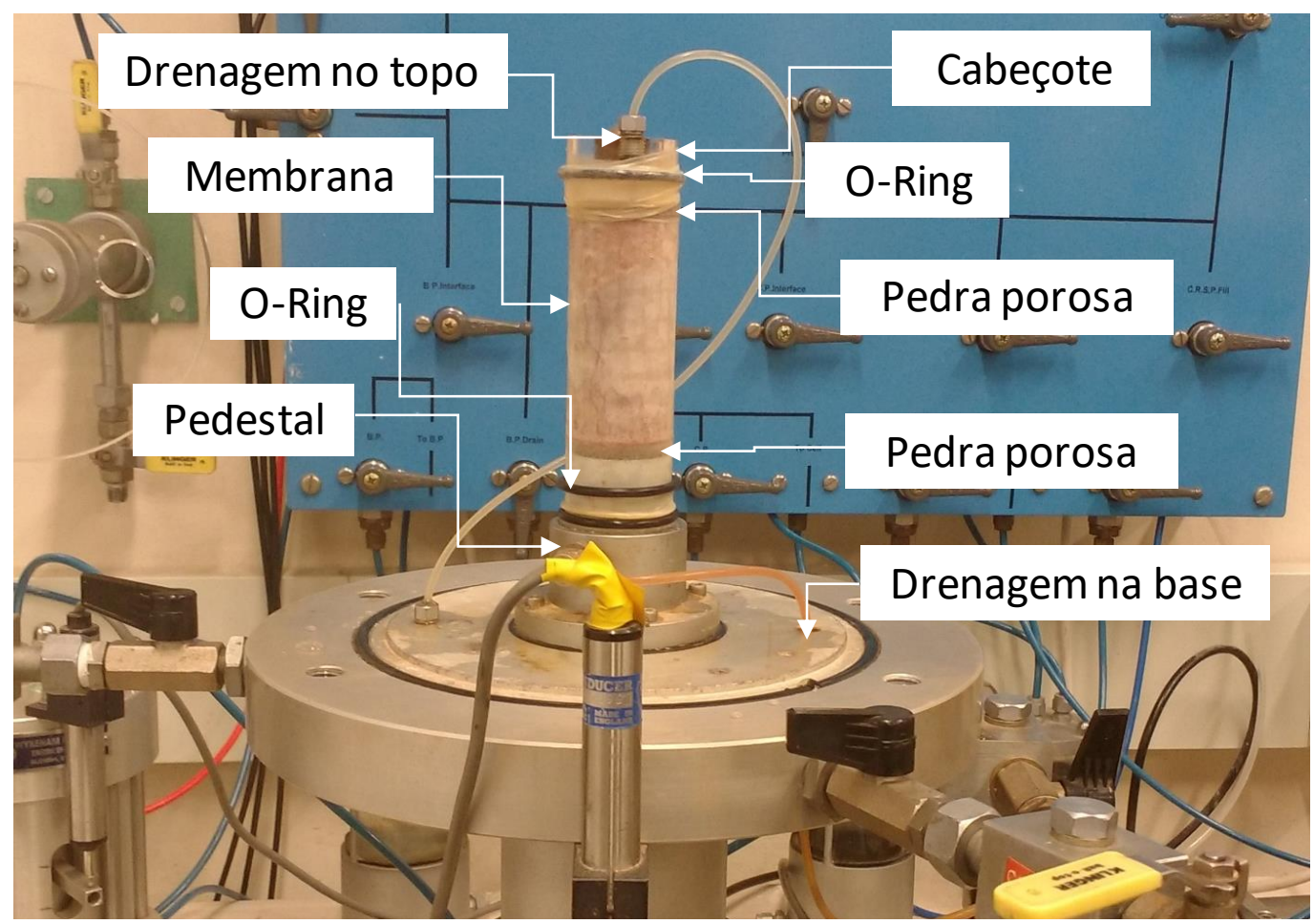

Figura 9-2 -Corpo de prova montado na base da câmara triaxial.

Na Figura 8-3 estão apresentadas imagens da sequência de montagem e ensaio dos corpos de prova. Na Figura 8-3a tem-se o corpo de prova montado no pedestal, pronto para receber a membrana, mostrada na Figura 8-3b. Na Figura 8-2c tem-se a câmera instalada para o ensaio e na Figura 8-3d tem-se uma imagem de um dos corpos de prova rompido. 


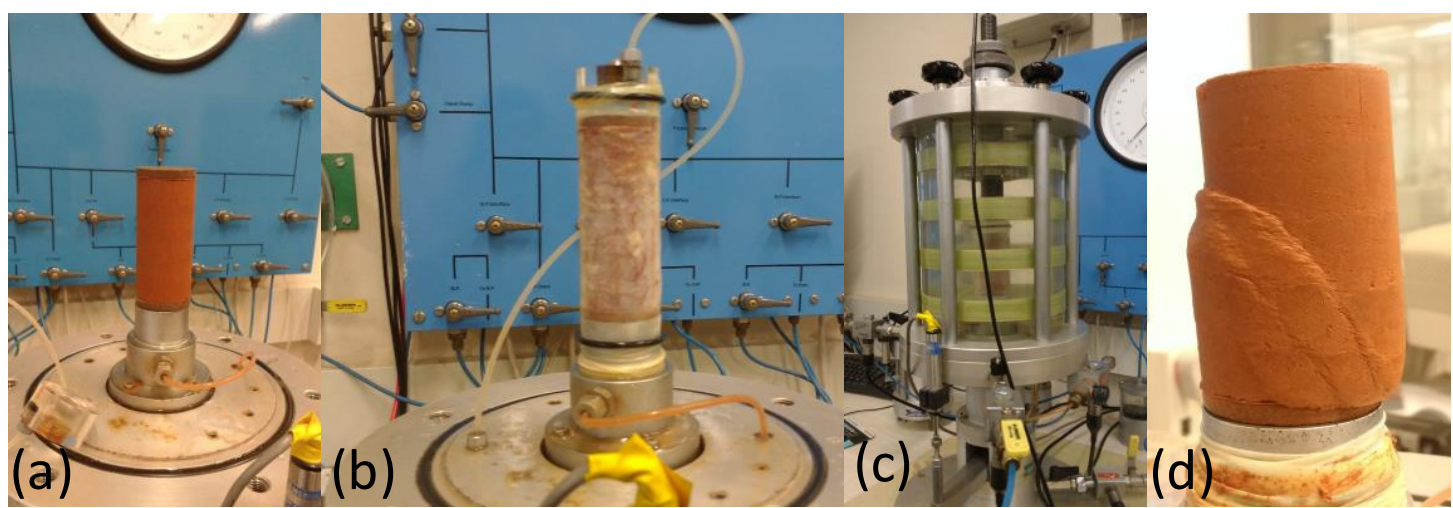

Figura 9-3 - Sequência de montagem do corpo de prova (C.P.). (a) C.P após moldagem. (b) C.P. com membrana. c) C.P. no interior da câmera triaxial d) C.P. após ruptura por deformação constante.

\subsection{Etapa de saturação}

Este processo tem o objetivo de diluir o ar no interior da amostra de solo por meio da aplicação de contrapressão no corpo de prova, preenchendo todos os vazios do corpo de prova com água. Para isto um incremento linear tanto da pressão da confinante (água na câmera) quanto da pressão dos poros d'água no corpo de prova deve ser mantido, com uma tensão efetiva constante durante todo o processo de saturação, o valor da tensão efetiva foi fixado em $10 \mathrm{kPa}$. A norma internacional ASTM D4767-11 sugere iniciar o processo com pressão confinante de no máximo $35 \mathrm{kPa}$. No ensaio a pressão confinante inicial varia entre $10 \mathrm{kPa}$ e $20 \mathrm{kPa}$. A pressão aplicada aos poros da água no interior do corpo de prova se mantém com $10 \mathrm{kPa}$ de diferença da pressão confinante. As válvulas tanto da câmera triaxial (pressão confinante) quanto do corpo de prova (pressão dos poros d'água) devem ficar abertas durante todo o processo de saturação.

O carregamento da pressão dos poros da água é automático sendo fixado 60 $\mathrm{kPa} /$ hora até atingir $490 \mathrm{kPa}$, lembrando que durante todo o processo a pressão efetiva se mantém constante $(10 \mathrm{kPa})$ a pressão confinante final será $500 \mathrm{kPa}$. Atingidos estes valores procedesse à verificação do grau de saturação por meio da medicação do "Parâmetro B de Skempton" (equação 01), para isto as válvulas de drenagem do corpo de prova devem ser fechadas, enquanto realiza-se um incremento de $50 \mathrm{kPa}$ na pressão confinante, finalizado o incremento as válvulas são abertas novamente e anota-se o novo valor da pressão no interior do corpo prova. 
$B=\frac{\Delta u}{\Delta \sigma_{3}}=\frac{u_{\text {final }}-u_{\text {inicial }}}{\sigma_{3 \text { final }}-\sigma_{3 \text { inicial }}}$

Aonde:

- $\Delta \mathrm{u}$ - Variação da poropressão quando realizado o incremento da pressão confinante quando as válvulas de drenagem do corpo de prova são fechadas.

- $\Delta \sigma_{3}$ - Variação da pressão confinante.

Se o valor obtido de B for igual ou maior que 95, o corpo de prova está pronto para ser adensado.

Antes de iniciar o processo de adensamento, deverá ser realizado um descarregamento de pressões sempre se mantendo a confinante constante com $10 \mathrm{kPa}$. O valor da pressão d'agua no interior do corpo de prova deve atingir 100 $\mathrm{kPa}$. Este processo é realizado principalmente devido às condições do equipamento o qual não pode atingir grandes pressões, as quais poderiam ser atingidas uma vez que o processo de saturação atinge $550 \mathrm{kPa}$ de confinante, por este motivo as pressões são diminuídas.

Tendo em vista que o sistema de aplicação de pressão não permite a continuação do ensaio a partir de uma confinante de $500 \mathrm{kPa}$ foi necessário o descarregamento, sempre sob tensão efetiva de $10 \mathrm{kPa}$. $\mathrm{O}$ descarregamento é feito até a poropressão de água atingir $100 \mathrm{kPa}$.

\subsection{Etapa de adensamento}

O processo de adensamento é realizado com o objetivo de aplicar diferentes valores de tensão efetiva antes do cisalhamento. Para permitir uma melhor medição dos módulos de deformabilidade durante o processo de cisalhamento adotou-se o procedimento de adensamento anisotrópico. Utilizou-se uma relação entre a tensão confinante e a tensão vertical de $0.7(\mathrm{~K}=0.7)$.

O controle do carregamento é feito automaticamente pelo software. $O$ procedimento inicial de ajuste é feito manualmente de modo a evitar perturbações no corpo de prova. Para dar início ao estágio de adensamento a contra pressão é mantida em $100 \mathrm{kPa}$ durante todo o adensamento. Foram estabelecidas as pressões confinantes de $50 \mathrm{kPa}, 100 \mathrm{kPa}$ e $200 \mathrm{kPa}$. Cada corpo 
de prova foi então submetido a um dos valores de tensão confinante, seguindo uma trajetória anisotrópica.

O processo de adensamento é realizado com o objetivo de que a amostra consiga uma condição de equilíbrio na condição drenada atingindo uma tensão efetiva necessária para iniciar a fase de cisalhamento. Durante este processo há deformação do corpo de prova, esta taxa de deformação deve ser levada em conta quando do início do cisalhamento. Para simular melhor as condições de campo, se assumiu um comportamento anisotrópico $\operatorname{com~} \mathrm{K}=0,7$, que é a relação entre tensão confinante e a tensão axial.

Para iniciar este processo o pistão que leitura o carregamento axial deve entrar em contato com o topo do corpo de prova de modo a salvar também as deformações. Este procedimento deve ser realizado de forma cuidadosa de modo a não alterar o estado do corpo de prova. Para dar início ao estágio a pressão dos poros d'água deve ter o valor de $100 \mathrm{kPa}$ o qual deve se manter em equilíbrio até o final do adensamento, a pressão confinante e a pressão axial devem partir do mesmo valor que é aproximadamente $110 \mathrm{kPa}$, porém o incremento de pressões tanto confinante quanto vertical deve guardar uma relação de 0,7 . Uma vez atingida a pressão confinante necessária para o início do cisalhamento o estágio e finalizado. Neste estudo as tensões confinantes são: $50 \mathrm{kPa}, 100 \mathrm{kPa}$ e $200 \mathrm{kPa}$.

Neste estágio não pode haver variações significativas do volume do corpo de prova para isto a válvula de drenagem da base do corpo de prova se mantém aberta e também o equilíbrio da pressão do corpo de prova de mantém constante.

\subsection{Etapa de cisalhamento}

Durante a fase de cisalhamento a pressão confinante se mantem constante enquanto é aplicada uma taxa de deformação constante, no estudo o valor desta taxa é de 0,03\%/min até atingir uma deformação total do corpo de prova de 15\%. A drenagem do corpo de prova é impedida por meio do fechamento das válvulas. Com os valores obtidos nesta fase consegue-se traçar a curva de tensão deformação. 
Mantendo constante a tensão confinante total, inicia-se a fase de cisalhamento sem permitir a drenagem do corpo de prova. O ensaio foi realizado sob deformação controlada utilizando-se uma velocidade de 0,03\%/min.

\section{RESULTADOS E DISCUSSÕES DOS ENSAIOS TRIAXIAIS}

A seguir serão apresentados analisados e discutidos os resultados dos ensaios triaxias tipo CAU (não drenados e adensados anisotrópicamente $-K=0.7$ ), realizados nas amostras de rejeito de mineração de bauxita compactados estaticamente sob diferentes condições de compactação. Serão apresentados os comportamentos tensão-deformação, assim como a variação de poropressão durante o cisalhamento. $O$ critério de ruptura utilizado na maioria dos ensaios foi o do pico da curva tensão normalizada em função da deformação axial.

Com a análise das trajetórias de tensões efetivas para a condição de cisalhamento não drenado com deformação constante $(\varepsilon=0,03 \% / \mathrm{min})$, foi determinada a envoltória de tensões efetivas e assim foram obtidos os parâmetros de resistência: Coesão efetiva e ângulo de atrito.

O parâmetro de elasticidade: Modulo de Young (E) também foi calculado para cada ensaio realizado.

10.1 Características iniciais dos corpos de prova

A Tabela 10-1 apresenta as informações sobre cada corpo de prova ensaiado e as condições de ensaio. Desta forma tem-se a nomenclatura do C.P, a tensão confinante utilizada seguida do teor de umidade de compactação, grau de saturação inicial, índice de vazios e densidade seca iniciais. A última coluna apresenta o grau de compactação atingido em cada C.P.

Foram realizados 23 ensaios triaxiais do tipo CAU aonde três corpos de prova com diferentes níveis de tensão confinada efetiva $(50 \mathrm{kPa} ; 100 \mathrm{kPa} ; 200 \mathrm{kPa})$ foram ensaiados para determinar a envoltória de ruptura de cada ponto escolhido.

Em duas condições foram ensaiados dois corpos de prova. No ponto D2 (ramo seco) e no ponto W2 (ramo úmido), ambos para a amostra B-Mir02: Em ambos os casos a confinante repetida foi de $200 \mathrm{kPa}$. A repetição do D2 foi feita por conta de dúvidas na medição da poro-pressão após a ruptura. A repetição W2 
foi realizada por conta do menor número de dados adquiridos. Salienta-se que o primeiro ensaio D2 foi descartado da análise (embora seja apresentado adiante). Os ensaios W2 com a mesma confinante se mostraram coerentes.

No caso da amostra B-Mir03, somente foram executados os ensaios para o ponto no ramo seco "D3" até a data da entrega desta dissertação.

A Tabela 10-1 apresenta as características iniciais dos corpos de prova após moldagem, aonde temos:

- $\sigma_{3}^{\prime}-$ Tensão confinante efetiva;

- $w_{i}-$ Teor de umidade inicial;

- $S_{i}-$ Grau de saturação

- $e_{i}$ - Indice de vazios inicial;

- $\rho_{d}$ - Densidade seca

- GC - Grau de compactação. 


\begin{tabular}{|c|c|c|c|c|c|c|}
\hline C.P. & $\begin{array}{c}\sigma_{3}{ }^{\prime} \\
(\mathrm{kPa})\end{array}$ & $\begin{array}{l}\mathbf{w}_{\mathbf{i}} \\
(\%)\end{array}$ & $\begin{array}{c}S_{i} \\
(\%)\end{array}$ & $\mathbf{e}_{\mathbf{i}}$ & $\begin{array}{c}\rho_{d} \\
\left(g / \mathrm{cm}^{3}\right)\end{array}$ & $\begin{array}{l}\text { GC } \\
(\%)\end{array}$ \\
\hline D1-50 & 50 & 17.8 & 53.89 & 0.90 & 1.43 & 92 \\
\hline D1-100 & 100 & 18.35 & 53.94 & 0.92 & 1.41 & 91 \\
\hline D1-200 & 200 & 18.3 & 57.07 & 0.87 & 1.45 & 93 \\
\hline $01-50$ & 50 & 23.15 & 78.94 & 0.79 & 1.51 & 97 \\
\hline $01-100$ & 100 & 23.4 & 81.00 & 0.78 & 1.52 & 98 \\
\hline $01-200$ & 200 & 24.15 & 86.14 & 0.76 & 1.54 & 99 \\
\hline W1-50 & 50 & 30.6 & 91.28 & 0.91 & 1.42 & 91 \\
\hline W1-100 & 100 & 30.15 & 91.28 & 0.90 & 1.43 & 92 \\
\hline W1-200 & 200 & 29.8 & 92.94 & 0.87 & 1.45 & 80 \\
\hline D2-50 & 50 & 15.85 & 71.09 & 0.62 & 1.72 & 95 \\
\hline D2-100 & 100 & 15.55 & 70.81 & 0.61 & 1.73 & 96 \\
\hline D2-200-A & 200 & 15.9 & 72.40 & 0.61 & 1.73 & 96 \\
\hline D2-200-B & 200 & 15.85 & 68.97 & 0.64 & 1.70 & 94 \\
\hline O2-50 & 50 & 17.3 & 86.40 & 0.56 & 1.79 & 99 \\
\hline O2-100 & 100 & 17.45 & 84.48 & 0.58 & 1.77 & 98 \\
\hline O2-200 & 200 & 17.05 & 86.49 & 0.55 & 1.80 & 100 \\
\hline W2-50 & 50 & 20 & 89.70 & 0.62 & 1.72 & 95 \\
\hline W2-100 & 100 & 19.9 & 90.61 & 0.61 & 1.73 & 96 \\
\hline W2-200-A & 200 & 19.85 & 90.39 & 0.61 & 1.73 & 96 \\
\hline W2-200-B & 200 & 19.95 & 89.47 & 0.62 & 1.72 & 99 \\
\hline D3-50 & 50 & 21.3 & 75.61 & 0.84 & 1.62 & 96 \\
\hline D3-100 & 100 & 21.15 & 77.14 & 0.82 & 1.64 & 97 \\
\hline D3-200 & 200 & 21.4 & 75.96 & 0.84 & 1.62 & 96 \\
\hline
\end{tabular}

Obs.: Os pontos no ramo seco e no ramo úmido possuem a mesma densidade seca.

$\mathrm{Na}$ Figura 10-1 apresenta-se as condições de moldagem sobrepostas aos ensaios de compactação. 


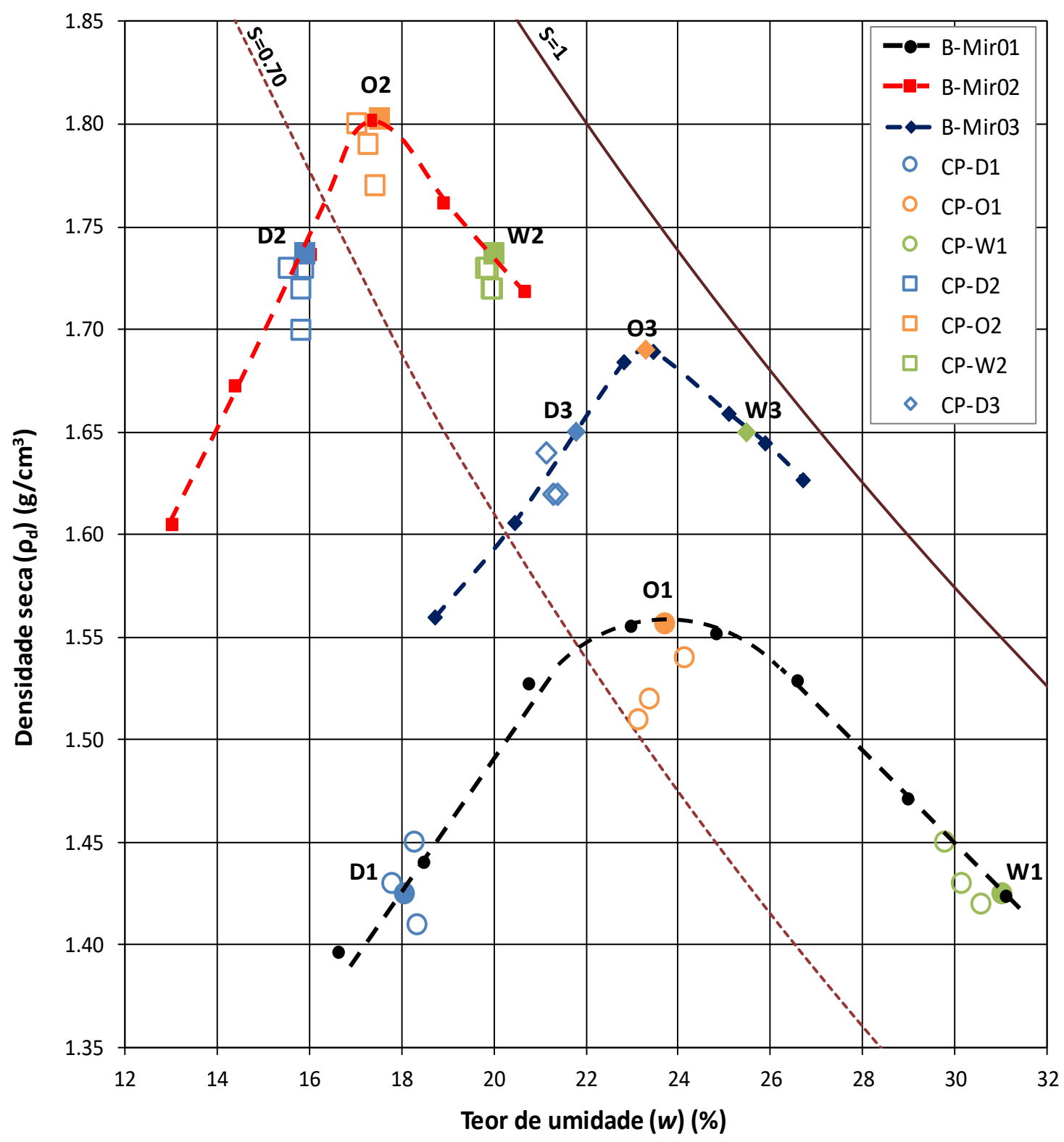

Figura 10-1 -Condição inicial dos corpos de prova moldados antes de iniciar o ensaio triaxial das amostras B-MIR01, e B-MIR02 e B-MIR03.

10.2 Parâmetro B

Na Figura 10-3 estão apresentados os valores do parâmetro B para os diversos corpos de prova, separados em função da amostra e do ponto de compactação. Observa-se que os corpos de prova preparados no ramo seco da amostra B-Mir 01 apresentaram valores de $B$ mais baixos, entre 0.70 e 0.78 . Não foi possível elevar o valor do parâmetro B aplicando-se contrapressão. No entanto, observou-se que o sistema de drenagem estava parcialmente obstruído, e que ao ser desobstruído as medições de poro pressão passaram a fornecer valores razoáveis para o parâmetro $\mathrm{B}$. Desta forma considera-se que o valor de $\mathrm{B}$ obtido nos C.P's D da amostra B- Mir01 não correspondem à realidade e seu valor deve 
ser da mesma ordem dos demais. Os valores de B para os demais C.P.'s estão suficientemente elevados para garantir a análise por meio do princípio das tensões efetivas.

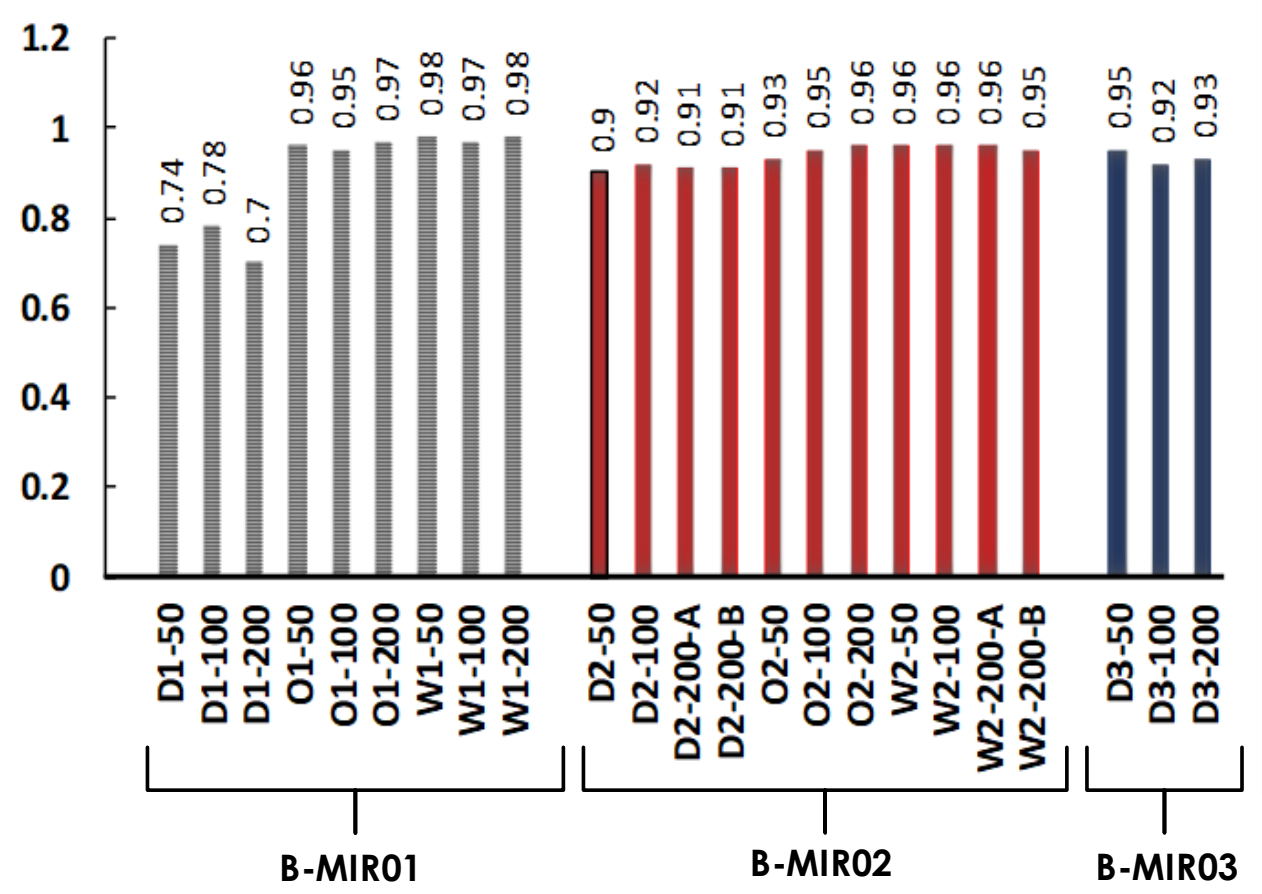

Figura 10-2 -Resultados do parâmetro B para as amostras B-Mir01, B-Mir02 e B-Mir03.

10.3 Curvas tensão desviadora-deformação axial

Foram obtidos 7 conjuntos de resultados curvas tensão-deformação, sendo três para o B-Mir01 nos pontos D1, O1 e W1, três para o B-Mir02 nos pontos D2, O2 e W2 e um para o B-Mir03 no ponto D3 (ramo seco).

Os comportamentos a serem avaliadas em função da deformação axial $\varepsilon_{a}(\%)$ são:

- Tensão desviadora - q (kPa) vs deformação axial - $\varepsilon_{a}(\%)$

- Variação da poropressão - $\Delta \mathrm{u}(\mathrm{kPa})$ vs deformação axial - $\varepsilon_{\mathrm{a}}(\%)$

- Tensão desviadora normalizada - $\frac{q}{\sigma_{3}}$ vs deformação axial - $\varepsilon_{a}(\%)$ 


\subsubsection{Amostra B-Mir01}

A Figura 10-3 apresenta os resultados dos ensaios realizados com a amostra BMir01 nos três pontos de estudo: D1 (ramo seco - figuras a, b, c), O1 (umidade ótima - figuras d, e, g) e W1(ramo úmido - figuras g,h,i).

As Figuras a, d, g, apresentam as tensões desviadoras; já nas figuras b, e, h mostram a variação de poropressões, e nas figuras c, f, i estão as tensões desviadoras normalizadas, todas estas em função da deformação axial. A etapa de cisalhamento foi paralisada em função da comprovação da tensão desviadora residual constante, atingida com uma deformação axial acima de $10 \%$

Com relação as tensões desviadoras (figuras a, d, g) observa-se que todos os corpos de prova cisalhados no ramo seco "D1" apresentaram um pico de resistência com aproximadamente $2 \%$ de deformação. Os corpos de prova do ponto "O1" e do ponto "W1" não apresentaram pico.

Os corpos de prova moldados no ponto "O1" (figura d) apresentaram maiores valores de tensão desviadora, isto por que foram moldados com maior densidade seca. Os valores máximos de tensão desviadora do ponto "O1" foram atingidos com aproximadamente $2 \%$ de deformação e estes valores são aproximadamente $40 \%$ maiores se comparados com os outros pontos de estudo. Já o ponto "W1" apresentou menores valores de tensão desviadora comparado aos corpos de prova "D1", apesar de terem sido moldados com a mesma densidade seca. 0 fato de terem sido moldados com diferentes umidades explica esta diferença no comportamento, o que deve refletir a estrutura dos corpos de prova.

Em termos da variação de poropressão (figuras b,e,h) observa-se que as máximas variações de poropressão nos três estados de confinamento se mostraram semelhantes para os C.P.'s moldados nas condições D1 e W1. A máxima variação de poropressão aconteceu para diferentes valores de deformação axial. Para os C.P.'s moldados na condição D1 a máxima poro pressão ocorreu para uma deformação de $6 \%$, enquanto para os C.P.'s moldados na condição W1 foi de $2 \%$.

$\mathrm{Na}$ condição de moldagem do ponto $\mathrm{O} 1$, os valores máximos de variação de poropressão representam aproximadamente $40 \%$ dos valores máximos dos pontos D1 e W1. Após atingido o valor máximo, se observa que há um decréscimo da variação em todas as situações de confinamento, passando a ter 
valores negativos no caso do menor estado de confinamento. Este comportamento se reflete no desenvolvimento da tensão desviadora que experimenta um aumento de resistência. O máximo valor de poropressão nestes casos aconteceu para deformações axiais de $2 \%$.

Para definição da envoltória de ruptura se utilizou o critério das curvas de tensão desviadora normalizada (figuras $\mathrm{c}, \mathrm{f}$, i). Estas curvas são obtidas a partir da divisão da tensão desviadora pela sua própria tensão confinante efetiva no mesmo instante. Nos gráficos se observa que somente os pontos "O1" e "W1" apresentaram pico para os menores estados de confinamento. Os máximos valores foram atingidos com $1 \%$ de deformação axial no caso do ponto "O1" e $4 \%$ para o ponto "W1". Já o ponto "D1" apresenta seus valores máximos com $5 \%$ de deformação para o menor estado de confinamento $(50 \mathrm{kPa})$ e de $9 \%$ aproximadamente, para as maiores.

Os maiores excessos de poropressões aconteceram aproximadamente com as mesmas deformações que geraram os máximos valores das tensões desviadoras normalizadas.

Nos gráficos também se observa que os máximos valores de tensão desviadora normalizada não necessariamente coincidem com os máximos valores de tensão desviadora, o que significa que a escolha de cada um destes critérios de ruptura gera duas envoltórias diferentes na trajetória de tensões efetivas (linha $\mathrm{K}_{\mathrm{f}}$ ). No caso desta amostra para os pontos $\mathrm{O} 1$ e W1 foi escolhido o critério das tensões normalizadas e para a amostra D1 o critério utilizado foi o da tensão desviadora já que como visto os picos ocorreram com até $2 \%$ de deformação axial.

Por tanto a partir dos resultados obtidos para a amostra B-Mir01, como esperado os corpos de prova $\mathrm{O} 1$ apresentaram maior resistência por ter a maior densidade seca, menor índice inicial de vazios e desenvolver menos excesso de poropressões durante o cisalhamento. 


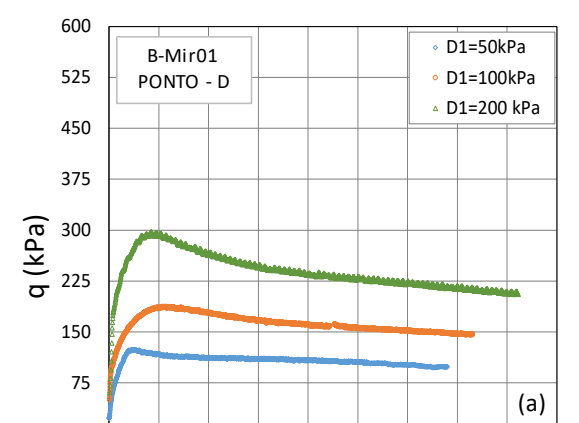

(a)
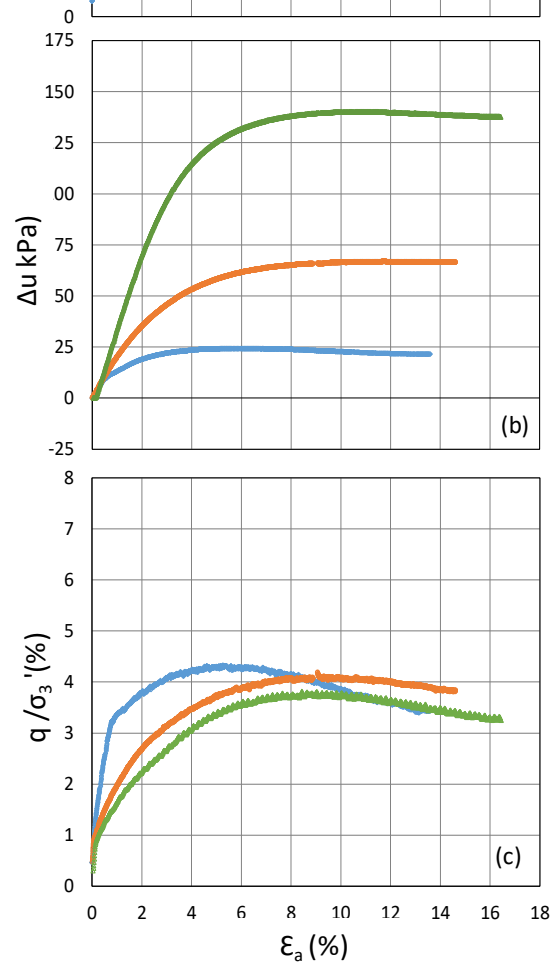
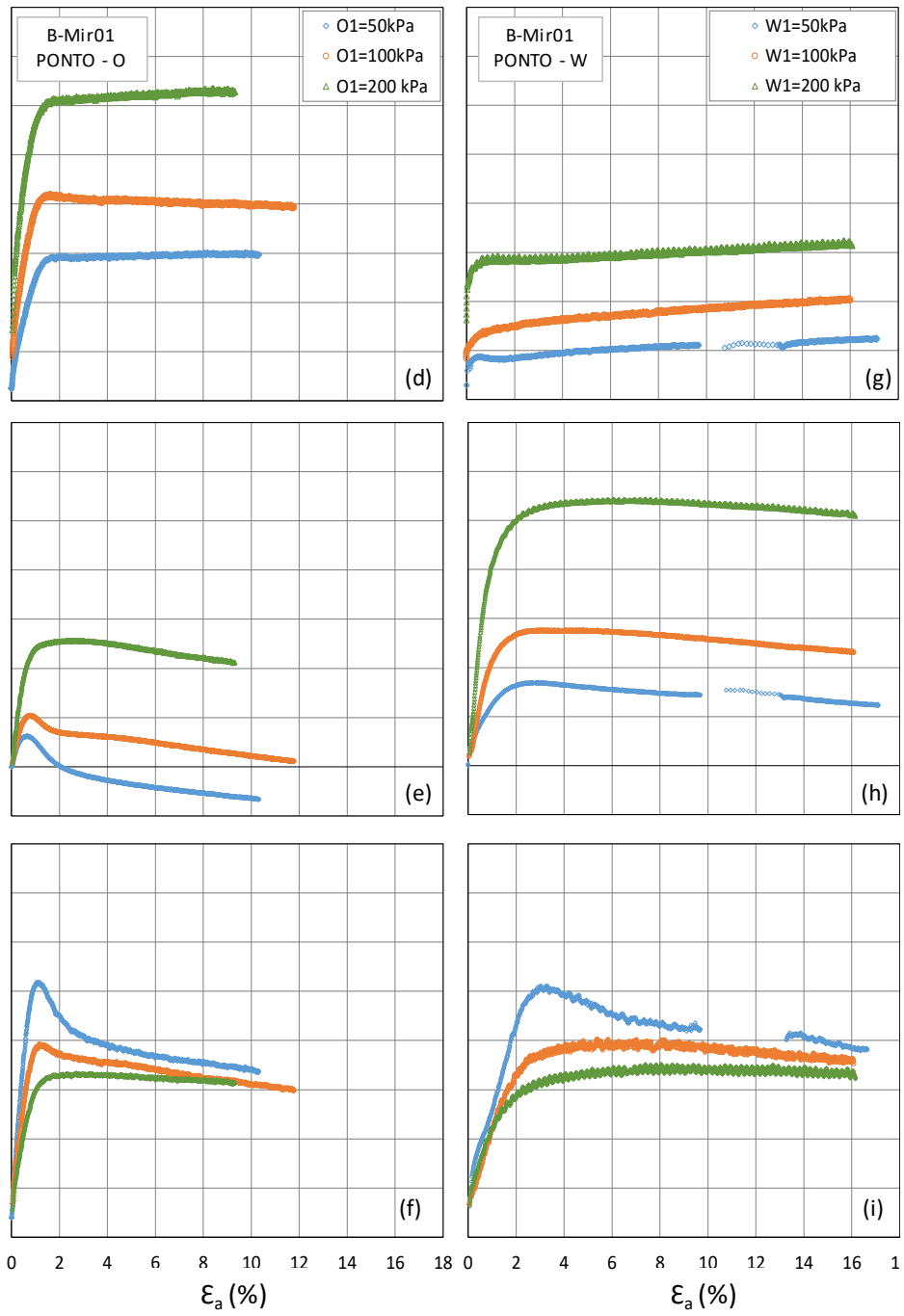

Figura 10-3 Resultados dos ensaios triaxiais para a amostra B-Mir01. Curvas tensão deformação axial: (a) Ponto D1; (b) Ponto 01; (c) Ponto W1. Excesso de poropressão deformação axial: (d) Ponto D1; (e) Ponto 01; (f) Ponto W1. Curva tensão normalizada deformação axial: (g) Ponto D1; (h) Ponto 01; (i) Ponto W1.

\subsubsection{Amostra B-Mir02}

A Figura 10-4 apresenta os resultados dos ensaios realizados com a amostra BMir02 em três pontos de estudo: D2 (ramo seco - figuras a, b, c), O2 (umidade ótima - figuras d, e, g) e W2 (ramo úmido - figuras g, h, i).

No ponto de estudo D2 e W2 como falado no item 10.1, para a condição de confinamento de $200 \mathrm{kPa}$ foram moldados dois corpos de prova, o 200-A e o 200$B$, cujos resultados são apresentados em todos os gráficos, porém os resultados do C.P D2-200-A foram descartados da análise por se ter dúvidas sobre os valores medidos de proopressão. No caso dos dois corpos de prova do ponto W2, os resultados foram considerados por apresentarem resultados coerentes entre si. 
Em todos os ensaios a etapa de cisalhamento foi paralisada em função da comprovação da tensão desviadora residual constante, atingida com uma deformação axial acima de $10 \%$.

Com relação as tensões desviadoras (figuras a, d, g) observa-se que os C.P.s do ponto D2 (figura a) apresentaram picos para as três tensões confinante. Os picos foram observado para deformações axiais de $2 \%$ para as confinantes de $50 \mathrm{kPa}$ e $100 \mathrm{kPa}$ e 4\% de deformação para a tensão de $200 \mathrm{kPa}$. Os C.P.s do ponto $\mathrm{O} 2$ apresentaram picos com aproximadamente 3\% de deformação axial. Dos C.P.s do ponto W2 apenas o ensaiado com $50 \mathrm{kPa}$ de confinante apresentou pico, observada com $2 \%$ de deformação axial. Os demais ensaios apresentam um valor máximo para $4 \%$ de deformação.

Em termos de valores de resistência máxima se observa que o ponto $\mathrm{O} 2$ apresentou valores entre $20 \%$ e $25 \%$ superiores aos valores máximos do ponto D2 para todos os estados de confinamento. Comparados os valores máximos de tensão desviadora do ponto $\mathrm{O} 2$ e ponto $\mathrm{W} 2$ tem-se que os valores de pico para $50 \mathrm{kPa}$ ficaram próximos, já para as tensões confinantes de 100 kPa e 200 kPa, houve uma diferença de $15 \%$ entre valores máximos. Os comportamentos dos corpos de prova da amostra B-Mir02 apresentaram-se semelhante, provavelmente devido à proximidade entre os teores de umidade de compactação (menor que $2 \%$ ).

Em termos da variação de poropressão (figuras b,e,h) os corpos de prova de todos os pontos (D2, O2, W2) apresentaram pico. Os picos aconteceram para valores de deformação de até $1 \%$. Após atingido o pico o excesso de poropressões começou a diminuir até apresentar variações negativas o que significa um aumento de resistência.

O critério de ruptura utilizando as curvas de tensão desviadora normalizada (figuras $\mathrm{c}, \mathrm{f}, \mathrm{i}$ ) foi utilizado para a definição da envoltória de ruptura. Nestas figuras se observa que para todos os pontos de estudo (D2, O2 e W2) foi observado picos., independentemente da tensão confinante. Os valores dos picos (normalizados) foram atingidos com até $2 \%$ de deformação axial para todas as condições de moldagem. 

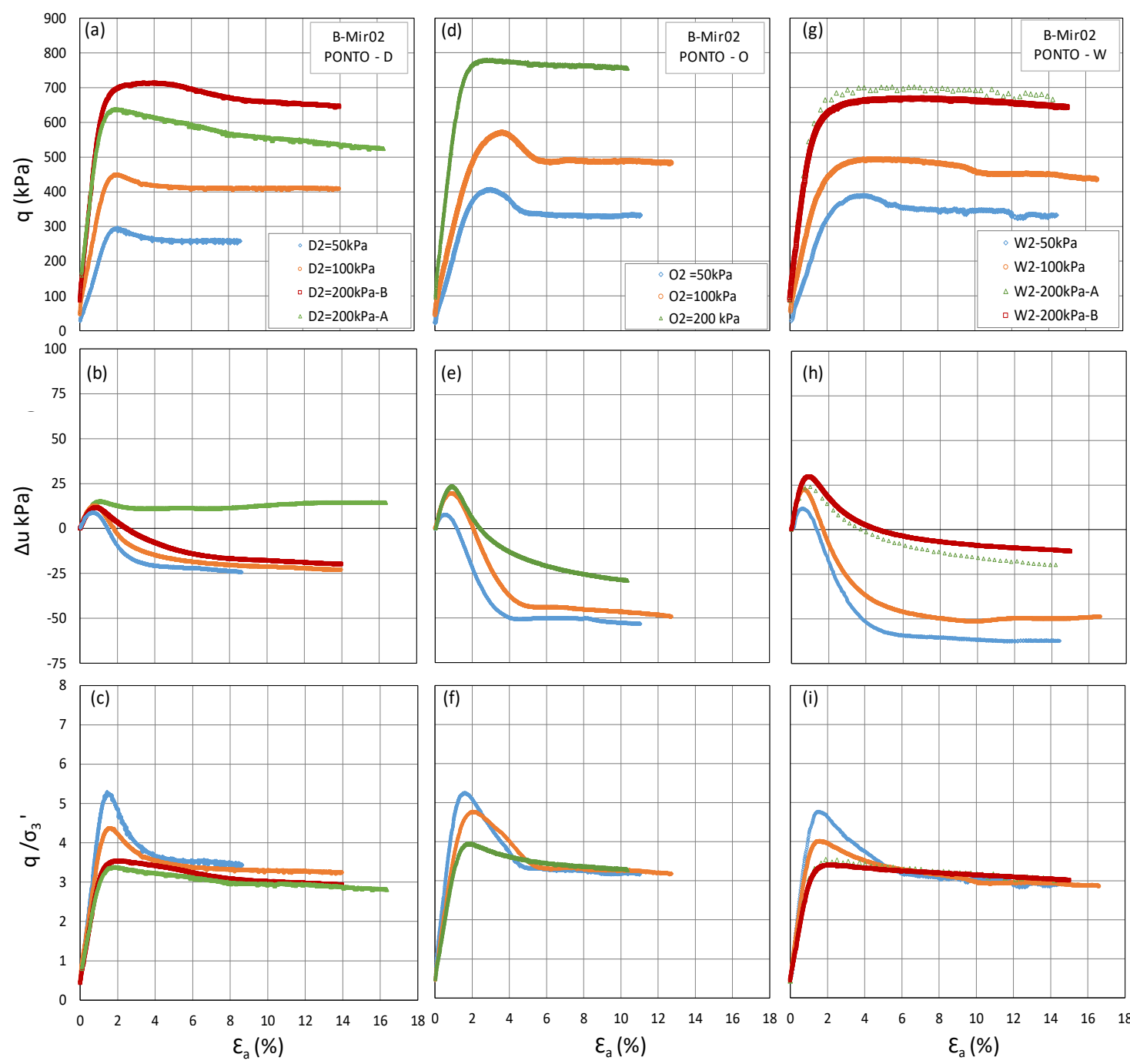

Figura 10-4 Resultados dos ensaios triaxiais para a amostra B-Mir02. Curvas tensão deformação axial: (a) Ponto D2; (b) Ponto 02; (c) Ponto W2. Excesso de poropressão deformação axial: (d) Ponto D2; (e) Ponto O2; (f) Ponto W2. Curva tensão normalizada deformação axial: (g) Ponto D2; (h) Ponto 02; (i) Ponto W2.

\subsubsection{Amostra B-Mir03}

Os resultados das curvas tensão deformação, variação de poropressão com a deformação e a tensão desviadora normalizada com a deformação, estão apresentadas nas Figura 10-5 (a,b e c). Conforme mencionado anteriormente, para a amostra B-Mir03 foram realizados ensaios triaxiais apenas no ponto de estudo D3.

A tensão desviadora apresentou picos para as três tensões de confinamento, com aproximadamente $1.5 \%$ de deformação para as tensões com $200 \mathrm{kPa}$ e 100 $\mathrm{kPa}$ e $2.5 \%$ de deformação para a tensão de $50 \mathrm{kPa}$.

Com relação ao excesso de poropressões observa-se que para as tensões de confinamento com $50 \mathrm{kPa}$ e $100 \mathrm{kPa}$ observou-se pico para 1 \% de deformação, 
após o pico o excesso foi reduzindo até atingir valores de variação negativa. Já para o C.P. submetido a $200 \mathrm{kPa}$ de confinamento, observa-se que o excesso de poropresssões não apresentou pico mantendo-se crescente até o final do ensaio, o que significa a redução da resistência após a ruptura.

A figura c traz os resultados da curva de tensão desviadora normalizada que mostra que para as tensões de confinamento menores (50 kPa e $100 \mathrm{kPa})$ temse pico, diferentemente da curva referente à tensão de $200 \mathrm{kPa}$. Os máximos valores foram atingidos com $1.5 \%$ de deformação, a partir dos quais foi determinada a envoltória de trajetória de tensões efetivas. 

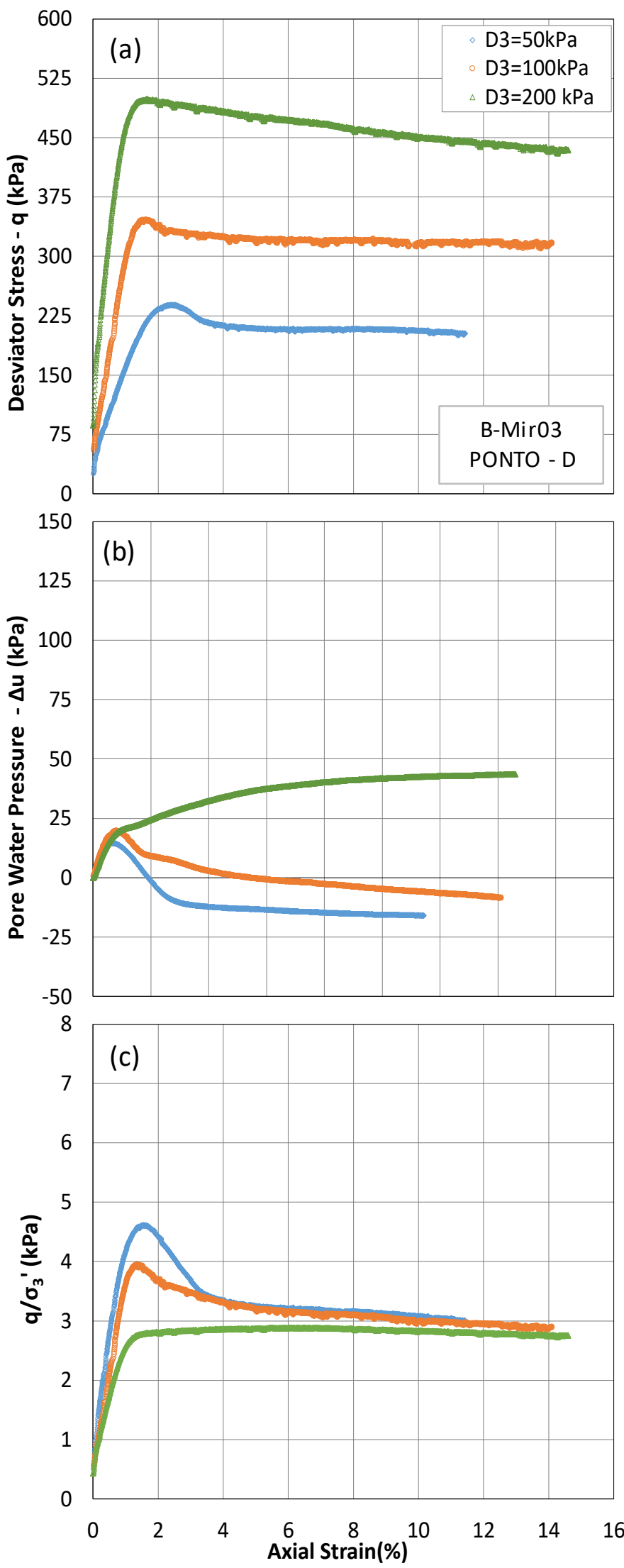

Figura 10-5 Resultados dos ensaios triaxiais para a amostra B-Mir03 no ponto D3. (a) Curva tensão-deformação axial. (b) Excesso de poropressão-deformação axial. (c) Curva tensão normalizada-deformação axial. 


\subsubsection{Compilação dos dados}

Na Tabela 9-3, estão apresentados os dados de ruptura dos diversos ensaios realizados. São apresentados: A tensão desviadora na ruptura ( $\left.q_{\max }\right)$, a deformação axial na ruptura ( $\left.\varepsilon_{a-m a x}\right)$, a variação de poropressão na ruptura ( $\left.\Delta u_{\max }\right)$, a tensão desviadora normalizada na ruptura $\left(q / \sigma_{3 f}\right)$, a deformação axial na ruptura $(\varepsilon a-f)$, a tensão desviadora pós pico $\left(q_{p p}\right)$, a deformação axial pós pico $(\varepsilon a-p)$.

Tabela 9-3 - Resumo dos resultados dos ensaios triaxiais.

\begin{tabular}{|c|c|c|c|c|c|c|c|}
\hline $\begin{array}{c}\text { Corpo de } \\
\text { prova }\end{array}$ & $\begin{array}{c}q_{\max } \\
(\mathrm{kPa})\end{array}$ & $\begin{array}{c}\mathcal{E}_{\mathrm{a}-\max } \\
(\%)\end{array}$ & $\begin{array}{l}\Delta \mathrm{u}_{\max } \\
(\mathrm{kPa})\end{array}$ & $\frac{q}{\sigma_{3}} f$ & $\begin{array}{l}\varepsilon_{a-f} \\
\%)\end{array}$ & $\begin{array}{c}\mathrm{q}_{\mathrm{pp}} \\
(\mathrm{kPa})\end{array}$ & $\begin{array}{r}\varepsilon_{a-p p} \\
(\%)\end{array}$ \\
\hline D1-50 & 126.20 & 0.753 & 11.80 & 4.30 & 5.028 & 117.0 & 1.968 \\
\hline D1-100 & 189.50 & 1.602 & 29.60 & 4.06 & 8.011 & 163.4 & 5.962 \\
\hline D1-200 & 299.70 & 1.447 & 50.58 & 3.74 & 7.807 & 244.7 & 6.037 \\
\hline $01-50$ & 213.80 & 1.445 & 5.80 & 4.46 & 1.830 & - & - \\
\hline $01-100$ & 319.40 & 1.374 & 20.90 & 3.11 & 1.513 & - & - \\
\hline $01-200$ & 466.10 & 1.606 & 60.10 & 2.26 & 1.680 & - & - \\
\hline W1-50 & 113.80 & 1.199 & 20.50 & 5.05 & 3.060 & - & - \\
\hline W1-100 & 214.40 & 0.640 & 58.90 & 3.93 & 5.430 & - & - \\
\hline W1-200 & 465.60 & 0.322 & 86.30 & 3.43 & 7.430 & & \\
\hline D2-50 & 299.70 & 1.984 & -9.80 & 5.22 & 1.390 & 261.20 & 3.951 \\
\hline D2-100 & 451.60 & 1.974 & -3.00 & 4.35 & 1.600 & 413.40 & 4.015 \\
\hline D2-200-A & 642.70 & 1.788 & 13.10 & 3.37 & 1.700 & 564.10 & 8.027 \\
\hline D2-200-B & 715.20 & 2.696 & -1.50 & 3.53 & 1.890 & 669.50 & 8.028 \\
\hline O2-50 & 408.20 & 2.889 & -34.20 & 5.24 & 1.560 & 334.30 & 5.985 \\
\hline O2-100 & 564.90 & 3.590 & -32.80 & 4.76 & 1.980 & 491.10 & 6.053 \\
\hline O2-200 & 780.30 & 2.259 & 2.40 & 3.93 & 1.850 & 773.70 & 6.010 \\
\hline W2-50 & 355.90 & 3.559 & -60.80 & 4.76 & 1.460 & - & - \\
\hline W2-100 & 491.32 & 3.988 & -37.20 & 4.00 & 1.700 & - & - \\
\hline W2-200-A & 698.4 & 3.707 & 0.20 & 3.54 & 1.910 & - & - \\
\hline W2-200-B & 660.45 & 3.957 & 2.60 & 3.39 & 2.22 & - & - \\
\hline D3-50 & 238.64 & 2.399 & & 4.61 & 1.52 & 212.10 & 4.015 \\
\hline D3-100 & 345.50 & 1.599 & & 3.94 & 1.42 & 324.50 & 4.020 \\
\hline D3-200 & 499.2 & 1.492 & & 2.82 & 2.32 & 483.76 & 3.989 \\
\hline
\end{tabular}


10.4 Trajetória de tensões efetivas

Para melhor visualização do desenvolvimento das poropressões, o método MIT de trajetória de tensões (Lambe, 1964) foi utilizado para analisar os dados obtidos para as amostras B-Mir01, B-Mir02 e B-Mir03, aonde as trajetórias, foram plotadas em termos de tensões efetivas ( $t$ versus $s '$ ).

A sequência de pontos, que formam a trajetória de tensões efetivas, representa a máxima tensão de cisalhamento para o qual o material é solicitado enquanto $o$ estado de tensões varia.

O primeiro ponto de todos os gráficos da trajetória de tensões apresentados, representa o estado inicial de tensões de cada amostra após finalização da fase de adensamento, lembrando que durante a fase de adensamento a relação $\frac{\sigma_{3^{\prime}}}{\sigma_{1^{\prime}}}$ adotada foi igual a 0.7 .

10.4.1 Amostra B-Mir01:

A trajetória de tensões efetivas obtidas para a amostra B-Mir01 estão apresentadas, na Figura 10-6 (ramo seco ponto D1), Figura 10-7 (umidade ótima - ponto 01) e Figura 10-8 (ramo úmido, ponto W1).

A envoltória de ruptura definida para o ponto D1, foi obtida a partir da escolha dos valores máximos de tensão desviadora. Na Figura 10-6 é possível observar que para o ponto D1 apenas poropressões positivas foram desenvolvidas. Ao atingir o ponto de ruptura os corpos de prova apresentaram um significativo aumento de poropressão. 


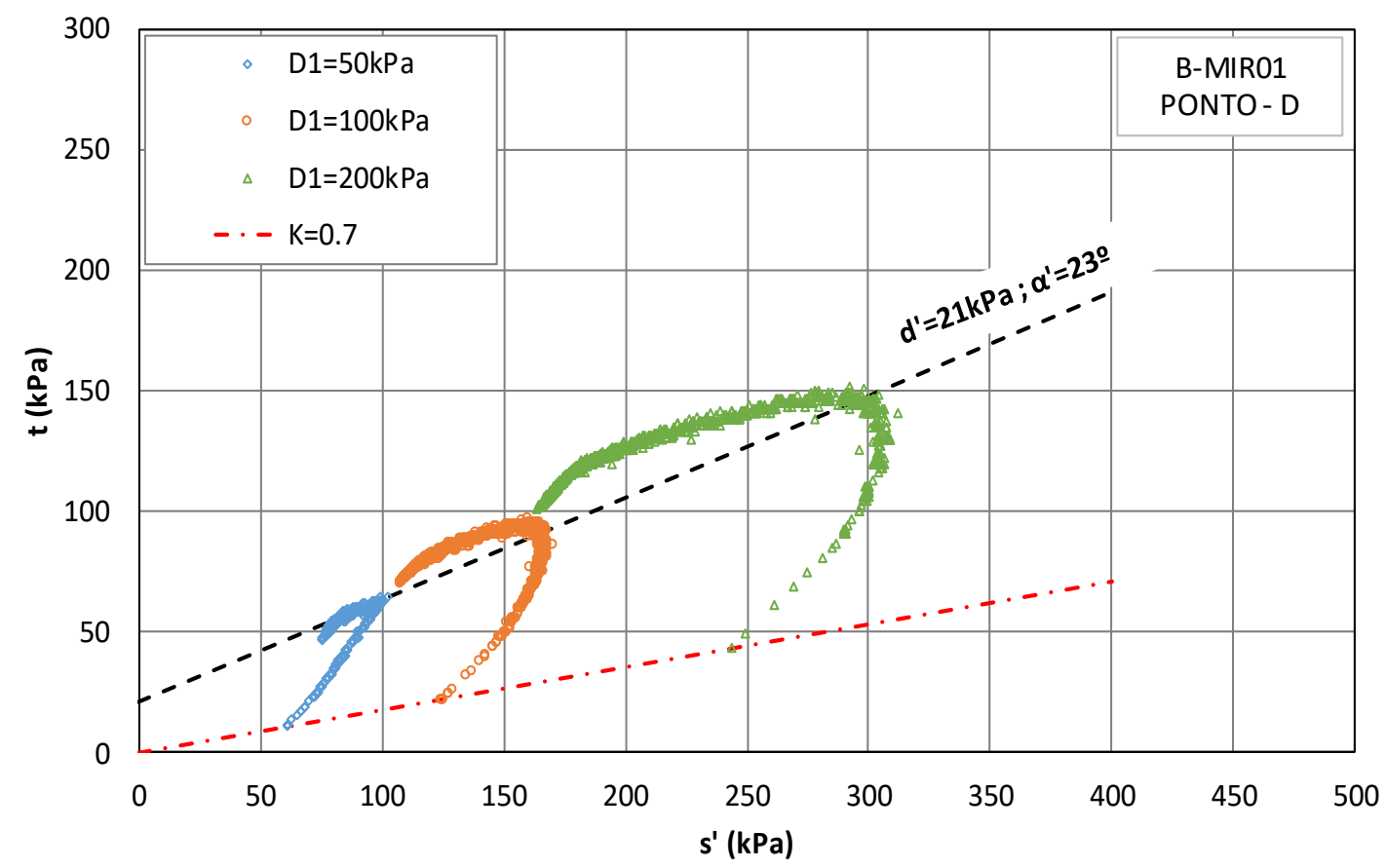

Figura 10-6 Trajetória de tensões efetivas para o ponto D1.

Os corpos de prova correspondentes ao ponto O1, moldados na umidade ótima e com máxima densidade seca, apresentam um comportamento diferente daquele do ponto D1, no ramo seco. A Figura 10-7 apresenta as trajetórias de tensões para o ponto $\mathrm{O} 1$, onde observa-se que ao se aproximar da ruptura há uma tendência de redução das poropressões, sugerindo um comportamento dilatante.

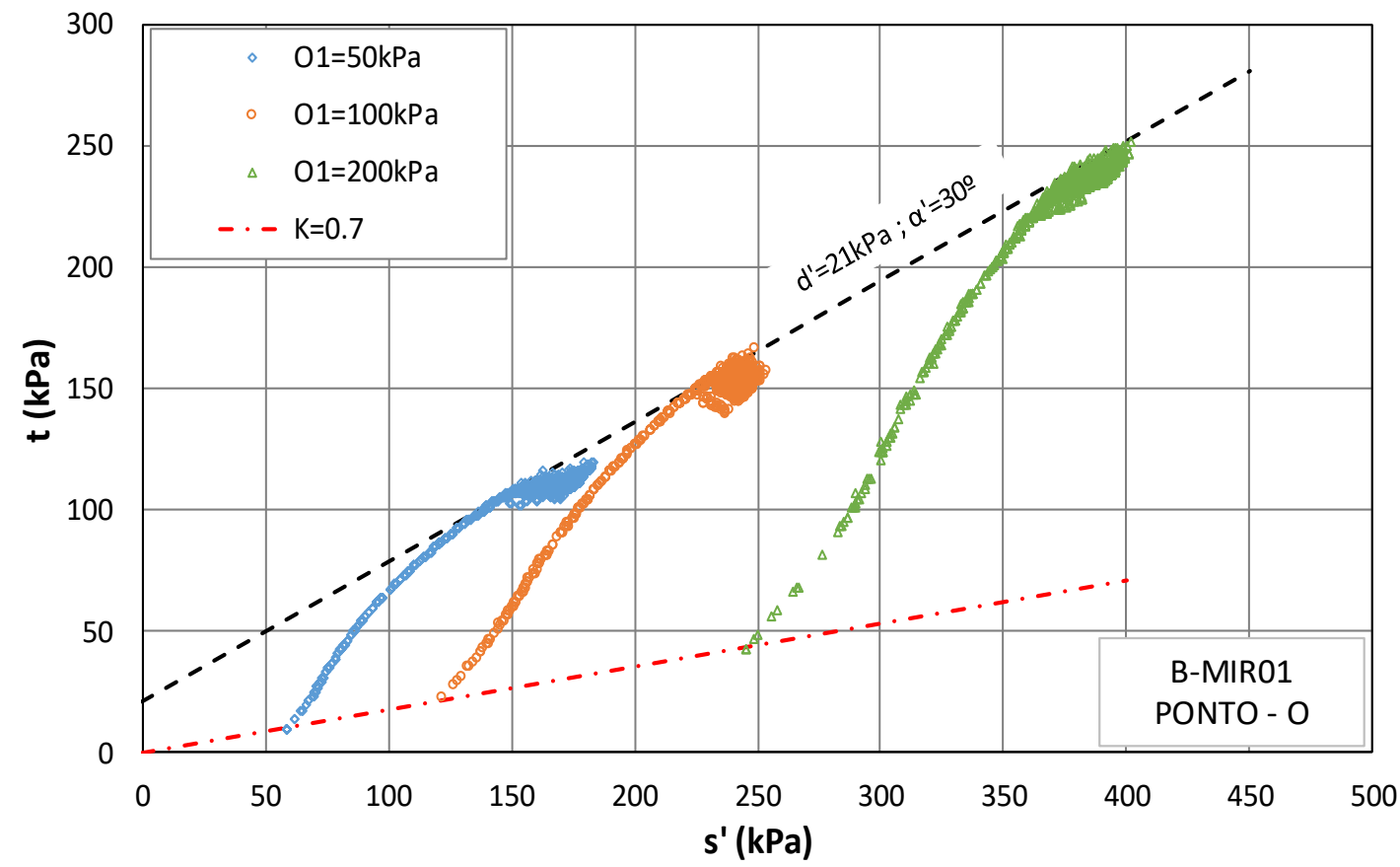

Figura 10-7 Trajetória de tensões efetivas para o ponto 01. 
$\mathrm{Na}$ trajetória de tensões efetivas para os corpos de prova $\mathrm{W} 1$ mostrados na Figura 10-8 se observa um elevado desenvolvimento de poropressões positivas antes de atingir a ruptura. Este comportamento pode indicar uma metaestabilidade conforme sugerido por Davies (2002). Assim que foi atingida a envoltória, todos os corpos de prova apresentaram uma redução da poropressão, também sugerindo um comportamento dilatante após a ruptura. Com este resultado fica claro o efeito da estrutura do material no seu comportamento.

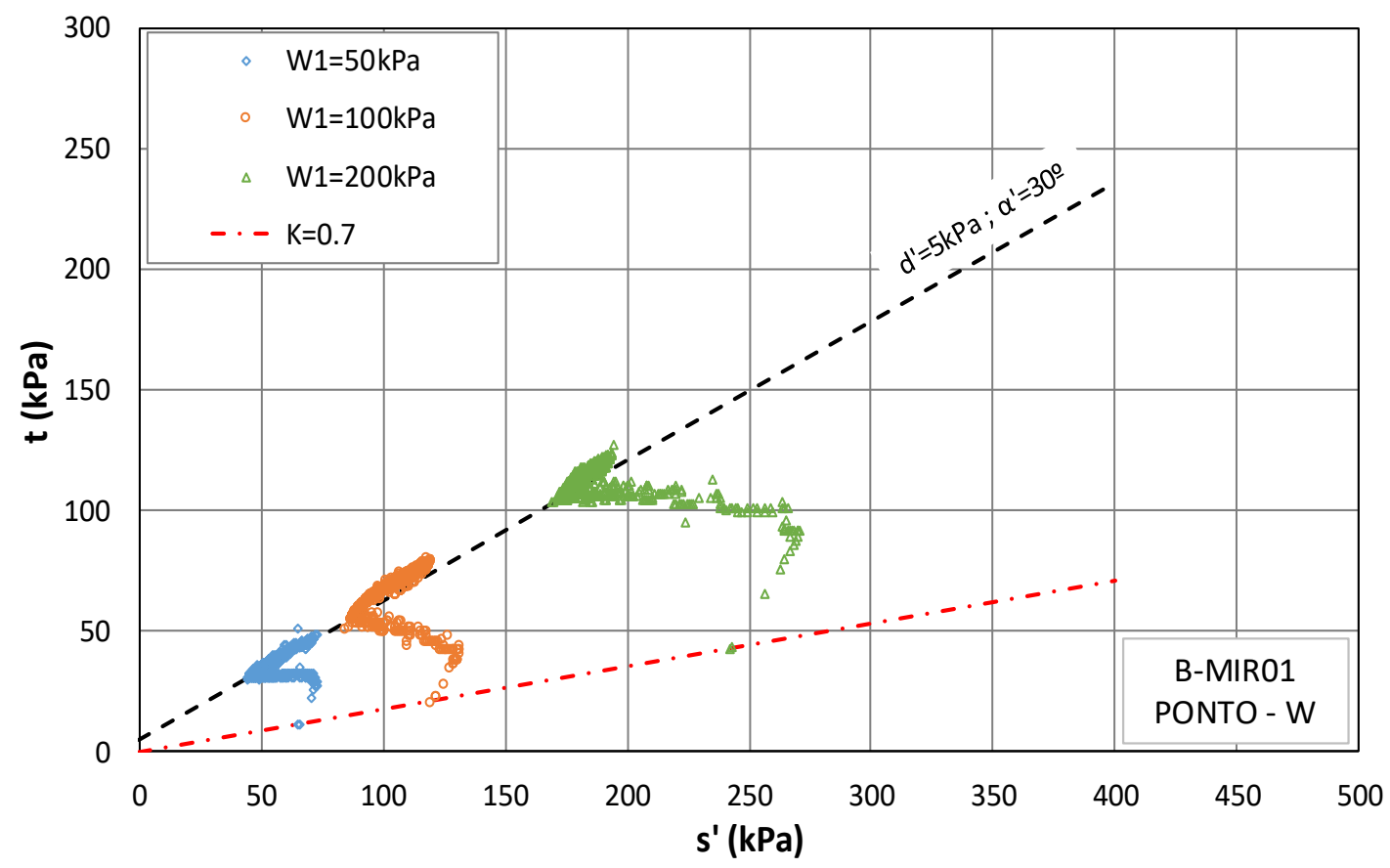

Figura 10-8 Trajetória de tensões efetivas para o ponto W1.

10.4.2 Amostra B-Mir02:

A trajetória de tensões efetivas obtidas para a amostra B-Mir02 estão apresentadas, na Figura 10-10 (ramo seco ponto D2), Figura 10-11(umidade ótima - ponto O2) e Figura 10-11 (ramo úmido, ponto W2).

A envoltória de ruptura definida para o ponto D2, foi obtida a partir da escolha dos valores máximos de tensão desviadora normalizada. Na Figura 10-10 se observa, pelo formato da trajetória, pouco desenvolvimento de poropressões positivas até a ruptura. Após atingir a ruptura observa-se redução de poropressão. O comportamento foi semelhante para todas as condições de confinamento. 


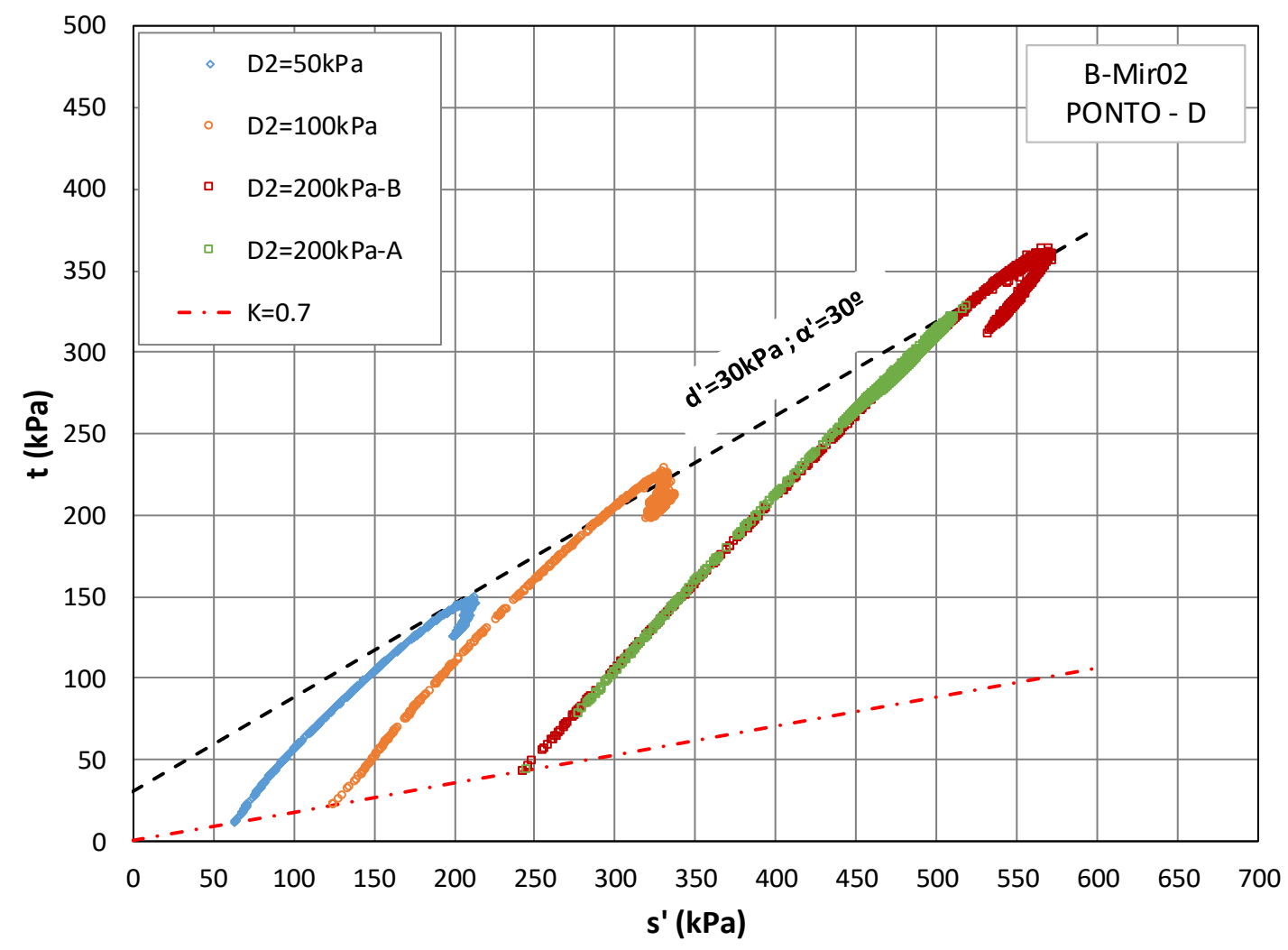

Figura 10-9 Trajetória de tensões efetivas para o ponto D2.

Da mesma forma que para a trajetória do ponto D2, observa-se que a trajetória de tensões do ponto O2 (Figura 10-11) apresentou pequenas variações de poropressões positivas até atingir a envoltória de ruptura. Após a ruptura passou a desenvolver variações negativas aonde os corpos de prova apresentam um aumento na sua resistência. Por ter a moldagem nas condições ótimas a resistência desenvolvida durante o processo de cisalhamento é maior comparado com os pontos D2 e W2.

Com relação ao ponto W2 observa-se que a sua trajetória de tensões efetivas apresentou o mesmo comportamento que os pontos D2 e O2. 


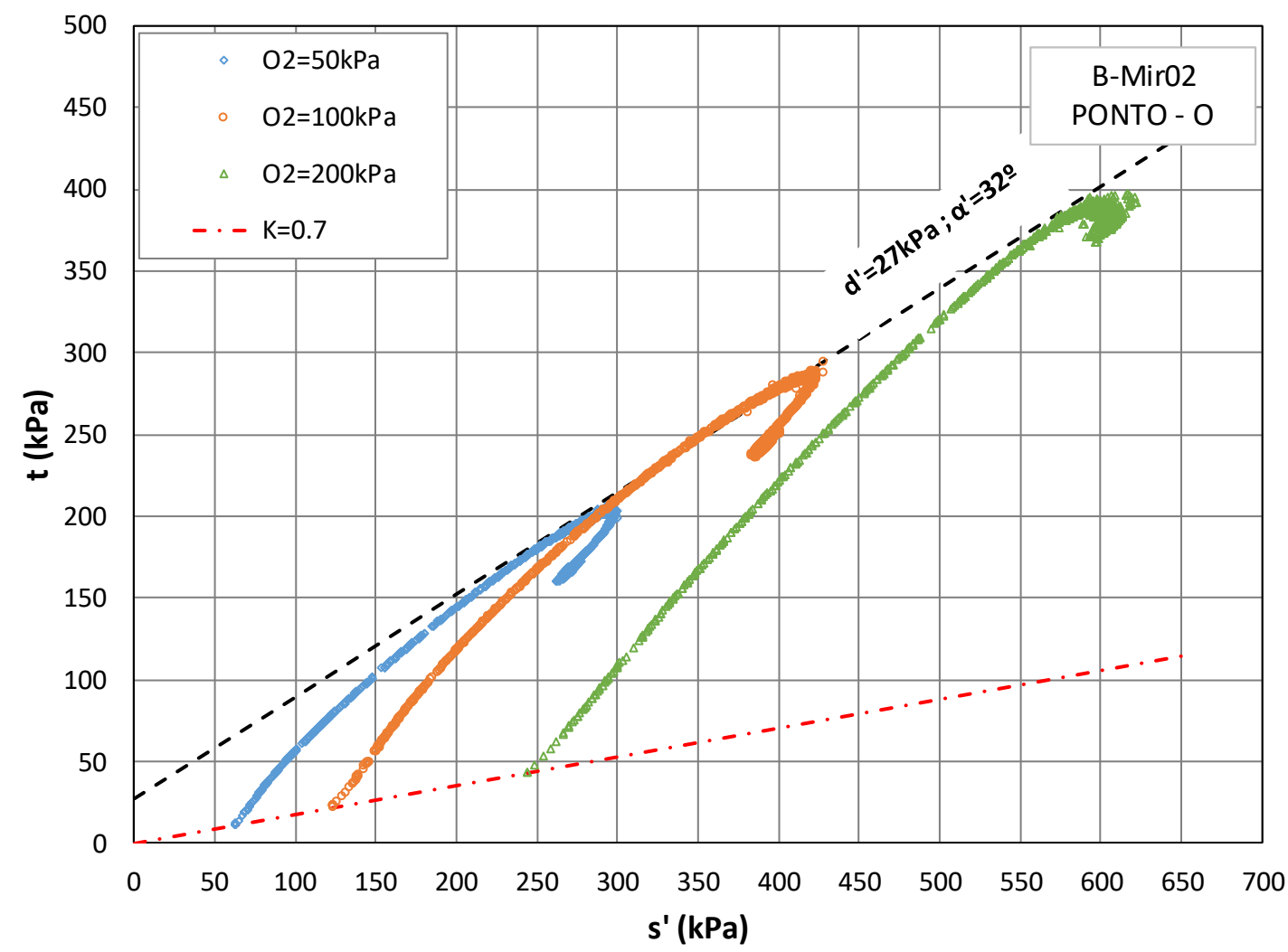

Figura 10-10 Trajetória de tensões efetivas para o ponto $\mathrm{O2.}$

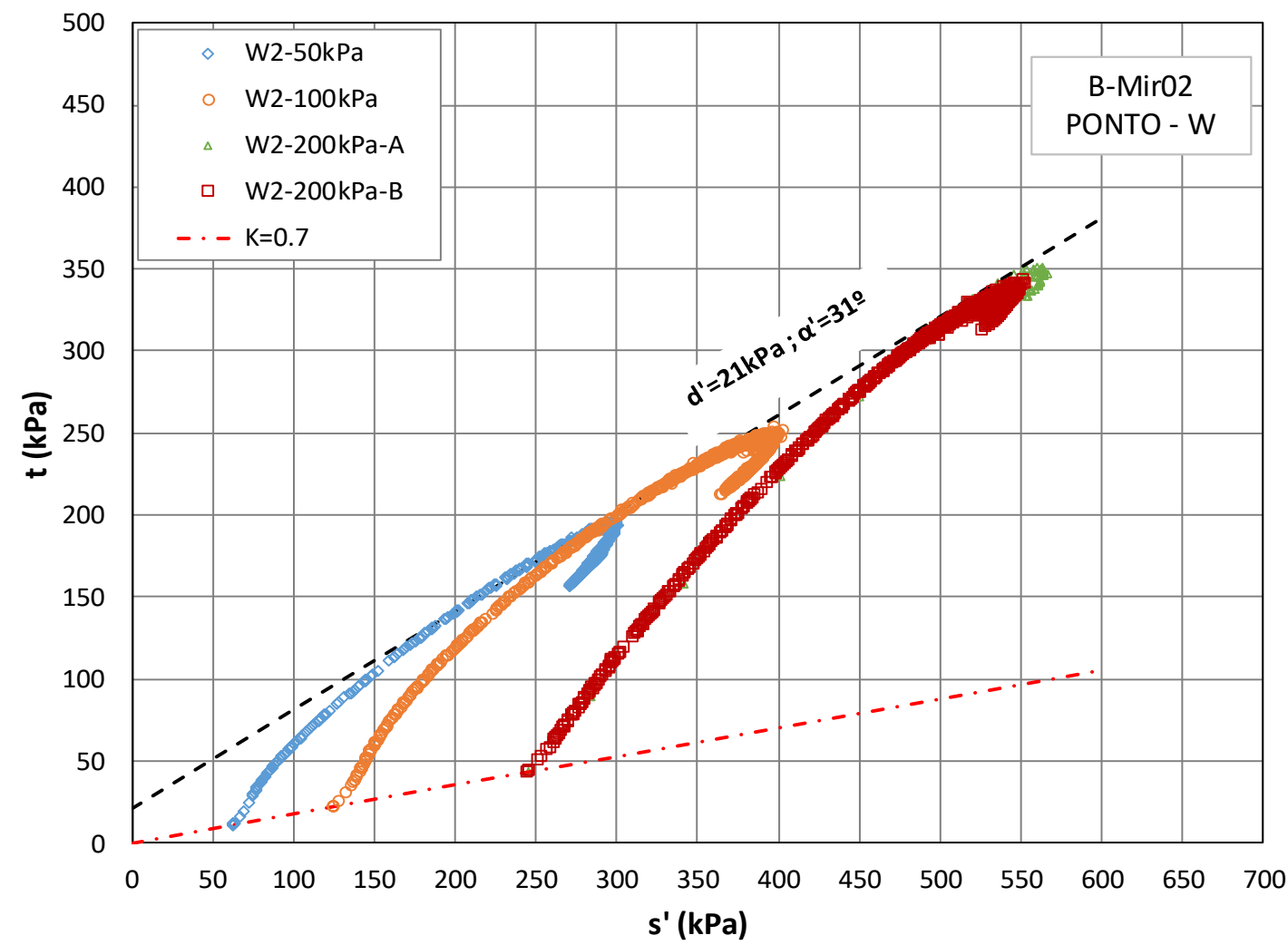

Figura 10-11 Trajetória de tensões efetivas para o ponto W2. 
10.4.3 Amostra B-Mir03 - Ponto D3:

A trajetória de tensões efetivas para a o ponto D3 (ramo seco) da amostra BMir03, está apresentada na Figura 10-12, aonde a envoltória de tensões efetivas foi obtida a partir da escolha dos valores máximos da curva de tensão desviadora normalizada. Pelo formato das trajetórias sob tensões de confinamento para 50 $\mathrm{kPa}$ e $100 \mathrm{kPa}$ se observa que pequenas variações de poropressões positivas se desenvolveram até atingir a ruptura, depois passaram a desenvolver pouca poropressão. Já para a tensão de confinamento de $200 \mathrm{kPa}$ se observa que, após a ruptura observou-se o desenvolvimento de poropressões positivas.

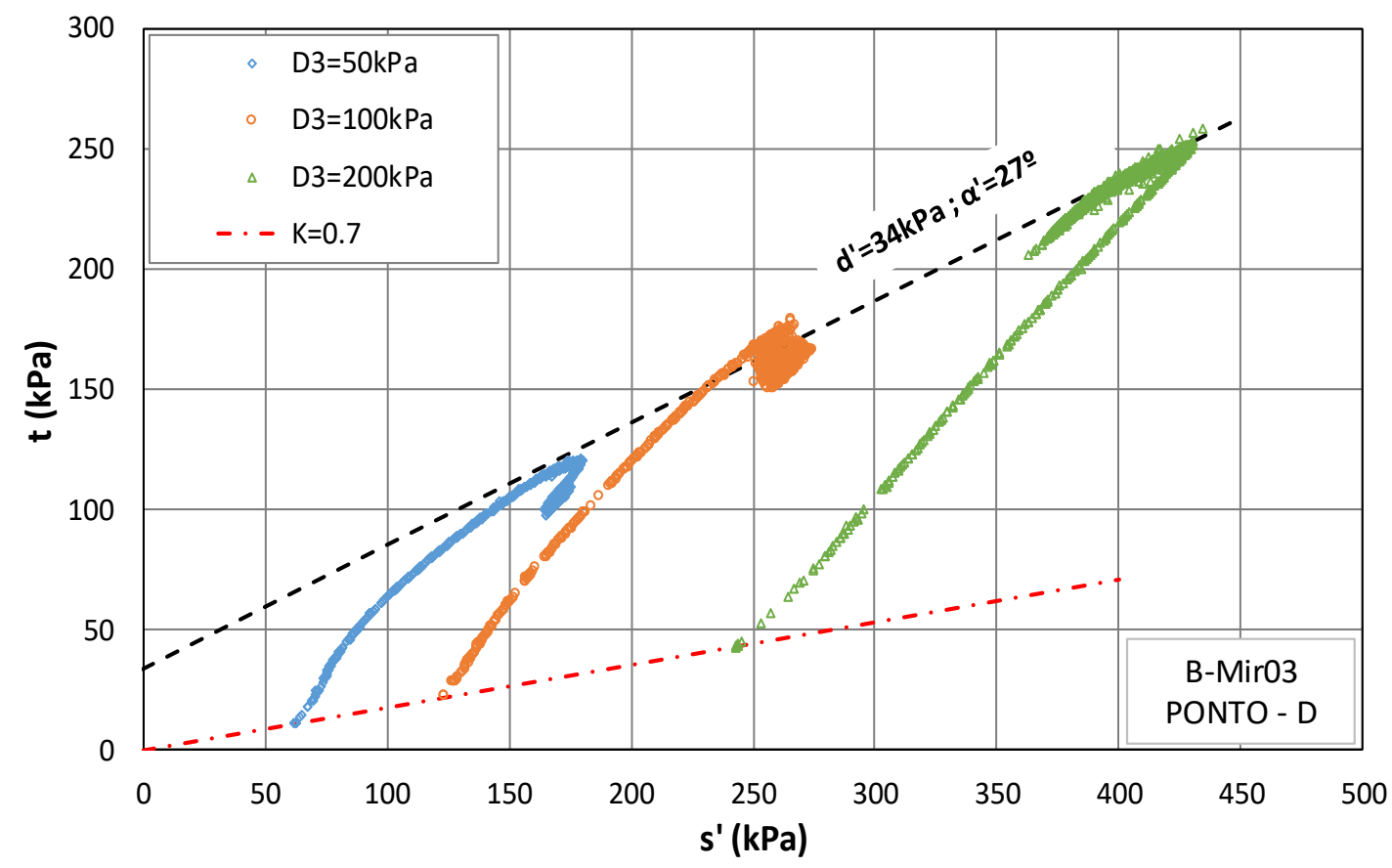

Figura 10-12 Trajetória de tensões efetivas para o ponto D3.

10.5 Envoltórias de ruptura

Nas Figuras 9-11 a 9-17 estão apresentados os círculos de Mohr e as envoltórias de cada conjunto de ensaios. Os valores de coesão e ângulo de atrito foram obtidos com base nas envoltórias das trajetórias de tensão efetiva.

10.5.1 Amostra B-Mir01:

A seguir são apresentadas as envoltórias de resistência para a amostra B-Mir01. A Figura 10-13 traz a envoltória do ponto D1(ramo seco), Figura 10-14 a envoltória correspondente ao ponto $\mathrm{O} 2$ (umidade ótima) e Figura 10-15 ponto W2 (ramo úmido). 
A partir destas envoltórias observa-se que em termos de ângulo de atrito o ponto O1 apresentou a maior coesão $(24 \mathrm{kPa})$ e ângulo de atrito $\left(35^{\circ}\right)$. O ponto $\mathrm{D} 1$ apresentou o menor ângulo de atrito $\left(25^{\circ}\right)$, porém uma coesão próxima a do ponto 01 . Já o ponto $\mathrm{W} 1$ apresentou um valor de coesão relativamente baixo (6 $\mathrm{kPa}$ ), porém um valor de ângulo de ângulo de atrito igual ao ponto $\mathrm{O}$.

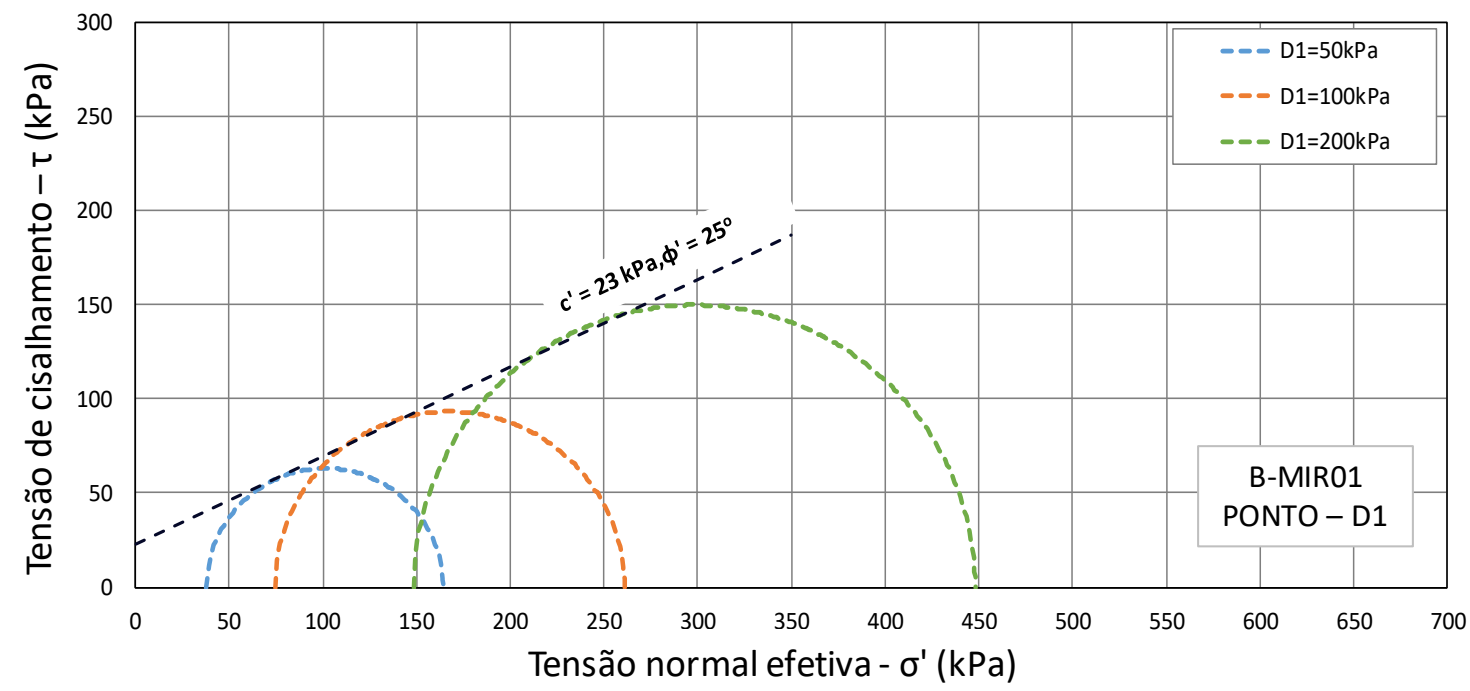

Figura 10-13 Círculos de Mohr obtidos para o ponto D1 e parâmetros de resistência efetiva a partir de ensaio triaxial CAU.

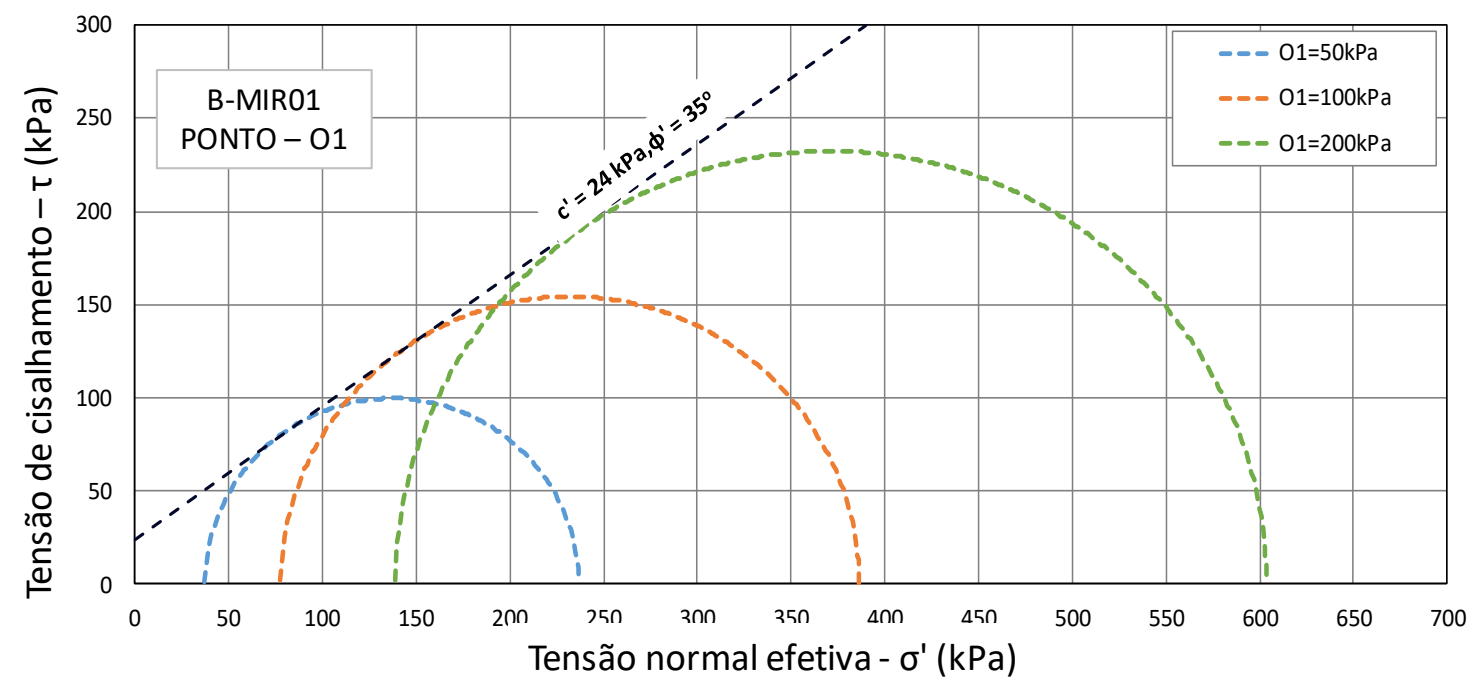

Figura 10-14 Círculos de Mohr obtidos para o ponto 01 e parâmetros de resistência efetiva a partir de ensaio triaxial CAU. 


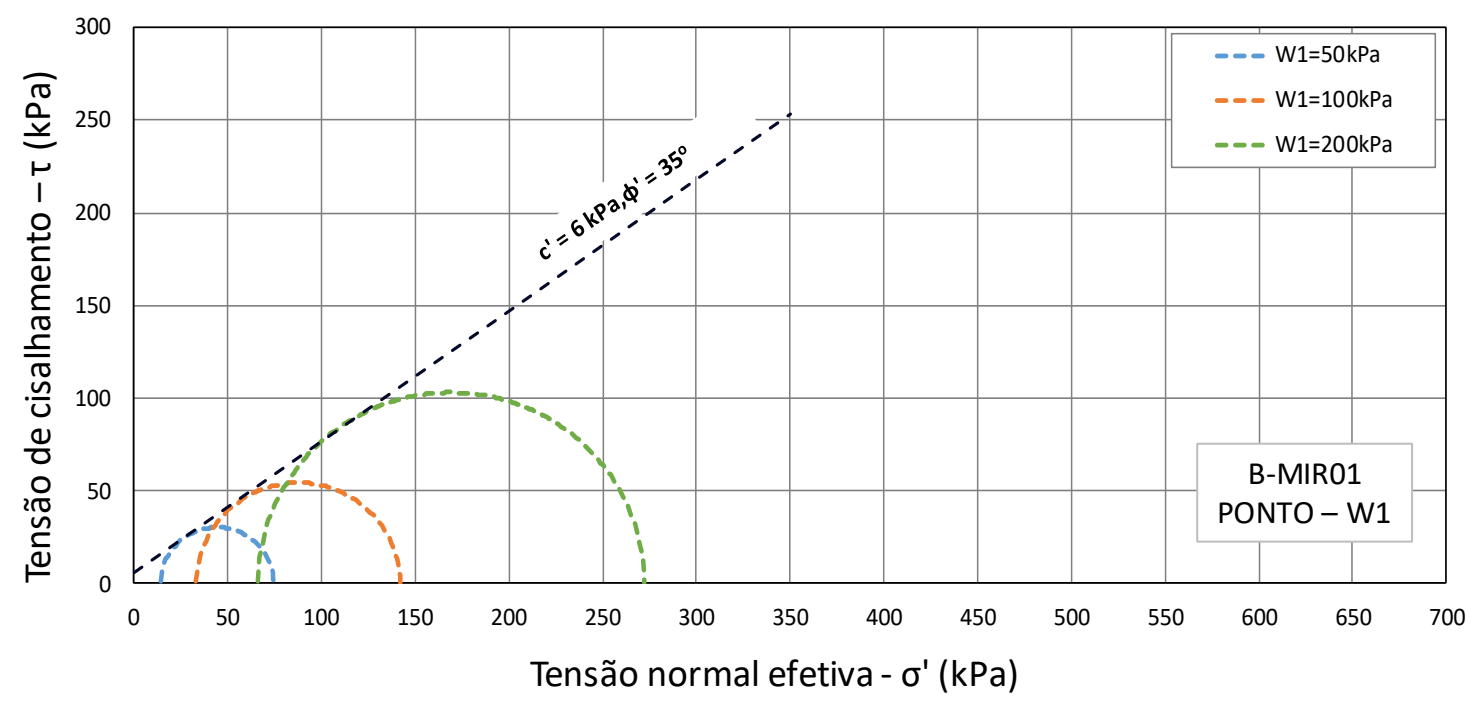

Figura 10-15 Círculos de Mohr obtidos para o ponto W1 e parâmetros de resistência efetiva a partir de ensaio triaxial CAU.

10.5.2 Amostra B-Mir02:

A seguir são apresentadas as envoltórias de resistência para a amostra B-Mir01. As Figura 10-16, Figura 10-17 e Figura 10-18 mostram as envoltórias para os pontos de estudo D2, O2 e W2 respectivamente.

Observa-se que em termos de ângulo de atrito o ponto $\mathrm{O} 2$ apresentou a maior ângulo de atrito $\left(39^{\circ}\right)$ comparados com o ponto D2 e W2 ambos com $35^{\circ}$. Para os valores de coesão o ponto D2 apresentou a maior coesão com $35 \mathrm{kPa}$, o ponto W2 apresentou o menor valor com $23 \mathrm{kPa}$; já o ponto na umidade ótima $\mathrm{O} 2$ com um valor de coesão de $32 \mathrm{kPa}$.

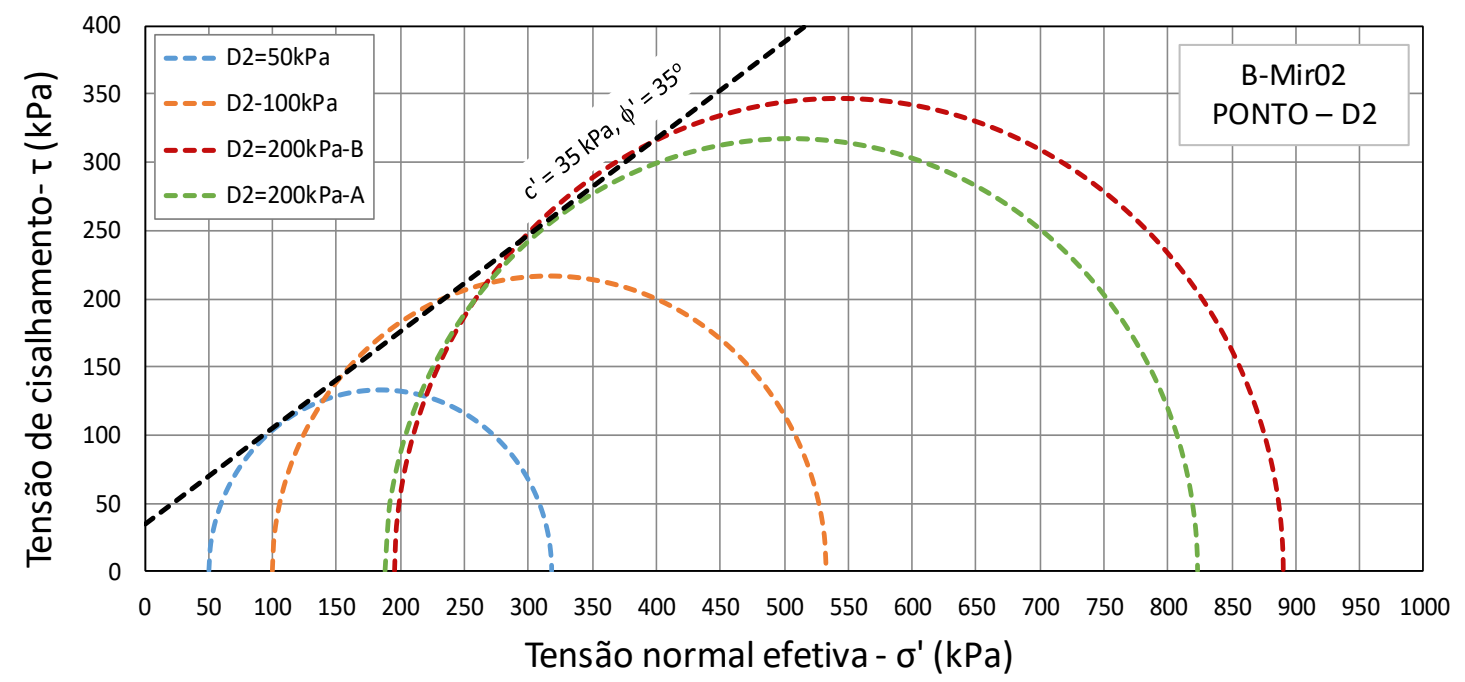

Figura 10-16 Círculos de Mohr obtidos para o ponto D2 e parâmetros de resistência efetiva a partir de ensaio triaxial CAU. 


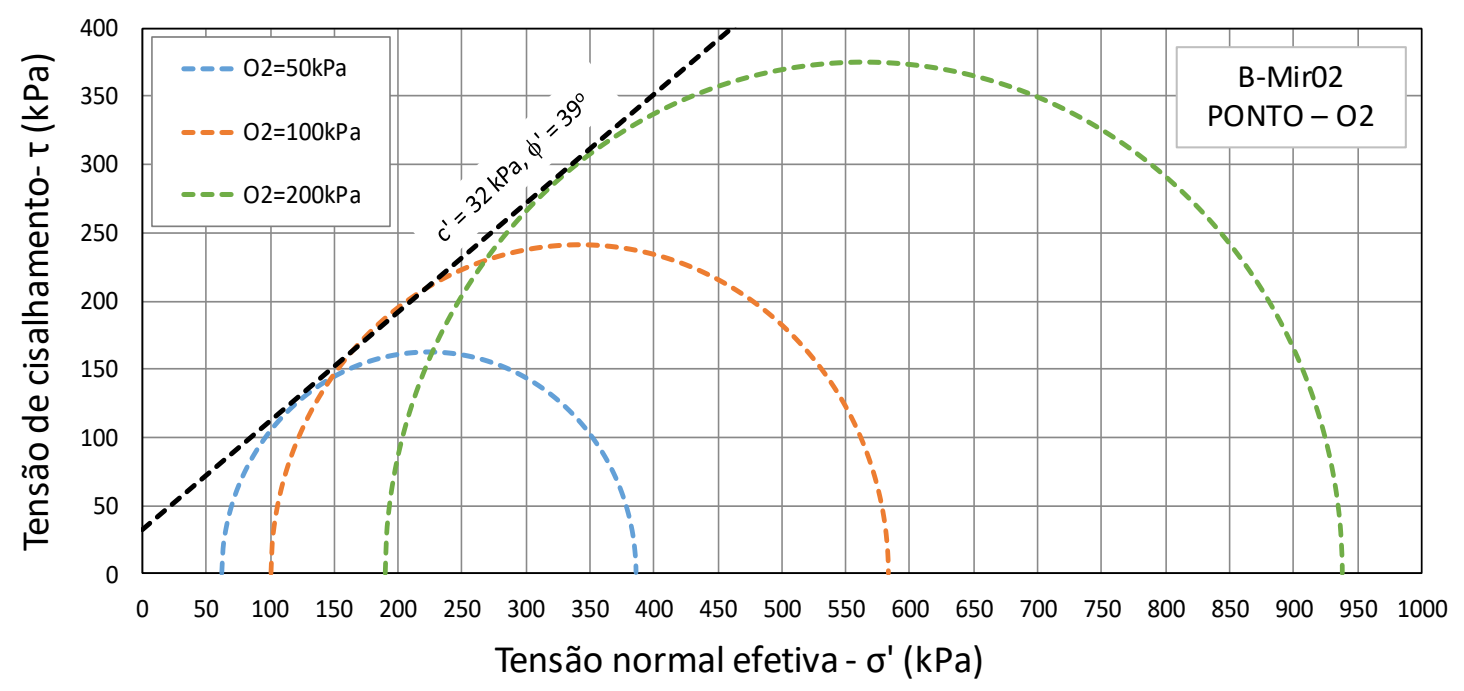

Figura 10-17 Círculos de Mohr obtidos para o ponto 02 e parâmetros de resistência efetiva a partir de ensaio triaxial CAU

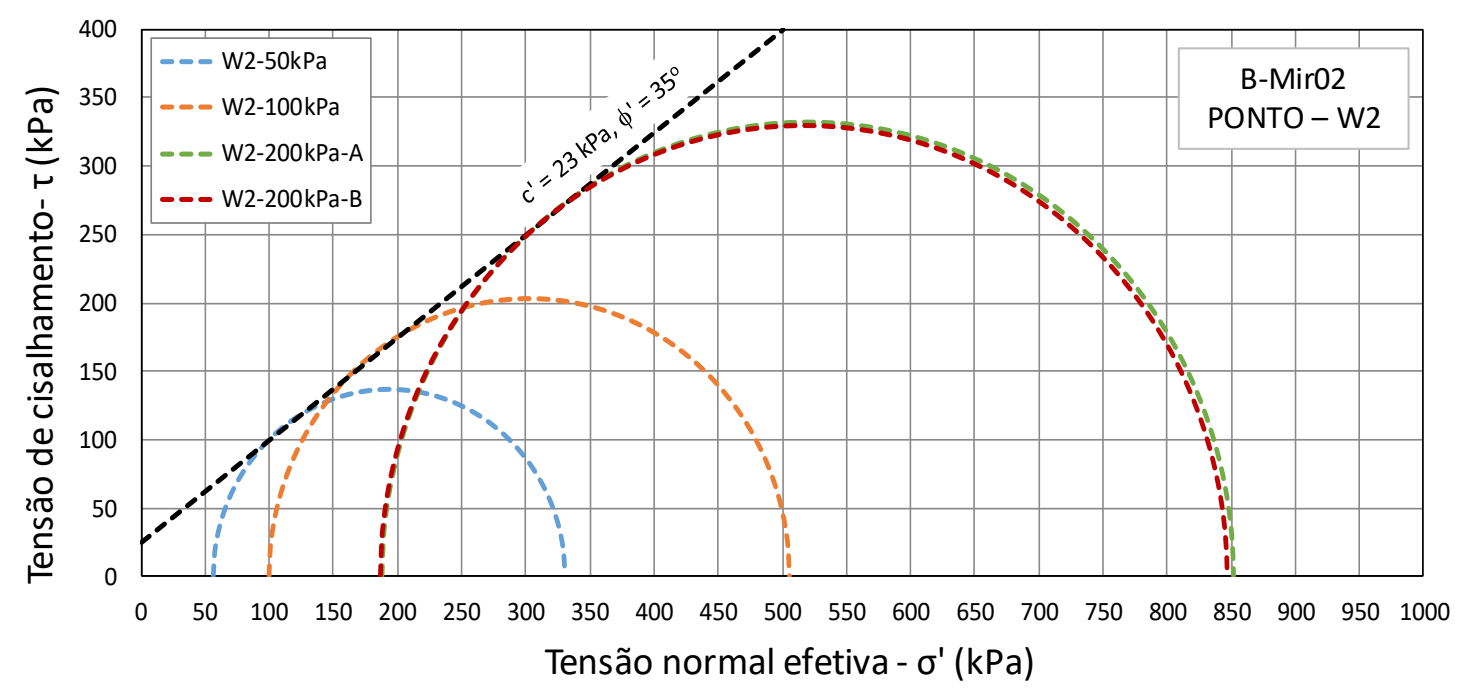

Figura 10-18 Círculos de Mohr obtidos para o ponto W2 e parâmetros de resistência efetiva a partir de ensaio triaxial CAU.

10.5.3 Amostra B-Mir03 - Ponto D3:

A seguir são apresentadas na Figura 10-19 as envoltórias de resistência para a amostra B-Mir03 para o ponto no ramo seco D3, a partir desta envoltória se obteve o valor de $31^{\circ}$ para o ângulo de atrito e uma coesão de $38 \mathrm{kPa}$. 


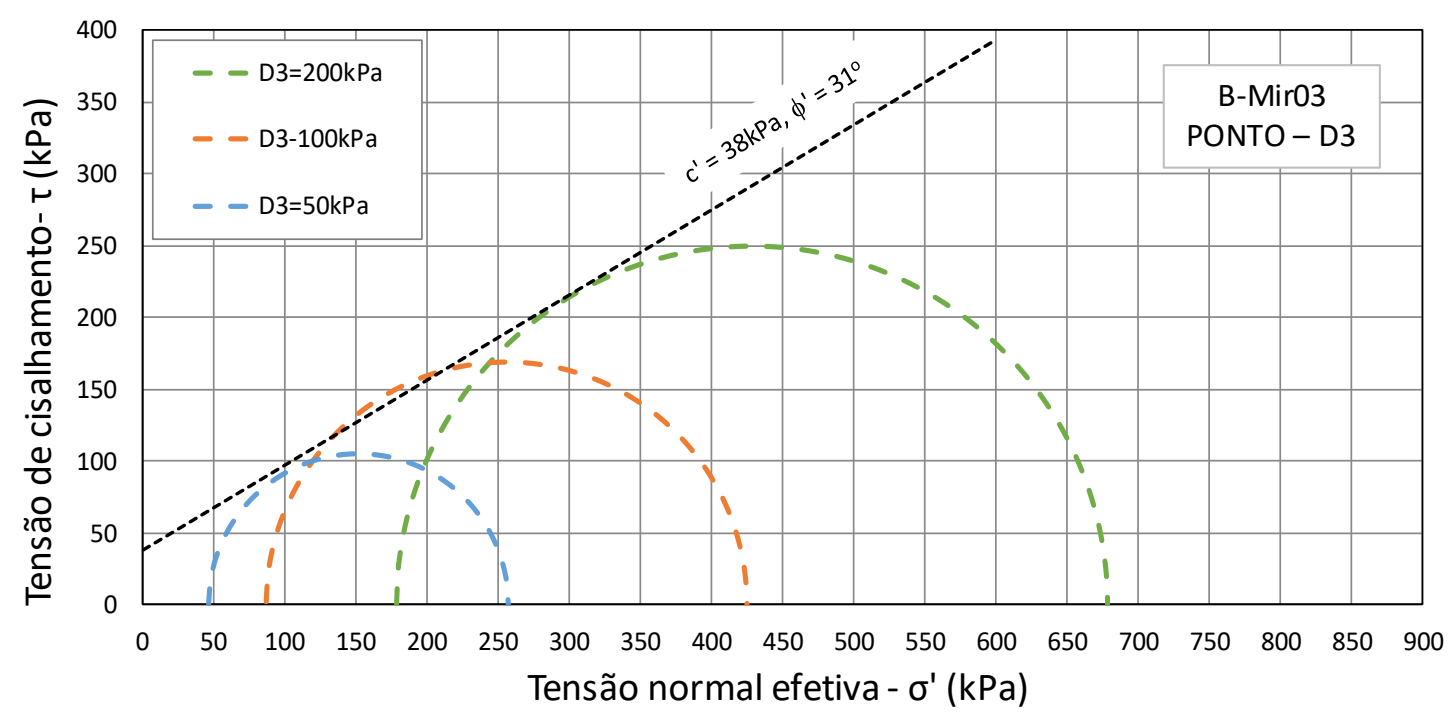

Figura 10-19 Círculos de Mohr obtidos para o ponto D3 e parâmetros de resistência efetiva a partir de ensaio triaxial CAU.

A Tabela 10-2 apresenta um resumo geral dos parâmetros de resistência obtidos para as três amostras de rejeito nas três condições de compactação.

Tabela 10-2 - Resultados dos parâmetros de resistência. Coesão e ângulo de atrito

\begin{tabular}{cccc}
\hline \multirow{2}{*}{ Amostra } & $\begin{array}{c}\text { Condições de } \\
\text { Compactação }\end{array}$ & $\mathbf{c}^{\prime}(\mathbf{k P a})$ & $\mathbf{\phi}^{\prime}\left({ }^{\circ}\right)$ \\
\hline \multirow{3}{*}{ B-Mir01 } & Seco - D1 & 23 & 25 \\
& Ótimo - O1 & 24 & 35 \\
\cline { 2 - 4 } & Úmido - W1 & 6 & 35 \\
\hline \multirow{2}{*}{ B-Mir02 } & Seco - D2 & 35 & 35 \\
& Ótimo - O2 & 32 & 39 \\
\hline B-Mir03 & Úmido - W2 & 24 & 37 \\
\hline
\end{tabular}

Para melhor visualização e comparação dos resultados, são apresentados na Figura 10-20 os resultados em forma de gráfico de barras.

Comparando os resultados de todos os pontos no ramo seco (D1, D2 e D3), se observa que os valores de coesão foram os maiores se comparados aos demais.

A amostra B-Mir01 teve sua moldagem com variação de umidade de $5 \%$, esta condição se reflete principalmente no resultado da coesão aonde o valor mais baixo pertence à condição mais úmida (amostra que apresentou metaestabilidade). 
No caso das amostras B-Mir02 por se tratar de um material não plástico era esperado apresentar valores de coesão mais baixos. Salienta-se que os pontos de estudo tiveram uma variação de teor umidade de moldagem baixa (aproximadamente $2 \%$ ).

De forma geral, a condição de umidade ótima para as amostras B-Mir01 e BMir03 apresentaram melhores parâmetros de resistência.

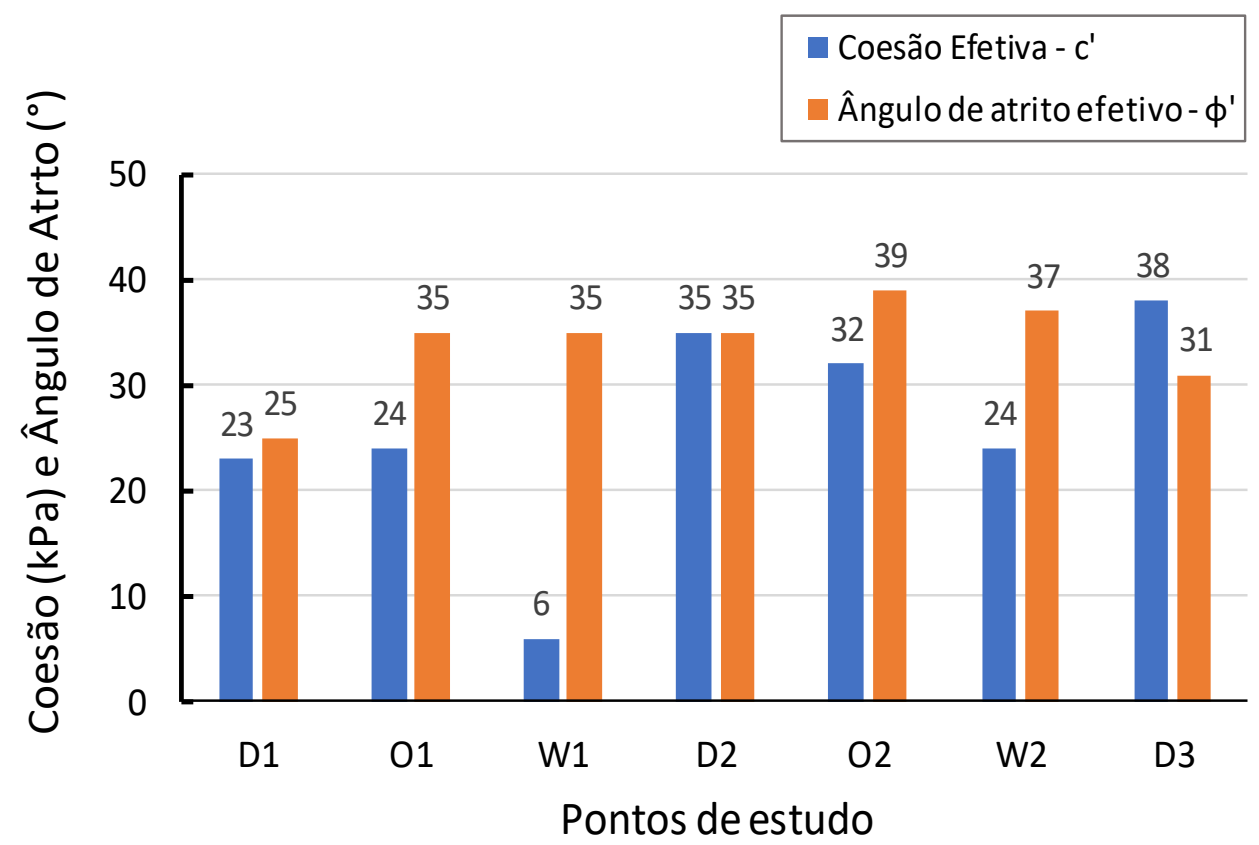

Figura 10-20 Resultados dos parâmetros de resistência. Coesão e ângulo de atrito 10.6 Módulos de deformabilidade.

Os módulos de deformabilidade secante $\left(E_{s}\right)$ foram obtidos a partir dos resultados dos ensaios triaxiais tipo CAU, sendo possível obter dados a partir de deformações de $0.01 \%$ (embora com alguma variabilidade). Salienta-se que o sistema de medição de deslocamentos foi externo.

Os resultados dos módulos secantes para pequenas deformações $(0.1 \%)$ e as deformações na ruptura estão apresentados na Tabela 10-3 aonde se observa que o módulo reduz seus valores para maiores deformações, como esperado. 
Tabela 10-3 - Resultados dos módulos de deformabilidade secante (Es) para as amostras B-Mir01, B-Mir02 e B-Mir03.

\begin{tabular}{|c|c|c|c|}
\hline Amostra & Condições de Compactação & $E-0.1 \%$ & E-Ruptura\% \\
\hline \multirow{9}{*}{ B-Mir01 } & D1-50 & 335.90 & 130.00 \\
\hline & D1-100 & 535.92 & 84.52 \\
\hline & D1-200 & 1234.78 & 175.72 \\
\hline & $01-50$ & 420.79 & 165.67 \\
\hline & $01-100$ & 662.75 & 229.49 \\
\hline & $01-200$ & 1129.20 & 190.69 \\
\hline & W1-50 & 323.00 & 17.69 \\
\hline & W1-100 & 346.60 & 31.35 \\
\hline & W1-200 & 921.90 & 21.10 \\
\hline \multirow{11}{*}{ B-Mir02 } & $\mathrm{D} 2-50$ & 210.89 & 171.63 \\
\hline & $\mathrm{D} 2-100$ & 540.59 & 249.65 \\
\hline & D2-200-A & 926.00 & 321.41 \\
\hline & D2-200-B & 683.49 & 343.79 \\
\hline & $01-50$ & 328.00 & 193.58 \\
\hline & $01-100$ & 506.86 & 225.30 \\
\hline & $01-200$ & 863.11 & 389.58 \\
\hline & W1-50 & 330.89 & 171.80 \\
\hline & W1-100 & 484.16 & 234.79 \\
\hline & W1-200-A & 754.17 & 302.10 \\
\hline & W1-200-B & 682.18 & 255.29 \\
\hline \multirow{3}{*}{ B-Mir03 } & D3-50 & 343.64 & 122.57 \\
\hline & D3-100 & 372.55 & 214.04 \\
\hline & D3-200 & 901.96 & 276.21 \\
\hline
\end{tabular}

Para melhor visualização os módulos de deformabilidade secante de cada amostra serão apresentados no formato de gráfico de barras em função da tensão confinante efetiva de ensaio.

Os resultados para a amostra B-Mir01 estão apresentados na Figura 10-21. A partir deste gráfico se observa que em todos os pontos de estudo D1, O1 e W1 os máximos valores de módulos de deformabilidade secante para deformações de $0.1 \%$ estão relacionados diretamente com o nível de confinamento inicial efetivo para o qual foi submetida a amostra. Esta tendência não se observa quando analisados os módulos para deformações correspondentes a ruptura.

Os máximos valores de módulo para $0.1 \%$ de deformação foram para a condição do ramo seco e na umidade ótima. 


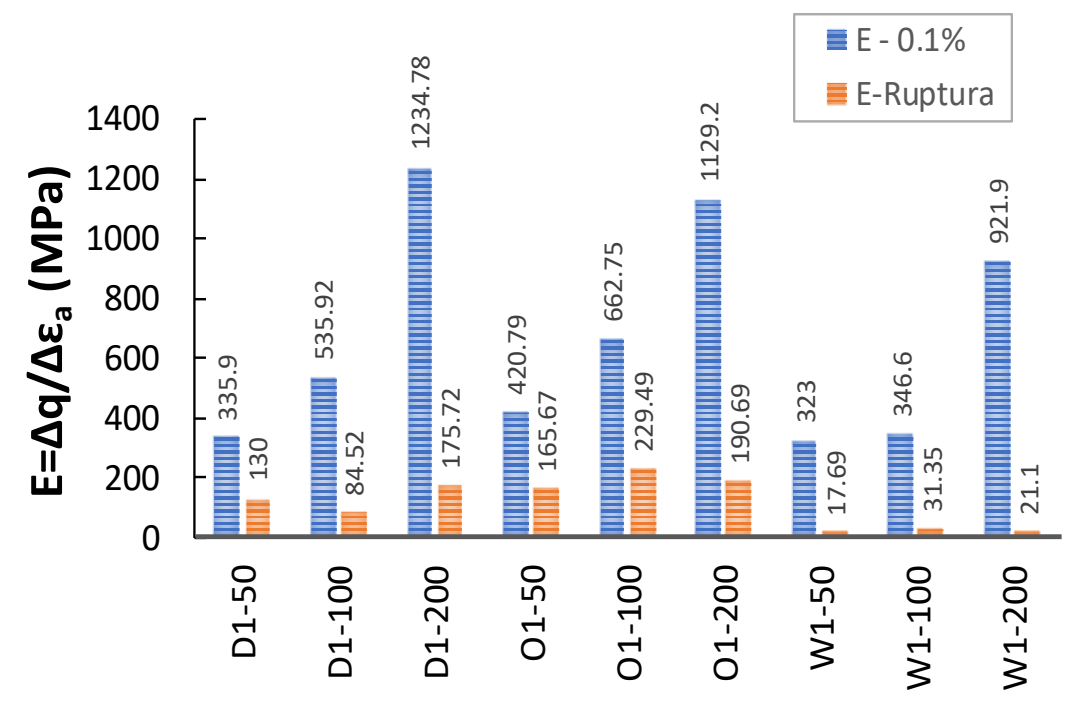

Figura 10-21 Módulos de deformabilidade secante (E) - B-Mir01.

Da mesma forma que a amostra B-Mir01, os módulos de deformabilidade secante correspondentes à amostra B-MIR02, mostrada na Figura 10-22, apresenta, como esperado, que os máximos valores do módulo para baixas deformações $(0.1 \%)$. Observa-se pouca variabilidade se comparados todos os resultados dos pontos de estudo, situação que talvez possa ser devido ao fato das umidades de moldagem serem próximas. Com relação ao módulo na ruptura para a amostra B-Mir02 observou-se uma relação direta com o estado de confinamento.

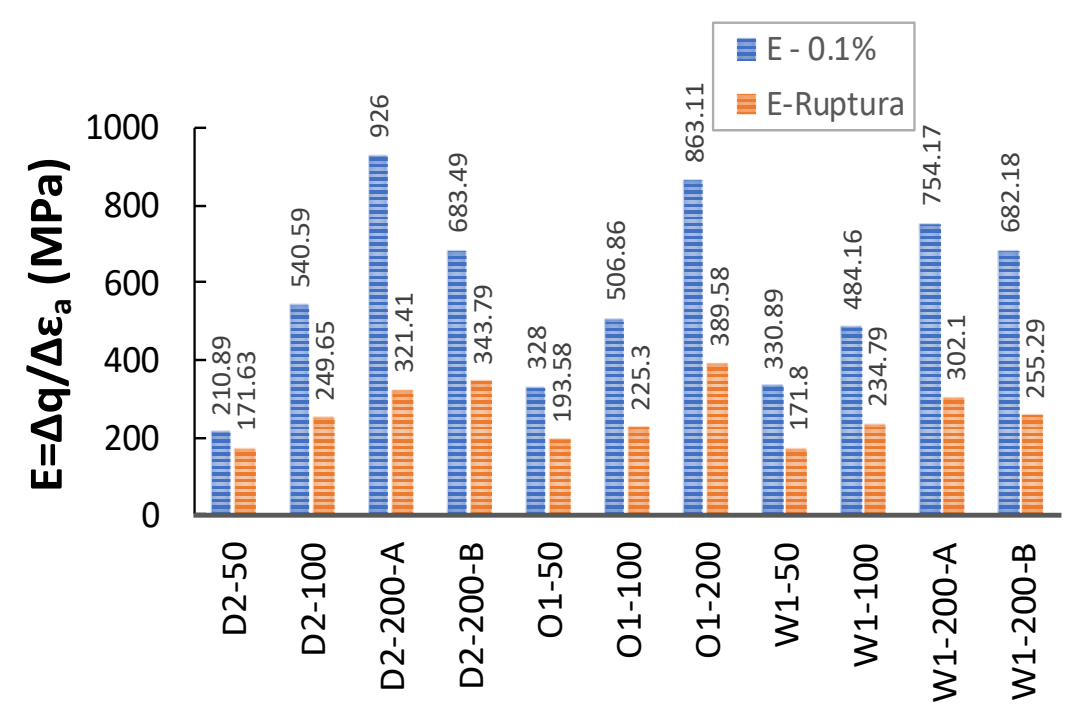

Figura 10-22 Módulos de deformabilidade secante (E) - B-Mir02

Para o ponto D3 da amostra B-Mir03 na Figura 10-23, observa-se que os valores dos módulos, tanto para baixas deformações quanto para o caso da ruptura apresentam relação direta com o valor da tensão de confinamento. 


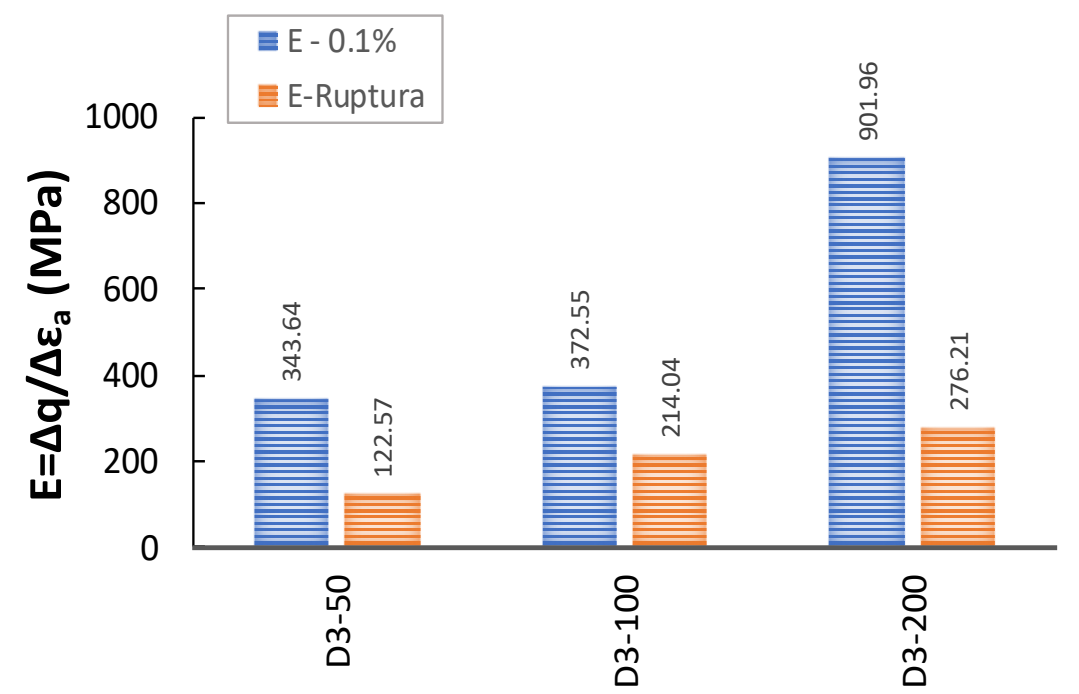

Figura 10-23 Módulos de deformabilidade secante (E) - B-Mir03 ponto D3

Com o objetivo de avaliar de avaliar o nível de tensões se calculou o módulo de deformabilidade secante normalizado, aonde cada modulo de deformabilidade secante obtido foi dividido pela sua própria tensão efetiva média atuante $\left(p^{\prime}\right)$ onde:

$p^{\prime}=\frac{\sigma_{1}{ }^{\prime}+2 \sigma_{3}}{3}$

Os resultados o modulo de deformabilidade secante normalizado sob diversas tensões de confinamento efetivo estão apresentados na Figura 10-24a para a amostra B-Mir01, Figura 10-24b para a amostra B-Mir02 e Figura 10-24c para BMir03 no ponto D3.

O comportamento geral dos dados plotados com o módulo normalizados indicam, como esperado, uma redução com o nível de deformação. Observa-se alguma variação na tendência da normalização, como função da tensão confinante em cada ensaio.

Em todas as amostras pode ser visto que o módulo normalizado se mostra similar para uma deformação de $0.1 \%$, com uma pequena tendência de apresentar maiores valores para a amostra B-Mir01. 

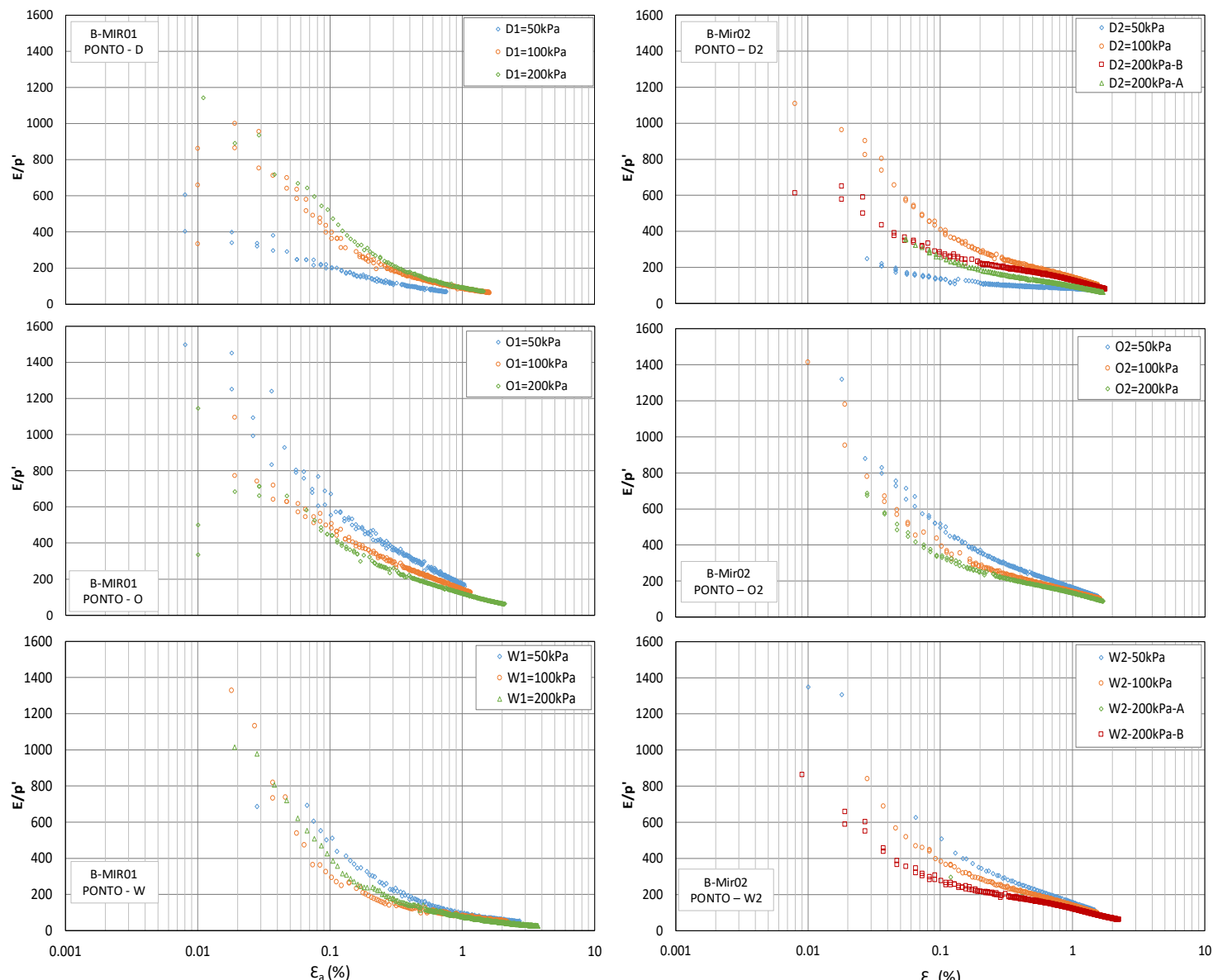

(a)

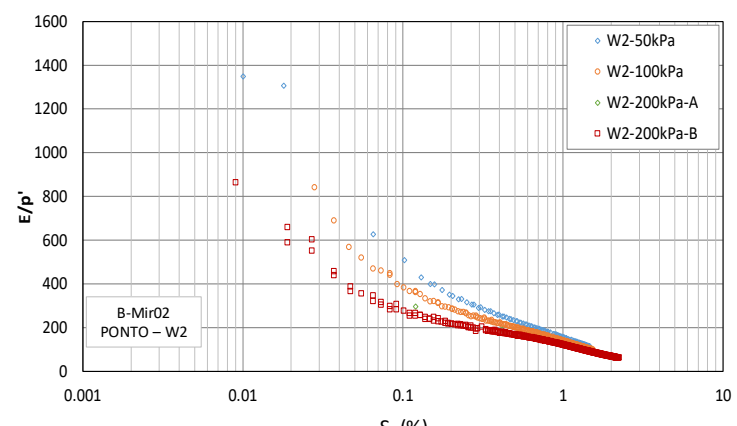

(b)

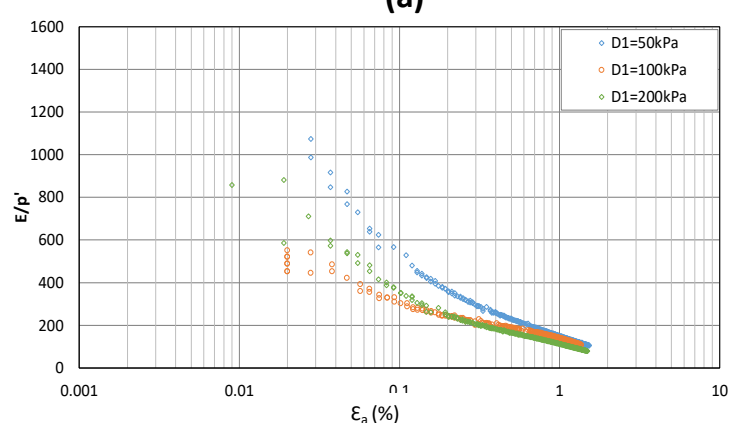

(c)

Figura 10-24 Módulos de deformabilidade secante normalizados para todas as amostras ensaiadas. (a) B-Mir01, (b) B-Mir02 e (c) B-Mir03-Ponto D3 


\section{CONCLUSÕES}

Três amostras de rejeitos de bauxita foram coletadas nas instalações de uma usina de beneficiamento localizada no Município de Miraí em Minas Gerais. As amostras denominadas B-Mir01 e B-Mir 02 foram coletadas na praia de rejeitos. A terceira amostra denominada B-Mir03 foi coletada na própria planta de beneficiamento.

Todas as amostras foram caracterizadas do ponto de vista geotécnico de modo a determinar sua natureza. Após esta caracterização, verificou-se a existência de uma heterogeneidade em todos os materiais. Uma das causas é devido à mudança de área de exploração, uma vez que a área com o conteúdo mineral desejado foi esgotada, novas áreas com teores de minério desejados passam a ser exploradas e beneficiadas. Também com o avanço da tecnologia, novas formas de tratamento, com a finalidade de otimizar a extração do minério, são instaladas dentro da usina, fazendo com que mudem as características dos rejeitos.

Os rejeitos por serem materiais tratados dentro da usina não são mais naturais, devem ser considerados como materiais artificiais e se deve tomar especial cuidado quando avaliado o seu comportamento. Após estas considerações seguem as seguintes conclusões para as três amostras investigadas:

- A amostra B-Mir01 coletada em fevereiro de 2016 foi identificada como uma argila arenosa; a amostra B-Mir02 coletada em setembro/2016, como uma areia siltosa sem plasticidade. Já a amostra B-Mir03 trata-se de uma argila silto-arenosa, também coletada em setembro/2016 na própria usina antes do lançamento.

- A partir das análises de fluorescência de raios $\mathrm{x}$ e difratometria de raios $\mathrm{x}$, observou-se que todas as amostras de rejeito possuem elevado teor de alumina, o que significa que num futuro podem voltar para a cadeia de beneficiamento. A partir disto se destaca a importância deste estudo com relação a obtenção dos parâmetros geotécnicos já que são necessários para a elaboração de projetos de eventual empilhamento.

A partir dos resultados dos ensaios oedômetricos realizados em todas as amostras. Se observa que os índices de compressão (Cc) da B-Mir01 variaram 
entre 0.30 e 0.36 , para B-Mir02 entre (0.08 e 0.06), o que mostra que as características de compressibilidade continuaram guardando relação com a natureza do material. Já o índice de compressão da amostra B-Mir03 $(\mathrm{Cc}=0.06)$ na condição de umidade ótima ficou abaixo do esperado. Todas as amostras adensaram rapidamente em todas as tensões solicitadas e não foi possível obter o coeficiente de adensamento (Cv).

Para determinar e comparar os parâmetros de resistência ao cisalhamento, foram realizados ensaios triaxiais do tipo CAU, que permitiu avaliar 0 desenvolvimento de poropressão de água. As amostras foram moldadas em diferentes posições ao longo da curva de compactação Proctor normal obtida para cada amostra. Seguem as conclusões:

- A amostra B-Mir01 apresentou diferentes trajetórias de tensões para os três pontos testados. Os corpos de prova compactados no ramo seco e acima da ótima apresentou um abrupto aumento da poropressão na ruptura. Este comportamento sugere metaestabilidade nestas condições. A umidade do material tem um papel importante neste comportamento.

- Os resultados da amostra B-Mir02, sugerem que o material não apresenta qualquer tendência para desenvolvimento de poropressoes que possa induzir liquefação, independentemente do ponto de compactação. A amostra B-Mir03, compactada no ramo seco, comportou-se de forma semelhante ao B-Mir02 também no ramo seco.

- Foi observada uma certa variabilidade para a coesão efetiva que variou de $6 \mathrm{kPa}$ a $24 \mathrm{kPa}$ para B-Mir01 e de $24 \mathrm{kPa}$ a $35 \mathrm{kPa}$, para B-Mir02. O ângulo de fricção variou de $25^{\circ}$ a $35^{\circ}$ para B-Mir01 e de $35^{\circ}$ a $39^{\circ}$ de $B$ Mir02. A amostra B-Mir03, compactada no ramo seco apresentou coesão de $38 \mathrm{kPa}$ e ângulo de atrito efetivo de $31^{\circ}$.

- O máximo valor do módulo de deformabilidade secante normalizado $\left(E / p^{\prime}\right)$ apresentou um valor de cerca de 1200 para B-Mir01 e aproximadamente 1000 para B-Mir02. Para um nível de deformação de $0,1 \%$, o módulo normalizado apresentou próximos para todas as amostras e igual a 400 . O mesmo foi observado para as amostras B-Mir03.

A variabilidade observada nos materiais coletados, tanto do ponto de vista de natureza como do ponto de vista de comportamento mecânico, sugere 
fortemente que deva ser avaliada cuidadosamente o uso de rejeito como material de aterro.

Os resultados obtidos para as três amostras indicam uma variação para os dados de resistência ao cisalhamento e uma menor variabilidade em termos de deformabilidade. Foi demostrado que as amostras ensaiadas nas condições de umidade ótima apresentam um bom comportamento mecânico para uso em obras de aterro. Deve-se assim observar a umidade de compactação para evitar estruturas que possam levar a materiais metaestáveis. 


\section{RECOMENDAÇÕES}

Com base nos estudos realizados e análises realizadas apresentam-se a seguir algumas recomendações que objetivam melhor compreender o comportamento geomecânico dos rejeitos de bauxita lavada:

a) Realizar ensaios de caracterização geotécnica do rejeito in natura de modo a comparar os efeitos com os ensaios realizados por via seca.

b) Realizar ensaios de permeabilidade para entender o comportamento do fluxo uma vez que o material será utilizado em obras de aterro.

c) Definição de novos pontos de estudo com maior variação do teor de umidade de compactação, de modo a observar os efeitos na resistência, compressibilidade e deformabilidade do rejeito.

d) Realização de novos ensaios triaxiais não drenados do tipo CAU, com tensões confinantes efetivas menores para melhor definição do intercepto de coesão efetiva.

e) Finalização dos ensaios triaxiais da amostra B-Mir03 para análise do seu comportamento nas condições de umidade ótima e no ramo úmido.

f) Realização de análises de microscopia eletrônica de varredura - MEV para melhor entendimento da estrutura do material nas diversas condições de moldagem.

g) Estudar o comportamento do rejeito na condição não saturada. Obtendo-se suas curvas de retenção e realizando ensaios de resistência com medição ou controle da sucção.

h) Propor uma rotina simples de análise do potencial de liquefação dos rejeitos por meio de ensaios de caracterização geotécnica (granulometria, densidade dos grãos e limites de consistência).

i) Elaboração de procedimentos de controle tecnológico que permita a aplicação do rejeito na condição de umidade ótima quando utilizado em obras de aterro. 


\section{REFERÊNCIAS}

AMERICAN SOCIETY FOR TESTING AND MATERIALS - ASTM. ASTM D4767-11 (2011) Standard Test Method for Consolidated Undrained Triaxial Compression Test for Cohesive Soils, West Conshohocken, PA. 14p. https://doiorg.ez67.periodicos.capes.gov.br/10.1520/D4767-11

ASSOCIAÇÃO BRASILEIRA DE NORMAS TÉCNICAS - ABNT. NBR 6457 (2016) Amostras de solo - preparação para ensaios de compactação e ensaios de caracterização. São Paulo

. NBR 6458 (2016). Grãos de pedregulho retidos na peneira de abertura 4,8 mm determinação da massa específica, da massa específica aparente e da absorção de água. São Paulo. 10p

. NBR 6459 (2016). Determinação do limite de liquidez. São Paulo. 5p

. NBR 7180 (2016). Determinação do limite de plasticidade. São Paulo. 3p

. NBR 7481 (2016). Solo - análise granulométrica. São Paulo. 12p

. NBR 7482 (2016). Solo - ensaio de compactação. São Paulo. 13p

ASSOCIAÇÃO BRASILEIRA DE ALUMÍNIO - ABAL. (2017) Alumínio brasileiro:

Soluções para uma vida sustentável. São Paulo. Associação Brasileira de Alumínio, p 61.

ANDRADE, C.F.; BIGOGNO, N.C.; DE SOUZA, T.F.; CHAVES, A.P.(2012). CBA'S Miraí processig plant. 19th International Symposium ICSOBA-2012, "Bauxite, Alumina and Aluminium Industry in Brazil and New Global Developments" 10p

ALMEIDA, E.B. (1977). Geology of the bauxites deposits of the Poços de Caldas District, State of Minas Gerais. Ph.D.Thesis, Stanford University, p 256.

ALEVA, G.J.J. (1981). Essential differences between the bauxite deposits along the Southern and Northern Edges of the Guiana shield, South America. Economic Geology. 76 (5):1142-1152.

BATES, J. (2003). Barragens de Rejeitos. 1. ed. São Paulo: Signus. 122p

BÁRDOSSY, G. (1982), Karst Bauxites. Bauxite deposits on carbonate rocks. Amsterdam, Elsevier Developments in Economic Geology 17, p.441.

BÁRDOSSY, G. (1994), Carboniferous to Jurassic bauxite deposits as paleoclimatic and paleogeographic indicators. Canadian Society of Petroleum Geologists, Memoir 17, p. 283-293.

BÁRDOSSY, G.; ALEVA, G.J.J. (1990), Lateritic bauxites. Amsterdam, Elsevier, Developments in Economic Geology 27, p. 624

BEDIN, J. (2006), Interpretação de ensaios de piezocone em resíduos de bauxita. Dissertação. Programa de Pós-Graduação em Engenharia Civil, UFRGS, Porto Alegre. 256p

BEDIN, J. (2010), Estudo do Comportamento Geomecânico de Rejeitos de Mineração. Tese de doutorado em Engenharia. Programa de Pós-Graduação em Engenharia Civil, UFRGS, Porto Alegre.

BISHOP, A.W.; WESLEY, L.D. (1975), A hydraulic triaxial apparatus for controlled stress path testing. Geotechnique Vol 25(1) p. 657-670.

BOGATYREV, B.A.; ZHUKOV, V.V. (2009) Bauxite provinces of the world: Geology of Ore Deposits, v. 51, no. 5, p. 339-355. 
BOURNAY. E.; HERBELEIN C. (2006) Vital Waste Graphics 2, GRID-Arendal / UNEP / The Basel Convention Secreteriat. 44 p. Disponível: https://www.grida.no/publications/257

CARVALHO, A. (1989) As Bauxitas no Brasil: Síntese de um programa de pesquisa. Tese de Livre Docência. Instituto de Geociências. Universidade de São Paulo, São Paulo. 134p

CHAVES, A. P.(2012). Teoria e Prática do Tratamento de Minérios - Manuseio de sólidos granulados. 2. ed. São Paulo: Oficina de Textos. v. 1. 384p.

COSTA, J.H.B., \& DELBONI J.H. (2012), Escrubagem da bauxita de Paragominas - PA: Parte 1: influência de variáveis operacionais na desagregação da bauxita. Rem: Revista Escola de Minas, 65(2), 257-262.

DE CASTRO, L.V.P. (2008) Avaliação do comportamento do nível d'água em barragem de contenção de rejeito alteada a montante. Dissertação de mestrado Departamento de Engenharia Mineral, Escola Politécnica, Universidade de São Paulo, São Paulo. 103p.

DENNEN, W. H., NORTON, H. A. (1977). Geology and geochemistry of bauxite deposits in the lower Amazon Basin. Economic Geology, 72 (1):82-89p

DEPARTAMENTO NACIONAL DE PRODUÇÃO MINERAL- DNPM (2016). Anuário Mineral Brasileiro: Principais Substâncias Metálicas - ano base 2015. Coord. Geral Wagner Fernandes Pinheiro, Osvaldo Barbosa Ferreira Filho, Carlos Augusto Ramos Neves; Equipe Técnica por Marina Marques Dalla Costa...[et. Al.]; -Brasília, 40 p. Disponível em: http://www.dnpm.gov.br/dnpm/publicacoes/serieestatisticas-e-economia-mineral/anuario-mineral/anuario-mineralbrasileiro/anuario-mineral-brasileiro-2016-metalicos

FERENCZI, P.A. (2001). Iron ore, manganese and bauxite deposits of the Northern Territory: Northern Territory Geological Survey, Report B, p. 63-89.

FUNDAÇÃO ESTADUAL DO MEIO AMBIENTE - FEAM (2016), Inventário de resíduos sólidos da mineração: Ano-base 2015. Belo Horizonte, MG: Feam 48 p. Disponível em:http://www.feam.br/images/stories/2017/RESIDUOS/Inventario_Res\%C3\%A Ddu os_S\%C3\%B3lidos_Miner\%C3\%A1rios_2016_Rev1_COM_FICHA.pdf

FOURIE A. B. (1999) The selection of sites for metalliferrous, diamond and coal residue deposits, Design of mine waste disposal systems. (ed. By G.E. Blight) (University of Witwatersrand, Johannesburg, South Africa, 14 - 18 September, 1999), 25-32.

FOURIE, A.B.; BLIGHT, G.E.; PAPAGEORGIU, G. (2001) Static Liquefaction as a possible explanation for the Merriespruit tailings dam failure. Canadian Geotechnical Journal; 38(4):707-719.

GORE, M.S. (2015), Geotechnical Characterization of Bauxite Residue (Red Mud), Doctoral Dissertation, The University Texas at Austin, 307 p.

GRUBB, P.L.C. (1973) Genesis of bauxite deposits in the Lower Amazon basin and Guiana coastal plain. Economic Geology 74 (4), pp 735-750.

HARRASSOWITZ, H. L (1926) Laterit; Material und Versuch erdgeschichtlicher Auswertung - Berlin : Gebrüder Borntraeger

HOSE, H. R. (1960): The genesis of bauxites, the ores of aluminium. Proc. Int. Geol. Congress, XXI. Section. Part X VI Copenhagen pp 23-747

IWASAKI, I. (1986). Soil liquefaction studies. In Japan: state-of-the-art. Soil Dynamics and Earthquake Engineering, 1986, Vol. 5, No. 1. pp. 1-67.

KIRPAL, G.R.(1973). Economic types os bauxites in the USSR and regularities of their distribution and formation. In: The International Committee for Study of Bauxite, Alumina \& Aluminium (ICSOBA) Nice, 1973. Proceedings p. 31-35. 
KLEIN C. \& HURLBUT JR. C.S. (2003) Manual of Mineralogy, basado en la obra de Dana, Vol 2, 4ed. Barcelona, Editorial Reverté.

KLOHN, E.J. (1982). Tailing Dam Design, Seminar on Geotechnical aspects of Mine Design and Tailings Containment, Edmonton. P.1-53.

KOTSCHOUBEY B. (1988) Geologia do Alumínio In: Carlos Schobbenhaus e Carlos Eduardo Silva Coelho. (Orgs.). Principais depósitos minerais do Brasil, 1. ed. Brasilia. Ministério das Minas e Energia, Departamento Nacional da Produção Mineral e Companhia Vale do Rio Doce. v.3, p 599-619.

KOTSCHOUBEY, B.; CALAF, J.M.C.; LOBATO, A.C.C. LEITE, A.S. \& AZEVEDO, C.H.D. (2006) - Caracterização e gênese dos depósitos de Bauxita da província Bauxitífera de Paragominas, Noroeste da Bacia do Grajaú, nordeste do Pará/Oeste do Maranhão. - In: MARINI, O.J.; QUEIROZ, E.T.; RAMOS, B.W. (Eds) Caracterização dos depósitos Minerais em Distritos Mineiros da Amazônia, ADIMB - Brasília: pp 691-782.

LAMBE, T. W.; WHITMAN, R. V. (1979). Soil Mechanics, New York, John Wiley.

LI, L.Y. (1998), Properties of red mud tailings produced under varying process conditions. J. Environmental Engrg. 124 (3): 254-264.

LELONG, F.; TARDY, Y.; GRANDIM, G.; TRESCASES, J.J. \& BOULANGE, B. (1976) Pedogenesis, chemical weathering and processes of formation of some supergene ore deposits. In: Wolf, K.H. (Ed.). Handbook of strata-bound and stratiform ore deposits., Amsterdam. Elsevier. v.3, p 93-173.

LOPES, L.M. (1987). A evolução mineralógica, micromorfológica e química da bauxita e materiais correlatos da região Mirai, MG. Dissertação. Instituto de Geociências, Universidade de São Paulo. 120p.

LOPES R.F.; BRANQUINHO J.A. (1988). Jazidas de bauxita da zonada Mata de Minas Gerais. In: Schobbenhaus C. \& Coelho C.E.S. (eds). Principais depósitos minerais do Brasil: metaisbásicos, não-ferrosos, ouro e alumínio. Brasília, DNPM. V3, p.655-659.

LOPES, L .M.; CARVALHO. A. (1990). Gênese da bauxita de Miraí. Revista Brasileira de Geociencias, v. 19, n.4, p. 462-469.

LUMLEY, R.N. (2011), Introduction to aluminium metallurgy. In: Lumley R.N. (ed) Fundamentals of aluminium metallurgy: Production, processing and applications. (pp. 1-18).1ed. Cornwall, UK: Woodhead Publishing

MELFI, A.J. (1997), Brazilian Bauxite Deposits: A review. In: Carvalho A., Boulangé B., Melfi A.J., Lucas I. (eds). Brazilian Bauxites USP, FAPESP, Paris ORSTOM, Brazilian Bauxites. p 3-22.

MELFI, A.J.; CARVALHO, A (1984) - Bauxitization of alkaline rocks in Southern Brazil. (kaolinization) Sciences géologiques: Mémoire 73:161-172.

MELLO, L. G.; CARDOSO, W.S.; CARRIER, W. D. (1987) - Deposição dos rejeitos de lavagem de bauxita de Trombetas nas próprias áreas anteriormente lavradas. In I REGEO, anais, 1987, vol 1, p. 112 - 132.

MELLO, L. G.; SILVEIRA, A. A. (1991) - Leis de compressibilidade e permeabilidade de rejeitos brasileiros. In II REGEO, anais...Rio de Janeiro, vol 1, p. 167 - 76.

MELLO, L. G.; CARRIER III, D. \& LAPA, R. (1991) - Comportamento de reservatórios de rejeitos diluídos de bauxita. In II REGEO, anais... Rio de Janeiro, vol 1, p. 99107.

MARTIRES, R.A.C.(2009) Mineração de metais não ferrosos - Alumínio. In: Rodrigues A.F.(Coord.) Economia mineral do Brasil. Brasília-DF:DNPM, p 179-197. http://www.dnpm.gov.br/dnpm/publicacoes/serie-estatisticas-e-economiamineral/outras-publicacoes-1/4-1-aluminio 
MONKUL, M. M. and YAMAMURO, J. A. (2011). Influence of silt size and content on liquefaction behavior of sands. Canadian Geotechnical Journal; 48(6):931-942.

NIKRAZ, H.R., BODLEY, A.J., COOLING, D.J., KONG, P.Y.L., AND SOOMRO, M. (2007), Comparison of physical properties between treated and untreated bauxite residue mud. J. of Materials in Civil Engrg.19 (1): 2-9.

NEWSON, T., DYER, T., ADAM, C., AND SHARP, S., (2006), Effect of structure on the geotechnical properties of bauxite residue. J. Geotechnical \& Geoenvironmental Engrg. 123 (2): 143-151.

NORSK HYDRO ASA (2012). Aluminium Environment and Society. http://www.hydro.com/globalassets/1-english/aboutaluminium/files/aluminium _environment-and-society.pdf

NOCE, C.M.; ROMANO, A.W; PINHEIRO C.M.; MOL V.S.; SOARES A.C.P. (2012) Folha de Ubá 1:100.000 - SF.23-X-D-II. In: Soares A.C.P; Noce, C.M.; Trouw, R.A.J.; Heilbron, M.(Coords) Projeto Sul de Minas, Etapa I. Belo HorizonteMG:COMIG. http://www.portalgeologia.com.br/index.php/mapa/

OLIVEIRA FILHO, W. L. D.; ABRÃO, P. (2015), Disposição de Rejeitos de Mineração. In: Lázaro Zuquette. (Org.). Geotecnia Ambiental. 1ed.Sao Paulo: ELSEVIER, v. 1, p. 263-306.

PAREKH, B.; GOLDBERGER, W. (1976), An Assessment of Technology for Possible Utilization of Bayer Process Muds. Ohio, United States. EPA-600/2-76-301

PAZ, S. P. A. (2016). Desenvolvimento e otimização de métodos de controle de qualidade e de processo de beneficiamento para bauxitas gibbsíticas tipoParagominas. Tese de Doutorado, Escola Politécnica, Universidade de São Paulo, São Paulo. 205 p.

PATTERSON, S. H. (1967) Bauxite reserves and potential aluminium resources of the world. U.S. Geol. Surv. Bull. Washington 1228 p.176.

PAJOVIĆ, M., 2009, Genesis and genetic types of karst bauxites: Iranian Journal of Earth Sciences, v. 1, p. 44-56.

PEREIRA, E. L. (2005) Estudo do Potencial de Liquefação de Rejeitos de Minério de Ferro sob Carregamento Estático, Dissertação de Mestrado, Programa de PósGraduação em Engenharia Civil, Escola de Minas, Universidade Federal de Ouro Preto, $185 \mathrm{p}$.

POWER G.; GRÄFE M.; KLAUBER C. (2009). Review of current bauxite residue management, disposal and storage: Practices, Engineering and Science. CSIRO document DMR-3608, May 2009.

RACHEL, R. M. SILVA, F. C AND VAN DEURSEN, C. (2012). Reasons For Bauxite Beneficiation. The International Committee for Study of Bauxite, Alumina \& Aluminium - 30 October 2012 at ICSOBA-Belem.

Gangadhara Reddy 1 and B. Hanumantha Rao 2 "Evaluation of the Compaction Characteristics of Untreated and Treated Red Mud N.". (2016). 23-32.

RETALLAK, G.J., 2010, Laterization and bauxitization events. Economic Geology, v. 105, p. 655-667

RIBEIRO, L.F.M. (2000). Simulação física do processo de formação dos aterros hidráulicos aplicados a barragens de rejeitos. Tese de Doutorado, Universidade de Brasília, $235 \mathrm{p}$.

ROMANO, A. W.; CASTAÑEDA, C. (2006), A Tectônica distensiva pós-mesozoica na origem dos depósitos de bauxita da Zona da Mata mineira. Revista Geonomos, v.14 n.1 
ROUT, S.K., SAHOO, T., AND DAS, S.K. (2013), Design of tailing dam using red mud. Central European J. Engrg. 3(2): 316-328.

SANTOS, W. M. (2011), Mineralogia e geoquímica da bauxita derivada do anortosito, Barro Alto (Goiás). Dissertação. Instituto de Geociências, Universidade de Brasilia. p 186.

SARSBY, R.W. (2013) Tailings Dams In: Environmental Geotechnics, 2nd edition: ICE Publishing; 496p.

SGARBI, G.N.C. (2012). Rochas sedimentares. In: Geraldo N. Chaves Sgarbi (Org.). Petrografia macroscópica das rochas ígneas, sedimentares e metamórficas. 2ed. Belo horizonte: UFMG, p. 293-494.

SILVA, V.M. (2015). Análise de sensibilidade das estimativas ao erro amostral, posicional e suas aplicações. Dissertação. Programa de Pós-Graduação em Engenharia de Minas, Metalúrgica e de Materiais. Universidade Federal do Rio Grande do Sul.

SIGOLO, J.B. (1979). Geologia dos depósitos residuais bauxiticos de Lavrinhas, SP e sua viabilidade econômica. Dissertação de Mestrado, Instituto de Geociências. da Universidade de São Paulo, 190p.

SCHULTE, R.F., \& FOLEY, N.K. (2014). Compilation of gallium resource data for bauxite deposits: U.S. Geological Survey Open-File Report 2013-1272, 14 p., 3 separate tables, http://dx.doi.org/10.3133/ofr20131272.

SOMOGYI, F. \& GRAY,D. (1977). Engineering properties affecting disposal of red muds. In Conference on Geotechnical Practice for Disposal of Solid Waste Materials. ASCE, Ann Arbor, Michigan: 1-22.

SKEMPTON, A.W. (1954). The pore pressure coefficients $A$ and B. Géotechnique, Vol. 4 , n. 4 , p. $143-147$.

STINSON, J. M. (2013) Correlation of Red Mud Consolidation with Its Soil Properties, in Essential Readings in Light Metals: Alumina and Bauxite, Volume 1 (eds D. Donaldson and B. E. Raahauge), John Wiley \& Sons, Inc., Hoboken, NJ, USA.

SUBRAT K. ROUT, S.K., SAHOO, T. \& DAS, S. K. (2013). Design of tailing dam using red mud. Cent. Eur. J. Eng. $\cdot 3(2) \cdot 2013 \cdot 316-328$.

TERZAGHI, K. PECK, R.B. \& MESRI, G. (1996) Soil Mechanics in Engineering Practice.

TSUCHIDA, H. (1970), Prediction and Countermeasure Against the Liquefaction in Sand Deposits," Abstract of the Seminar in the Port and Harbor Research Institute (in Japanese).

UNITED.STATES GEOLOGICAL SURVEY - USGS, 2017, Mineral commodity summaries 2017: U.S. Geological Survey, p 202. https:// doi.org/10.3133/7018019.

VADÁSZ, E. (1951). Bauxite Geology. Akadémiai Kiadó. Budapest p 127.

VALETON, I. (1972). Bauxites - Developments in soil Science 1, Netherlands, Elsevier. $226 p$.

VALETON, L, BEISSNER, H., CARVALHO, A. (1991) - The Tertiary bauxite belt on tectonic uplift areas in the Serra da Mantiqueira, South-East Brazil. In: Contributions to Sedimentology. H. Fuchtbauer, A. Lisitzin, J. D. Milliman and E. Seibold (eds.) E. Schweizerbart'sche Verlagsbuchhandlung, Stuttgart, p 1-99.

VARAJÃO, C.A.C. (1988) - Estudo comparativo das jazidas de bauxitas do Quadrilatero Ferrifero, MG. Micromorfologia, geoquimica, geomorfologia e sensoriamento remoto. Dissertação de Mestrado. Instituto de Geociências da Universidade de Sao Paulo, p.213.

VICK, S. G. (1983). Planning, design and analysis of tailings dams. Nova York: John Wiley. p. 382. 
VILLAR, L.F.S; CAMPO, T.M.P.; AZEVEDO, R.F. \& ZORNBERG, J.G. (2009). Influence of laboratory techniques on the geotechnical characterization of mining and industrial wastes. Proceedings of the 17th International Conference on Soil Mechanics and Geotechnical Engineering. M. Hamza et al. (Eds.). 186-189.

VILLAR, L.F.S. (2002) Estudo do adensamento e ressecamento de resíduos de mineração e processamento de bauxita. Tese (Doutorado em Engenharia Geotécnica) - Pontifícia Universidade Católica do Rio de Janeiro. 461p.

VAN DEURSEN, C. M. (2016) Métodos de desaguamento e disposição de rejeito da bauxita: estudo de caso e avaliação econômica. Dissertação (Mestrado em Engenharia Mineral) - Escola Politécnica, Universidade de São Paulo, São Paulo. 


\section{APÊNDICE}

Apêndice 01 - Fotografias dos corpos de prova cisalhados na câmara triaxial em todos os pontos de estudo sob diferentes tensões confinantes.

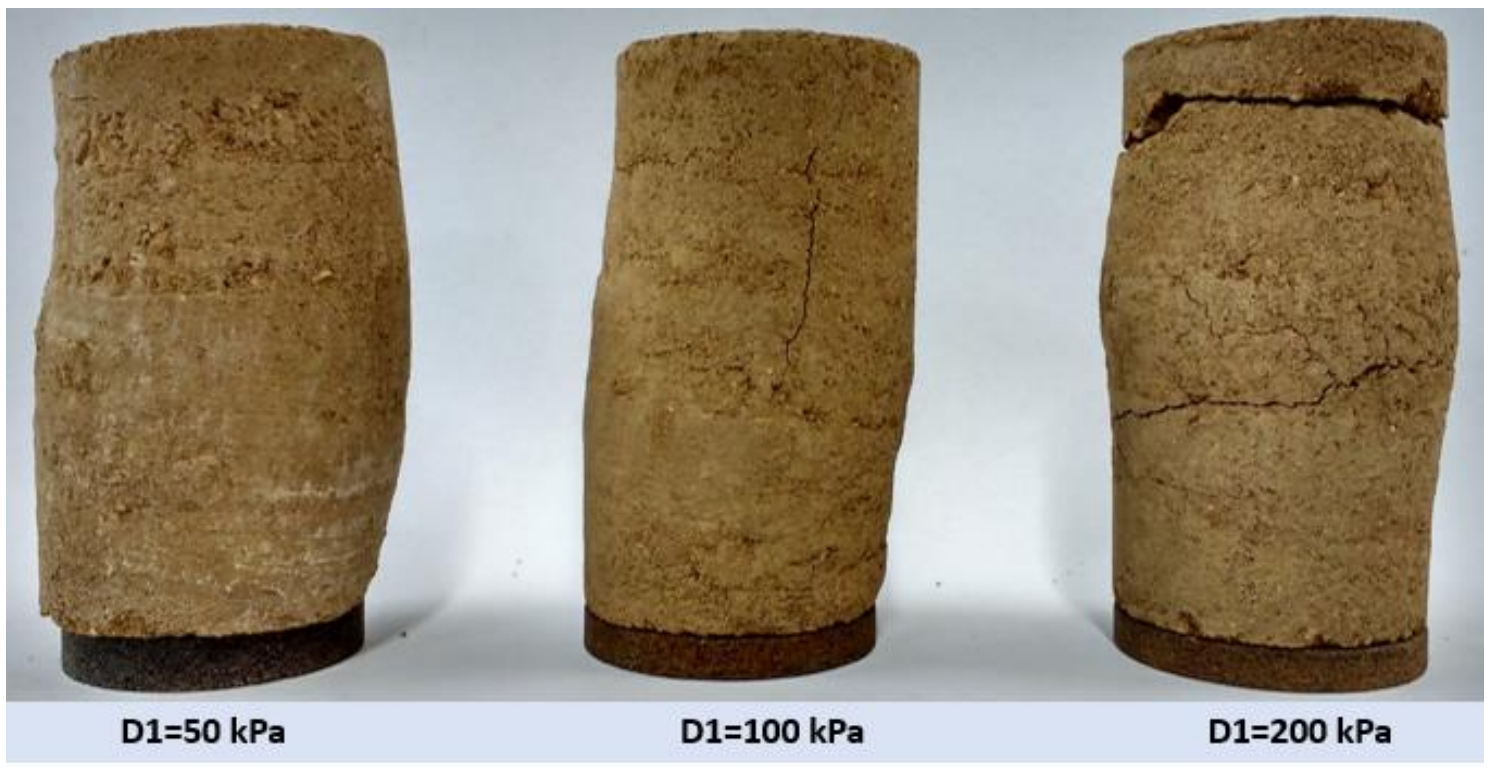

Figura 0-1- Corpos de prova ensaiados no ponto D1.

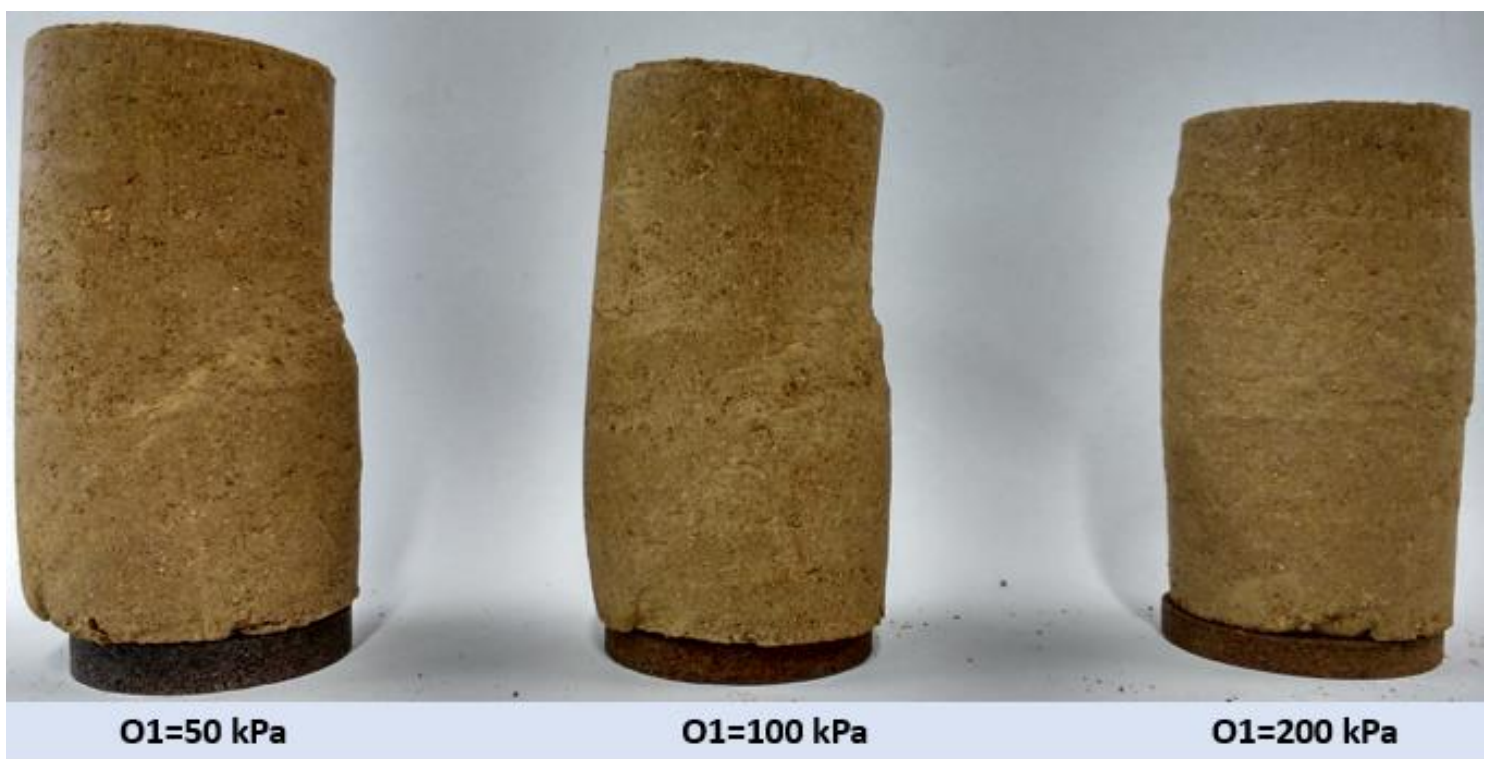

Figura 0-2 Corpos de prova ensaiados no ponto 01. 


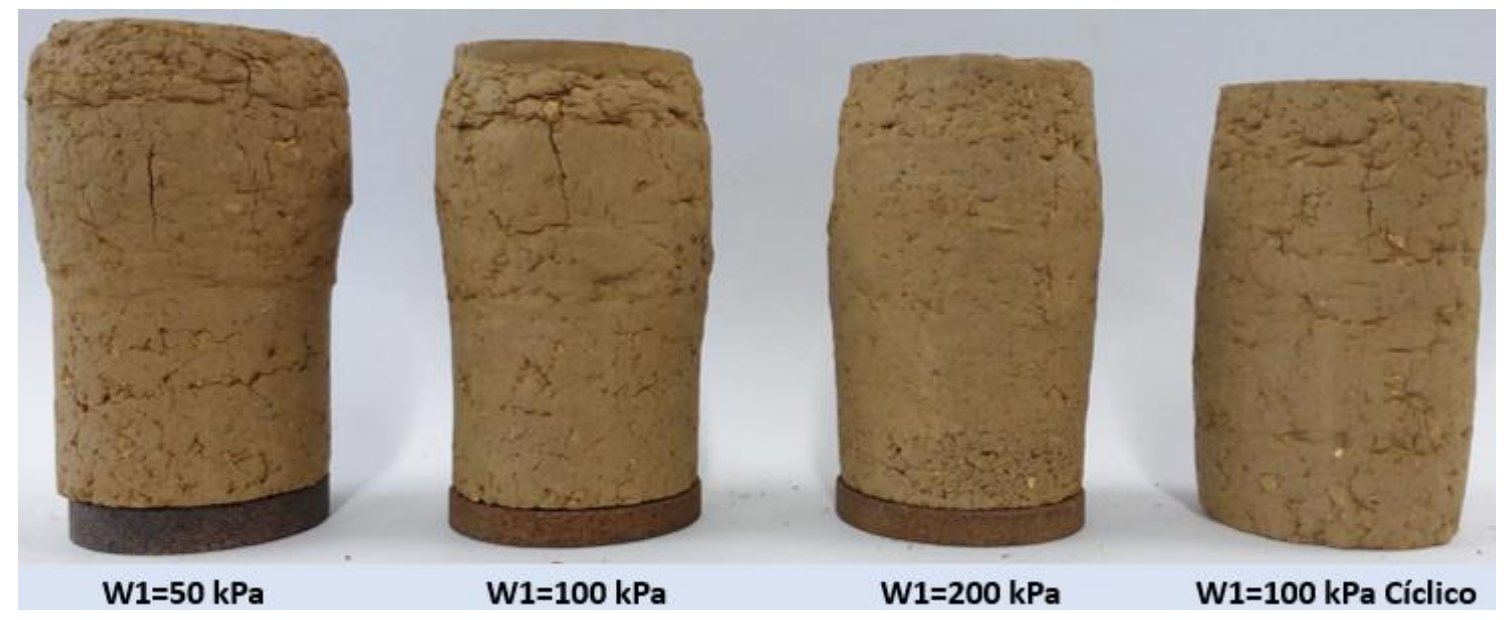

Figura 0-3 Corpos de prova ensaiados no ponto W1.

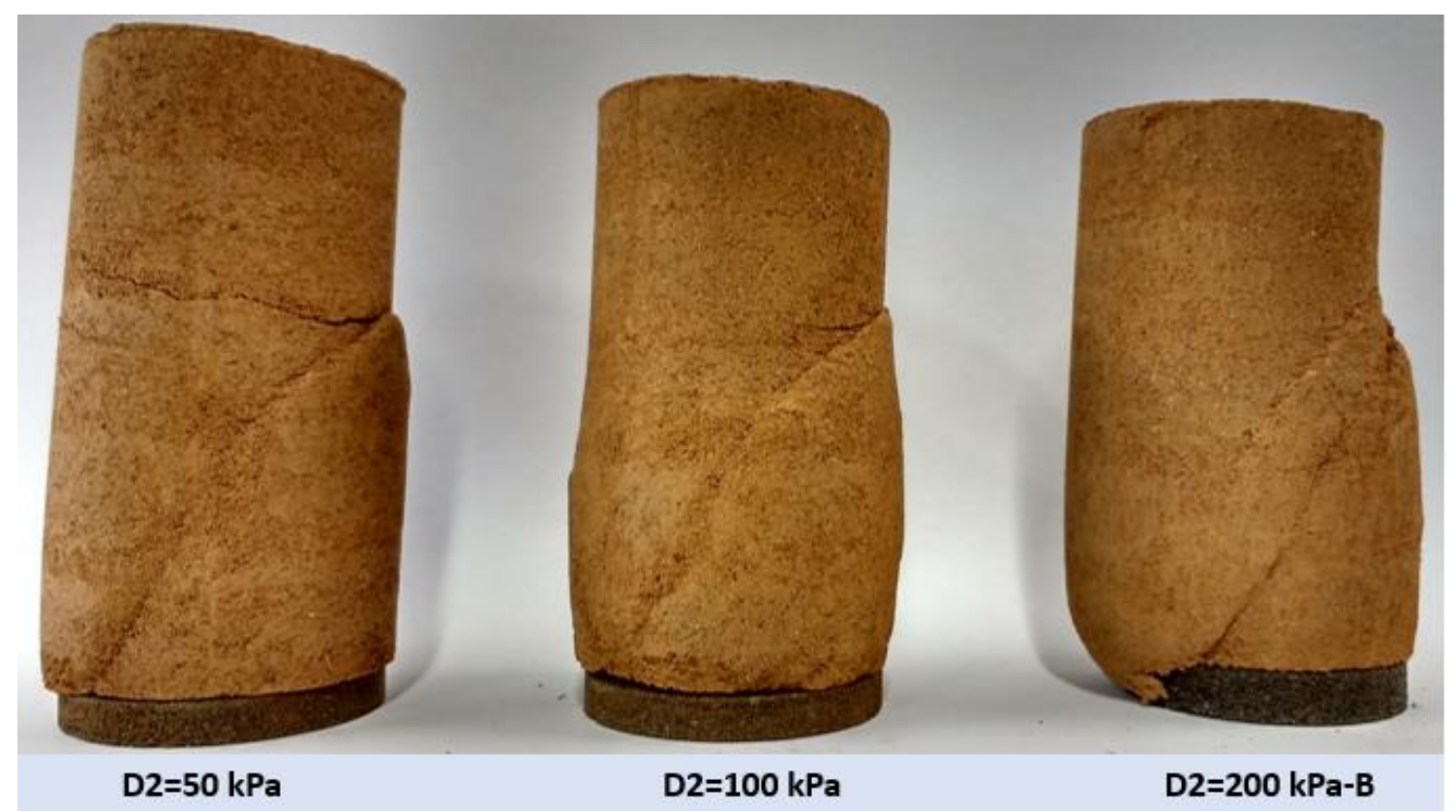

Figura 0-4 Corpos de prova ensaiados no ponto D2.

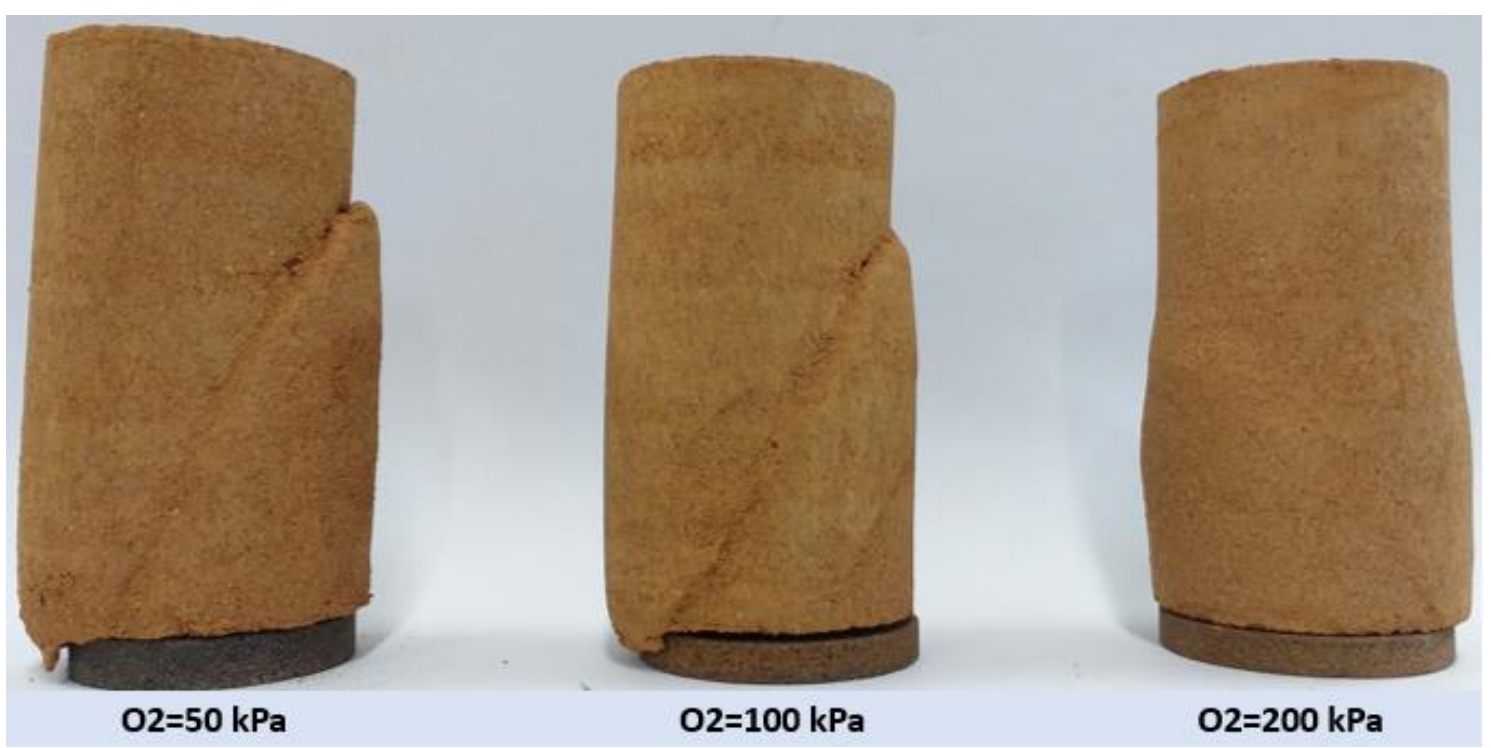

Figura 0-5 Corpos de prova ensaiados no ponto 02. 


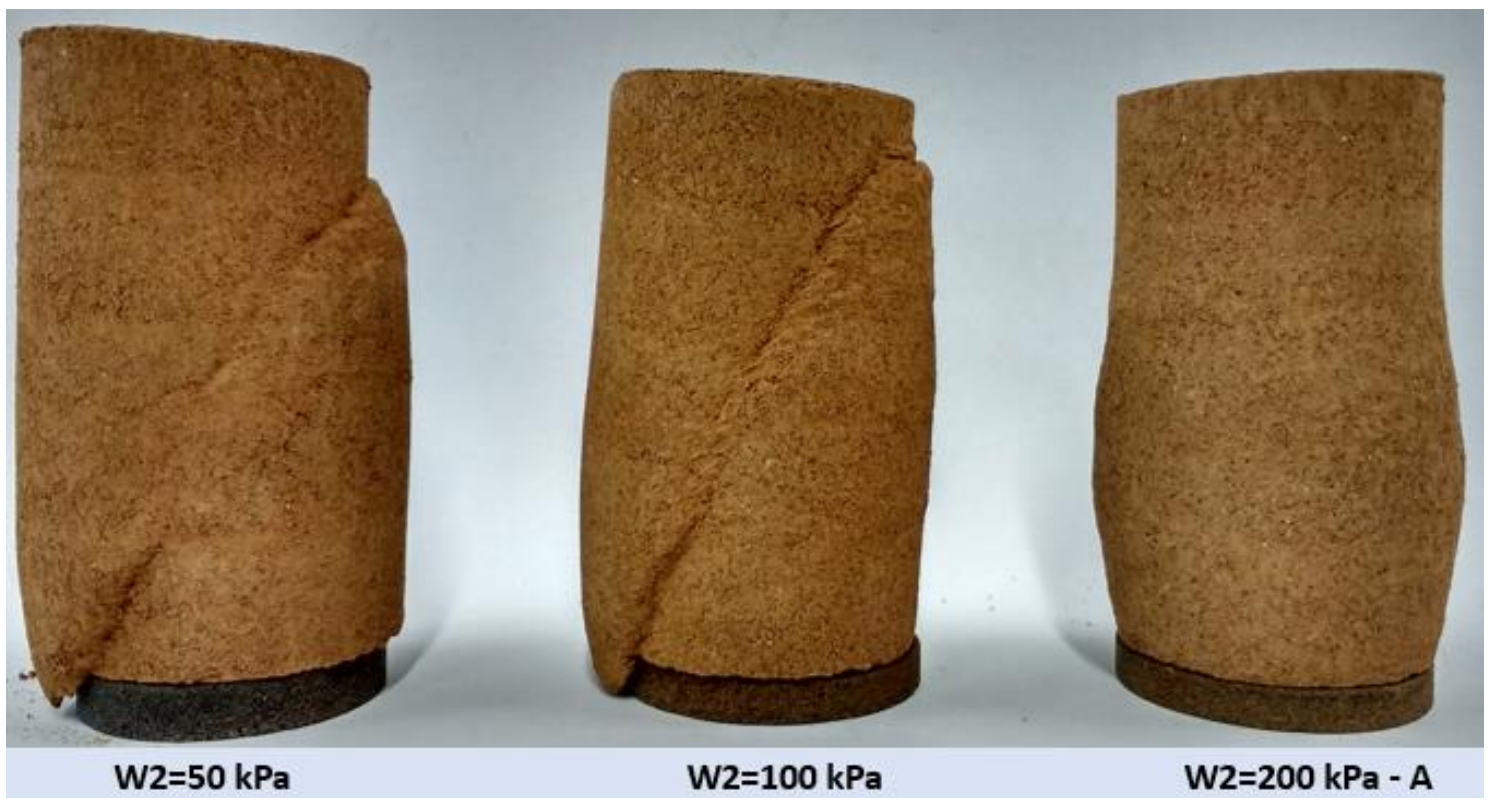

Figura 0-6 Corpos de prova ensaiados no ponto W2.

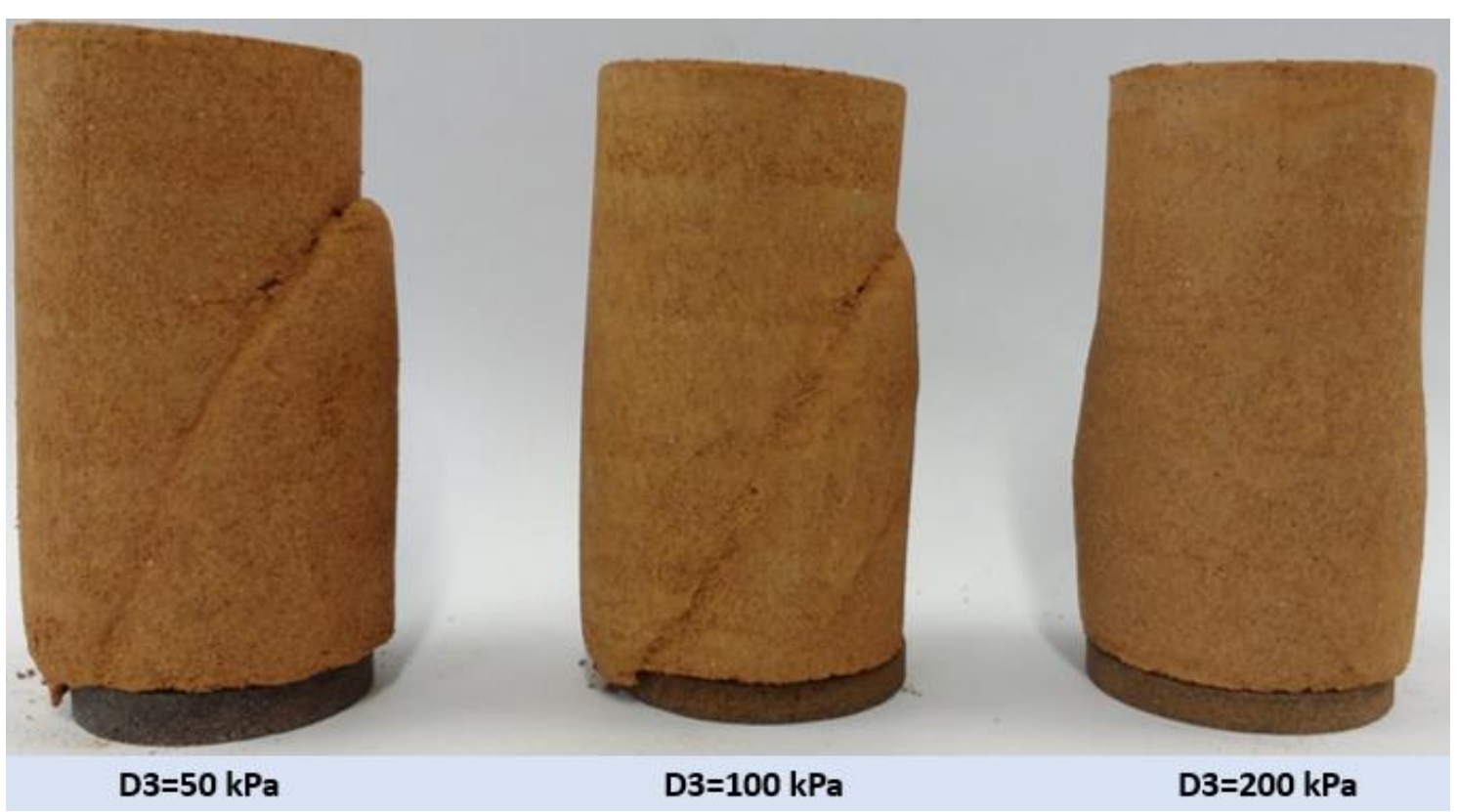

Figura 0-7 Corpos de prova ensaiados no ponto D3 


\title{
Apêndice 02 - Texto em formato de artigo a ser submetido no Congresso Internacional Tailings \& Mine Waste.
}

\section{Shear strength characteristics of bauxite waste from Brazil}

\author{
C. T. Palomino \\ Department of Mineral Resources and Hydrogeology, Institute of geology, University of São Paulo, \\ São Paulo, São Paulo, Brazil.
}

F. A. M. Marinho

University of São Paulo, São Paulo, São Paulo, Brazil.

\begin{abstract}
The global demand for metals has grown intensely. This commercial interest has increased the amount of waste produced in the extraction and/or processing of minerals from which metals are extracted. This increase in demand allows that areas less rich in mineral, be-come economically feasible, thus generating more tailing material. The disposal of the waste requires large tailings dams, which in turn require special care from geotechnical and environmental aspects. Thus, the use of waste as landfill construction material would minimize the volumes of tailings dams. To make the waste useable from a geotechnical point of view it is necessary to determine the geotechnical parameters involved with the application. One of the most important aspects are the shear strength. In this paper the geo-mechanical behavior of a waste of bauxite mining from Miraí mine, Minas Gerais-Brazil, is studied. The waste was characterized in terms of geotechnical nature, evaluating its behavior in some specific compaction conditions. The studies involved the determination of material behavior at CAU triaxial test. The aim of this study is to present the shear strength characteristics of the waste under different compaction conditions
\end{abstract}

\section{INTRODUCTION}

Brazil is the third largest bauxite producer in the world, with 34.5 million of tons per year. This production position generates a quantity of mining tailings that reach 14 million of tons per year (van Deursen, 2016). In general, the tailing has no economic value and is disposed in tailing dams. The use of mining tailings as landfill materials is an alternative to be consider to improve economic and environmental aspects of the production of aluminum. As mentioned by Power et al. (2011), the steady growth of bauxite tailings in the world requires that alternative uses of these materials be investigated. Klauber et al. (2011) present some suggestion to improve the use of bauxite tailing, but all of them is a low volume use, which may be different of a geotechnical use. In the specific case of bauxite red muds, the major problem is generally its high potential for contamination due to the chemical process the ore bauxite benefited is usually subjected. According to IAI (2008) the initial processing of bauxite is simple since requires only the removal of clay, which can be done by a simple washing, screening cycloning and sorting beneficiation process. In the case of the mine of Miraí, located at the state of Minas Gerais (Brazil), there is a separation of the ore prior to the application of the Bayer process. The Bayer process generates a waste with potential for contamination. The study presented in this paper has no potential for contamination, since no chemical were added to the materials. This separation process is not common in the bauxite processing industry. However, due to logistics aspects there is a previous beneficiation process, which generate the tailing used in this study.

The usual variability of the tailing can generate variation on the material geotechnical properties, which may create difficulties for its use. An effort should be made to reduce this variability. As a non-natural material, the tailing does not follow natural segregation and may 
present an unusual behavior even when compacted. For this reason, it is important to evaluate the behavior of that type of material and assess its variability. The geotechnical behavior of the bauxite tailing (most of them red mud) has been investigated by many researches under different aspects (e.g Fourie, 1988; Nikraz et al., 2007; Villar et al., 2009; Buchanan et al., 2010; Pedrosa, 2012; Rout et al., 2013; Gore, 2015). As described by Blight and Bentel (1983) and McRobert (2012) the deposition of tailing (in general) as a slurry form a beach which has its importance for the design of the tailing facilities, affecting the storage capacity, the tailing dam itself and the eventual cover when required. Although the use of any tailing material requires a specific process for collection and reduction of water content, the present study involved the material collected at the beach and then subjected to variations due to the process.

The use of mining tailings as a material for compacted embankments requires the investigation of several geotechnical aspects, ranging from grain size distribution to shear strength behavior under undrained conditions, its susceptibility to liquefaction and an evaluation of the its deformability.

\section{MATERIALS}

\subsection{The bauxite waste tested}

The material in study is a tailing from part of the process of beneficiation of lateritic bauxite from a mining beneficiation plant and mining area located at Miraí, at the state of Minas Gerais Brazil. A diagram for aluminium process is presented in Figure 1 showing from which part of the process the material was obtained. The process starts with grinding and crushing of the material followed by the washing and sieve separation. At this point, the bauxite ore goes for the Bayer process and the remaining of the material, at this plant, goes to the tailing dam.

According to Rachel et al. (2012) the brazilian bauxite ores presents a high amount of reactive silica, and an intermediate beneficiation plant has been introduced to reduce the amount of reactive silica before going to refinery. The material tested in the present experimental program is obtained from this washing process, as indicated in Figure 1.

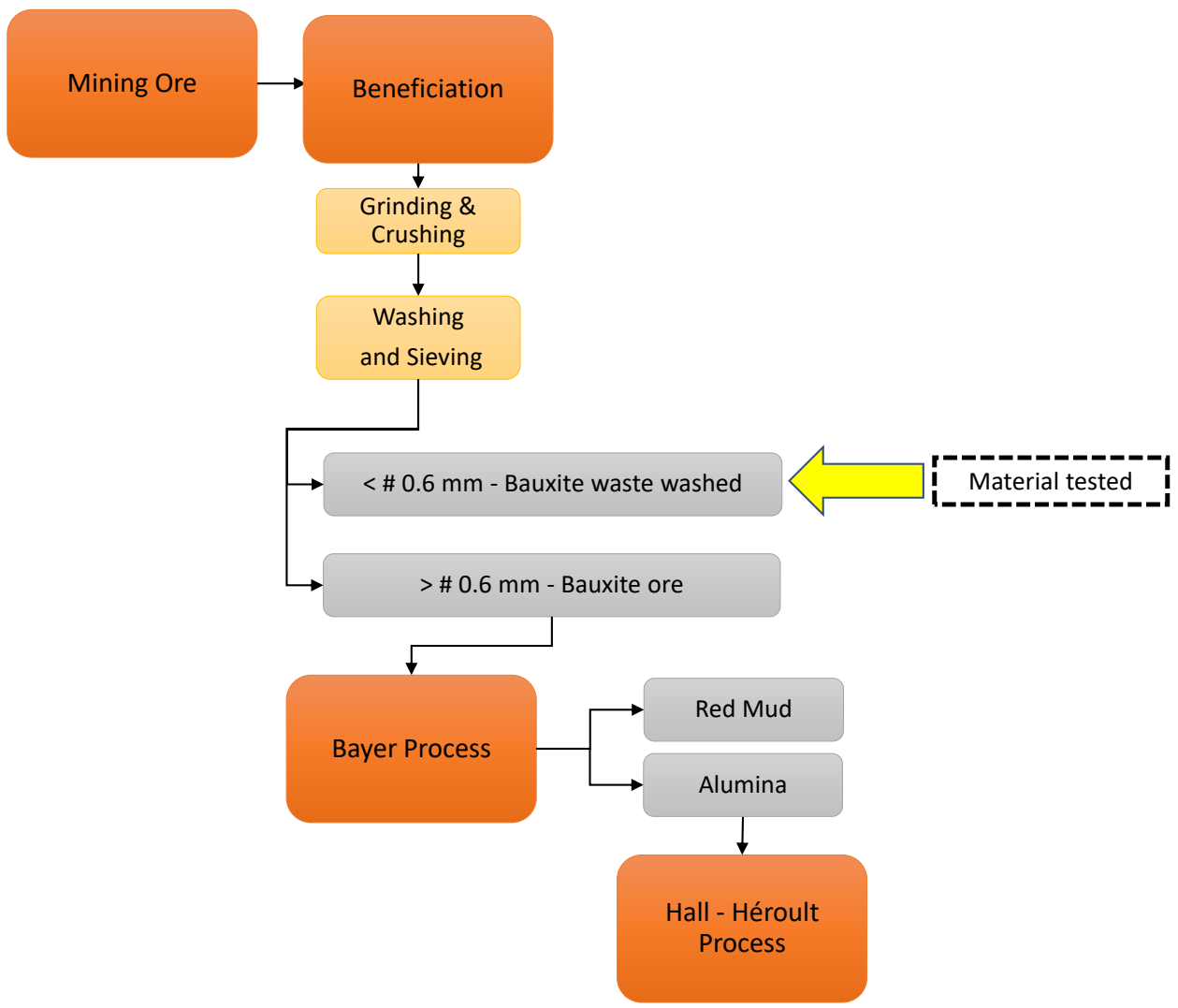

Figure 1. Conceptual Aluminum production process and the material tested. 
It is important to highlight that the characterized material differ strongly from the red mud. As described the tested material is a byproduct of mechanical processes of disaggregation without presence of chemicals. Although the process considers that only material finer than $0.6 \mathrm{~mm}$ is disposed into the tailing dam at Miraí, the actual material presents grains up to $10 \mathrm{~mm}$.

Two samples were collected from the beach of the tailing dam at Miraí site, both presenting a consistency of a slurry. These samples were collected in different months of 2016 at approximately $15 \mathrm{~m}$ of the discharge pipe. The first one denominated B-Mir01 was collected in $\mathrm{Feb} / 2016$, this sample weighted approximately $15 \mathrm{~kg}$. A second sample denominated B-Mir02 was collected in Sept/2016, this slurry weighted $25 \mathrm{~kg}$ was deposited in steel drum and was transported to the soil mechanic laboratory of São Paulo University, in São Paulo city. At the lab, the sample was homogenized and air dry for geotechnical characterization. The present paper shows the shear strength test results for samples B-Mir01 and B-Mir02.

\subsection{Geotechnical Characterization}

The geotechnical characterization of the material included grain size distribution, Atterberg limits and the determination of the compaction curve. The tests followed the ASTM standards.

The grain size distribution was performed using potassium hexa-metaphosphate as dispersion agent for grain lower than mesh 200. Figure 2 presents the grain size distribution curve for two samples of bauxite tailings collected at Miraí site. The grain size distribution of the bauxite ore is shown for comparison.

The sample B-Mir01 presented $38 \%$ of coarse-grained soils and $62 \%$ of fine-grained soils and a D60 $=0.070 \mathrm{~mm}$. The sample B-Mir02 presented $61.3 \%$ of coarse-grained and $37.7 \%$ of finegrained soils and $\mathrm{D} 60=0.16 \mathrm{~mm}$.

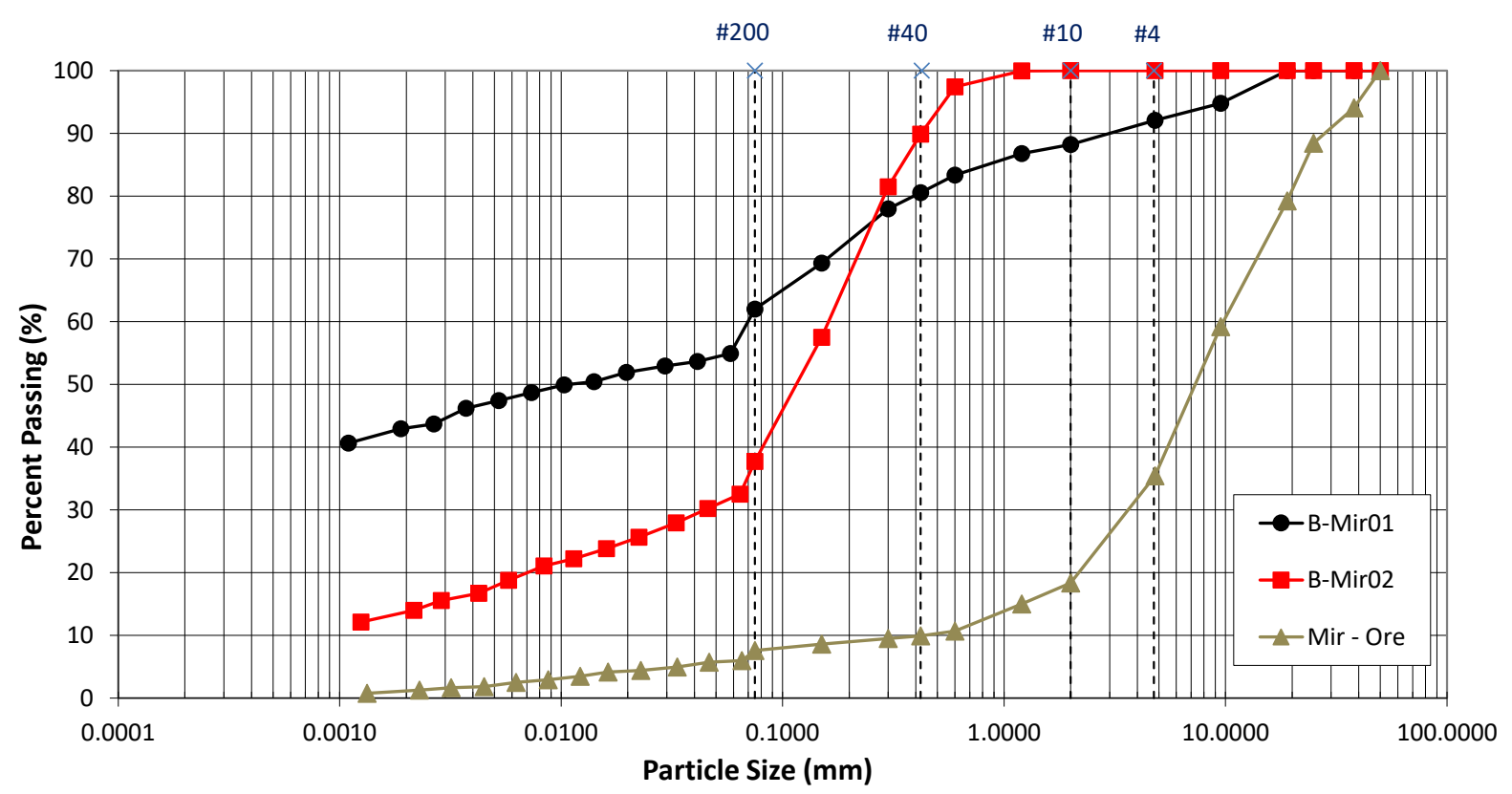

Figure 2. Grain size distribution of Miraí bauxite tailings.

The two samples presented different grain size distribution, although these materials were collected in the same place, yet in different moments. This difference is due to changes in the exploration areas when the required ore content is exhausted.

The bauxite ore presents $92.4 \%$ of coarse-grained soils and $7.6 \%$ of fine-grained soils, with an effective diameter (D10) of $0.42 \mathrm{~mm}$. The uniformity coefficient $\mathrm{Cu}=22.86$ and co-efficient of gradation $\mathrm{Cc}=3.21$.

Table 1 presents the characterization data for the two samples and the bauxite ore. 
Table 2. Materials Characteristics

\begin{tabular}{cccc}
\hline & B-Mir01 & B-Mir02 & Miraí-Ore \\
\hline$\%<2 \mu \mathrm{m}$ & 62 & 38.7 & 7.5 \\
Liquid Limit $\left(\mathrm{w}_{1}\right)$ & 44 & $\mathrm{NP}$ & $\mathrm{NP}$ \\
Plasticity Index $\left(\mathrm{I}_{\mathrm{P}}\right)$ & 18 & $\mathrm{NP}$ & $\mathrm{NP}$ \\
Specific gravity & 2.71 & 2.79 & 2.64 \\
$\mathrm{D}_{10}(\mathrm{~mm})$ & $<0.001$ & $<0.001$ & 0.004 \\
$\mathrm{D}_{50}(\mathrm{~mm})$ & 0.01 & 0.12 & 7 \\
$\mathrm{pH}$ & 4 & 5 & 5 \\
\hline
\end{tabular}

The compaction curve using standard Proctor energy for the two materials tested are shown in Figure 3, along with the location of the six points from where specimens were prepared for the triaxial tests. The points at which the specimens were prepared are labeled according to the position in relation to its respective compaction curve (e.g. D - dry of optimum, $\mathrm{O}$ - at optimum and $\mathrm{W}$ - wet of optimum). Table 2 presents the maximum dry density and optimum water content for the two materials.

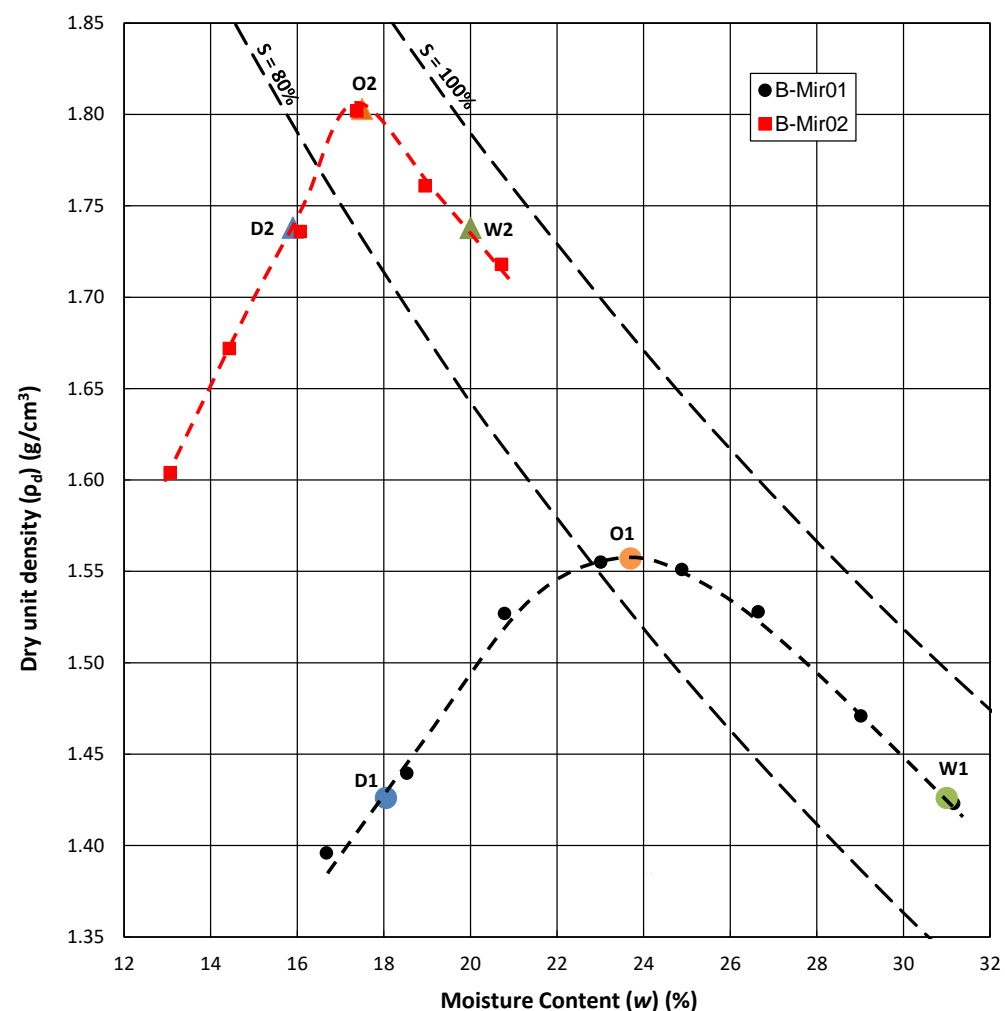

Figure 3. Compaction curve for B-Mir01 and B-Mir02 bauxite tailing and study points.

Table 3. Compaction Characteristics

\begin{tabular}{ccc}
\hline & B-Mir01 & B-Mir02 \\
\hline Máximum dry density $\left(\mathrm{g} / \mathrm{cm}^{3}\right)$ & 1.56 & 1.80 \\
Optimum water content $(\%)$ & 23.7 & 17.5 \\
\hline
\end{tabular}

\section{METHODS}

\subsection{Preparation of specimens}

Three specimens were prepared at each of the points shown in Figure 3. The specimens were statically compacted in five layers to reach the specific dry density using the defined water 
content. The material used to prepare the specimen was passed on No $4(4.75 \mathrm{~mm})$ sieve. A cylindrical tri-part split mold with $81 \mathrm{~mm}$ of height and $38 \mathrm{~mm}$ of diameter was used. Initial characteristics of 18 specimens tested are presented in Table 4

Table 4. Initial conditions of specimens for CAU triaxial test

\begin{tabular}{llllll}
\hline Taxonomy & $\sigma 3^{\prime}(\mathrm{kPa})$ & wi $(\%)$ & $\mathrm{Si}(\%)$ & $\mathrm{e}$ & $\rho \mathrm{d}\left(\mathrm{g} / \mathrm{cm}^{3}\right)$ \\
\hline D1-50 & 50 & 17.80 & 0.54 & 0.90 & 1.43 \\
D1-100 & 100 & 18.35 & 0.54 & 0.92 & 1.41 \\
D1-200 & 200 & 18.30 & 0.57 & 0.87 & 1.45 \\
O1-50 & 50 & 23.15 & 0.79 & 0.79 & 1.51 \\
O1-100 & 100 & 23.40 & 0.81 & 0.78 & 1.52 \\
O1-200 & 200 & 24.15 & 0.86 & 0.76 & 1.54 \\
W1-50 & 50 & 30.60 & 0.91 & 0.91 & 1.42 \\
W1-100 & 100 & 30.15 & 0.91 & 0.90 & 1.43 \\
W1-200 & 200 & 29.80 & 0.98 & 0.93 & 1.45 \\
D2-50 & 50 & 15.85 & 0.67 & 0.66 & 1.68 \\
D2-100 & 100 & 15.55 & 0.67 & 0.65 & 1.69 \\
D2-200 & 200 & 15.85 & 0.65 & 0.68 & 1.66 \\
O2-50 & 50 & 17.30 & 0.78 & 0.62 & 1.72 \\
O2-100 & 100 & 17.45 & 0.76 & 0.64 & 1.7 \\
O2-200 & 200 & 17.05 & 0.78 & 0.61 & 1.73 \\
W2-50 & 50 & 20.00 & 0.85 & 0.66 & 1.68 \\
W2-100 & 100 & 19.90 & 0.85 & 0.65 & 1.69 \\
W2-200 & 200 & 19.95 & 0.84 & 0.66 & 1.68 \\
\hline
\end{tabular}

\subsection{Triaxial CAU test}

Anisotropical consolidated undrained (CAU) triaxial tests were performed using a Bishop-Wesley triaxial cell with automatic control of the test and automatic data acquisition. All tests were performed under constant rate of deformation, using a rate of $1.8 \% /$ hour. Three sequential stages characterize the tests: Saturation, consolidation and shear.

The saturation procedure included a water flow to remove air from the back-pressure system lines, followed by a back-pressure application. The back pressure was increased at a rate of 60 $\mathrm{kPa}$ /hour until its value reached $490 \mathrm{kPa}$. The effective stress during saturation was kept in $10 \mathrm{kPa}$. At the end of the application of the back pressure the pore pressure parameter B was measured. Due to limitation of the pressure system the back pressure needed to be reduced to $100 \mathrm{kPa}$, keeping the effective stress at $10 \mathrm{kPa}$, prior the consolidation. A rate of back pressure reduction of $25 \mathrm{kPa} / \mathrm{min}$ was used during this procedure.

Table 5 presents the B value of all specimens and the values of the deviatoric stress at failure at peak and after peak with the corresponding axial strain. Attempts were made to try to in-crease the B value for the specimens compacted at the B-Mir01 dry points, the values for that specimen varied from 0.70 to 0.78 .

All specimens were anisotropically consolidated using a relation between axial and lateral stress of 0.7. Each specimen was consolidated to the designated effective stress, allowing drainage from the base of the specimen. The rate of loading was regulated according to the monitoring the pore water pressure at the top to avoid the development of excess of pore water pressure. The shear stage was performed under constant confining stress using a strain rate of $1.8 \%$ /hour.

\section{RESULTS}

\subsection{CAU triaxial test}

Due to limitation of space the stress-strain curves are not shown. The Mohr-Coulomb failure criterion was used to interpret the results. The tests were performed to axial strain between $8 \%$ to $16 \%$. Table 5 presents the value of the deviatoric stress at failure, the post-peak value and the 
corresponding axial strain for each specimen tested. For some specimen the post peak axial strain were not registered due to the negative pore water pressure development.

Table 5. Pore-water pressure parameter (B) and information at failure for all specimens

\begin{tabular}{lccccc}
\hline Specimen & $\mathrm{B}$ & $\mathrm{q}_{\mathrm{f}}=\left(\sigma_{1}^{\prime}-\sigma_{3}^{\prime}\right)_{\mathrm{f}}(\mathrm{kPa})$ & $\varepsilon_{\mathrm{a}-\mathrm{f}}(\%)$ & $\begin{array}{c}\mathrm{q}_{\mathrm{pp}} \\
(\mathrm{kPa})\end{array}$ & $\varepsilon_{\mathrm{a}-\mathrm{pp}}(\%)$ \\
\hline D1-50 & 0.74 & 126.0 & 0.856 & 117.0 & 1.968 \\
D1-100 & 0.78 & 189.5 & 2.068 & 163.0 & 5.962 \\
D1-200 & 0.70 & 299.2 & 1.581 & 244.7 & 6.037 \\
O1-50 & 0.96 & 213.8 & 1.445 & - & - \\
O1-100 & 0.95 & 319.4 & 1.374 & - & - \\
O1-200 & 0.97 & - & - & - & - \\
W1-50 & 0.98 & - & - & - & - \\
W1-100 & 0.97 & - & - & - & - \\
W1-200 & 0.98 & - & - & - & 3.987 \\
D2-50 & 0.90 & 300.5 & 1.993 & 264.2 & 6.004 \\
D2-100 & 0.92 & 456.7 & 1.753 & 409.2 & 8.009 \\
D2-200 & 0.90 & 726.9 & 2.724 & 670.0 & 5.985 \\
O2-50 & 0.93 & 412.7 & 2.578 & 334.3 & 6.053 \\
O2-100 & 0.95 & 588.0 & 3.572 & 491.1 & 6.010 \\
O2-200 & 0.96 & 795.1 & 4.974 & 773.7 & - \\
W2-50 & 0.96 & 394.0 & 3.587 & - & - \\
W2-100 & 0.96 & 508.6 & 4.310 & - & - \\
W2-200 & 0.96 & 687.2 & 7.712 & - & \\
\hline
\end{tabular}

Figures 4 and 5 presents the effective stress paths of the tests performed with the two samples (BMir01 and B-Mir02). The first point of all stress paths represents the initial stress state for the specimen at the end of the consolidation stage (using $\mathrm{K}=0.7$ ). The effective stress path envelope was defined from results obtained using the maximum normalized stress.

Figure 4 shows the stress paths for each compaction condition of the sample B-Mir01. In Figure 4a the results of the specimen compacted dry of the optimum is presented. After reaching the failure envelope, the material presented a high development of positive pore water pressure (PWP). This behavior may be related to fabric and initial void ratio. Figure $4 \mathrm{~b}$ shows stress path of the specimens prepared at optimum water content and maximum dry density. The behavior is different from the one observed with the specimen prepared at point D1 (see Figure 3). Positive PWP development was small at the beginning of the test and at the failure the material presented a dilatant behavior. For the specimens prepared above optimum (see Figure 3) the behavior was like the one observed for the material prepared dry of optimum in terms of PWP development. However, in figure 4c, it was observed a sudden PWP development, far from the failure envelope, suggesting a potential liquefaction phenomenon. Once the envelope was reached all specimens experienced a reduction in the PWP, increasing the strength. 

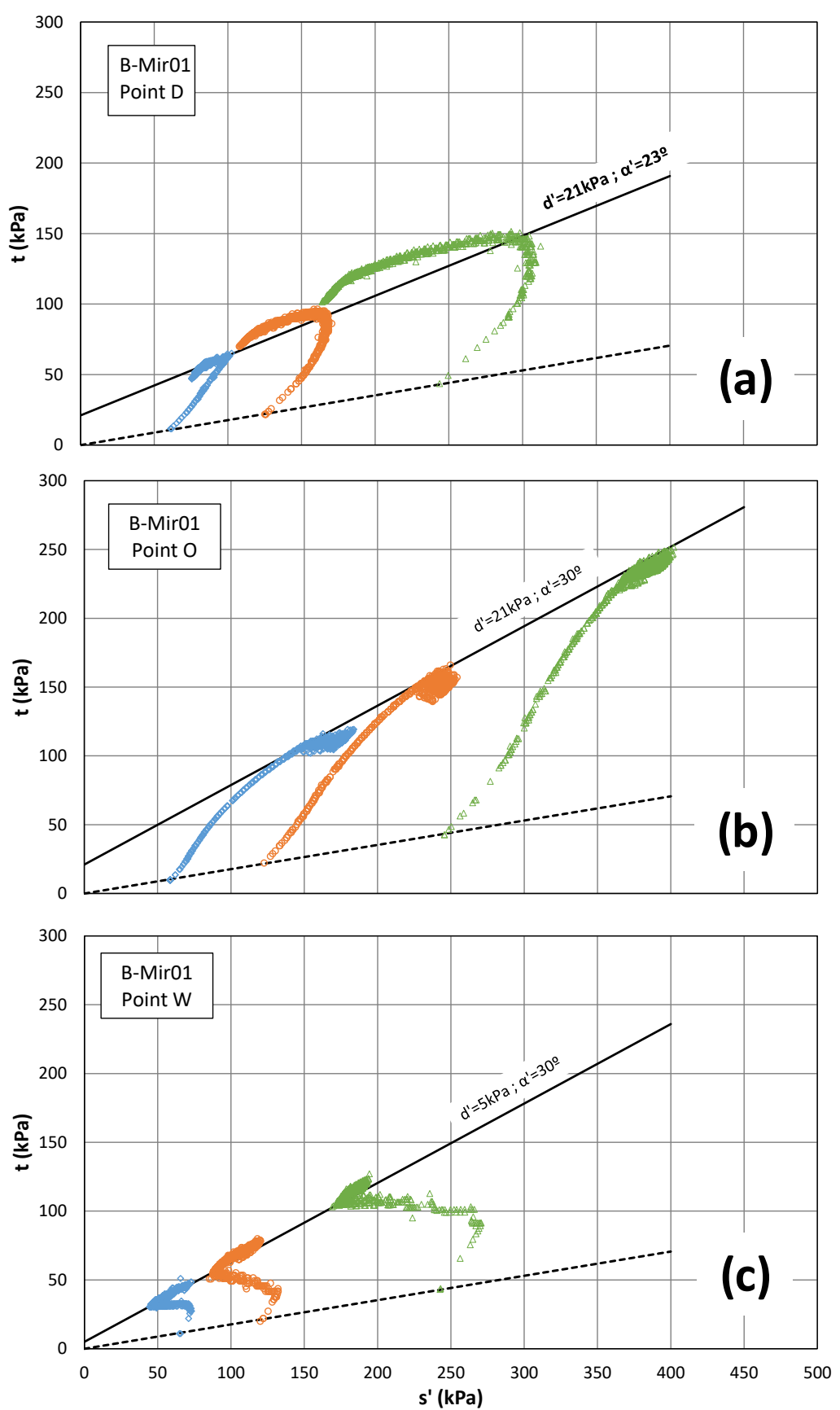

Figure 4. Effective stress paths for specimens of sample B-Mir01. (a) Point "D", (b) Point "O", (c) Point "W".

The specimens from the sample B-Mir02 did not developed significant PWP and did not shown differences between the compactions points (D, O and W). Figure 5 presents thee stress path of all specimens. The positive PWP development occurs only up to about $1 \%$ of axial strain, after that only negative PWP was observed. 

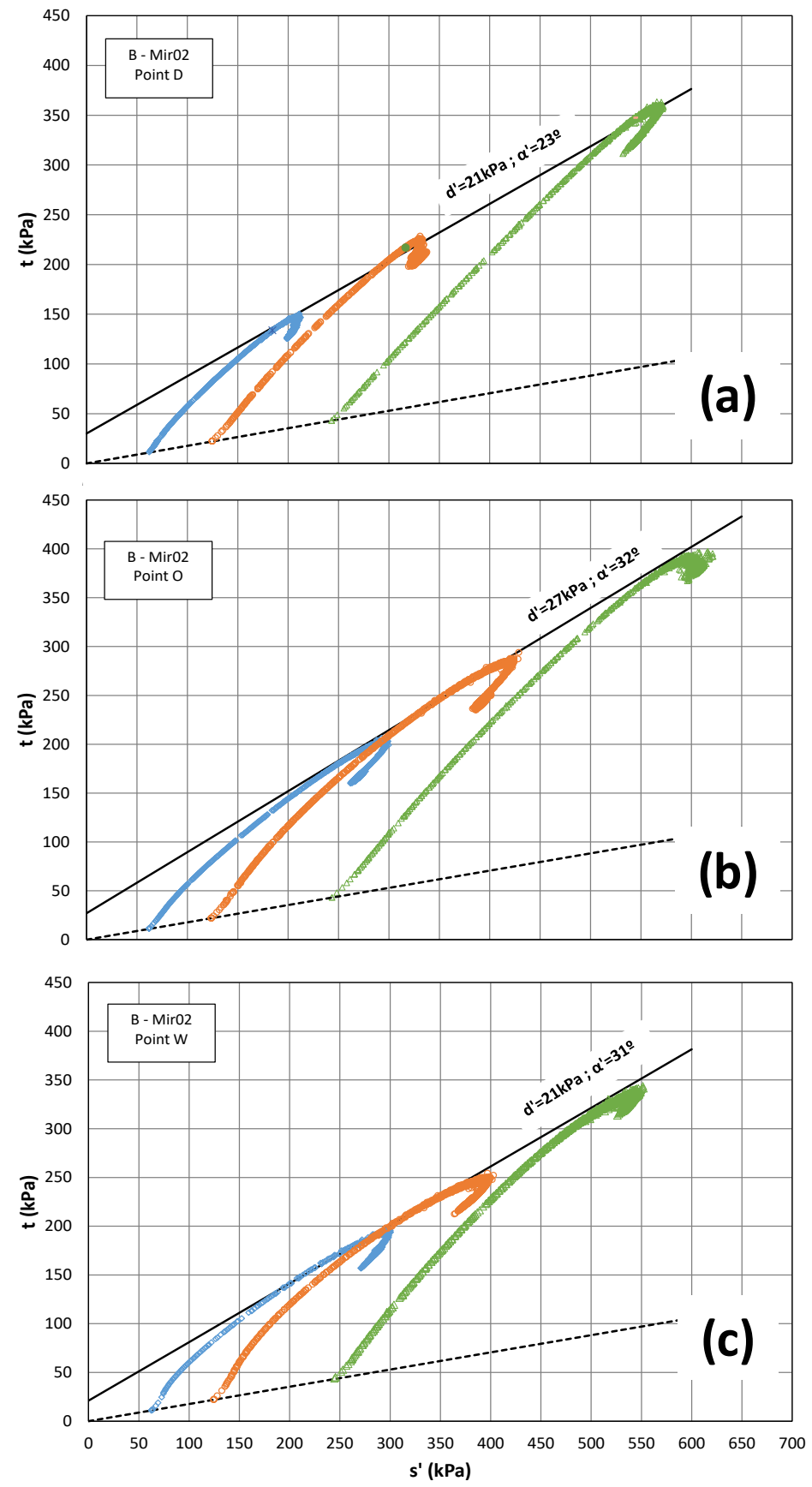

Figure 5. Effective stress paths for specimens of sample B-Mir02. (a) Point "D", (b) Point "O", (c) Point "W".

Table 6 presents the effective stress parameters for the material testes. The cohesion sample BMir01 was smaller than the cohesion for the B-Mir02. Considering the plasticity of the samples, this was not expected. The friction angle for the B-Mir02 was greater than for the B-Mir01, as expected.

Table 6 - Shear strength envelopes

\begin{tabular}{llcc}
\hline Sample & Compaction condition & c' $^{\prime}(\mathrm{kPa})$ & ${ }^{\prime}\left({ }^{\circ}\right)$ \\
\hline \multirow{3}{*}{ B-Mir01 } & Dry & 23 & 25 \\
\cline { 2 - 4 } & Optimum & 24 & 35 \\
\cline { 2 - 4 } & Wet & 6 & 35 \\
\hline \multirow{3}{*}{ B-Mir02 } & Dry & 35 & 35 \\
\cline { 2 - 4 } & Optimum & 32 & 39 \\
\cline { 2 - 4 } & Wet & 24 & 37
\end{tabular}


Figure $6 \mathrm{a}$ and $6 \mathrm{~b}$ show a normalized young modulus for the two samples prepared at the conditions shown in Figure 3. An attempt was made to present the modulus for strains smaller than $0.1 \%$, but some variability is observed to the external measurement of displacement.

It can also be observed, with some interpretation, that for small deformations, between 0.01 to $0.1 \%$, the value of the normalized young modulus varied between 800 and 1400 for the sample B-Mir01 and from 600 to 1400 for sample B-Mir02. The data from sample B-Mir02 presented more variability. The normalized modulus at a deformation of $0.1 \%$ was similar for both samples, with a slightly tendency for the sample B-Mir01 to give higher values

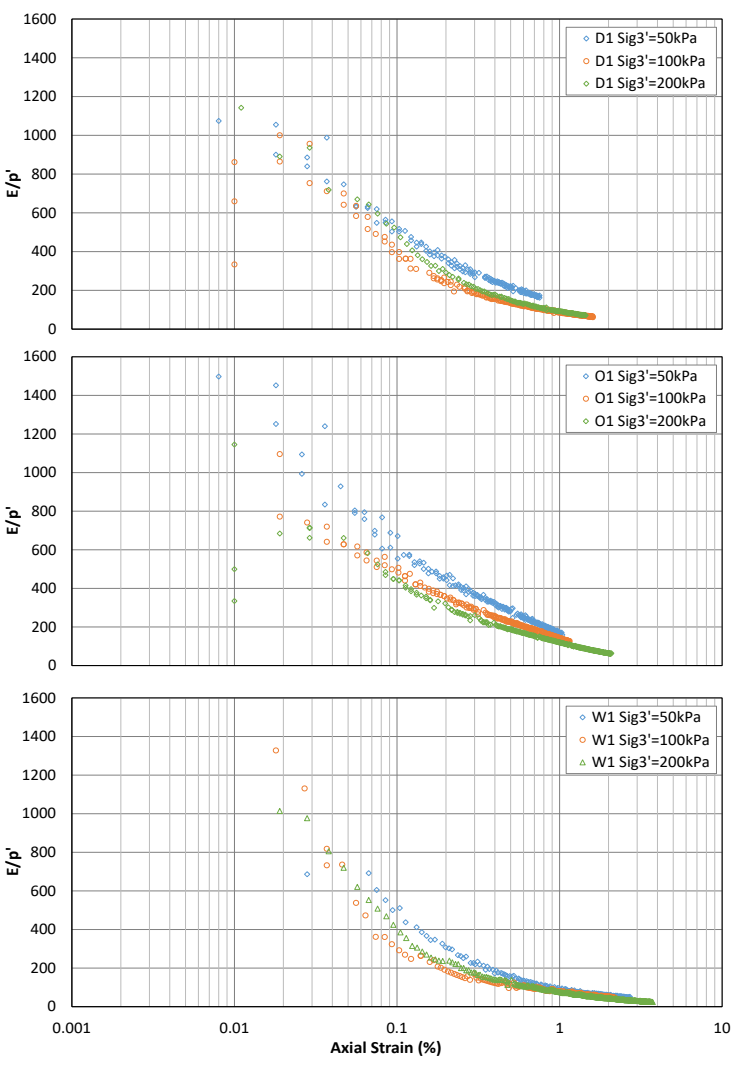

(a)
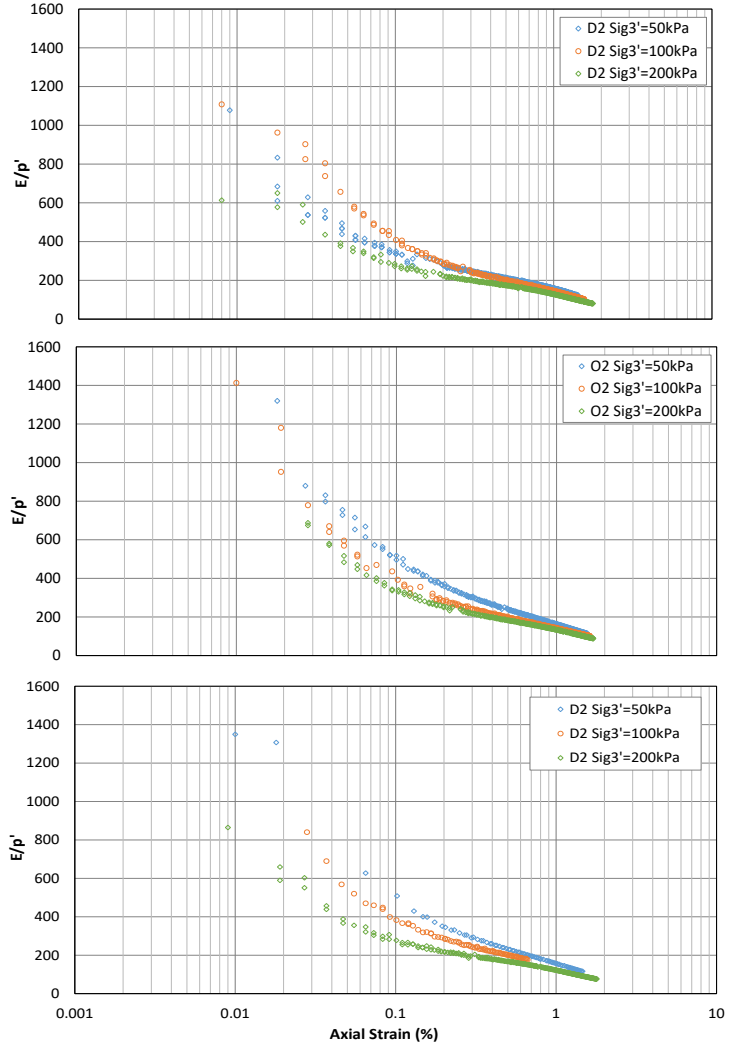

(b)

Figure 6. Normalized Young Modulus for all specimens: (a) Samples B-Mir01 (b) Samples B-Mir02

\section{CONCLUSIONS}

Two samples of Brazilian bauxite tailings obtained at the site of Miraí mine were geotechnically characterized to determine its nature. After this characterization, it was verified that there is a heterogeneity between the material that is being stored in the dam with time. This is due to the change of exploration area once the area with the desired mineral content has been exhausted. Care must be taken when trying to use this material as a construction ma-terial.

The two materials tested were identified as sandy clay (B-Mir01) collected in Feb/2016 and a non-plastic silty sand (B-Mir02) collected in Sept/2016. To determine and compare its shearstrength parameters triaxial test CAU were performed with the objective of evaluate the development of PWP. For this and based on the compaction curves, three study points were chosen. Specimens were molded at different positions along the compaction curve.

The sample B-Mir01 presented different stress paths for the three points tested. When compacting dry and wet of optimum, the material developed positive PWP to reach the failure. A singular behavior was detected in specimens compacted wet of optimum, where potential liquefaction was observed. 
The results from sample B-Mir 02 sample, suggested that the material do not present any tendency for PWP development that can induce liquefaction.

The maximum normalized secant deformability modulus $\left(\mathrm{E} / \mathrm{p}^{\prime}\right)$ presented a value of about 1200 for B-Mir01 and approximately 1000 for B-Mir02. At $0.1 \%$ the normalizes modulus presented similar values

A great variability was observed for the effective cohesion, varying from $6 \mathrm{kPa}$ to $24 \mathrm{kPa}$ for BMir01 and from $24 \mathrm{kPa}$ to $36 \mathrm{kPa}$ for B-Mir02. The friction angle varied from $25^{\circ}$ to $35^{\circ}$ for BMir01 and from $35^{\circ}$ to $39^{\circ}$ for B-Mir02.

Full characterization of any material is required to allow the use of any tailing material as construction material. This is due not only to the characteristics of the material itself, but also due to the variability that may exist according to the collection point and time. The results obtained for the two specimens presented here indicates a significant variation for shear strength data and a less variability in terms of deformability.

\section{REFERENCES}

Blight, G.E., Bentel, G.M. (1983). The behavior of mine tailings during hydraulic deposition. Journal of the South African Institute of Mining and Metallurgy. April. pp. 73 - 86.

Buchanan, S.J.; So, H.B.; Kopittke, P.M and Menzies, N.W. (2010). Influence of texture in bauxite residues on void ratio, water holding characteristics, and penetration resistance. Geoderma 158, pp. 421-426.

Fourie, A. (1988). Beaching and permeability properties of tailings. Hydraulic fill structures. GSP 21 - ASCE. pp. 142-154.

Gore, M. S. (2015). Geotechnical Characterization of Bauxite Residue (Red Mud). PhD Thesis. The University of Texas at Austin. p.287.

Gore, M.S.; Gilbert, R.B.; McMillan, I.; Isovitsch, S.L.P. (2016). Geotechnical Characterization of Compacted Bauxite Residue for Use in Levees. Published as part of proceedings of Geotechnics for Sustainable Energy - Geo-Chicago, Illinois, United States, 14-18 August 2016.

IAI (2008). Fourth sustainable bauxite mining report. International Aluminium Institute. 13p.

Klauber, C.; Gräfe, M; Power, G. (2011). Bauxite residue issues: II. options for residue utilization. Hydrometallurgy 108. pp 11-32.

MacRobert, C. J. (2012). A field study of beaching behavior and the in situ moisture regime of tailing during active deposition. MSc dissertation. University of the Witwatersrand

Nikraz, H. R.; Bodley, A. J.; Cooling, D. J., Kong, P. Y. L.; and Soomro, M. (2007). Comparison of Physical Properties between Treated and Untreated Bauxite Residue Mud. Journal of Materials in Civil En-gineering, Vol. 19, No. 1, pp. 2-9.

Pedrosa, G. J. (2012). Modelação física da disposição de rejeitos de bauxita por meio de diques.

Power, G.; Gräfe, M. and Klauber, C. (2011). Bauxite residue issues: I. Current management, disposal and storage practices. Hydrometallurgy 108, pp. 33-45.

Rachel, R. M.; Silva, F. C.; van Deursen, C. (2012). Reasons for bauxite beneficiation. The International Committee for Study of Bauxite, Alumina \& Aluminium - 30 October 2012 at ICSOBA-Belem,

Rout, S.K.; Sahoo, T.; Das, S. K. (2013). Design of tailing dam using red mud. Cent. Eur. J. Eng. 3(2). pp. 316-328. DOI: 10.2478/s13531-012-0056-7.

Van Deursen, C.M. (2016). Métodos de desaguamento e disposição de rejeito da bauxita: Estudo de caso e avaliação econômica

Villar, L. F. S.; de Campos, T.M.; Azevedo, R.F.; Zornberg, J.G. (2009). Influence of laboratory techniques on the geotechnical characterization of mining and industrial wastes. Proceedings of the 17th International Conference on Soil Mechanics and Geotechnical Engineering. M. Hamza et al. (Eds.). pp. 186-189. 